\title{
Vascular plant and cryptogam diversity in Fagus sylvatica primeval forests and comparison to production stands in the western Carpathian Mountains, Slovakia
}

\author{
Dissertation \\ zur Erlangung des mathematisch-naturwissenschaftlichen Doktorgrades \\ „Doctor rerum naturalium“ \\ der Georg-August-Universität Göttingen \\ im Promotionsprogramm \\ Biologische Diversität und Ökologie \\ der Georg-August University School of Science (GAUSS)
}

vorgelegt von

Stefan Kaufmann

aus Leoben

Göttingen, 2019 



\section{$\underline{\text { Betreuungsausschuss }}$}

Prof. Dr. Christoph Leuschner, Abteilung Pflanzenökologie und Ökossystemforschung, Universität Göttingen

Prof. Markus Hauck, Abteilung Pflanzenökologie und Ökossystemforschung, Universität Göttingen

Prof. Erwin Bergmeier, Abteilung Vegetationsanalyse und Phytodiversität, Universität Göttingen

Mitglieder der Prüfungskommission

Referent:

Prof. Dr. Christoph Leuschner, Abteilung Pflanzenökologie und Ökossystemforschung, Universität Göttingen

Korreferent:

Prof. Markus Hauck, Abteilung Pflanzenökologie und Ökossystemforschung, Universität Göttingen

\section{$\underline{\text { Weitere Mitgleider der Prüfungskomission }}$}

Prof. Dr. Hermann Behling, Abteilung Palynologie und Klimadynamik, Universität Göttingen

PD Dr. Dirk Gansert, Abteilung Pflanzenökologie und Ökossystemforschung, Universität Göttingen

Prof. Dr. Holger Kreft, Abteilung Biodiversität, Makroökologie und Biogeographie, Universität Göttingen

Tag der mündlichen Prüfung: 26.06.2018 



\section{Summary}

Conflicting evidence exists with respect to the putative effect of forest management on plant species diversity. Various published studies have concluded that primeval forests are not that species-rich and that forest management may increase species richness in certain cases. Yet, it appears that such conclusions have often been drawn from the comparison of production forests to reference forests with a management legacy, i.e. stands in which forest management ceased only a few decades ago.

The present study explores the impact of forest management on the diversity of vascular plants, bryophytes and lichens in Fagus sylvatica production forests in comparison to untouched primeval forests without any detectable management legacy in the western Carpathian Mountains, eastern Slovakia. This study in three production and three primeval forests also assesses the role of natural forest dynamics for species diversity and highlights the importance of height in the crown for the diversity and composition of epiphytic bryophyte and lichen communities.

The results demonstrate that forest management-related disturbances do not increase landscapelevel vascular plant species richness in comparison to untouched primeval forests. Even though mean plot-level diversity ( $\alpha$-diversity) was higher in the production forests, rarefaction/extrapolation showed a similarly high landscape-level vascular plant diversity $(\gamma-$ diversity) in the primeval forests. Comparing the $\gamma$-diversity of vascular plants in the initial, optimal and terminal stages with the production forests showed no significant differences between the three stages, and to the managed stands. In contrast, mean plot-level species richness of epiphytic cryptogams tended to be higher in the primeval forests. Rarefaction/extrapolation revealed an about 30 and $100 \%$ higher bryophyte and lichen species richness $(\gamma$-diversity) in the primeval forests, respectively. Comparing the epiphyte species diversity of the three stages with the production forests provided a significantly higher species richness in any stage of the forest development. Species turnover between plots ( $\beta$-diversity) was in the three systematic groups generally higher in the primeval forests, indicating a greater habitat heterogeneity and spatially more variable species composition of the communities. In addition to habitat diversity, habitat continuity is playing an essential role for maintaining a high higher species richness in the primeval forests. This is visible when comparing the epiphyte species richness on stems of a given stem diameter class between production und primeval forests. Epiphytic bryophyte and lichen diversity per stem size class was significantly higher in the primeval forests. This was attributed to the fact that trees with large diameters in 
the production stands rarely were older than 100 years, whereas the maximum age of largesized beeches in the primeval forest was over 400 years.

Natural forest dynamics affected the composition, but not the species richness, of the forest floor vegetation. Certain species showed a strong preference for either the initial, optimal or terminal stage, reflecting a high species turnover in primeval forests. Vascular species richness, however, did not differ between the three stages. In contrast to vascular plants, bryophyte and lichen species composition and richness on living trees and standing deadwood was strongly affected by natural forest dynamics. In general, epiphyte diversity increased from the initial to the terminal stage. Several bryophytes and lichens showed a distinct preference for one of the three stages, showing a close association with the ageing of trees and diameter growth. Of the detected bryophytes and lichens, 50 and $22 \%$, respectively, were significantly associated with large-diameter stems ( $\geq 70 \mathrm{~cm}$ ). Bryophytes and lichens on lying deadwood were not affected by natural forest development, as no stage differences in the species richness were detectable.

The analysis of the epiphytic bryophyte and lichen vegetation from the tree base to the crown demonstrated that sampling only the lowermost $2 \mathrm{~m}$ results in a marked underestimation of total epiphyte species richness in temperate broadleaf forests. More specifically, about $10 \%$ of the overall bryophyte and $48 \%$ of the lichen species pool would have been missed. The vertical change in the epiphytic bryophyte and lichen flora reflects the increase in light intensity, decrease in atmospheric moisture and the growing input of acids and nitrogen compounds when moving from the trunk base to the canopy. The vertical change in microclimate and microsite conditions also leads to distinct compositional variations of both studied groups along the height gradient.

This study clearly shows that forest management markedly reduces overall plant diversity and strongly impacts on the species composition in managed forests in comparison to untouched primeval forests. The higher plant species richness in primeval forests is mainly due to the much longer habitat continuity and greater habitat heterogeneity in horizontal and vertical direction, as generated by the processes of natural forest development. The disappearance of the terminal stage of forest development and a principal reduction in forest structural heterogeneity in production forests promote the loss of many plant species with close association to primeval forest attributes. Protecting the last remaining temperate primeval forests is thus an important element of a global strategy to conserve the biodiversity on earth. 


\section{TABle of Contents}

\section{CHAPTER 1}

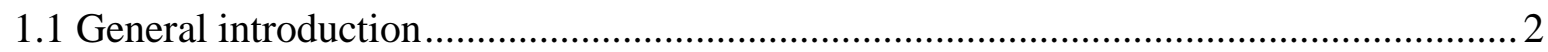

1.2 Species diversity in primeval compared to production forests ....................................... 3

1.3 Natural forest dynamics in boreal and temperate forests ................................................ 4

1.4 Vertical heterogeneity along tree height gradients .................................................... 6

1.5 Study objectives and hypothesis ...........................................................................

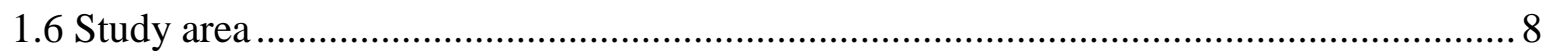

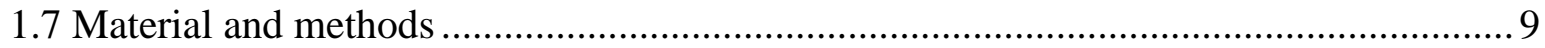

\section{CHAPTER 2}

Comparing the plant diversity of paired beech primeval and production forests:

Management reduces cryptogam, but not vascular plant species richness..

\section{CHAPTER 3}

Effects of natural forest dynamics on vascular plant, bryophyte, and lichen diversity in primeval Fagus sylvatica forests and comparison with production forests

\section{CHAPTER 4}

Vertical variation in epiphytic cryptogam species richness and composition in a primeval Fagus sylvatica forest.

\section{CHAPTER 5}

Synopsis

5.1 Impact of forest management-related disturbances on species diversity 141

5.2. Habitat heterogeneity and continuity promote species richness 143

5.3 The role of natural forest dynamics for plant diversity and composition 144

5.4 Overlooked cryptogam diversity along the vertical tree gradient.

5.5 Conclusion

Index of tables 150

Index of figures 152

Acknowledgments 156

Publications 157

Presentations. 

Chapter 1

General introduction 


\subsection{General introduction}

Human intervention has greatly decreased the area of natural ecosystems worldwide, of which forests are in particular affected (Hannah et al. 1995; Pearce 2001). Ball (2001) reported a considerable decrease of forest cover from $50 \%$ of the earth's surface before early civilizations to less than $30 \%$ today. The conversion to agriculture and clearing have resulted in a loss of 7 to 11 million $\mathrm{km}^{2}$ during the last 300 years (FAO 2018) and have been reported as main drivers for the loss of forests in the boreal, temperate and the tropical biomes (Hansen et al. 2010). Today, more than $40 \%$ of the terrestrial surface is agricultural land, including pastures and grasslands (Turner et al. 2007) and a projected growth of the world population to 9 billion in 2050 (Bongaarts 2009) may further increase forest clearance in order to meet the global food demand and to enable urbanization (Tilman et al. 2001).

Deforestation, however, may have serious impacts on ecosystem functioning worldwide. It affects the hydrological cycle by reducing precipitation and evapotranspiration (Werth \& Avissar 2002; Rudel et al. 2005). It also influences regional and global climate by the release of carbon stored in plants and soils, and by the alteration of soil properties in terms of aggregation, which decreases rainfall infiltration resulting in an increased runoff (Costa \& Foley 2000; Lawton et al. 2001; Bala et al. 2007).

Forest clearance for industrial purposes is not the only threat to the world's natural forest ecosystems. Of the remaining forest stands, only a small fraction has remained in a natural state. In the boreal and temperate biomes, natural forests make up only $1 \%$ of European forests, whereas the proportion in the United States and Canada accounts $13 \%$ and 40-52\%, respectively (Heywood \& Watson 1995; Parviainen et al. 2000). Forest management such as logging, drainage and litter extraction as well as changes in pristine tree species composition and plantation of monocultures alters stand structural properties and the ecological environment (Graae \& Heskjær 1997; Bengtsson et al. 2000; Kaplan et al. 2009), which further causes the loss of natural forest features and structures. From this follows that human intervention not only affects ecosystem functioning through modification of the physical environment, but also plant diversity and composition.

Natural forest ecosystems support more than half of all known species on earth (Olson et al. 1998), and tropical forests exhibit the highest biodiversity of all terrestrial ecosystems (Wright 1999). While plant species richness of boreal and temperate forests does not match that of tropical forests, their species composition is nonetheless remarkable. However, intensive forest management has turned most boreal and temperate forests into production stands (Bryant et al. 
1997; Hanski 2005), thus exacerbating the loss of native plant species through habitat destruction and alteration and the introduction of invasive species (Gilliam 2007). The continuing decline in species diversity that has confronted our world over the past decades (Butchart et al. 2010; Hooper et al. 2012) is an issue of growing concern, as it is reported to decrease ecosystem functioning and services (Isbell et al. 2011). Therefore, the conservation of natural forests is of prime importance because they are considered as a reference system for sustainable forest management (Wesołowski 2005), which is important to halt the loss of species diversity (Parviainen et al. 2007).

\subsection{Species diversity in primeval compared to production forests}

For several years, there has been an ongoing discussion about the effects of forestry on species diversity and composition, including the question whether forest management may not even increase plant species richness compared to untouched primeval forests. In contrast to managed stands, which are primarily affected by anthropogenic disturbances such as logging and other forest management activities, forest fires, windthrow and insect infestations are the predominant disturbances in primeval forests (Kaplan et al. 2009). Disturbance events, however, are not necessarily negative for diversity. They create habitats for additional species to colonize, which may increase overall diversity, although the disturbance intensity determines whether species richness increases or not. The 'intermediate disturbance hypothesis' formulated by Connell in 1978 states that species richness should be highest at intermediate disturbance levels due to the co-occurrence of both rapid colonizers and more competitive species (Townsend \& Scarsbrook 1997). This suggests that moderate disturbance, e.g. the extraction of single trees or groups through modern forest management, increases plant species richness, perhaps even such that it exceeds that of primeval forests. However, in order to answer this question raised in the beginning, comparing species diversity patterns between production forests of different management intensities and former managed stands several years after abandonment is not a suitable approach, as management legacies may last for centuries (Freschet et al. 2013; von Oheimb et al. 2014), and wrong conclusions may be drawn. More meaningful is the comparison of production stands with untouched primeval forests, in which the effects of natural disturbances can be compared to the impact of forest management related disturbances on stand structure, plant diversity and composition.

In tropical forests, there are several studies dealing with this issue. A meta-analysis comprising 138 studies by Gibson et al. (2011) compared species diversity values between primeval and 
anthropogenically disturbed forests. Their results indicated a substantially lower biodiversity in degraded stands and highlighted the outstanding value of primeval forests in maintaining tropical biodiversity. This was also confirmed by Barlow et al. (2007) for 15 taxonomic groups in primary, secondary and plantation forests. Additionally, individual studies for vascular epiphytes in the Venezuelan Andes (Barthlott et al. 2001) and tree diversity in Singapore and Sulawesi (Turner et al. 1997 and Kessler et al. 2005) found the same pattern, i.e. higher species richness in primary compared to secondary and plantation forests.

In the boreal and temperate biomes, numerous studies also assessed species diversity differences between both forest types. However, most of the forests designated as unmanaged were affected by different forest management practices and intensities in the past. An overview of this topic is given by Paillet et al. (2010) in their meta-analysis encompassing 120 individual comparisons of species diversity between unmanaged and managed forests throughout temperate and boreal Europe. One important finding of this study was that species richness was slightly higher in unmanaged forests, though, even the response within individual taxa was not uniform. There are also individual studies comparing the species richness between both forest types for the understory vegetation (e.g. Graae \& Heskjær 1997; Brunet et al. 1996), epiphytic bryophytes and lichens (e.g. Dettki \& Essien 1998; Vellak \& Ingerpuu 2005; Friedel et al. 2006) and wood-inhabiting fungi (Stokland \& Larsson 2011), of which all unmanaged forests studied were formerly affected by forestry. For this reason, comparative analyses between true primeval and adjacent production forests are lacking in Europe so far and have only been conducted in boreal and temperate forests of North America (e.g. Lesica et al. 1991; Halpern \& Spies 1995; Scheller \& Mladenoff 2002; Desponts et al. 2004).

\subsection{Natural forest dynamics in boreal and temperate forests}

Intensive forest management has strongly suppressed the irregular occurrence of natural disturbance dynamics in production forests. This has been replaced by regular anthropogenic disturbances such as thinning, clearcutting and replanting (Schelhaas et al. 2003), which cause a distinct limitation of primeval forest attributes in young, second-growth and managed stands (Spies et al. 1988; Bengtsson et al. 2000). Natural disturbance strongly influences forest structure, composition and functioning (Franklin et al. 2002). Disturbance events like stand break-up, insect infestations or age-related tree mortality (Brunet et al. 2010), contribute to the great structural heterogeneity of primeval forests by providing more niches and diverse environmental conditions (Bazzaz 1975), which in turn may increase species diversity of 
vascular plants (e.g. Halpern \& Spies 1995; Hong et al. 1997), bryophytes and lichens (e.g. Ódor \& Standovár 2001; Brunialti et al. 2010). In order to illustrate the temporal dynamics of primeval forest stand development, most researchers split up the continuous forest dynamic process of tree aging and structural change into distinct development stages (e.g. initial, optimal and terminal stages; Leibundgut 1993; Korpel 1995; Meyer 1999), which can be considered as equivalents to the growth phases in production stands (Král et al. 2010). However, managed stands are typically compared to primeval forest conditions without taking into account the role of natural disturbance on species diversity and composition. For this reason, Roberts and Gilliam (1995) suggest that comparing different succession stages in production stands with the equivalents in primeval forests would provide much clearer insights of management impacts on stand structure, species diversity and composition. There are several studies dealing with the effects of natural forest dynamics on stand structure and biodiversity in boreal (e.g. Kuuluvainen 2002; Grandpré et al. 2003; Kuuluvainen \& Aakala 2011) and temperate forests (e.g. Emborg et al. 2000; Dittrich et al. 2013; Roberts \& Gilliam 2014). However, until now there have been no comparative analyses between individual stages of natural forest development and adjacent production forests.

Structure and composition of the overstory trees strongly affect the amount of resources that reach the understory (Barbier et al. 2007). Microclimatic factors such as light, air humidity, soil moisture and temperature as well as chemical soil properties are controlled by the overstory and thus determine species diversity and composition of the herbaceous layer (Leuschner \& Lendzion 2009; Ellenberg \& Leuschner 2010; Gilliam \& Roberts 2014). Compared to production forests with rather homogeneous habitat structures, primeval forests show a wide stem diameter distribution (Commarmot et al. 2005) and consist of a multilayered canopy and small-scaled patchy structures of trees differing in age (Korpel 1995). These spatially more heterogeneous conditions account for a diverse microclimate on a very small scale, which in turn may favour a higher vascular plant diversity. Beside microclimate and edaphic factors, which are important for both understory vegetation and cryptogams (Beatty 2014; Hauck 2011), the availability of suitable substrates is in particular important for the occurrence of epiphytic bryophytes and lichens. Old trees and large stem diameters (Friedel et al. 2006; Fritz et al. 2009; Ódor et al. 2013), which are virtually absent from production forests due to a given rotation period, provide more time for colonization and a broad range of microhabitats. Additionally, the occurrence of coarse woody debris as a consequence of natural disturbance (Spies et al. 1988) and deadwood in different decay stages (Fritz et al. 2009a, b; Ódor et al. 2005, 2006) further contribute to complex habitat structures in primeval forests, which increase species 
richness of epiphytic cryptogams. Especially deadwood is an important component of primeval forests, as the deadwood legacy of advanced stages bridges the lack of microsites in early stages of the natural forest development and favours colonization of epiphytic bryophytes and lichens (Dittrich et al. 2013). However, this situation is extremely rare in production forests due to the harvesting of trees before senescence and the removal of deadwood (Standovár 2003).

\subsection{Vertical heterogeneity along tree height gradients}

Primeval forests are not only characterized by a high horizontal heterogeneity. The vertical complexity, i.e. along the gradient from the tree base to the crown provides diverse microsites exposed to different environmental conditions for epiphytic bryophytes and lichens. Barkman (1958) and Parker (1995) described a vertical microclimatic gradient of light intensity and wind speed along trees in addition to changes in temperature and air humidity (Campbell \& Coxson 2001, Leuschner \& Ellenberg 2017), which strongly affect species richness and composition. Nevertheless, in the context of biodiversity assessments of epiphytic cryptogams, most surveys are restricted to the lowermost $2 \mathrm{~m}$ on the stem (e.g. Hauck et al. 2002; Friedel et al. 2006). This is due to the fact that the detection of bryophytes and lichens above that height is usually time-consuming and even expensive, if professional tree-climbers or technical equipment like cranes are required (e.g. Boch et al. 2013; Lakatos \& Fischer-Pardow 2013). It must therefore be assumed that epiphyte species richness in forests is severely underestimated when sampling only the stem base (0-2 m). Changing microsite and environmental conditions along a vertical gradient may favour the occurrence of species adapted to different ecological niches compared to those prevailing at the stem base.

In tropical forests, there are several studies focusing on the vertical distribution of vascular epiphytes on tree stems (e.g. Nieder et al. 2000; Krömer et al. 2007). However, the number of studies on epiphytic cryptogams is quite manageable, both regarding studies from the temperate zone (e.g. Jarman \& Kantvilas 1995 from Tasmania; McCune et al. 1997 and Sillett \& Rambo 2000 from the Pacific Northwest of North America) and the tropics (Goda-Sporn et al. 2010). In boreal and temperate Europe, existing studies were all conducted in managed stands or on solitary trees in open habitats (Boch et al. 2013; Fritz 2009; Kiebacher et al. 2016; Marmor et al. 2013). Surveys in primeval forests are lacking but needed to reveal potential effects of forest management on the vertical distribution of epiphytic bryophytes and lichens. 


\subsection{Study objectives and hypothesis}

With the overall aim to understand the effects of forest management-related disturbance in comparison with natural disturbance, the present thesis deals with the species diversity and composition of vascular plants, bryophytes and lichens in three Fagus sylvatica primeval/production forest pairs in eastern Central Europe. Furthermore, it also addresses the question whether cryptogam diversity in forests is severely underestimated, if only the lowermost part of trees is sampled. During the fieldwork from 2013 to 2015, I investigated the forest floor vegetation and the epiphyte species richness in primeval forests and compared the diversity pattern with adjacent production stands (Chapter 2). Besides, I studied the influence of natural forest dynamics in primeval forests on species richness and composition and compared the diversity pattern of each assigned development stage to production stands (Chapter 3). Additionally, a storm event in 2014, which uprooted almost all trees on an area of 8 ha, provided the unique opportunity to investigate species distribution of epiphytic bryophytes and lichens along a height gradient of formerly standing trees (Chapter 4). The results of this thesis should provide new insights about the value of primeval forests in conserving native plant diversity compared to production forests. In addition, they should also reveal the role of natural forest dynamics for the species richness and composition of vascular plants and epiphytic cryptogams compared to management-related disturbances. Furthermore, this investigation should highlight the importance of spatial habitat heterogeneity for vascular plant and cryptogam diversity.

The overall hypotheses were:

1) Forest management-related disturbance increase the species richness of vascular plants but not that of epiphytic bryophytes and lichens.

2) Vascular plant and epiphyte species richness is higher in any forest development stage than in the production stands.

3) The between-plot species turnover of vascular plants, bryophytes and lichens is higher in primeval forests reflecting the high spatial heterogeneity.

4) Natural forest dynamics affect species richness and composition of the forest floor and epiphyte vegetation.

5) Biodiversity surveys limited to the stem base would lead to a substantial underestimation of the total lichen than bryophyte species richness. 
6) The epiphyte vegetation indicates a darker and moister microclimate towards the stem base and an increasing acidity of the bark and nitrogen availability towards the crown.

\subsection{Study area}

The study was conducted in the western Carpathian Mountains in eastern Slovakia, where some remnants of Fagus sylvatica primeval forests have survived clearing and conversion to production forests (Fig. 1.1). These remnants have recently been included in the UNESCO`s World Heritage List as the "Primeval beech forests of the Carpathians". Three forests were selected for this study, namely Havešová, Stužica (both located in the Poloniny National Park) and Kyjov (in the Vihorlat Protected Landscape Area). According to Kucbel et al. (2012), no human intervention has ever taken place in any of these forests, which is also supported by regional management plans indicating no management for a long period before the enforcement of legal protection.

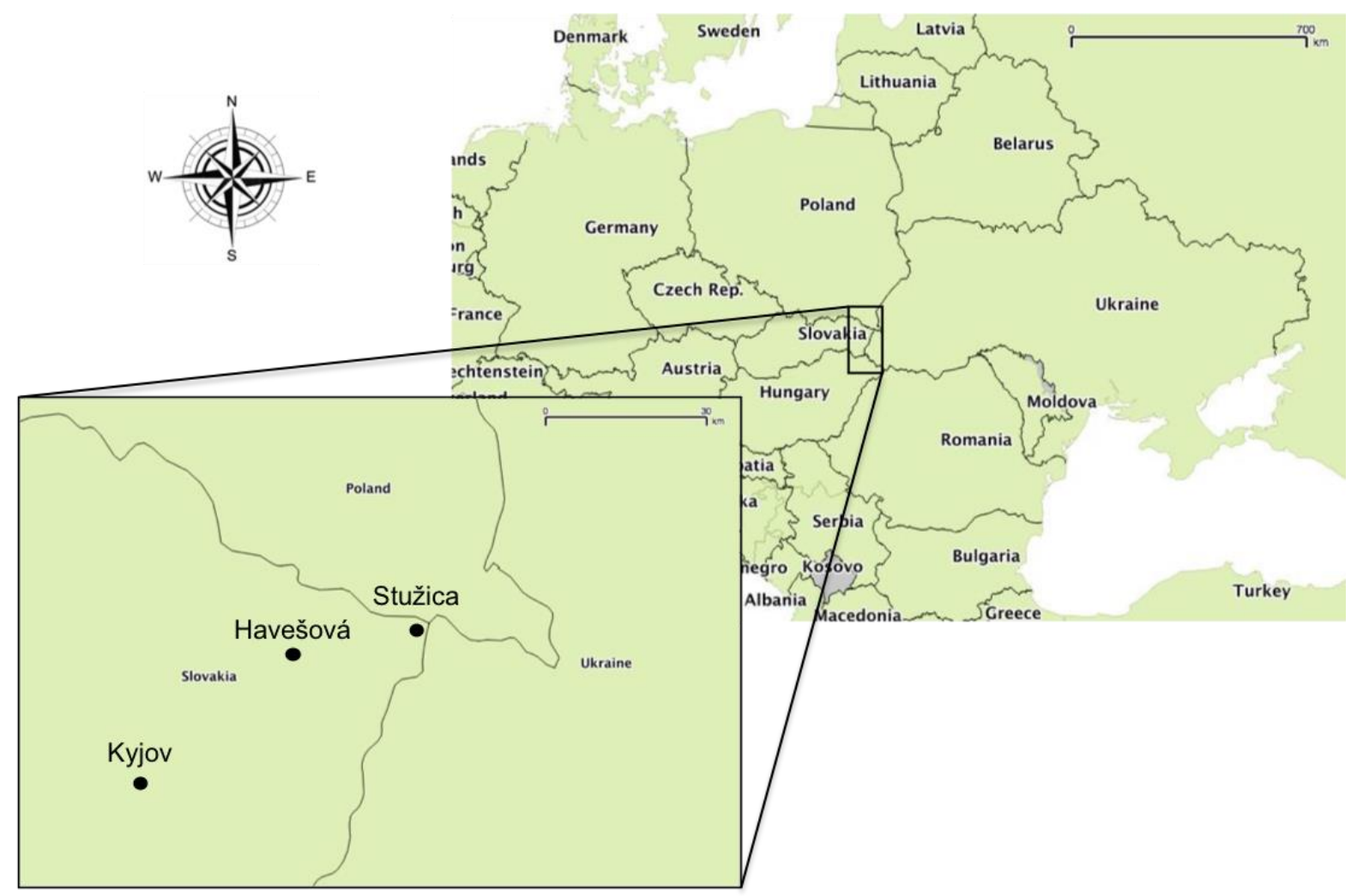

Figure 1.1. Location of the three study sites Havešová, Kyjov and Stužica in the western Carpathian Mountains, eastern Slovakia.

Within a distance of $1 \mathrm{~km}$ to the primeval forests, three beech production forests were selected in Havešová, Kyjov and Stužica in order to guarantee comparable climatic and edaphic site 
conditions between both forest types. The production stands varied between 90 and 100 years (Havešová and Kyjov) or 70-100 years (Stužica) and were managed in a shelterwood cutting system with two cuts conducted within 10 years at the end of the production cycle, while no or few management activities are conducted during the first 80-90 years. For this reason, these stands were expected to show the highest similarity to the primeval forests, as there has been no human intervention for a long period.

Table 1.1. Physiographic characteristics of the three primeval forest sites in eastern Slovakia. The conditions in the nearby production stands are very similar ${ }^{\mathrm{a}}$.

\begin{tabular}{lccc}
\hline & Havešová & Kyjov & Stužica \\
\hline Elevation (m a.s.l.) & $550-650$ & $700-820$ & $700-950$ \\
Mean annual precipitation $\left(\mathrm{mm} \mathrm{yr}^{-1}\right)$ & $800-850$ & $950-1000$ & $900-1200$ \\
Mean annual temperature $\left({ }^{\circ} \mathrm{C}\right)$ & $6.0-6.5$ & $5.2-5.7$ & $4.0-5.0$ \\
Geology & Carpathian Flysh & Andesite & Carpathian Flysh \\
Soil type & Eutric Cambisol & Dystric Cambisol & Eutric Cambisol \\
Aspect & S-SW & N-NE & S \\
\hline
\end{tabular}

${ }^{\mathrm{a} D a t a}$ after Korpel (1995).

All six forest stands were located at sub-montane to montane elevation (500-950 $\mathrm{m}$ a.s.1.), thus differing in mean annual precipitation and temperature (Table 1.1). Due to differences in bedrock (andesite vs. flysh), the soils in Kyjov (Dystric Cambisols) were nutrient-poorer than those in Havešová and Stužica (Eutric Cambisols; Vološčuk 2014). The forests in Kyjov grew predominantly on north-facing slopes, while south-facing slopes dominated in Havešová and Stužica.

\subsection{Material and methods}

\section{Study design}

The same plot design was used for Chapters 2 and 3. Forty circular plots of $500 \mathrm{~m}^{2}$ were established in each primeval forest in systematic grids with a mesh size of 140 m (Havešová), $100 \mathrm{~m}$ (Stužica) or $64 \mathrm{~m}$ (Kyjov) as a minimum distance between neighbouring plot centres. In contrast, ten plots were selected in the adjacent production stands in the same way as described above. However, due to relative small sample size of the production forests, $50 \mathrm{~m}$ was the maximum possible distance between the plot centres in these stands. In Chapter 3, each sampling unit in the primeval forests was additionally assigned to one forest development stage, 
i.e. initial, optimal and terminal stage. The classification followed Feldmann et al. (2018) and allows the co-occurrence of the three stages within a sampling unit.

I sampled all forest floor (including terricolous bryophytes) and woody species as well as epiphytic bryophytes and lichens that occurred strictly within the $500 \mathrm{~m}^{2}$ plots and estimated the cover of the individual species by using cover classes. I sampled epiphytic cryptogams only on trees (living, standing and downed deadwood) with a minimum dbh (diameter at breast height) of $\geq 15 \mathrm{~cm}$.

In Chapter 4, a systematic grid with a mesh size of $40 \mathrm{~m}$ as minimum distance between neighbouring plot centres was established in the windthrow area and ten circular plots of 500 $\mathrm{m}^{2}$ were then randomly selected for the investigations. Epiphytic bryophytes and lichens were only sampled on trees with a $\mathrm{dbh}>10 \mathrm{~cm}$ and that were uprooted during the storm event in 2014. Older deadwood was not taken into consideration. Epiphyte sampling along the stem followed widely Fritz (2009). Each tree trunk was divided into $2 \mathrm{~m}$-segments from the stem base up to the insertion of the crown. The crown with all branches and twigs was divided into the inner and outer crown (Fig. 1.2). In total, 57 trees were sampled. Bryophyte and lichen species were recorded for the individual segments (up to 13 segments) and the two crown regions by using presence-absence values.

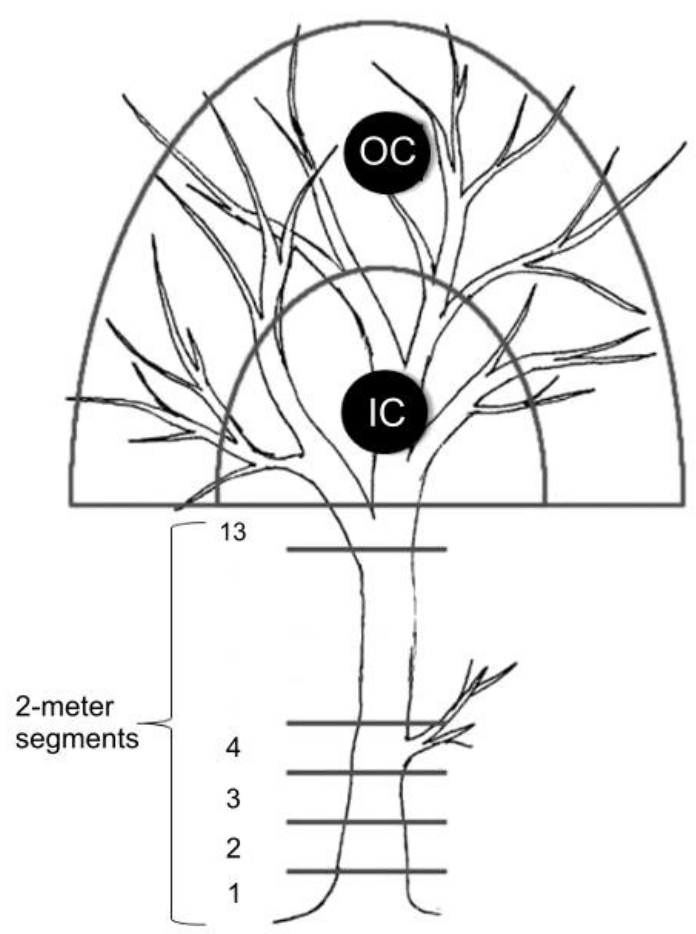

Figure 1.2. Scheme illustrating the sampling design (Chapter 4) applied for the assessment of epiphytic bryophytes and lichens on beech trees with up to 13 segments of each 2 m length. IC and OC stand for the inner and outer crown. 


\section{Data analysis}

For the comparison of the vascular plant, bryophyte and lichen species richness between primeval and production forests (Chapter 2), I pooled the data of the three study sites Havešová, Kyjov and Stužica in order to make a general statement. However, I also analysed each study site separately. I performed rarefaction and extrapolation to compare the species richness of each taxonomic group by using species incidence frequencies. This method is well appropriate to compare the diversity between unequal sample sizes with reliable statistical inference. Additionally, I calculated the species turnover ( $\beta$-diversity) as a measure for habitat heterogeneity in both primeval and production forest by using the Sørensen dissimilarity index (SDI). Furthermore, I performed a non-metric-multidimensional scaling (NMDS) to detect species preferences with regard to the forest type.

In Chapter 3, again I used rarefaction and extrapolation (see above) to compare the species richness of the ground vegetation and epiphytic bryophytes and lichens between each forest development stage (initial, optimal and terminal) and the corresponding production stands. The species data were pooled over the three study sites. I applied a canonical correspondence analysis (CCA) to identify preferences of individual plant, bryophyte and lichen species for the three forest development stages. In addition to that, I conducted an indicator species analysis (ISA) to detect significant associations of epiphytic bryophytes and lichens with different stem diameter classes in the primeval forests. Finally, in order to detect effects of stem diameter on epiphyte species richness in primeval and production forests, I applied a generalized linear model (GLM).

In Chapter 4, I used updated Ellenberg indicator values (EIV) of light (L), moisture (F), temperature $(\mathrm{T})$, acidity $(\mathrm{R})$ and nitrogen $(\mathrm{N})$ for bryophytes and lichens to gain an impression about microclimate and microsite conditions prevailing along the vertical gradient of trees. Additionally, I applied generalized linear mixed effects models (GLMM) to analyse the effect of height above the ground on the species richness of epiphytic bryophytes and lichens. I also used non-metric multidimensional scaling (NMDS) to identify gradients in species composition along the vertical gradient. 


\section{References}

Aragón, G., Martínez, I., Izquierdo, P., Belinchón, R. \& Escudero, A. (2010). Effects of forest management on epiphytic lichen diversity in Mediterranean forests. Applied Vegetation Science, 13(2), 183-194.

Bala, G., Caldeira, K., Wickett, M., Phillips, T.J., Lobell, D.B., Delire, C. \& Mirin, A. (2007). Combined climate and carbon-cycle effects of large-scale deforestation. Proceedings of the National Academy of Sciences, 104, 6550-6555.

Ball, J.B. (2001). Global forest resources: history and dynamics. The Forests Handbook, Volume 1: An Overview of Forest Science, 3-22.

Barbier, S., Gosselin, F. \& Balandier, P. (2008). Influence of tree species on understory vegetation diversity and mechanisms involved-A critical review for temperate and boreal forests. Forest Ecology and Management, 254(1), 1-15.

Barkman, J.J. (1958). Phytosociology and ecology of cryptogamic epiphytes, including a taxonomic survey and description of their vegetation units in Europe. Van Gorcum \& Comp, Assen.

Barlow, J., Gardner, T.A., Araujo, I.S., Avila-Pires, T.C., Bonaldo, A.B., Costa, J.E., Esposito, M.C., Ferreira, L.V., Hawes, J., Hernandez, M.I.M., Hoogmoed, M.S., Leite, R.N., LoMan-Hung, N.F., Malcolm, J.R., Martins, M.B., Mestre, L.A.M., Miranda-Santos, R., Nunes-Gutjahr, A.L., Overal, W.L., Parry, L., Peters, S.L., Ribeiro-Junior, M.A., da Silva, M.N.F., da Silva Motta, C. \& Peres, C.A. (2007). Quantifying the biodiversity value of tropical primary, secondary, and plantation forests. Proceedings of the National Academy of Sciences, 104, 18555-18560.

Barthlott, W., Schmit-Neuerburg, V., Nieder, J. \& Engwald, S. (2001). Diversity and abundance of vascular epiphytes: a comparison of secondary vegetation and primary montane rain forest in the Venezuelan Andes. Plant Ecology, 152, 145-156.

Bazzaz, F.A. (1975). Plant species diversity in old-field successional ecosystems in southern Illinoi. Ecology, 56, 485-488.

Beatty, S. (2014). Habitat heterogeneity and maintenance of species in understory communities. In: Gilliam, F.S. (Ed.) The Herbaceous Layer in Forests of Eastern North America. $2^{\text {nd }}$ Edition, Oxford University Press, Oxford. 
Bengtsson, J., Nilsson, S.G., Franc, A. \& Menozzi, P. (2000). Biodiversity, disturbances, ecosystem function and management of European forests. Forest Ecology and Management, 132, 39-50.

Boch S., Müller, J., Prati, D., Blaser, S. \& Fischer, M. (2013). Up in the tree- the overlooked richness of bryophytes and lichens in tree crowns. PLoS One.

Bongaarts, J. (2009). Human population growth and the demographic transition. Philosophical Transactions of the Royal Society B, 364, 2985-2990.

Brunet, J., Falkengren-Grerup, U. \& Tyler, G. (1996). Herb layer vegetation of south Swedish beech and oak forests - Effects of management and soil acidity during one decade. Forest Ecology and Management, 88, 259-272.

Brunet, J., Fritz, Ö. \& Richnau, G. (2010). Biodiversity in European beech forests - a review with recommendations for sustainable forest management. Ecological Bulletins, 18, 77 94.

Brunialti, G., Frati, L., Aleffi, M., Marignani, M., Rosati, L., Burrascano, S. \& Ravera, S. (2010). Lichens and bryophytes as indicators of old-growth features in Mediterranean forests. Plant Biosystems, 144(1), 221-233.

Bryant, D.G., Nielsen, D. \& Tangley, L. (1997). The last frontier forests: ecosystems \& economies on the edge: what is the status of the world's remaining large, natural forest ecosystems? World Resources Institute, Forest Frontiers Initiative, Washington, DC.

Butchart, S.H.M., Walpole, M., Collen, B., van Strien, A., Scharlemann, J.P.W., Almond, R.E.A., Baillie, J.E.M., Bomhard, B., Brown, C., Bruno, J., Carpenter, K.E., Carr, G.M., Chanson, J., Chenery, A.M., Csirke, J., Davidson, N.C., Dentener, F., Foster, M., Galli, A., Galloway, J.N., Genovesi, P., Gregory, R.D., Hockings, M., Kapos, V., Lamarque, J.F., Leverington, F., Loh, J., McGeoch, M.A., McRae, L., Minasyan, A., Morcillo, M.H., Oldfield, T.E.E., Pauly, D., Quader, S., Revenga, C., Sauer, J.R., Skolnik, B., Spear, D., Stanwell-Smith, D., Stuart, S.N., Symes, A., Tierney, M., Tyrrell, T.D., Vie, J.-C. \& Watson, R. (2010). Global Biodiversity: Indicators of Recent Declines. Science, 328, 1164-1168.

Campbell, J. \& Coxson, D.S. (2001). Canopy microclimate and arboreal lichen loading in subalpine spruce-fir forest. Canadian Journal of Botany, 79, 537-555. 
Commarmot, B., Bachofen, H., Bundziak, Y. \& Bürgi, A. (2005). Structures of virgin and managed beech forests in Uholka (Ukraine) and Sihlwald (Switzerland): a comparative study. Forest Snow and Landscape Research, 79, 45-56.

Costa, M.H. \& Foley, J.A. (2000). Combined Effects of Deforestation and Doubled Atmospheric CO 2 Concentrations on the Climate of Amazonia. Journal of Climate, 13, $18-34$.

de Grandpré, L., Bergeron, Y., Nguyen, T., Boudreault, C. Grondin, P. (2014). Composition and dynamics of the understory vegetation in the boreal forest of Quebec. In: Gilliam, F.S. (Ed.) The Herbaceous Layer in Forests of Eastern North America. $2^{\text {nd }}$ Edition, Oxford University Press, Oxford.

Desponts, M., Brunet, G., Bélanger, L. \& Bouchard, M. (2004). The eastern boreal old-growth balsam fir forest: a distinct ecosystem. Canadian Journal of Botany, 82, 830-849.

Dettki, H. \& Essien, P.-A. (1998). Epiphytic Macrolichens in Managed and Natural Forest Landscapes: A Comparison at Two Spatial Scales. Ecography, 21, 613-624.

Dittrich, S., Hauck, M., Jacob, M., Rommerskirchen, A. \& Leuschner, C. (2013). Response of ground vegetation and epiphyte diversity to natural age dynamics in a Central European mountain spruce forest. Journal of Vegetation Science, 24(4), 675-687.

Ellenberg, H. \& Leuschner, C. (2010). Vegetation Mitteleuropas mit den Alpen in ökologischer, dynamischer und historischer Sicht, 6th edn. Ulmer, Stuttgart.

Emborg, J., Christensen, M. \& Heilmann-Clausen, J. (2000). The structural dynamics of Suserup Skov, a near-natural temperate deciduous forest in Denmark. Forest Ecology and Management, 126(2), 173-189.

FAO (2018). FAOSTAT Forestry Database. Available from: http://faostat.fao.org. United Nations Food and Agriculture Organization (FAO), Rome.

Feldmann, E., Glatthorn, J., Hauck, M. \& Leuschner, C. (2018). A novel empirical approach for determining the extension of forest development stages in temperate old-growth forests. European Journal of Forest Research, 1-15.

Franklin, J.F., Spies, T.A., Pelt, R.V., Carey, A.B., Thornburgh, D.A., Berg, D.R., ... Chen, J. (2002). Disturbances and structural development of natural forest ecosystems with silvicultural implications, using Douglas-fir forests as an example. Forest Ecology and Management, 155(1-3), 399-423. 
Friedel, A., v. Oheimb, G., Dengler, J. \& Härdtle, W. (2006). Species diversity and species composition of epiphytic bryophytes and lichens - a comparison of managed and unmanaged beech forests in NE Germany. Feddes Repertorium, 117(1-2), 172-185.

Fritz, Ö. (2009). Vertical distribution of epiphytic bryophytes and lichens emphasizes the importance of old beeches in conservation. Biodiversity and Conservation, 18, 289-304.

Fritz, Ö., Brunet, J., \& Caldiz, M. (2009a). Interacting effects of tree characteristics on the occurrence of rare epiphytes in a Swedish beech forest area. The Bryologist, 112, 488505 .

Fritz, Ö., Niklasson, M., \& Churski, M. (2009b). Tree age is a key factor for the conservation of epiphytic lichens and bryophytes in beech forests. Applied Vegetation Science, 12, 93106.

Gibson, L., Lee, T.M., Koh, L.P., Brook, B.W., Gardner, T.A., Barlow, J., Peres, C.A., Bradshaw, C.J.A., Laurance, W.F., Lovejoy, T.E. \& Sodhi, N.S. (2011). Primary forests are irreplaceable for sustaining tropical biodiversity. Nature, 478, 378-381.

Gilliam, F.S. (2007). The ecological significance of the herbaceous layer in temperate forest ecosystems. BioScience, 10, 845-858.

Gilliam, F.S. \& Roberts, M.R. (2014). Interactions between the berbaceous layer and overstory canopy of eastern forests. In: Gilliam, F.S. (Ed.) The Herbaceous Layer in Forests of Eastern North America. $2^{\text {nd }}$ Edition, Oxford University Press, Oxford.

Goda-Sporn, S., Bos, M.M., Kessler, M. \& Gradstein, S.R. 2010. Vertical distribution of epiphytic bryophytes in an Indonesian rainforest. Biodiversity and Conservation, 19: 745760.

Graae, B.J. \& Heskjær, V.S. (1997). A comparison of understorey vegetation between untouched and managed deciduous forest in Denmark. Forest Ecology and Management, 96, 111-123.

Halpern, C.B. \& Spies, T.A. (1995). Plant species diversity in natural and managed forests of the Pacific Northwest. Ecological Applications, 5, 913-934.

Hannah, L., Carr, J.L. \& Lankerani, A. (1995). Human disturbance and natural habitat: a biom level analysis of a global data set. Biodiversity \& Conservation, 4, 128-155.

Hansen, M.C., Stehman, S.V. \& Potapov, P.V. (2010). Quantification of global gross forest cover loss. Proceedings of the National Academy of Sciences, 107, 8650-8655. 
Hanski, I. (2005). Landscape fragmentation, biodiversity loss and the societal response. EMBO Reports, 6, 388-392.

Hauck, M. (2011). Site factors controlling epiphytic lichen abundance in northern coniferous forests. Flora, 206(2), 81-90.

Heywood, V.H. \& Watson, R.T. (1995). Global biodiversity assessment. Cambridge University Press, Cambridge, United Kingdom.

Hong, Q., Karel, K. \& Bela, S. (1997). Diversity of the understory vascular plant vegetation in 40-year old and old-growth forest stands on Vancouver Island, British Columbia. Journal of Vegetation Science, 8, 773-780.

Hooper, D.U., Adair, E.C., Cardinale, B.J., Byrnes, J.E.K., Hungate, B.A., Matulich, K.L., Gonzalez, A., Duffy, J.E., Gamfeldt, L. \& O’Connor, M.I. (2012). A global synthesis reveals biodiversity loss as a major driver of ecosystem change. Nature, 486, 105-108.

Isbell, F., Calcagno, V., Hector, A., Connolly, J., Harpole, W.S., Reich, P.B., Scherer-Lorenzen, M., Schmid, B., Tilman, D., van Ruijven, J., Weigelt, A., Wilsey, B.J., Zavaleta, E.S. \& Loreau, M. (2011). High plant diversity is needed to maintain ecosystem services. Nature, 477, 199-202.

Jarman, S.J. \& Kantvilas, G. (1995). Epiphytes on an old Huon pine tree (Lagarostrobos franklinii) in Tasmanian rainforest. New Zealand Journal of Botany, 33, 65-78.

Kaplan, J.O., Krumhardt, K.M. \& Zimmermann, N. (2009). The prehistoric and preindustrial deforestation of Europe. Quaternary Science Reviews, 28, 3016-3034.

Kessler, M., Keßler, P.J.A., Gradstein, S.R., Bach, K., Schmull, M. \& Pitopang, R. (2005). Tree diversity in primary forest and different land use systems in Central Sulawesi, Indonesia. Biodiversity and Conservation, 14, 547-560.

Kiebacher, T., Keller, C., Scheidegger, C \& Bergamini, A. (2016). Hidden crown jewels: the role of tree crowns for bryophyte and lichen species richness in sycamore maple wooded pastures. Biodiversity and Conservation, 25, 1605-1624.

Korpel, S. (1995). Die Urwälder der Westkarpathen. Fischer Verlag, Stuttgart.

Král, K., Vrška, T., Hort, L., Adam, D. \& Šamonil, P. (2010). Developmental phases in a temperate natural spruce-fir-beech forest: determination by a supervised classification method. European Journal of Forest Research, 129(3), 339-351. 
Krömer, T., Kessler, M. \& Gradstein, S.R. (2007). Vertical stratification of vascular epiphytes in submontane and montane forest of the Bolivian Andes: the importance of the understorey. Plant Ecology, 189, 261-278.

Kucbel, S., Saniga, M., Jaloviar, P. \& Vencurik, J. (2012). Stand structure and temporal variability in old-growth beech-dominated forests of the northwestern Carpathians: A 40years perspective. Forest Ecology and Management, 264, 125-133.

Kuuluvainen, T. (2002). Natural variability of forests as a reference for restoring and managing biological diversity in boreal Fennoscandia. Silva Fennica, 36(1), 97-125.

Kuuluvainen, T. \& Aakala, T. (2011). Natural forest dynamics in boreal Fennoscandia: a review and classification. Silva Fennica, 45(5), 823-841.

Lakatos, M. \& Fischer-Pardow, A. (2013). Nonvascular epiphytes: Functions and risks at the tree canopy. In: Lowman, M., Devy, S., \& Ganesh, T. (eds.). Treetops at Risk: Challenges of Global Canopy Ecology and Conservation, pp. 223-236. Springer New York, New York, NY.

Lawton, R.O., Nair, U.S., Pielke, R.A., Welch, R.M. (2018). Climatic Impact of Tropical Lowland Deforestation on Nearby Montane Cloud Forests. Science, 294, 584-587.

Leibundgut, H. (1993). Europäische Wälder - Wegweiser zur naturnahen Waldwirtschaft. Bern, Paul Haupt.

Lesica, P. McCune, B., Cooper, S.V. \& Hong, W.S. (1991). Differences in lichen and bryophyte communities between old-growth and managed second-growth forests in the Swan Valley, Montana. Canadian Journal of Botany, 69, 1745-1755.

Leuschner, C. \& Lendzion, J. (2009). Air humidity, soil moisture and soil chemistry as determinants of the herb layer composition in European beech forests. Journal of Vegetation Science, 20, 288-298.

Leuschner, C. \& Ellenberg, H. (2017). Ecology of Central European Forests. Vegetation Ecology of Central Europe, Vol. I. Springer Nature, Cham.

Marmor, L., Tõrra, T., Saag, L., Leppik, E. \& Randlane, T. (2013). Lichens on Picea abies and Pinus sylvestris - from the tree bottom to the top. Lichenologist, 45, 51-63.

McCune, B., Amsberry, K.A., Camacho, F.J., Clery, S., Cole, C., Emerson, C., Felder, G., French, P., Greene, D., Harris, R., Hutten, M., Larson, B., Lesko, M., Majors, S., Markwell, T., Parker, G.G., Pendergrass, K., Peterson, E.B., Peterson, E. T., Platt, J., 
Proctor, J., Rambo, T., Rosso, A., Shaw, D., Turner, R. \& Widmer, M. (1997). Vertical Profile of Epiphytes in a Pacific Northwest Old-growth Forest. Northwest Science, 71, 145-152.

Meyer, P. (1999). Bestimmung der Waldentwicklungsphasen und der Texturdiversität in Naturwäldern. Allgemeine Forst- und Jagdzeitung, 170, 203-211.

Nieder, J., Engwald, S., Klawun, M. \& Barthlott, W. (2000). Spatial distribution of vascular epiphytes (including Hemiepiphytes) in a lowland Amazonian rain forest (Surumoni crane plot) of Southern Venezuela. Biotropica, 32 385-396.

Ódor, P. \& Standovár, T. (2001). Richness of bryophyte vegetation in near-natural and managed beech stands: the effects of management-induced differences in dead wood. Ecological Bulletins, 12, 219-229.

Ódor, P., van Dort, K., Aude, E., Heilmann-Clausen, J., \& Christensen, M. (2005). Diversity and Composition of Dead Wood Inhabiting. Boletín de la Sociedad Española de Briología, 26-27, 85-102.

Ódor, P., Heilmann-Clausen, J., Christensen, M., Aude, E., van Dort, K.W., Piltaver, A., Siller, I., Veerkamp, M.T., Walleyn, R., Standovár, T., van Hees, A.F.M., Kosec, J., Matočec, N., Kraigher, H., \& Grebenc, T. (2006). Diversity of dead wood inhabiting fungi and bryophytes in semi-natural beech forests in Europe. Biological Conservation, 131, 5871.

Olson, D.M., Dinerstein, E., Abell, R., Allnutt, T., Carpenter, C., McClenachan, L., D’Amico, J., Hurley, P., Kassem, K., Strand, H., Taye, M. \& Thieme, M. (2000). The Global 200: A representation approach to conserving the earth`s distinctive ecoregions. Conservation Science Program, World Wildlife Fund, US.

Paillet, Y., Bergès, L., Hjältén, J., Ódor, P., Avon, C., Bernhardt-RöMermann, M., .. Virtanen, R. (2010). Biodiversity Differences between Managed and Unmanaged Forests: MetaAnalysis of Species Richness in Europe. Conservation Biology, 24, 101-112.

Parker, G.G. (1995). Structure and microclimate of forest canopies. Eds. Forest Canopies: A review of research on a Biological Frontier. Academic Press, San Diego.

Parviainen, J., Bucking, W., Vandekerkhove, K., Schuck, A. \& Paivinen, R. (2000). Strict forest reserves in Europe: efforts to enhance biodiversity and research on forests left for free development in Europe (EU-COST-Action E4). Forestry, 73, 107-118. 
Parviainen, J., Bozzano, M., Estreguil, C., Koskela, J., Lier, M., Vogt, P. \& Ostapowicz, K. (2007). Maintenance, conservation and appropriate enhancement of biological diversity in forest ecosystems. In: Köhl, M. \& Rametsteiner, E. (Eds.). State of Europe's forests 2007. MCPFE report on sustainable forest management in Europe. Ministerial Conference on the Protection of Forests in Europe, Liaison Unit, Warsaw.

Pearce, D.W. (2001). The Economic Value of Forest Ecosystems. Ecosystem Health, 7, 284296.

Roberts, M. \& Gilliam, F.S. (1995). Patterns and mechanisms of plant diversity in forested ecosystems: implications for forest management. Ecological Applications, 5, 969-977.

Roberts, M.R. \& Gilliam, F.S. (2014). Response of the herbaceous layer to disturbance in Eastern forests. In: Gilliam, F.S. (Ed.) The Herbaceous Layer in Forests of Eastern North America. $2^{\text {nd }}$ Edition, Oxford University Press, Oxford.

Rudel, T., Coomes, O., Moran, E., Achard, F., Angelsen, A., Xu, J. \& Lambin, E. (2005). Forest transitions: towards a global understanding of land use change. Global Environmental Change, 15, 23-31.

Schelhaas, M.-J., Nabuurs, G.-J. \& Schuck, A. (2003). Natural disturbances in the European forests in the 19th and 20th centuries. Global Change Biology, 9(11), 1620-1633.

Scheller, R. M. \& Mladenoff, D. J. (2002). Understory Species Patterns and Diversity in OldGrowth and Managed Northern Hardwood Forests. Ecological Applications, 12, 13291343.

Sillett, S.C. \& Rambo, T.R. (2000). Vertical distribution of dominant epiphytes in Douglas-Fir forests of the central Oregon cascades. Northwest Science, 74, $44-49$.

Spies, T. A., Franklin, J. F. \& Thomas, T. B. (1988). Coarse Woody Debris in Douglas-Fir Forests of Western Oregon and Washington. Ecology, 69(6), 1689-1702.

Standovár, T. (2003). A review on natural stand dynamics in beechwoods of east central Europe. Applied Ecology and Environmental Research, 1(1-2), 19-46.

Stokland, J. N. \& Larsson, K.-H. (2011). Legacies from natural forest dynamics: Different effects of forest management on wood-inhabiting fungi in pine and spruce forests. Forest Ecology and Management, 261(11), 1707-1721.

Tilman, D. (2001). Forecasting Agriculturally Driven Global Environmental Change. Science, 292, 281-284. 
Townsend, C.R., Scarsbrook, M.R. \& Dolédec, S. (1997). The intermediate disturbance hypothesis, refugia, and biodiversity in streams. Limnology and Oceanography, 42, 938949.

Trotsiuk, V., Hobi, M. L. \& Commarmot, B. (2012). Age structure and disturbance dynamics of the relic virgin beech forest Uholka (Ukrainian Carpathians). Forest Ecology and Management, 265, 181-190.

Turner, I.M., Wong, Y.K. \& Chew, P.T. (1997). Tree species richness in primary and old secondary tropical forest in Singapore. Biodiversity and Conservation, 6, 537-543.

Turner, B.L., Lambin, E.F. \& Reenberg, A. (2007). The emergence of land change science for global environmental change and sustainability. Proceedings of the National Academy of Sciences, 104, 20666-20671.

Vellak, K. \& Ingerpuu, N. (2005). Management Effects on Bryophytes in Estonian Forests. Biodiversity and Conservation, 14, 3255-3263.

Vološčuk, I. (2014). Joint Slovak.Ukraine-Germany beech ecosystems as the world natural heritage. Ekologia, 33, 286-300.

Werth, D. \& Avissar, R. (2002). The local and global effects of Amazon deforestation. Journal of Geophysical Research, 107(D20).

Wesołowski, T. (2005). Virtual conservation: how the European Union is turning a blind eye to its vanishing primeval forests. Conservation Biology, 19, 1349-1358.

Wright, S.J. (1999). Plant diversity in tropical forests. In: Pugnaire, F.I. \& Valladares, F. (Eds.). Handbook of functional ecology, New York. 


\section{Chapter 2}

Comparing the plant diversity of paired beech primeval and production forests: Management reduces cryptogam, but not vascular plant species richness
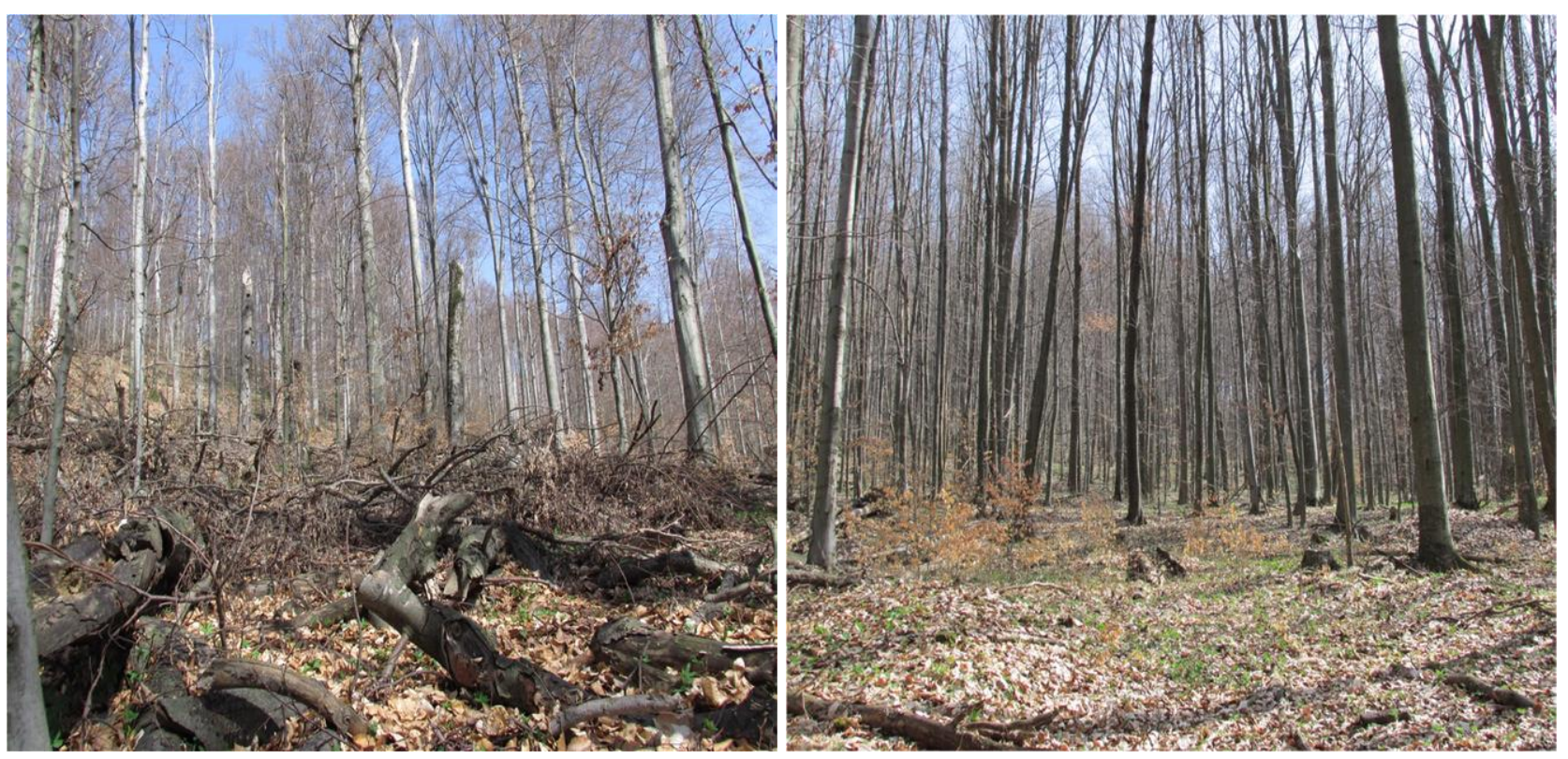

Stefan KaUfmann, Markus HaucK \& Christoph LeusCHNER Forest Ecology and Management, 2017, Vol. 400, 58-67. 


\begin{abstract}
Conflicting evidence of the impact of forest management on biodiversity exists, either decreasing or increasing species richness. Variable diversity responses may result from the adoption of different unmanaged reference systems, ranging from stands with management abandonment in the recent past to true primeval forests. We compared the species richness of epiphytic bryophytes and lichens and vascular forest floor plants in three primeval forest/production forest pairs of Fagus sylvatica in Slovakia, adopting a replicated design and a reference system without any management legacy. Mean number of bryophyte and lichen species per $500 \mathrm{~m}^{2}$-plot tended to be higher in the primeval forests, while the mean $\alpha$-diversity of vascular plants was higher in the production forests. In contrast, the B-diversity of the three plant groups as expressed by the Sørensen Dissimilarity Index was generally higher in the primeval forest plot sample, reflecting a higher heterogeneity of plant community composition and habitat diversity. Plotting cumulative species numbers against plot numbers suggests that the curves for bryophyte and lichen species richness may saturate at ca. 250 plots or $\sim 12.5$ ha in the primeval forests, but already at 30-60 plots ( $<3$ ha) in the more homogeneous production forests. Total bryophyte and lichen species numbers are estimated to be $30-100 \%$ larger in the primeval forests than the production forests. Contrary to general belief, vascular plant species richness was similarly high, or even higher, in the primeval forests when >50 plots (total area: 2.5 ha) were investigated, evidencing the importance of natural disturbance regimes for maintaining high forest biodiversity. Our results show that Fagus sylvatica primeval forests are inhabited by a species-rich epiphyte flora despite the species poverty of the tree layer. This evidence the outstanding value of primeval forest reserves for the conservation of temperate forest biodiversity.
\end{abstract}

Keywords: $\alpha$-diversity, $\beta$-diversity, bryophytes, disturbance, Fagus sylvatica, forest management, lichens, primeval forests, vascular plants 


\subsection{Introduction}

European beech (Fagus sylvatica L.) is the dominant tree species in large parts of Europe's natural temperate woodlands. Centuries of more or less intensive forest use and transformation have reduced the beech-dominated old-growth forest area to tiny fragments, while production forests, often with altered tree species composition, dominate in most areas. While windthrow, insect calamities and forest fires were once the prevailing disturbance factors, logging and other forest management activities are the dominant disturbance events in Europe's forests in our times (Kaplan et al. 2009). For forest biodiversity conservation, it is important to better understand how natural and anthropogenic disturbances modify the physical environment and thereby impact on biodiversity (Chen et al. 1999).

Since the formulation of the intermediate disturbance hypothesis (IDH) by Connell in 1978, it is generally accepted that the effect of disturbance on species diversity is not necessarily negative but depends on disturbance intensity. Moderate levels of disturbance can create habitats for additional species immigrating from outside the ecosystem, while the original species diversity remains unaffected. Thus, disturbance can rise overall species richness. Since management actions always cause disturbances, both biodiversity and ecosystem functioning differ between primeval and production forests (Bengtsson et al. 2000). Logging in primeval forests without alteration of tree species composition can be viewed as an intermediate level of anthropogenic disturbance, whereas the establishment of production forests with modified tree species composition represents a severe disturbance. Yet, even in managed forests, where the tree species composition is not altered, the intensity of logging and thus disturbance can vary considerably.

Main determinants of the species composition and diversity of the understory vegetation in temperate forest ecosystems are microclimatic factors such as light, air humidity and soil temperature, and soil moisture and soil chemistry (Friedel et al. 2006; Gilliam 2014; Ellenberg \& Leuschner 2010; Leuschner \& Lendzion 2009). Temperate broad-leaved primeval forests often consist of several canopy layers and have a small-scale patchy structure of tree groups differing in age (Korpel 1995). A consequence is a spatially more heterogeneous microclimate than found in production forests with cohort-like structure. Natural disturbances, like stand break-up after storm events, insect calamities or age-related tree mortality (Brunet et al. 2010), contribute on different scales to the high structural heterogeneity of primeval forests. Characteristic features of primeval forests, which usually are lacking in production forests, are the presence of tall over-mature trees and large amounts of deadwood in different stages of 
decay (Bunnell \& Houde 2010; Jonsson et al. 2005; Ódor \& van Hees 2004). Deadwood represents an indispensable habitat for many bryophytes and lichen species, but in late stages of decay also represents a substrate for the establishment of vascular plants, including tree offspring, which profit from reduced competition (Bače et al. 2012; Dittrich et al. 2013). The deadwood legacy from the previous tree generation also bridges the lack of microsites for many epiphytic bryophytes and lichens in regrowing primeval forests, while absence of deadwood hampers the colonization of production forests after intense timber harvest (Dittrich et al. 2013). Many authors have studied the effect of forestry on the species richness of wood-inhabiting cryptogams (Király et al. 2013; Lonsdale et al. 2008; Nascimbene et al. 2013) and vascular plants (Bremer \& Farley 2010; Decocq et al. 2004; Wagner et al. 2011) in the temperate forests of Europe and other regions. Various studies suggest that bryophytes and lichens respond more sensitively to forest management-related changes in forest structure than vascular plants, but these studies typically addressed only one systematic group, either the vascular forest floor vegetation (e.g. Aude \& Poulsen 2000) or cryptogamic epiphytes (Bardat \& Aubert 2007; Nascimbene et al. 2007). Systematic comparisons between temperate primeval and production forests with respect to vascular plant, bryophyte, and lichen diversity have been conducted in the temperate and boreal regions of North America (Lesica et al. 1991; Halpern \& Spies 2008) but are lacking for Europe.

We investigated the vascular plant, bryophyte and lichen flora in three Fagus sylvatica primeval/production forest pairs in eastern Central Europe and tested the hypotheses that (1) the $\alpha$-diversity of vascular plants is higher in production forests in agreement with the intermediate disturbance hypothesis, while bryophyte and lichen $\alpha$-diversity do not meet the predictions of IDH, and (2) the B-diversity of all three systematic groups is higher in primeval forests reflecting the high spatial heterogeneity of these forests. If correct, this would suggest to focus on $\beta$-diversity and the regional species pool rather than on $\alpha$-diversity in assessments of the conservation value of natural and managed forests.

\subsection{Material and methods}

\section{Study areas}

The study was conducted in the western Carpathian Mountains in eastern Slovakia where some remnant beech primeval forests have survived (Fig. 2.1). This region belongs to the eastern part of the distribution range of $F$. sylvatica. These forests were added in 2007 to the World Heritage List of UNESCO (Primeval Beech Forests in the Carpathians), including several forests in 
Slovakia and Ukraine. Three primeval forest areas were selected for study, Havešová, Stužica (in Poloniny National Park) and Kyjov (in the Vihorlat Protected Landscape Area; detailed information on these conservation areas is found in Vološčuk (2014)). The beech primeval forest area extends over 659 ha in Stužica, 171 ha in Havešová, and 53 ha in Kyjov. These stands have not been subjected to any forest management activity for several hundred years.

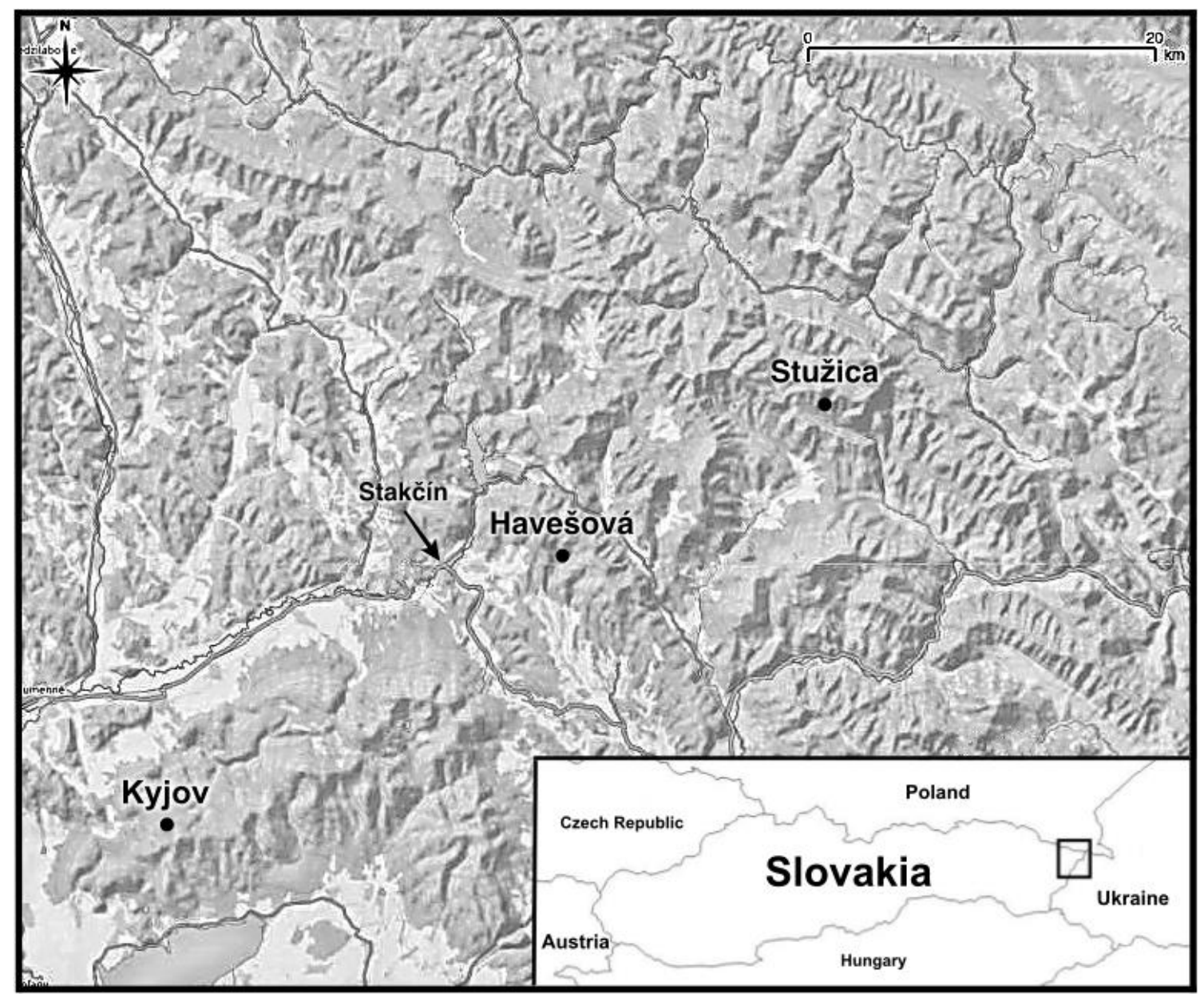

Figure 2.1. Location of the three study areas in eastern Slovakia.

In close vicinity to the primeval stands, three beech production forests were selected in Havešová (3.8 ha), Kyjov ( 8.3 ha) and Stužica (6.9 ha). The age of these stands varied between 90-100 (Havešová and Kyjov) and 70-100 years (Stužica). These beech forests are managed in a shelterwood cutting system with two cuts conducted within 10 years at the end of the production cycle, while no or only scarce management activities are conducted in the first 8090 years. This type of forest management is the most widespread in Slovakian beech production forests and practiced in strips parallel to the slope, structuring the production forests in longitudinal sections of beech cohorts of similar age and high stem density (Green Report 2009; Marušák 2007). The rotation period is often relatively short (typically 80-100 years) with the 
consequence that more than $90 \%$ of the Slovakian beech production forests are younger than 100 years (National Forest Centre 2009).

All studied forests are located at sub-montane to montane elevation. The three sites differ slightly in elevation; these differences are related to some differences in mean annual precipitation and temperature. Due to different geologies (andesite vs. flysh), the soils in Kyjov (dystric Cambisols) are nutrient-poorer than those in Havešová and Stužica (eutric Cambisols, Table 2.1) (Vološčuk 2014). While south-facing slopes dominate in Havešová and Stužica, the forests in Kyjov grow predominantly on north-facing slopes.

Table 2.1. Some physiographic characteristics of the three primeval forest sites in eastern Slovakia after Korpel (1995). The conditions in the nearby production forests are very similar.

\begin{tabular}{lccc}
\hline Sites & Havešová & Kyjov & Stužica \\
\hline Elevation m a.s.l. & $550-650$ & $700-820$ & $700-950$ \\
$\begin{array}{l}\text { Mean annual precipitation } \\
\text { mm yr }^{-1}\end{array}$ & $800-850$ & $950-1000$ & $900-1200$ \\
Mean annual temperature ${ }^{\circ} \mathrm{C}$ & $6-6.5$ & $5.2-5.7$ & $4-5$ \\
Geology & Carpathian Flysh & Andesite & Carpathian Flysh \\
Soil type & Eutric Cambisol & Dystric Cambisol & Eutric Cambisol \\
Aspect & S-SW & N-NE & S \\
\hline
\end{tabular}

Based on our relevés of the vascular forest floor vegetation, it is not possible to assign the local communities to any of the acidophilous beech forest associations (alliances Luzulo-Fagion sylvaticae and Fagion sylvaticae) listed for Slovakia by Slezák et al. (2016). Most relevés can best be assigned to the Dentario-glandulosae Fagetum, a western Carpathian association (Neuhäusl et al. 1982) characterized by Dentaria glandulosa, a Carpathian endemic and other eastern European species, like Symphytum cordatum. Fagus sylvatica dominates the tree layer in all study areas. In the primeval forests of Havešová and Kyjov, a few individuals of other tree species like Acer platanoides and Fraxinus excelsior were admixed. In Stužica, beech was locally associated with major proportions of Abies alba, which was sporadically even dominant in the shrub layer. The production forests had higher shares of tree species other than beech as compared to the primeval forests, though beech was always dominant.

\section{Study design}

Forty circular plots of $500 \mathrm{~m}^{2}$ size were established in each primeval forest in systematic grids that had a mesh size of $140 \mathrm{~m}$ (Havešová), $100 \mathrm{~m}$ (Stužica) or $64 \mathrm{~m}$ (Kyjov) as minimum distance between neighboring plot centres. In Stužica, we selected all plots at elevations $<1.000$ 
$\mathrm{m}$ due to a tree species change toward higher elevations. For that reason, the study area of 659 ha was reduced resulting in shorter distances between the plot centres. In Kyjov, the smallest study site, $64 \mathrm{~m}$ was the maximum distance between the plot centres to guarantee the establishment of 40 plots. A 100 m-wide buffer zone was excluded from the margins of each primeval forest to avoid influences from the adjacent production stands.

Due to the typical management regime applied to beech production forests in eastern Slovakia that starts with the clear-cut of forest strips and is followed by the subsequent regrowth of tree cohorts, the size of the selected production forests was smaller than that of the nearby primeval forests. Ten plots of $500 \mathrm{~m}^{2}$ size were selected in each production stand in the same way as described above. Due to the relatively small size of the production forests, $50 \mathrm{~m}$ was the maximum possible distance between the plot centres in these stands to avoid interference among the 10 plots and with the surroundings.

In addition, 12 of the 40 plots in each primeval forest and four of the 10 plots in each production forest were selected, in which microclimate and canopy architecture (LAI2000 Plant Canopy Analyzer, LiCor, Lincoln, NE, USA) were analyzed, either using stratified random sampling (primeval forests) or random sampling (production forests).

The primeval forests of Havešová, Kyjov, and Stužica are subsequently labelled with $\mathrm{H}, \mathrm{K}$, and $\mathrm{S}$, respectively, the corresponding production forests with HP, KP, and SP.

\section{Stand properties and microclimate}

Within the sample plots, the diameter at breast height (DBH) of all trees $\geq 7 \mathrm{~cm}$ was measured at $1.3 \mathrm{~m}$ height. However, for the counts of living trees and deadwood (lying and standing), only trees with a diameter $\geq 15 \mathrm{~cm}$ were taken into account. The analyzed stand properties are summarized in Table A2.1. In general, the mean number of living trees per plot was in all three study regions higher in the production forests, whereas the living trees had a higher mean dbh in the primeval forests. The three primeval forests had mean stores of dead coarse wood mass of $53 \mathrm{Mg} \mathrm{ha}^{-1}$, which is roughly 17 times more than in the production forests $\left(3 \mathrm{Mg} \mathrm{ha}^{-1}\right)$. The mean number of dead standing trees and the corresponding dbh values were higher in the primeval forests, even though the difference between primeval and production forests was not significant in all study areas. The mean number of dead lying trees was significantly higher in the primeval forests in the Havešová and Stužica regions, but was not significantly different, when all six forests are compared. The mean dbh of lying deadwood was generally higher in the primeval forests, but the difference to the production forests was significant only in 
Havešová.

Canopy light transmissivity was characterized by estimating the leaf area index (LAI) with a LAI2000 Plant Canopy Analyzer Licor (Lincoln, Nebraska, USA) at 21 locations in the plots. Relative air humidity and air temperature were hourly recorded from March 2014 to November 2015 with HOBO pro v2 data loggers (Onset, Cape Cod, Massachusetts, USA) on half of the plots selected for microclimate measurement. The sensors were mounted at $1.5 \mathrm{~m}$ height on the north-facing side of the tree growing closest to the plot center. The results are summarized in Table A2.1. We found no principal difference in LAI and relative air humidity between the primeval and production forests. Mean air temperature varied between the regions, but not between the two forest types in a study area.

\section{Vegetation analysis}

Vegetation sampling was done mainly in the growing season 2014 and supplemented by records from fall 2013 and spring 2015. With respect to the ground vegetation, the cover of all vascular plants, bryophytes and lichens was estimated in the $500 \mathrm{~m}^{2}$ plots. For woody plants, the cover was estimated separately in the herb layer $(<0.5 \mathrm{~m}$ height), shrub layer $(<2 \mathrm{~m})$ and tree layer $(>2 \mathrm{~m})$. Terricolous bryophytes and lichens were noted in a separate cryptogam layer. The cover of all species was estimated using 5\%-classes for species covering $\geq 10 \%$ of the total plot area. For species covering less than $10 \%, 1 \%$-classes were used; $0.1 \%$ (one individual) and $0.5 \%$ (more than one individual) categories were assigned to species occurring on $<1 \%$ of the plot area (Dittrich et al. 2013). Epiphyte species were recorded from the trunk in 0-2 $\mathrm{m}$ height of all trees within the $500 \mathrm{~m}^{2}$ plots. The cover of bryophytes and lichens on living and dead standing trees was estimated using the same percent classes as applied for the ground vegetation. Presence/absence data were recorded for bryophytes and lichens from the whole upper surface and the flanks of downed deadwood.

Herbarium specimens were collected if species could not be identified in the field. For the identification of the bryophytes and lichens, light microscopy was used. Further, thin layerchromatography (TLC) was performed according to Orange et al. (2001), where the qualitative analysis of secondary lichen metabolites was appropriate for species identification. The TLC results were evaluated by using the LIAS Metabolites data base (Elix et al. 2012). All collected specimens were deposited in the private herbarium of the first author. Nomenclature follows Danihelka et al. (2012) for vascular plants, Hodgetts (2015) for bryophytes and Guttová et al. (2013) for lichens. 


\section{Data analysis}

Arithmetic means \pm standard errors are presented throughout the paper. Data were tested for normal distribution with the Shapiro-Wilk test and for the homogeneity of variances with Levene's test. Pairwise comparison between data sets was done with Student's t-test (normally distributed data) and the Mann-Whitney U test (not normally distributed data). If both tests were positive, an analysis of variance (ANOVA) was calculated for multiple comparisons. Otherwise, Welch's F-test (normal distribution, heterogeneous variances) or the Kruskal-Wallis test (not normally distributed data) was applied to test for overall differences in the data set. Multiple pairwise comparison between means was done with Tukey's post hoc test for normally distributed data or other- wise a Bonferroni-corrected Mann-Whitney U test was applied.

We used the R-package "spdep" (version 0.6-13) and computed Moran's I test for spatial autocorrelation of the sampling units within each primeval and production forest. Sample-based rarefaction/extrapolation with $95 \%$ confidence intervals was computed with $\mathrm{R}$ software (RStudio Team 2015) using the R package "iNEXT” (Hsieh et al. 2015) to compare the species richness between the production and primeval forests. Additionally, sample-completeness curves were constructed to illustrate, how well the whole species pool of the studied forests was detected. The species' frequency of presence was used for the estimations. This method allows to compare the species richness ( $\alpha$-diversity) of different realized or hypothetical sample sizes with reliable statistical inference (Chao et al. 2014). As the starting point, we used the observed species richness of the total number of sampling units in each primeval and production forest. Further plots were then randomly selected and species richness was estimated via rarefaction and extrapolation. In this step, we used Hill numbers, a mathematically unified family of diversity indices differing among themselves only by an exponent q. In order to characterize the species richness of primeval and production forests, we used the first Hill number $(q=0)$. Analyses with Hill numbers of the order $\mathrm{q}=1$ (Shannon diversity) and $\mathrm{q}=2$ (Simpson diversity) were not conducted. However, extrapolation with the Hill number $q=0$ is reliable only up to a doubling of the recorded reference sample size (Colwell et al. 2012). Beyond that, the predictor for $\mathrm{q}=0$ (i.e. Chao 2 species richness estimator for presence data) may be biased (Chao et al. 2014). If the $95 \%$ confidence intervals do not overlap, species numbers differ significantly at $P \leq 0.05$ (Colwell et al. 2012). Species turnover (ß-diversity) was calculated as Sørensen dissimilarity using the R package "betapart” (Baselga et al. 2015). Distances between the plot centres differed between the primeval and production forests due to variable forest areas. Thus, we calculated the Sorensen dissimilarity index (SDI) for plot-pairs of production and primeval forests, which had similar distances between plots. To do so, we randomly selected each five 
plot-pairs in every production forest with plot distances equal to those in the corresponding primeval forest; plots in the production forest with smaller distance were omitted. Non-metric multidimensional scaling (NMDS) (Clarke 1993) was performed to examine differences between the forest types in terms of species composition using PC-Ord 5.14 (McCune \& Mefford 2006).

\subsection{Results}

\section{Plot-level species richness}

The mean number of bryophyte species per $500 \mathrm{~m}^{2}$-plot tended to be higher in the primeval forests than in the production forests, but this difference was significant only in Stužica (Table 2.2). Plot-level lichen diversity tended to be higher in the primeval forests in two regions ( $K$ and S) but showed the opposite trend in Havešová. In contrast to the cryptogams, vascular plant species richness in a plot was about twice as high in the production forest as compared to the primeval forest in Havešová (difference significant) and in Stužica (not significant), while no difference between primeval and production forest was visible in Kyjov (Table 2.2).

Plotting cumulative species number against plot number produced sample-based rarefaction/extrapolation curves for epiphytic bryophytes and lichens, and vascular plants. The results are depicted separately for the six forests (Fig. A2.1) and as average over the each three primeval and production forests (Fig. 2.2). In addition, rarefaction and extrapolation curves for species occurring on lying deadwood (bryophytes and lichens pooled) were also computed (Fig. A2.5) to examine the influence of the largely different deadwood amounts in production and primeval forests on plant diversity.

For epiphytic bryophytes and lichens, the primeval forest curves are much steeper than those of the production forests with no overlap of confidence intervals (Fig. 2.2a and b), evidencing significantly smaller species numbers per area in the production forests. In contrast, there was no significant difference in species richness detectable between both forest types for vascular plants (Fig. 2.2c). While the species richness in the $500 \mathrm{~m}^{2}$-plots was slightly higher in the production forests, the species number/plot number curve was much steeper in the primeval forests, suggesting that cumulative species number is not higher or even lower in production forests when more plots are investigated. 
造

吾

$\exists$.

总总

పี

$\Xi \overparen{2}$

刍

齐

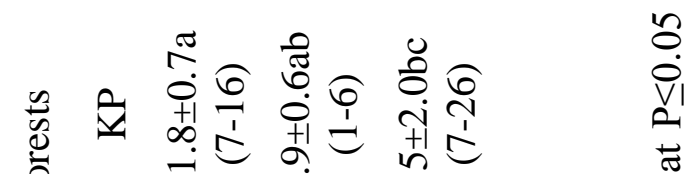

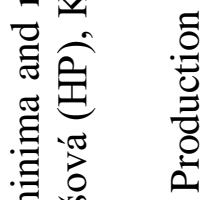

过要

贸

$+I . \Xi$

음 站

$\stackrel{\sim}{\natural}$

유. 옹

흥

竞

है

㤩

$\stackrel{0}{0}$

क्ष

壳空

흘

근

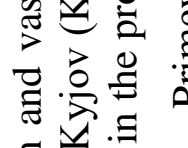

월

ब范

东家

政

임

寻

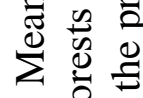

نั

을

¿ $=$ ल

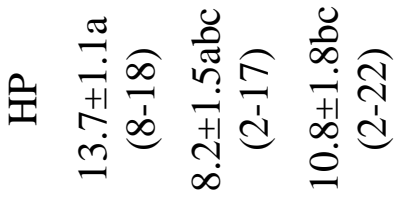

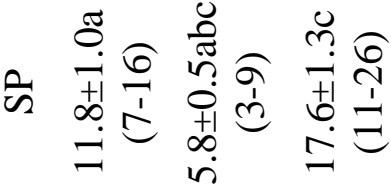

ธั

岕

을

苍

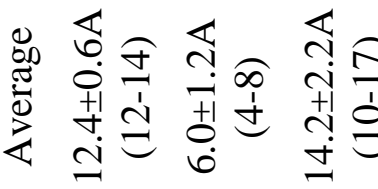

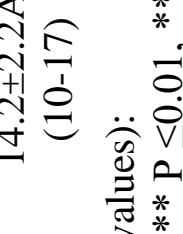

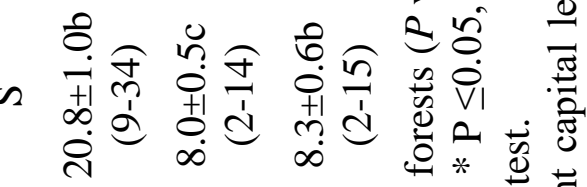

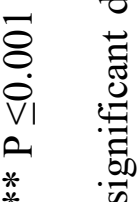

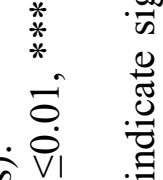

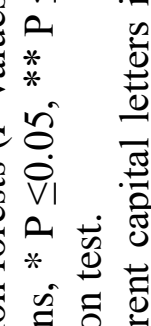

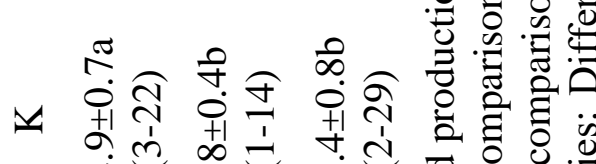

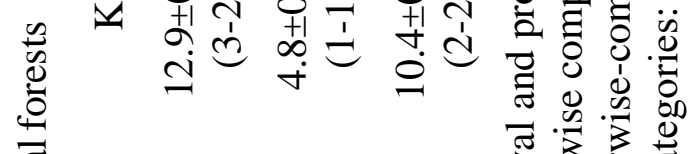

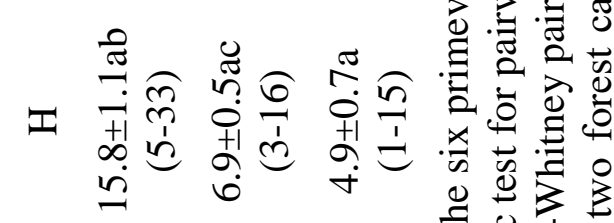
ฮั

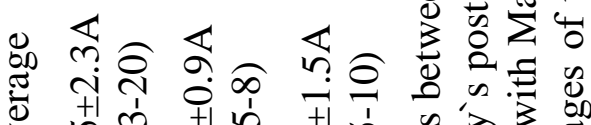

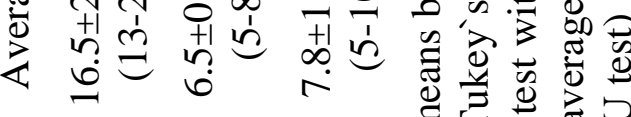

$\Leftrightarrow$ ํํำ 


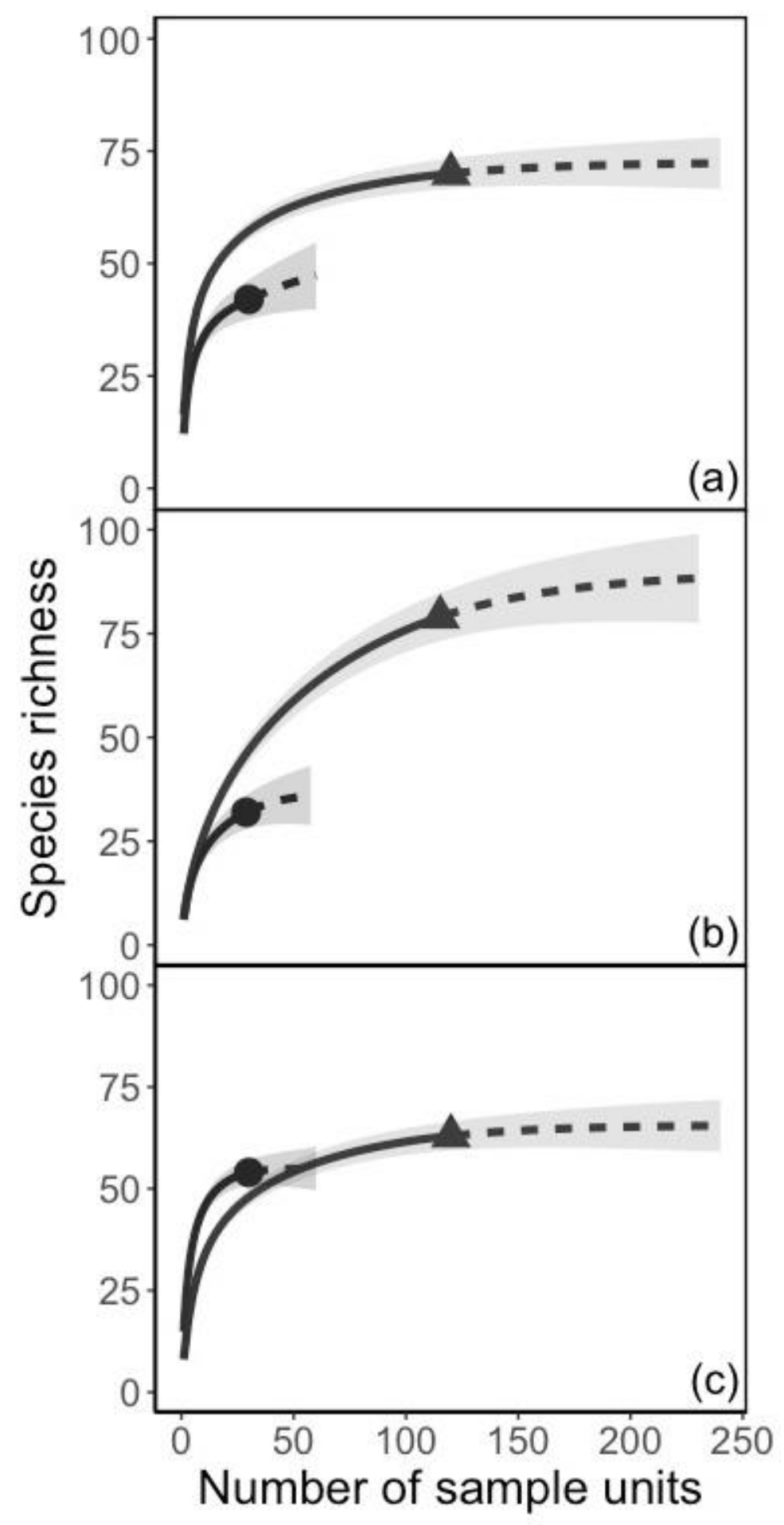

Figure 2.2. Rarefaction/extrapolation curves for epiphytic bryophytes (a), lichens (b) and vascular plants (c) in the primeval and production forests. The species numbers of the three study areas (Havešová, Kyjov and Stužica) were added (y-axes have different scaling). Confidence intervals are shaded. Note the different number of plots in the production $(\mathrm{N}=30)$ and primeval forests $(\mathrm{N}=120)$. 'Dashed' line = extrapolation; 'solid' line = interpolation. 'Triangle' and 'circle' denote primeval and production forest, respectively. 
For the bryophytes and lichens of the primeval forests, our data suggest saturation of species numbers to occur only at plot numbers $>250$. From the shape of the rarefaction/extrapolation curve for vascular plants, it appears that saturation may already occur at about 150 plots in the primeval forests. In the production forests, in contrast, vascular plant species richness already shows saturation at about 30 sampling units, while a slight increase of the bryophyte diversity curve is still detectable. Lichen species richness in the production forests may also saturate at ca. 60 plots, which is much less than in the primeval forests.

A separate analysis for the six forests yielded corresponding results for bryophytes and lichens (Fig. A2.1). The rarefaction/extrapolation curves increased up to 80 plots and beyond for bryophytes and lichens in all three primeval forests, while the curves reached near-saturation already at 20 or 30 plots in the production forests. However, the difference between primeval and production forests was significant only in Havešová and Stužica. In Kyjov, the number of bryophytes was higher in the primeval forest, but the confidence intervals were overlapping. The patterns were similar for lichen diversity, but the confidence intervals overlapped in Havešová and Kyjov, and a significant difference between primeval and production forest was visible only in Stužica (Fig. A2.1). As for bryophytes, the extrapolated species number/plot number curves increased in the primeval forests to 80 plots, but saturated at about 20 plots in the production forests.

The patterns of vascular plant diversity differed from those of the cryptogams, in that the production forests reached higher species numbers for 20 plots than the primeval forests, at least in Havešová and Stužica. However, this relation tended to reverse for 40 plots and beyond, and the extrapolated species number/plot number curves of the primeval forests increased further and crossed the production forest curves. Only in Havešová, our data indicate a higher vascular plant species richness of the production forests also for high plot numbers, because the species/plot curve did not saturate at 20 plots. Additional rarefaction/extrapolation curves were calculated with equal sample size per forest type (10 plots, extrapolated to 20) to account for the unbalanced number of sampling units in production and primeval forests (see Fig. A2.2: pooled over the three forests, and A2.3: per forest stand, both in the Appendix). The results were not principally different from the results obtained with the unbalanced data set (see Fig. 2.2).

For examining how well the whole species pool in a forest was detected by sampling an increasing number of plots, we calculated sample-completeness curves for the six primeval and production forests for bryophytes, lichens and vascular plants (Fig. A2.4), and also calculated 
curves for the pooled plot sample of the three forests (Fig. A2.2). In general, the species pool of lichens and vascular plants in a stand was better detected in the production forests than in the more heterogeneous primeval forests (the majority of differences was significant between production and primeval forests).

\section{Species turnover between plots}

The $\beta$-diversity of bryophytes, lichens and vascular plants in the primeval forest plots tended in general to be higher than in the production forest plots (Fig. 2.3), indicating a higher heterogeneity of plant community composition in the primeval forests. However, the difference between the two forest types was significant only for bryophytes (mean over the three sites), for lichens only in Stužica, and for vascular plants in Kyjov and Stužica. In contrast, the opposite tendency for a higher species turnover in the production forest appeared only in one case (lichens in Kyjov, difference not significant). Small-scale habitat variation seemed to be particularly high in Kyjov, where highest Sørensen Dissimilarity Indices were observed for lichens and vascular plants. Comparing the three production forests shows that the betweenplot dissimilarity of the bryophyte communities across the plots was comparable in Havešová, Kyjov and Stužica, while the three forests differed with respect to lichen and vascular plant ßdiversity (Fig. 2.3b and c).

\section{NMDS ordination of the primeval and production forest communities}

According to NMDS ordination, the lichen communities showed on axis 1 the clearest distinction between primeval and production forests of all three systematic groups, followed by the bryophyte communities. The two cryptogam groups further revealed in both the primeval and production forests a relatively clear separation of the communities of the Havešová, Kyjov and Stužica regions along axis 2. In contrast, the vascular plant communities showed broad overlap between the primeval and production forest communities in the ordination diagram, and the three regions were less clearly separated (Fig. 2.4).

\subsection{Discussion}

\section{Plant species richness of primeval forests}

In the 120 Slovakian primeval forest plots of $500 \mathrm{~m}^{2}$ size, we recorded 82 bryophytes, 82 lichen (plus three non-lichenized fungi) and 50 vascular plant species in total. In other words, on 6 ha of beech primeval forest, about $10 \%$ of the bryophyte flora and $6 \%$ of the lichen flora, but only 
$2 \%$ of the vascular flora of Slovakia were found. Given these facts, it was a surprise that the species numbers of epiphytic lichens in the $500 \mathrm{~m}^{2}$-plots were on average not higher, and those of epiphytic bryophytes only slightly higher in the primeval forests as compared to the nearby production forests. Diversity differences in the epiphyte flora only manifested at larger spatial scales. In fact, when 10 plots were investigated, cumulative bryophyte and lichen species numbers were $\sim 30 \%$ larger in the primeval forests and this difference increased with increasing plot number. The rarefaction/extrapolation curves based on pooled data from the three regions indicate that the total bryophyte species number is at least $30 \%$ larger and the lichen species number ca. $100 \%$ larger in the primeval forests, when 120 plots are examined. This matches results of other comparisons between true old-growth and managed forests. For example, Lesica et al. (1991) counted a higher number of epiphytes in old-growth forests than in nearby production forests in Montana (USA). In old-growth beech forests on acid soil in northern Germany with management only in the distant past, total bryophyte numbers were $20 \%$ and lichen species numbers $37 \%$ greater than in nearby beech production forests (von Oheimb et al. 2004).

Numerous comparisons of epiphyte diversity have been conducted between managed and unmanaged forests, in which the human impact had ceased only decades ago and a legacy of past management is still detectable in the forest structure. These studies provided mixed results and were less conclusive than comparisons with true primeval forests. While the majority of these studies showed higher epiphyte diversity in the unmanaged forests as well (e.g. Aude \& Poulsen 2000; Hofmeister et al. 2015; Vellak \& Ingerpuu 2005), others found equal or even higher diversity in the managed stands (Boch et al. 2013a; Müller et al. 2015). A meta-analysis covering 120 European studies on the diversity of managed and unmanaged forests revealed a significantly lower lichen and bryophyte species richness in managed as compared to unmanaged forests which were at least 20 years without human impact (difference significant for lichens, marginally significant for bryophytes; Paillet et al. 2010). This analysis has been criticized with the argument of potentially biased data, as protected forests might have been selected in more diverse regions than managed forests, questioning the validity of diversity comparisons (Halme et al. 2010; Schulze et al. 2016). Since we investigated primeval and production forests in direct vicinity to each other, this criticism is not relevant for our study. Studies reporting higher epiphyte diversity in managed than unmanaged forests (e.g. Müller et al. 2015) must be interpreted with care, because the unmanaged reference sites typically are far from the state of an old-growth or primeval forest, as they contain only low deadwood amounts and a management imprint on forest structure is still clearly present. 


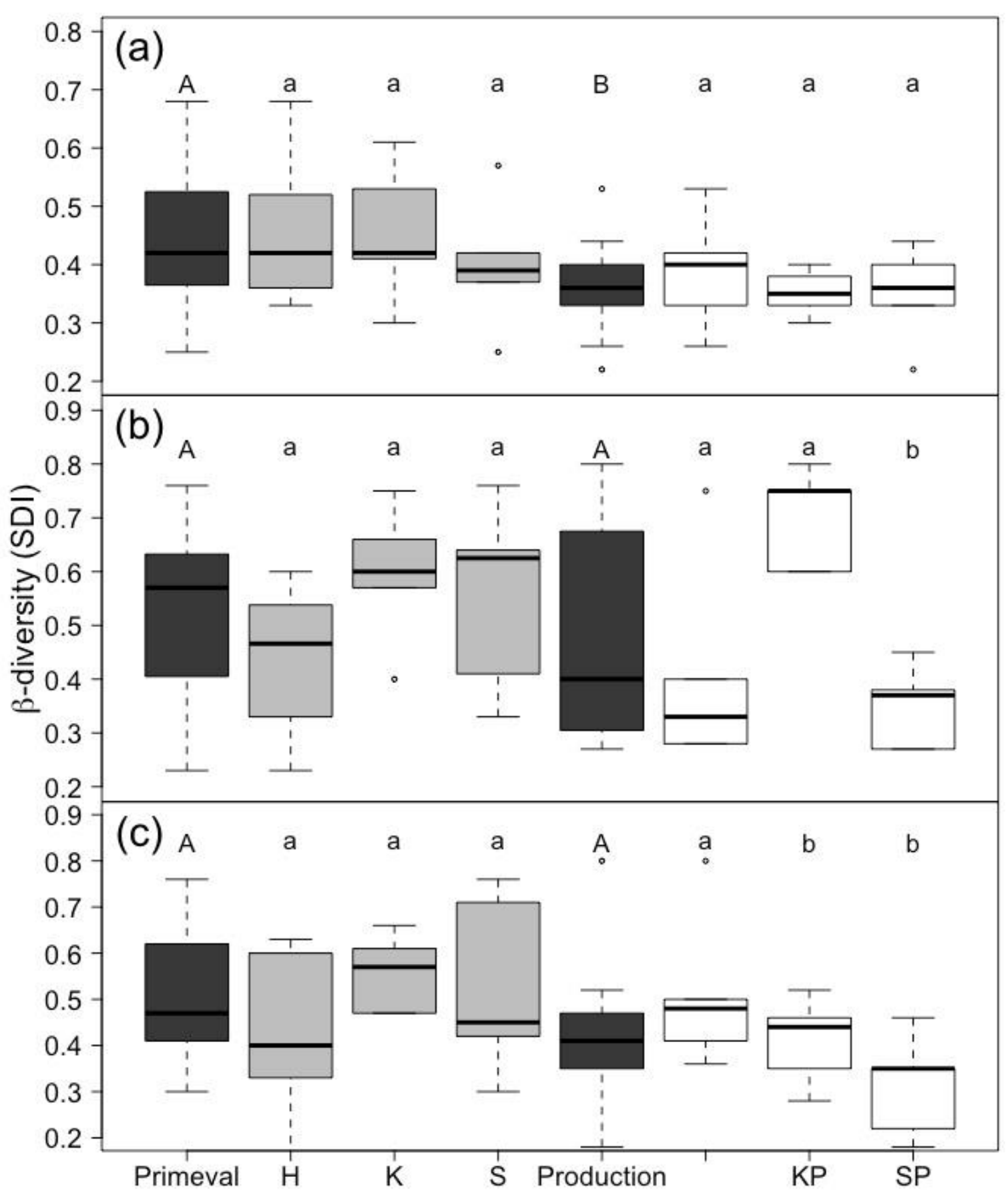

Figure 2.3. $\beta$-diversity (Sørensen Dissimilarity Index) of the epiphytic bryophyte (first row), lichen (second row) and vascular plant communities (third row) of each five plot-pairs of the three primeval forests Havešová $(\mathrm{H}), \operatorname{Kyjov}(\mathrm{K})$ and Stužica $(\mathrm{S})$ and the three corresponding production stands (single letters $=$ primeval forests; added ' $\mathrm{P}$ ' = production forests). The distances in the plot pairs were the same for production and primeval forests. Also given is the mean $\beta$-diversity of all primeval and production forest plots pooled (box-whisker-plots with median, 25- and 75-percentiles and extremes). Note different scaling of y-axes. Different small letters indicate significant differences in mean $\beta$-diversity between each primeval and production forest (ANOVA: $\mathrm{P} \leq 0.05$, Kruskal-Wallis test; $\mathrm{P} \leq 0.05$ ). Different capital letters indicate significant differences in mean $\beta$-diversity between primeval and production forests.

In contrast to epiphytic cryptogams, forest management-related disturbance and alteration of 
stand structure did not lead to a decrease in vascular plant species richness in the production forests as compared to the primeval forests in Slovakia. This suggests that vascular forest floor plants are less sensitive to management-related alterations of forest structure than epiphytic bryophytes and lichens. While plot-level species richness was on average higher in the production forests for this plant group, the species number/plot number curves point at similar vascular plant species pools, when larger primeval and managed forest areas are considered. Various studies have compared the species richness and composition of the forest floor vegetation in primeval or old-growth forests and production forests. They have produced mixed results, depending on the type and intensity of forest management, the type of forest, and forest age or continuity. For example, Halpern and Spies (2008) found a higher plant species richness in old-growth as compared to managed forests in the Pacific Northwest, while Scheller and Mladenoff (2002) reported a higher diversity in production forests. Other studies comparing managed and unmanaged forests with a legacy of past use often reported a higher plant species richness in production forests (Boch et al. 2013b; Brunet et al. 1996) due to the immigration of non-forest plant species and taxa indicating disturbance (e.g. Boch et al. 2013b; Degen et al. 2010; Tinya et al. 2009). We also observed the presence of disturbance indicators in the production forests, but many of these vascular plant species were also present in the primeval forests on a few plots with natural disturbance, where uprooting of trees resulted in bare topsoil. As a consequence, production forest species richness did not exceed that of the primeval forests in Slovakia. We assume that many vascular plant species, which today mainly occur in open landscapes and colonize managed forests after disturbance, have natural occurrences in primeval forest landscapes at places with natural disturbance such as windthrow, insect calamities and forest fires. This creates a heterogeneity of habitats in natural woodlands, which is rare in production forests with cohort-like age structure.

Our study provides strong support for the assumption that primeval forests play an outstanding role for the conservation of the characteristic cryptogamic and phanerogamic flora of woodlands. Despite their very low tree species diversity, Fagus sylvatica primeval forests harbor a remarkably species-rich bryophyte and lichen flora, and the vascular plant flora is as species-rich as in production forests when a sufficiently large area is considered. Comprehensive inventories of the invertebrate fauna and the fungal communities in old-growth beech forests in Europe support this conclusion (e.g. Dorow et al. 2007; Dörfelt 2007). The difference in cryptogam richness between managed and primeval forests may even be larger in Central and Western European beech forests than recorded for Slovakia here, as management intensity is generally higher in the former. Our replicated study with paired primeval and man- 
aged forest sites avoids possible methodological shortcomings of other comparative studies and meta-analyses, which have addressed the question of forest management impact on species richness. Our analysis is among the very few studies, which studied true primeval forests with very long absence of human impact as a reference. Comparative analyses between managed and unmanaged forests, which have been influenced by logging activities in the nearer past, are probably not suited to answer this question. Our study further demonstrates that IDH is applicable to the flora of temperate forests only, when the disturbance response of the various systematic groups is measured with different group- specific disturbance intensity scales.

\section{Large structural heterogeneity as the main cause of the high species diversity in} primeval forests

The spatial heterogeneity of forest structure, measured either as variation in the availability of special habitats or of resource supply such as light, is hypothesized to exert a major control on the species diversity of woodlands (Halpern \& Spies 2008). As evidenced by several empirical studies (Crow et al. 2002; Larrieu et al. 2012; Ódor \& Standovár 2001), primeval forests with natural disturbance regimes offer a much higher variability of substrates and microclimatic conditions suitable for epiphytes and saproxylic organisms than most spatially more uniform production forests (Crist \& Veech 2006). In our study, this is reflected in the generally higher B-diversity found in the primeval forests as compared to the production forests, evidencing higher species turnover between plots and the presence of more types of epiphytic and forest floor communities per area in the former. This habitat heterogeneity is graphically illustrated by the wider dispersion of primeval forest plots along the first two axes of the NMDS ordination. In support of hypothesis (2), community dissimilarity across neighboring plots (Bdiversity) was the main determinant of species richness in the primeval forests and not plotlevel species rich- ness ( $\alpha$-diversity).

Cryptogams and phanerogams differ in their dependence on habitat quality and habitat heterogeneity. Whereas the occurrence of forest floor vascular plants is to a large part controlled primarily by the availability of light, water and nutrients (Barbier et al. 2008; Degen et al. 2010; Ellenberg \& Leuschner 2010; Kelemen et al. 2012), epiphytic bryophytes and lichens are mainly dependent on the availability of suitable substrates, i.e. tall trees with large dbh, and a high amount of deadwood (Dymytrova et al. 2014; Fritz et al. 2008, 2009; Hauck 2011; Odor et al. 2005, 2014). Our study clearly indicates that the structural diversity in terms of suitable substrates for epiphytes is much higher in the primeval forests (Table A2.1), and many microhabitat types are mostly lacking in production forests (Larrieu et al. 2012; Ódor \& 
Standovár 2001). For this reason, production stands lack much of the structural complexity characteristic of old-growth forests (Crow et al. 2002).

Apart from habitat heterogeneity, stand continuity has been identified as another important determinant of the species richness of epiphytic cryptogams and it is also important for many forest floor vascular plants (Fritz et al. 2008). Transplant experiments conducted by Hilmo and Såstad (2001) and Hilmo (2002) showed that the environmental conditions in production forests are not necessarily unfavorable for the growth of lichen species characteristic for old-growth forests. However, limited dispersal ability and poor diaspore production of some lichen species in combination with long distances between propagule sources and potential sites for colonization are a main cause of the absence of rare bryophyte and lichen species in production forests (Hilmo \& Såstad 2001; Hilmo 2002; Hedderson 1992). As a consequence, preserving propagule sources in production forests appears to be a highly effective means of promoting the persistence of at least some epiphyte taxa with close association to primeval forest attributes (Sillett et al. 2000).
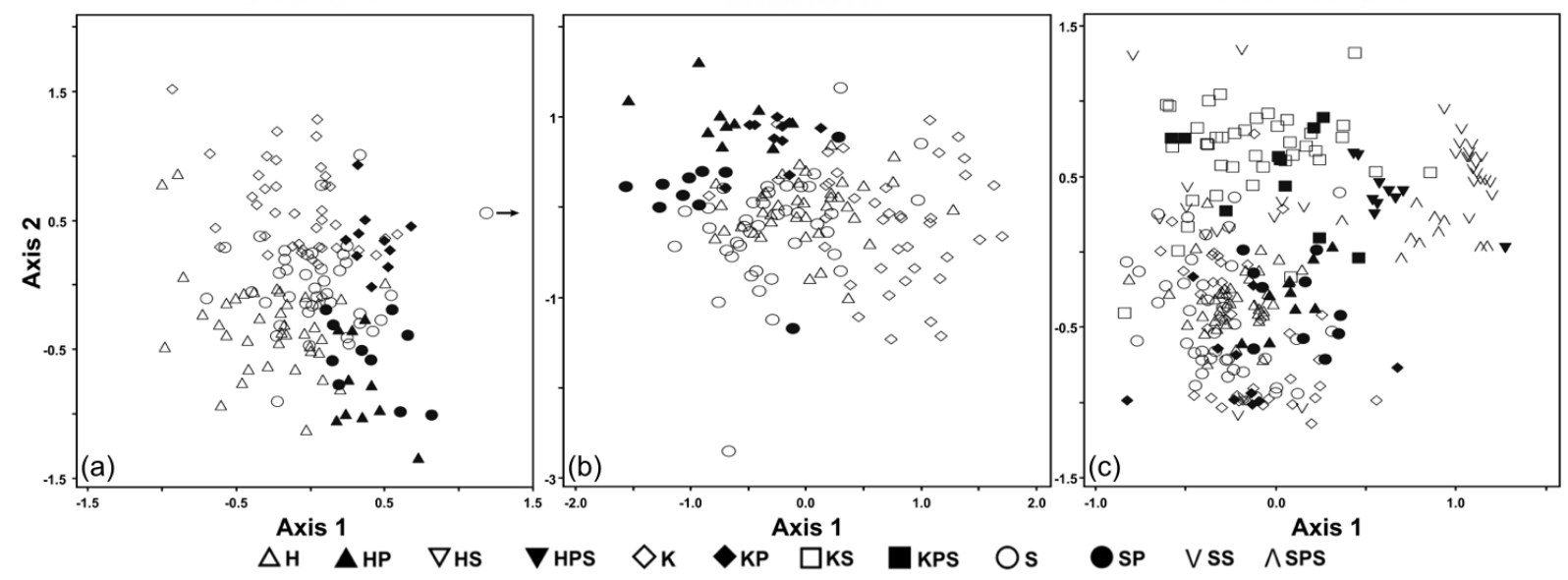

Figure 2.4. NMDS of the epiphytic bryophyte, lichen and vascular plant communities in the study areas, Havešová $(\mathrm{H})$, Kyjov $(\mathrm{K})$ and Stužica $(\mathrm{S})$ (single letters= primeval Forest; added ' $\mathrm{P}$ '= production Forest, added ' $\mathrm{S}$ '= vegetation survey in spring). (a) Bryophytes. Mean stress in real data: Axis 1 46.614, Axis 2 26.760. (b) Lichens. Mean stress in real data: Axis 147.608 , Axis 2 28.979. (c) Vascular plants. Mean stress in real data: Axis 1 48.099, Axis 24.197.

\section{The role of natural disturbances for forest plant diversity}

Our study clearly demonstrates that disturbance associated with conventional forest management in Central Europe reduces the species richness of epiphytic cryptogams in comparison to primeval forests, while the richness of vascular plants on the forest floor is not negatively affected. When categorizing conventional beech forest management as a disturbance of intermediate intensity, this finding supports the first part our hypothesis (1) which postulated 
that the bryophyte and lichen diversity patterns in Fagus sylvatica forests do not fit to IDH. We interpret this outcome as an indication that the management intensity in Slovakian production forests is already higher than the disturbance level which would promote the diversity of epiphytic bryophytes and lichens in natural beech forests. Since the Slovakian beech production forests are affected by logging activities only at the end of the production cycle, management intensity is certainly lower than in many beech forests in other Central or Western European countries, where thinning operations are conducted regularly.

Rose (1992) postulated with reference to the known habitat preferences of forest-inhabiting bryophytes and lichens that, in natural forests, the structural dynamics, that are generated by the ageing of trees and the forest development cycle and caused by certain external disturbance events, might promote the species richness of forest cryptogams, for example, by increasing light availability after gap formation and by processes leading to dead-wood accumulation. Such disturbances are inherent elements of the natural dynamics of old-growth forests and the microhabitat heterogeneity created and maintained by these disturbances seems to be one cause of the large species pool of epiphytic bryophytes and lichens found in these systems.

Natural disturbances promote habitat heterogeneity in the forest (Swanson et al. 2011), which increases species richness, while anthropogenic disturbances often are more regular in space and time, and their effect on diversity is mixed, depending on intensity. Any human alteration of forest structure in F. sylvatica forests, which is of higher intensity than the natural disturbance regime, seems to result in a switch of the disturbance effect on bryophyte and lichen diversity from a positive to a negative impact. This is evidenced by the contrast of managed and unmanaged forests as mentioned above (e.g. Dettki \& Esseen 1998; Friedel et al. 2006; Vellak \& Ingerpuu 2005) and by comparing forests with different management intensities (Aragon et al. 2010; Hofmeister et al. 2015; Király et al. 2013), which demonstrated a negative impact of forest management on the bryophyte and lichen diversity of various forest ecosystems. Jonsson and Esseen (2016) stated that bryophyte species with high sensitivity to competition colonize preferentially bare soil generated by uprooted trees, a habitat which is usually lacking in production forests (Bartels \& Chen 2010). Patches with disturbed topsoil are also generated by selective logging activities, but these sites will be covered by closed litter layers in autumn, thereby excluding many bryophytes, in contrast to the often more exposed and thus bare root plates in primeval forests. 


\section{Conclusion}

Without doubt, true primeval forests with long continuity of natural disturbance regimes are not only storing impressive amounts of biomass and carbon, they are also of outstanding value for the conservation of temperate forest biodiversity, which cannot be achieved by any form of low-impact forestry. In contrast to widespread belief, this seems also to be valid for the typical vascular flora of temperate forests, which requires a sufficiently large area of unmanaged forest to survive. Arguments that forestry can increase biodiversity by reducing beech dominance and

increasing tree species diversity (e.g. Schulze et al. 2016) make sense when applied to production forests, but such measures can in no way be an alternative to setting aside sufficiently large old-growth forest reserves in order to protect the core of species that are dependent on the characteristic microhabitats of true primeval forests. Continuous forest management operations, as are practiced in most Central European forests, do not only increase the disturbance level substantially, but they also markedly reduce the structural complexity, which characterizes old-growth forests and drives species richness. This increases the gap in epiphyte species richness relative to primeval forests, and it may also result in the long-term decrease of vascular plant species richness in production stands (Härdtle 1994), as typical specialist forest taxa are increasingly replaced by species with broader ecological niche, that tolerate higher disturbance levels, disperse more rapidly and often are more competitive. Therefore, the last primeval forest relicts in Europe and elsewhere in the temperate zone are not only indispensable for preserving the biological diversity of these forests; they are also highly needed objects for studying the role of structural heterogeneity in forest dynamics, productivity and stability.

\section{Acknowledgements}

This study was funded by the Stemmler Foundation, a member of the Stifterverband für die Deutsche Wissenschaft. We are grateful to the Poloniny National Park administration, the Ministry of Defense of the Slovak Republic for the permission to conduct the study, and to the Technical University of Zvolen for field support. Special thanks go to Alan Orange (Cardiff), André Aptroot (Soest), Alfons Schäfer-Verwimp (Herdwangen-Schönach), Christian Printzen (Frankfurt), Matthias Schultz (Hamburg), Michael Lüth (Freiburg), Begona Aguirre-Hudson (Richmond), Leif Tibell (Uppsala), Othmar Breuss (Vienna) and Tor Tønsberg (Bergen) for the confirmation of critical species. 


\subsection{Appendix}

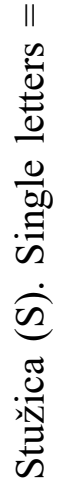

Q

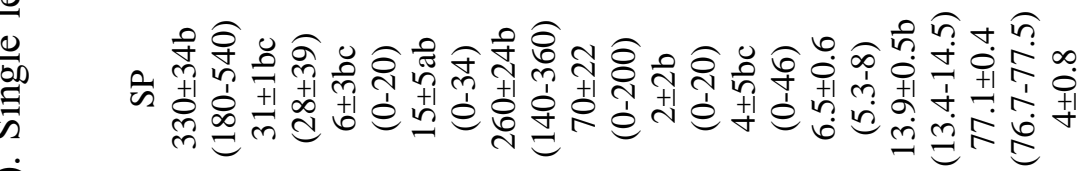

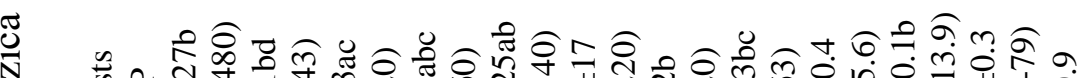

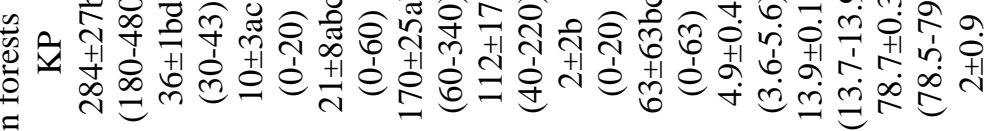

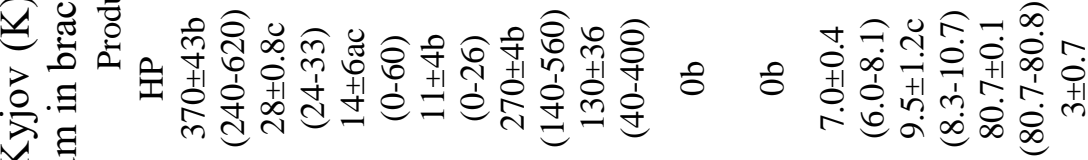

画

⿷匚⿳丨コ丨

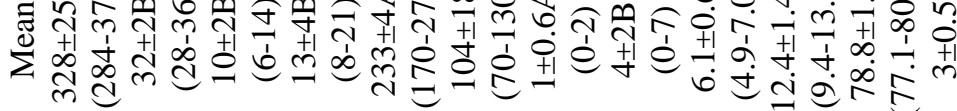

究

寈夆

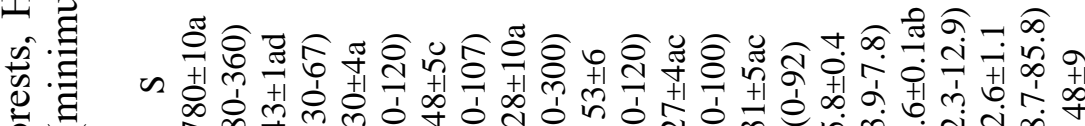

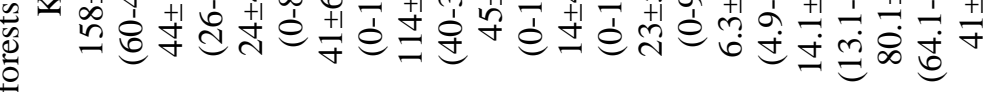

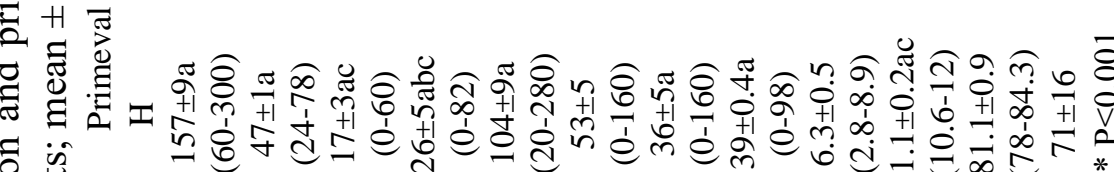

चี

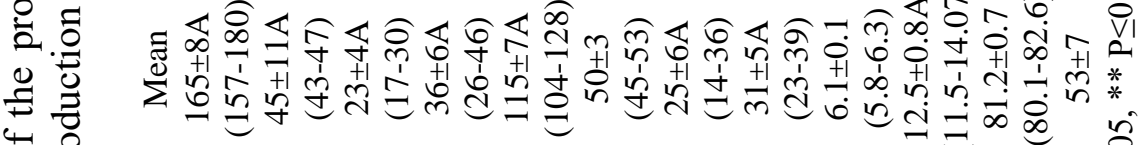

फे

幽

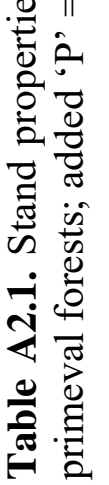

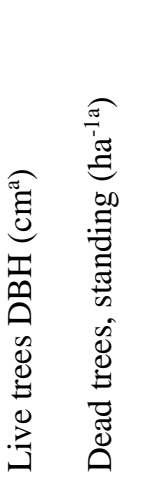

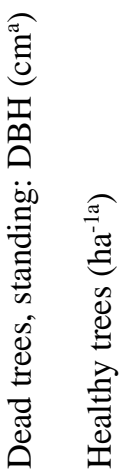

है viv 
Table A2.2. Total species numbers occurring in each three primeval $(\mathrm{N}=40)$ plots and production forest ( $\mathrm{N}=10$ plots).

\begin{tabular}{lcccccc}
\hline Sites & H & K & S & HP & KP & SP \\
\hline Bryophytes & 60 & 52 & 73 & 32 & 33 & 35 \\
Mosses & 51 & 46 & 61 & 28 & 27 & 30 \\
Liverworts & 9 & 6 & 16 & 4 & 6 & 5 \\
Lichens & 61 & 39 & 54 & 23 & 16 & 14 \\
$\begin{array}{l}\text { Vascular } \\
\text { plants }\end{array}$ & 31 & 43 & 36 & 31 & 32 & 30 \\
\hline
\end{tabular}

In total, 50 vascular plants, 65 mosses (plus one variety), 17 liverworts, and 82 lichen species (plus three non-lichenized fungi, i.e. Chaenothecopsis pusilla, C. pusiola and Mycocalicium subtile) were found in the three primeval beech forests (each 40 sample plots). The three production stands (each 10 sample plots) harboured 43 vascular plants, 42 mosses (plus one variety), six liverworts and 33 lichen species. 


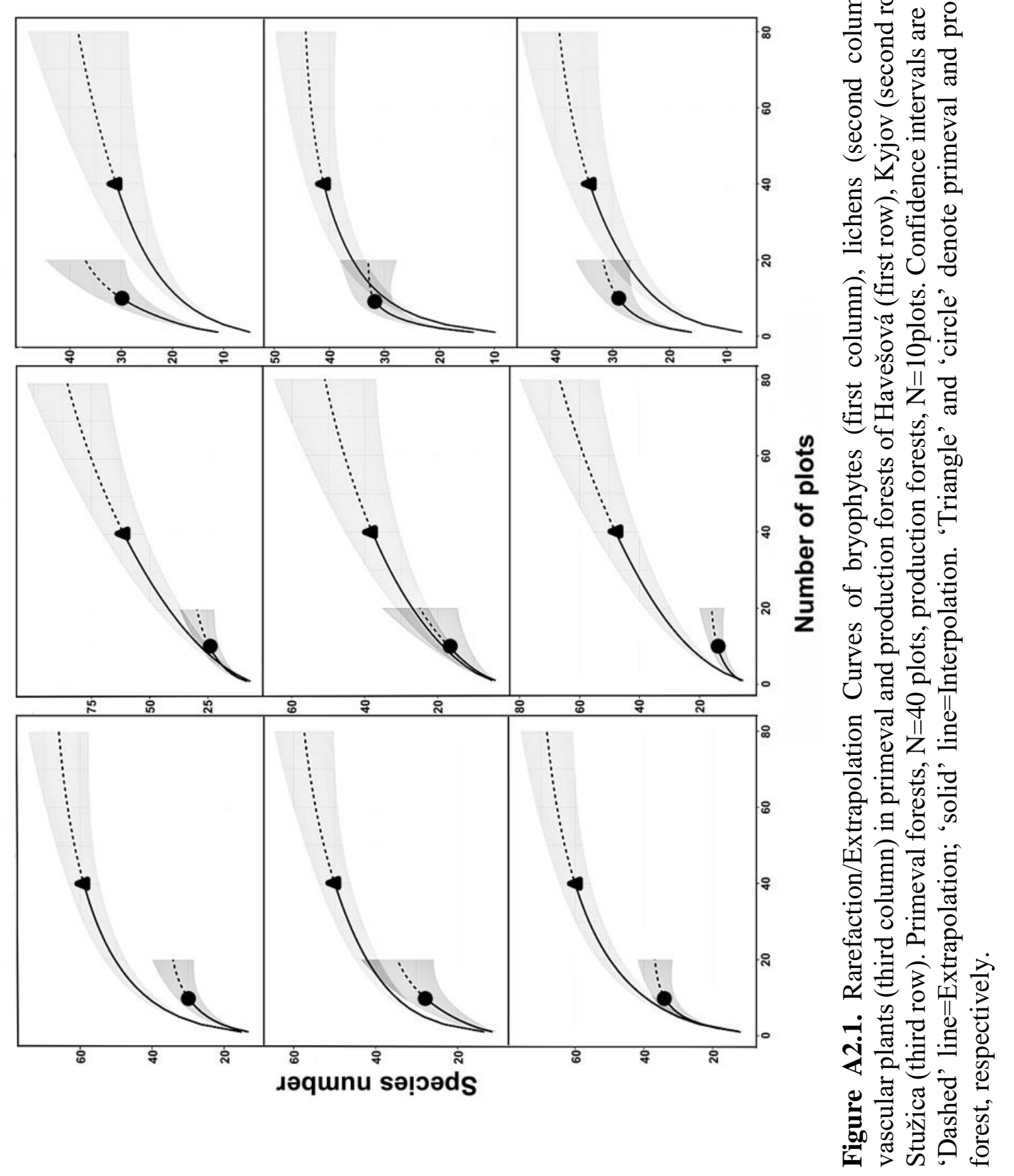



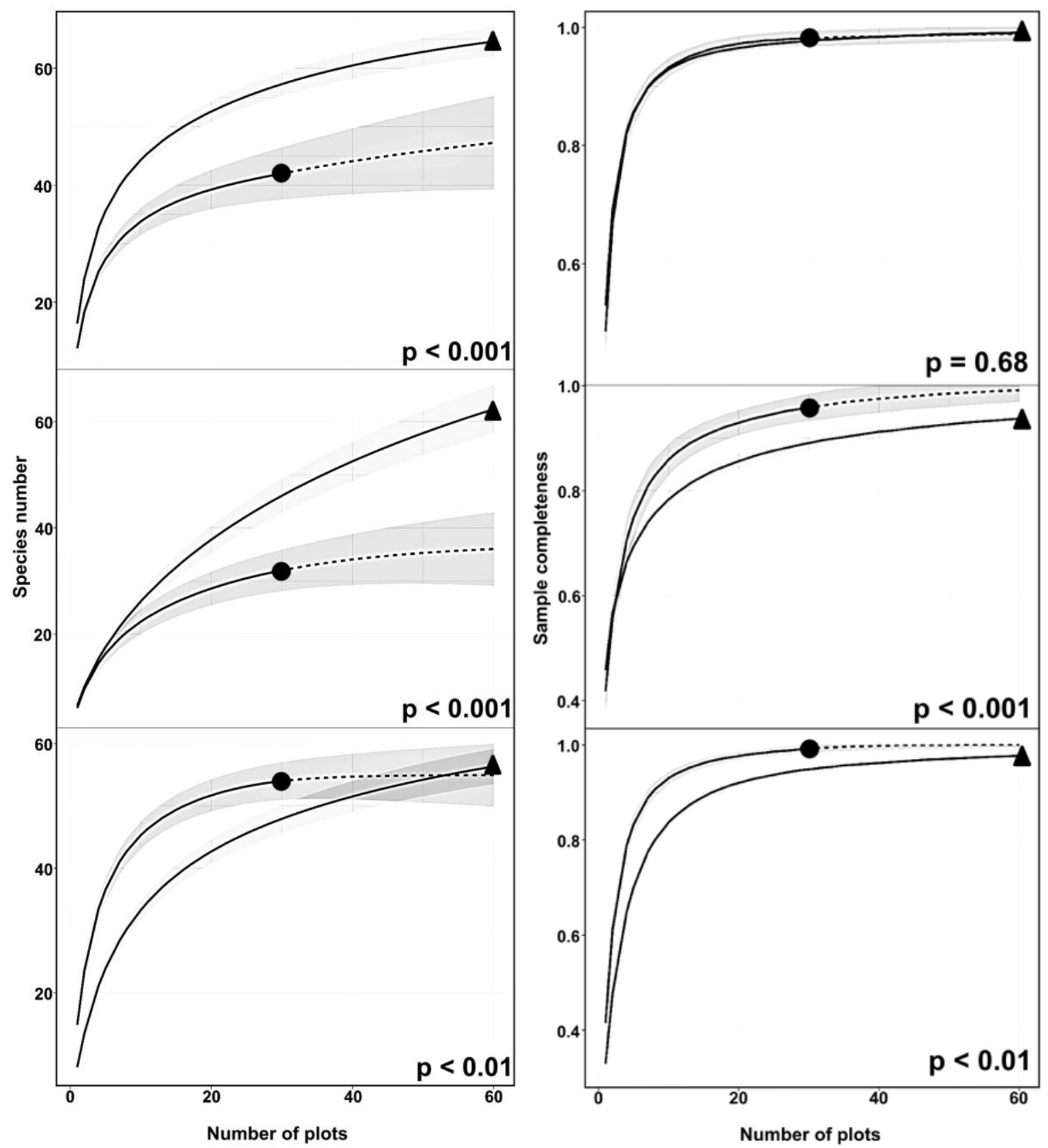

Figure A2.2. Rarefaction/extrapolation curves (left column) and sample-completeness curves (right column) for bryophytes (first row), lichens (second row) and vascular plants (third row) in the primeval and production forests. The species numbers and the sample-completeness of the three study areas (Havešová, Kyjov and Stužica) were added (y-axes have different scaling in case of the sample-completeness curves). Confidence intervals are shaded. The number of plots was extrapolated to the doubled reference sample size $(\mathrm{N}=60)$. Nboot $=1000$. 'Dashed' line = extrapolation; 'solid' line $=$ interpolation. 'Triangle' and 'circle' denote primeval and production forest, respectively.

Statistics: Kruskal-Wallis test, ${ }^{*} \mathrm{P} \leq 0.05,{ }^{*} * \mathrm{P} \leq 0.01,{ }^{*} * \mathrm{P} \leq 0.001$ 


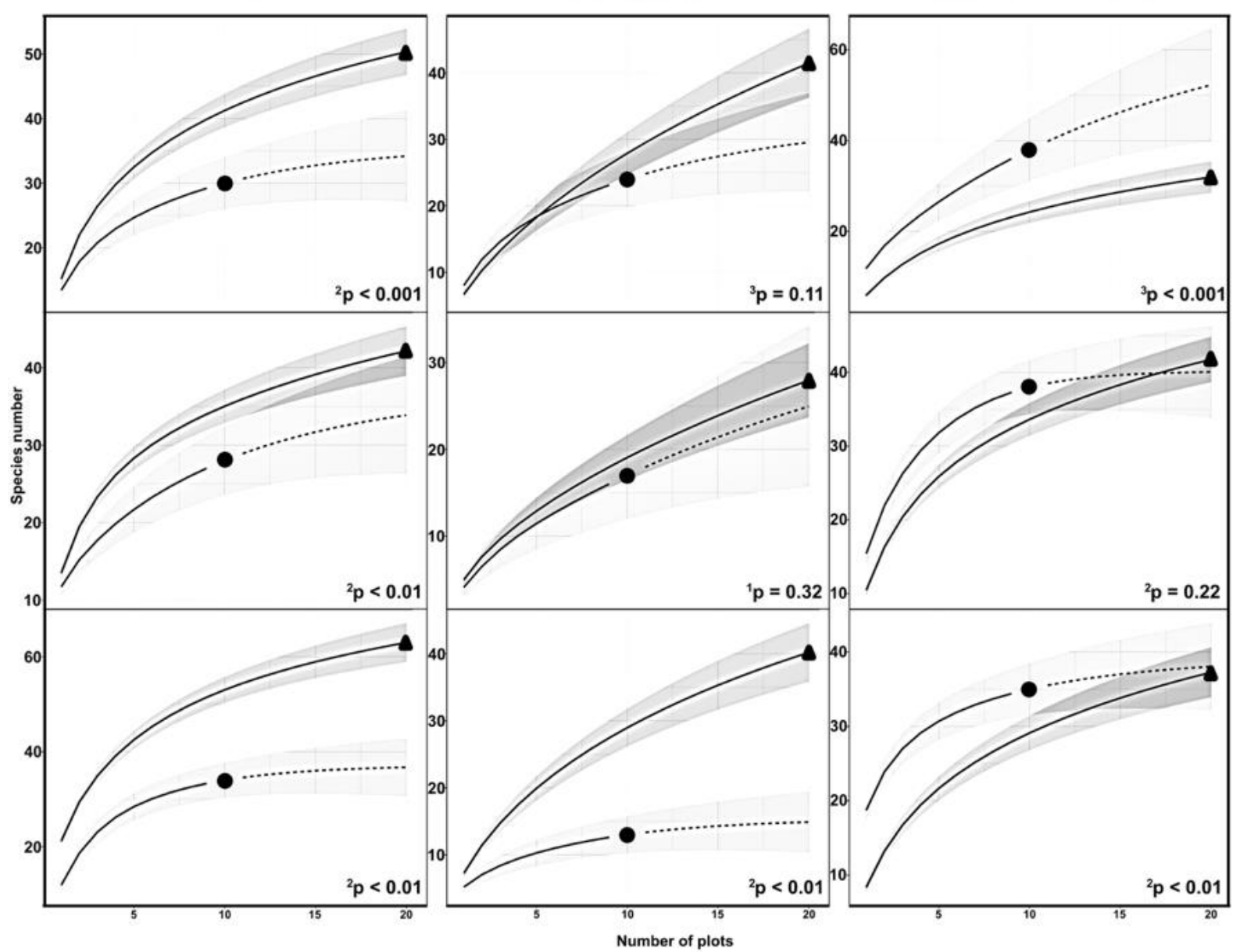

Figure A2.3. Rarefaction/extrapolation curves of bryophytes (left column), lichens (middle column) and vascular plants (right column) in primeval and production forests of Havešová (first row), Kyjov (second row) and Stužica (third row). Primeval forests, $\mathrm{N}=20$ plots, production forests, $\mathrm{N}=10$ plots (extrapolated to the doubled reference sample size). Confidence intervals are shaded. Nboot $=1000$. 'Dashed' line $=$ extrapolation; 'solid' line $=$ interpolation. 'Triangle' and 'circle' denote primeval and production forest, respectively.

${ }^{1}$ Statistics: ANOVA, $* \mathrm{P} \leq 0.05, * * \mathrm{P} \leq 0.01, * * * \mathrm{P} \leq 0.001$

${ }^{2}$ Statistics: Kruskal-Wallis test, ${ }^{*} \mathrm{P} \leq 0.05, * * \mathrm{P} \leq 0.01, * * * \mathrm{P} \leq 0.001$

${ }^{3}$ Statistics: Welch's F-Test, $* \mathrm{P} \leq 0.05,{ }^{*} * \mathrm{P} \leq 0.01, * * * \mathrm{P} \leq 0.001$ 


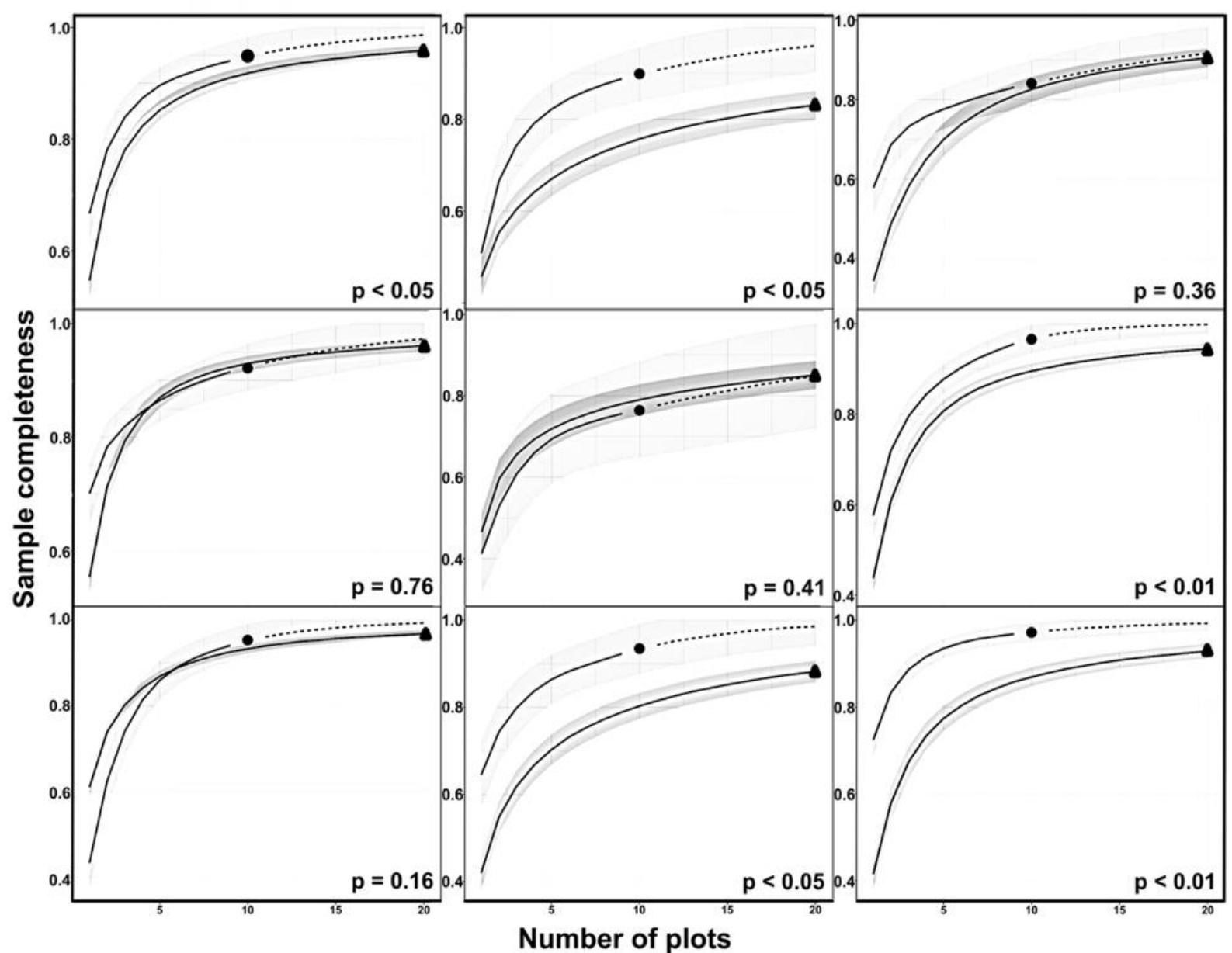

Figure A2.4. Sample-completeness curves of epiphytic bryophytes (left column), lichens (middle column) and vascular plants (right column) in primeval and production forests of Havešová (first row), Kyjov (second row) and Stužica (third row). Primeval forests, N=20 plots, production forests, $\mathrm{N}=10$ plots (extrapolated to the doubled reference sample size). Confidence intervals are shaded. Nboot $=1000$. 'Dashed' line $=$ extrapolation; 'solid' line $=$ interpolation. 'Triangle' and 'circle' denote primeval and production forest, respectively.

Statistics: Kruskal-Wallis test, $* \mathrm{P} \leq 0.05, * * \mathrm{P} \leq 0.01$, *** $\mathrm{P} \leq 0.001$ 


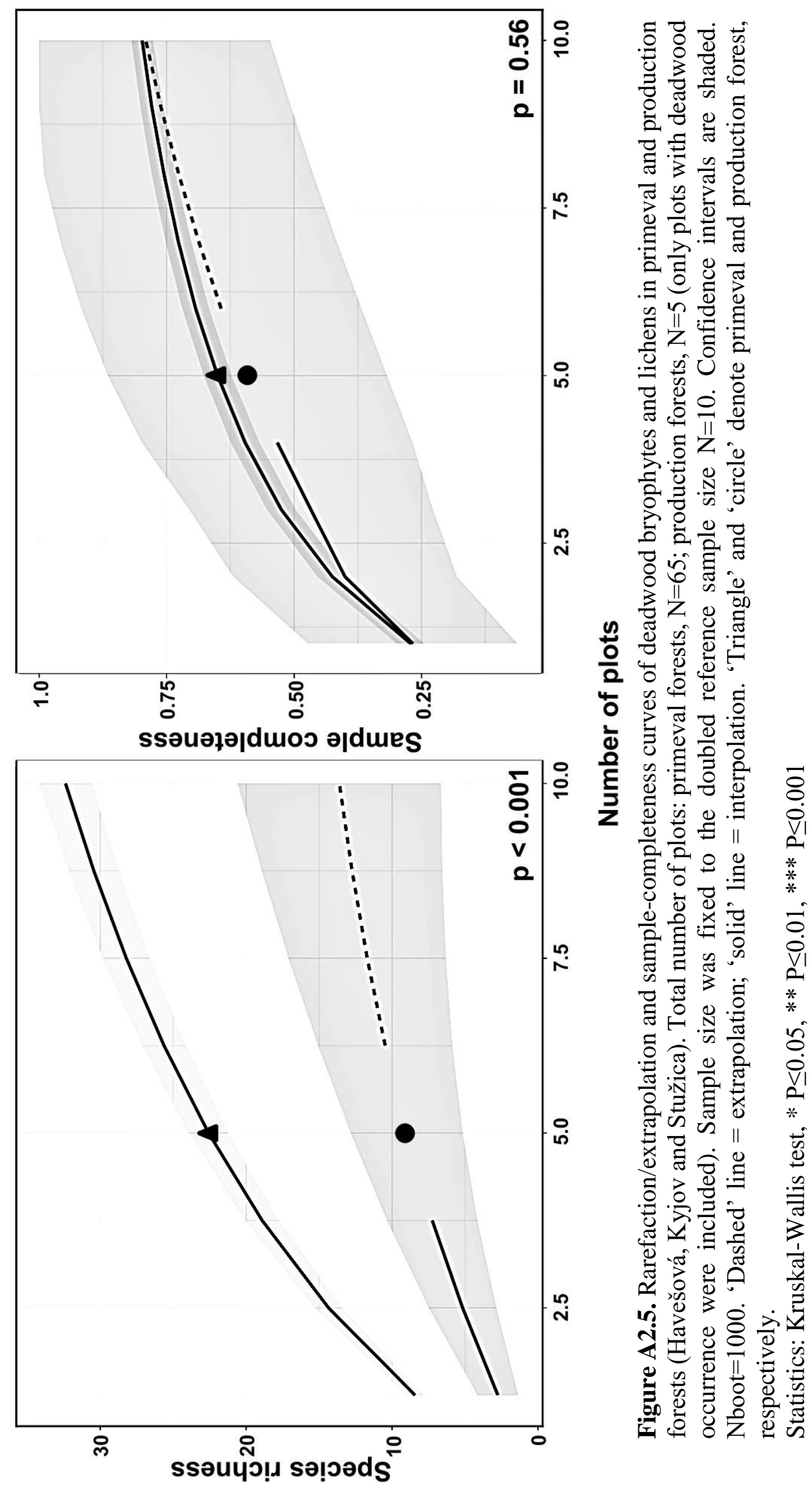


We computed additional rarefaction/extrapolation and sample-completeness curves of bryophyte, lichen and vascular plant species richness for a defined sample size 10 plots (extrapolated to 20 plots) to equalize the unbalanced sampling design (Figures A 2.2-A 2.5). We used bootstrapping $($ Nboot=1000) and randomly selected 10 plots in each primeval forest. Rarefaction/Extrapolation curves: For the bryophyte, lichen and vascular plant species richness, the results obtained from the curves with a defined sample size correspond well with those with the original unbalanced approach (stands pooled: Fig. 2.2, stands separated: Fig. A2.1). Plotting species numbers of deadwood bryophytes and lichens against plot numbers revealed a significantly higher number of species in the primeval forests (Fig. A 2.5).

Sample-completeness curves: The bryophyte species pool was better detected by sampling the 20 plots in the production forests than in the primeval forests in Havešová (difference significant), but not in Kyjov and Stužica. For the lichen species pool, this was the case in Havešová and Stužica (differences significant), and for the vascular plant species pool in Kyjov and Stužica (difference significant; Fig. A 2.4). For deadwood bryophytes and lichens, samplecompleteness did not differ between the two forest types (Fig. A 2.5).

\section{References}

Aragon, G., Martínez, I., Izquierdo, P., Belinchón, R. \& Escudero, A. (2010). Effects of forest management on epiphytic lichen diversity in Mediterranean forests. Applied Vegetation Science, 13, 183-194.

Aude, E. \& Poulsen, R.S. (2000). Influence of management on the species composition of epiphytic cryptogams in Danish Fagus forests. Applied Vegetation Science, 3, 81-88.

Bače, R., Svoboda, M., Pouska, V., Janda, P. \& Červenka, J. (2012). Natural regeneration in Central-European spruce forests: which logs are suitable for seedling recruitment? Forest Ecology and Management, 266, 254-262.

Barbier, S., Gosselin, F. \& Balandier, P. (2008). Influence of tree species on understory vegetation diversity and mechanisms involved. A critical review for temperate and boreal forests. Forest Ecology and Management, 254, 1-15.

Bardat, J. \& Aubert, M. (2007). Impact of forest management on the diversity of corticolous bryophyte assemblages in temperate forests. Biological Conservation, 139, 47-66.

Bartels, S.F. \& Chen, H.Y.H. (2010). Is understory plant species diversity driven by resource quantity or resource heterogeneity? Ecology, 91, 1931-1938. 
Baselga, A., Orme, D., Villeger, S., Bortoli, J. De \& Leprieur, F. (2015). betapart: Partitioning beta diversity into turnover and nestedness components. R Packag. Version 1.3, 1-26.

Bengtsson, J., Nilsson, S.G., Franc, A. \& Menozzi, P. (2000). Biodiversity, disturbances, ecosystem function and management of european forests. Forest Ecology and Management, 132, 39-50.

Boch, S., Prati, D., Hessenmöller, D., Schulze, E.D. \& Fischer, M. (2013a). Richness of Lichen Species, Especially of Threatened Ones, Is Promoted by Management Methods Furthering Stand Continuity. PLoS ONE 81.

Boch, S., Prati, D., Müller, J., Socher, S., Baumbach, H. \& Buscot, F. (2013b). High plant species richness indicates management-related disturbances rather than the conservation status of forests. Basic Applied Ecology, 14, 496-505.

Bremer, L.L. \& Farley, K.A. (2010). Does plantation forestry restore biodiversity or create green deserts? A synthesis of the effects of land-use transitions on plant species richness. Biodiversity and Conservation, 19, 3893-3915.

Brunet, J., Falkengren-Grerup, U. \& Tyler, G. (1996). Herb layer vegetation of south Swedish beech and oak forests - Effects of management and soil acidity during one decade. Forest Ecology and Management, 88, 259-272.

Brunet, J., Fritz, Ö. \& Richnau, G. (2010). Biodiversity in European beech forests - a review with recommendations for sustainable forest management. Ecological Bulletins, 53, 7794.

Bunnell, F.L. \& Houde, I. (2010). Down wood and biodiversity - implications to forest practices. Environmental Reviews, 18, 397-421.

Chao, A., Gotelli, N.J., Hsieh, T.C., Sander, E.L., Ma, K.H. \& Colwell, R.K. (2014). Rarefaction and extrapolation with Hill numbers: A framework for sampling and estimation in species diversity studies. Ecological Monographs, 84, 45-67.

Chen, J., Saunders, S. \& Crow, T. (1999). Landscape variations in local climate can be used to monitor and compare the effects of different management regimes. Bioscience, 49, 288297.

Clarke, K.R. (1993). Non-parametric multivariate analyses of changes in community structure. Australian Journal of Ecology, 18, 117-143. 
Colwell, R.K., Chao, A., Gotelli, N.J., Lin, S.Y., Mao, C.X. \& Chazdon, R.L. (2012). Models and estimators linking individual-based and sample-based rarefaction, extrapolation and comparison of assemblages. Journal of Plant Ecology, 5, 3-21.

Connell, J.H. (1978). Diversity in tropical rainforests and coral reefs. Science, 199, 1302-1310.

Crist, T.O. \& Veech, J.A. (2006). Additive partitioning of rarefaction curves and species-area relationships: Unifying $\alpha$-, $\beta$ - and $\gamma$-diversity with sample size and habitat area. Ecology Letters, 9, 923-932.

Crow, T.R., Buckley, D.S., Nauertz, E.A. \& Zasada, J.C. (2002). Effects of management on the composition and structure of northern hardwood forests in upper Michigan. Forest Science, 48, 129-145.

Decocq, G., Aubert, M., Dupont, F., Alard, D., Saguez, R., Wattez-Franger, A., De Foucault, B., Delelis-Dusollier, A. \& Bardat, J. (2004). Plant diversity in a managed temperate deciduous forest: Understorey response to two silvicultural systems. Journal of Apllied Ecology, 41, 1065-1079.

Danihelka, J., Chrtek, J. \& Kaplan, Z. (2012). Checklist of vascular plants of the Czech Republic. Preslia, 84, 647-811.

Degen, T., Devillez, F. \& Jacquemart, A.L. (2010). Gaps promote plant diversity in beech forests Luzulo-Fagetum, North Vosges, France. Silvae Genetetica, 59, 175-182.

Dettki, H. \& Esseen, P.-A. (1998). Epiphytic macrolichens in managed and natural forest landscapes: a comparison at two spatial scales. Ecography, 21, 613-624.

Dittrich, S., Hauck, M., Jacob, M., Rommerskirchen, A. \& Leuschner, C. (2013). Response of ground vegetation and epiphyte diversity to natural age dynamics in a Central European mountain spruce forest. Journal of Vegetation Science, 24, 675-687.

Dörfelt, H. (2007). Biodiversität von Buchenwäldern unter mykologischen Gesichtspunkten. Bfn-Skripten Bonn-Bad Godesberg, 222, 91-93.

Dorow, W.H.O., Kopelke, J.-P. \& Flechtner, G. (2007). Wichtigste Ergebnisse aus 17 Jahren zoologischer Forschung in hessischen Naturwaldreservaten. Forstarchiv, 78, 215-222.

Dymytrova, L., Nadyeina, O., Hobi, M.L. \& Scheidegger, C. (2014). Topographic and foreststand variables determining epiphytic lichen diversity in the primeval beech forest in the Ukrainian Carpathians. Biodiversity and Conservation, 23, 1367-1394. 
Ellenberg, H. \& Leuschner, C. (2010). Vegetation Mitteleuropas mit den Alpen in ökologischer, dynamischer und historischer Sicht, 6th edn. Ulmer, Stuttgart.

Elix, J. A., Kalb K., Rupprecht J. \& Schobert, R. (2012). LIAS metabolites - A Database for the Rapid Identification of Secondary Metabolites of Lichens ed. Rambold, G. liaslight.lias.net/Identification/Navikey/Metabolites/.

Friedel, A., Oheimb, G. V., Dengler, J. \& Härdtle, W. (2006). Species diversity and species composition of epiphytic bryophytes and lichens - A comparison of managed and unmanaged beech forests in NE Germany. Feddes Repertorium, 117, 172-185.

Fritz, Ö., Niklasson, M. \& Churski, M. (2009). Tree age is a key factor for the conservation of epiphytic lichens and bryophytes in beech forests. Applied Vegetation Science, 12, 93106.

Fritz, Ö., Gustafsson, L. \& Larsson, K. (2008). Does forest continuity matter in conservation? - A study of epiphytic lichens and bryophytes in beech forests of southern Sweden. Biological Conservation, 141, 655-668.

Gilliam, F.S. (2014). The Herbaceous Layer in Forests of Eastern North America. 2nd ed. Oxford Univ. Press, Oxford.

Guttova, A., Lackovicová, A. \& Pisút, I. (2013). Revised and updated checklist of lichens of Slovakia. Biologia, 68, 845-850.

Halme, P., Toivanen, T., Honkanen, M., Kotiaho, J.S., Mönkkönen, M. \& Timonen, J. (2010). Flawed meta-analysis of biodiversity effects of forest management. Conservation Biology, 24, 1154-1156.

Halpern, C.B. \& Spies, T.A. (2008). Plant species diversity in natural and managed forests of the Pacific Northwest. Ecological Applications, 5, 913-934.

Härdtle, W. (1994). Zur Veränderung der Schutzfähigkeit historisch alter Wälder in SchleswigHolstein. NNA-Berichte Schneverdingen, 3, 88-96.

Hauck, M. (2011). Site factors controlling epiphytic lichen abundance in northern coniferous forests. Flora, 206, 81-90.

Hedderson, T.A. (1992). Rarity at range limits; dispersal capacity and habitat relationships of extraneous moss species in a boreal Canadian National Park. Biological Conservation, 59, 113-120. 
Hilmo, O. \& Såstad, S.M. (2001). Colonization of old-forest lichens in a young and an old boreal Picea abies forest: an experimental approach. Biological Conservation, 102, 251259.

Hilmo, O. (2002). Growth and morphological response of old-forest lichens transplanted into a young and an old Picea abies forest. Ecography, 25, 329-335.

Hodgetts, N. (2015). Checklist and country status of European bryophytes - towards a new Red List for Europe. Irish Wildl. Manuals, 84. National Parks and Wildlife Service, Department of Arts, Heritage and the Gaeltacht, Ireland.

Hofmeister, J., Hošek, J., Holá, E. \& Novozámská, E. (2015). Decline in bryophyte diversity in predominant types of central European managed forests. Biodiversity and Conservation, 24, 1391-1402.

Hsieh, T.C., Ma, K.H. \& Chao, A. (2015). R-Package "iNEXT.”

Jonsson, B.G., Kruys, N. \& Ranius, T. (2005). Ecology of species living on dead wood Lessons for dead wood management. Silva Fennica, 39, 289-309.

Jonsson, B.G. \& Esseen, P. (2016). Treefall Disturbance Maintains High Bryophyte Diversity in a Boreal Spruce Forest. British Ecological Society Stable URL: http://www.jstor.org/stable/2260943. Accessed : 16-06-2016

Kelemen, K., Mihók, B., Galhidy, L. \& Standovár, T. (2012). Dynamic response of herbaceous vegetation to gap opening in a central European beech stand. Silva Fennica, 46, 53-65.

Kaplan, J.O., Krumhardt, K.M. \& Zimmermann, N. (2009). The prehistoric and preindustrial deforestation of Europe. Quaternary Science Reviews, 28, 3016-3034.

Király, I., Nascimbene, J., Tinya, F. \& Ódor, P. (2013). Factors influencing epiphytic bryophyte and lichen species richness at different spatial scales in managed temperate forests. Biodiversity and Conservation, 22, 209-223.

Korpel, S. (1995). Die Urwälder der Westkarpathen. Fischer Verlag, Stuttgart.

Larrieu, L., Cabanettes, A. \& Delarue, A. (2012). Impact of silviculture on dead wood and on the distribution and frequency of tree microhabitats in montane beech-fir forests of the Pyrenees. European Journal of Forest Research, 131, 773-786.

Lesica, P., McCune, B., Cooper, S.V. \& Hong, W.S. (1991). Differences in lichen and bryophyte communities between old-growth and managed second-growth forests in the Swan Valley, Montana. Canadian Journal of Botany, 69, 1745-1755. 
Leuschner, C. \& Lendzion, J. (2009). Air humidity, soil moisture and soil chemistry as determinants of the herb layer composition in European beech forests. Journal of Vegetation Science, 20, 288-298.

Lonsdale, D., Pautasso, M. \& Holdenrieder, O. (2008). Wood-decaying fungi in the forest: Conservation needs and management options. European Journal of Forest Research, 127, $1-22$.

Marušá, R. (2007). Alternative harvest scheduling for final cut with respect to silvicultural requirements. Forstwissenschaftliches Centralblatt vereinigt mit Tharandter forstliches Jahrbuch, 121, 301-321.

MASR (2009). Report on Forestry in the Slovak Republik 2009 Green Report. Zvolen.

McCune, B. \& Mefford, M.J. (2006). PC-ORD: Multivariate Analysis of Ecological Data. Version 5.14. MjM Software, Gleneden Beach, Oregon, U.S.A.

Moning, C., Werth, S., Dziock, F., Bässler, C., Bradtka, J. \& Hothorn, T. (2009). Lichen diversity in temperate montane forests is influenced by forest structure more than climate. Forest Ecology and Management, 258, 745-751.

Müller, J., Boch, S. \& Blaser, S. (2015). Effects of forest management on bryophyte communities on deadwood. Nova Hedwigia, 100, 423-438.

Nascimbene, J., Marini, L. \& Nimis, P.L. (2007). Influence of forest management on epiphytic lichens in a temperate beech forest of northern Italy. Forest Ecology and Management, 247, 43-47.

Nascimbene, J., Thor, J. \& Nimis, P.L. (2013). Effects of forest management on epiphytic lichens in temperate deciduous forests of Europe - A review. Journal of Chemical Information and Modeling, 53, 1689-1699.

Neuhäusl, R., Dierschke, H. \& Barkman, J.J. (1982). Chorological phenomena in plant communities: Proceedings of 26th International Symposium of the International Association for Vegetation Science, Prague, Czech Republic.

National Forest Centre (2009). Forests in Slovakia. - Ministry of agriculture of the Slovak Republic, Bratislava.

Ódor, P., Kiraly, I., Tinya, F., Bortignon, F. \& Nascimbene, J. (2014). Reprint of: Patterns and drivers of species composition of epiphytic bryophytes and lichens in managed temperate forests. Forest Ecology and Management, 321, 42-51. 
Ódor, P., Dort, K. Van, Aude, E., Heilmann-Clausen, J. \& Christensen, M. (2005). Diversity and Composition of Dead Wood Inhabiting. Boletín Soc. Española Briología, 26-27, 85102.

Ódor, P. \& Standovár, T. (2001). Richness of bryophyte vegetation in near-natural and managed beech stands: the effects of management-induced differences in dead wood. Ecological Bulletin, 49, 219-229.

Ódor, P. \& van Hees, A.F.M. (2004). Preferences of dead wood inhabiting bryophytes for decay stage, log size and habitat types in Hungarian beech forests. Journal of Bryology, 26, 79 95.

Orange, A., James, P.W. \& White, F.J. (2001). Microchemical methods for the identification of lichens. British Lichen Society. London. 101pp.

Paillet, Y., Bergès, L., Hjältén, J., Ódor, P., Avon, C. \& Bernhardt-Römermann, M. (2010). Biodiversity differences between managed and unmanaged forests: Meta-analysis of species richness in Europe. Conservation Biology, 24, 101-112.

Rose, F. (1992). Temperate forest management: its effects on bryophyte and lichen floras and habitats. 211-233. In Bates, J.W. \& Farmer, A.M., (eds.). Bryophytes and Lichens in a Changing Environment. Clarendon, Oxford, UK.

RStudio Team (2015). Integrated Development for R. RStudio, Inc., Boston, MA.

Scheller, R.M. \& Mladenoff, D.J. (2002). Understory species patterns and diversity in oldgrowth and managed northern hardwood forests. Ecological Applications, 12, 13291343.

Schulze, E.D., Aas, G., Grimm, G.W., Gossner, M.M., Walentowski, H. \& Ammer, C. (2016). A review on plant diversity and forest management of European beech forests. European Journal of Forest Research, 135, 51-67.

Sillett, S.C., McCune, B., Peck, J.E., Rambo, T.R. \& Rutchy, A. (2000). Dispersal limitations of epiphytic lichens result in species dependent on old-growth forests. Ecological Applications, 10, 789-799.

Slezák, M., Hrivnák, R., Ujházy, K., Ujházyyová, M., Máliš, F. \& Petrášová, A. (2016). Syntaxonomy and ecology of acidophiluos beech forest vegetation in Slovakia. Phytocoenologia, 46, 69-88. 
Swanson, M. E., Franklin, J. F., Beschta, R. L., Crisafulli, Ch. M., DellaSala, D. A., Hutto, R. L., Lindenmaver, D. B. \& Swanson, F. J. (2011). The Forgotten Stage of Forest Succession: Early-Successional Ecosystems on Forest Sites. Biological Sciences Faculty Publications. Paper 278.

Tinya, F., Márialigeti, S., Király, I., Németh, B. \& Ódor, P. (2009). The effect of light conditions on herbs, bryophytes and seedlings of temperate mixed forests in Western Hungary. Plant Ecolology, 204, 69-81.

Vellak, K. \& Ingerpuu, N. (2005). Management effects on bryophytes in Estonian forests. Biodiversity Conservation, 14, 3255-3263.

Vološčuk, I. (2014). Joint Slovak-Ukraine-Germany Beech Ecosystems as the World Natural Heritage. Ekologia, 33, 286-300.

von Oheimb, G., Friedel, A., Tempel, H., Westphal, C. \& Härdtle, W. (2004). Untersuchungen zur Struktur und zur Moos- und Flechtenflora in unbewirtschafteten und bewirtschafteten Buchenwäldern des Nordostdeutschen Tieflandes. Beiträge für Forstwirtschaft und Landschaftsökologie, 38, 81-86.

Wagner, S., Fischer, H. \& Huth, F. (2011). Canopy effects on vegetation caused by harvesting and regeneration treatments. European Journal of Forest Research, 130, 17-40. 


\section{Chapter 3}

Effects of natural forest dynamics on vascular plant, bryophyte, and lichen diversity in primeval Fagus sylvatica forests and comparison with production forests
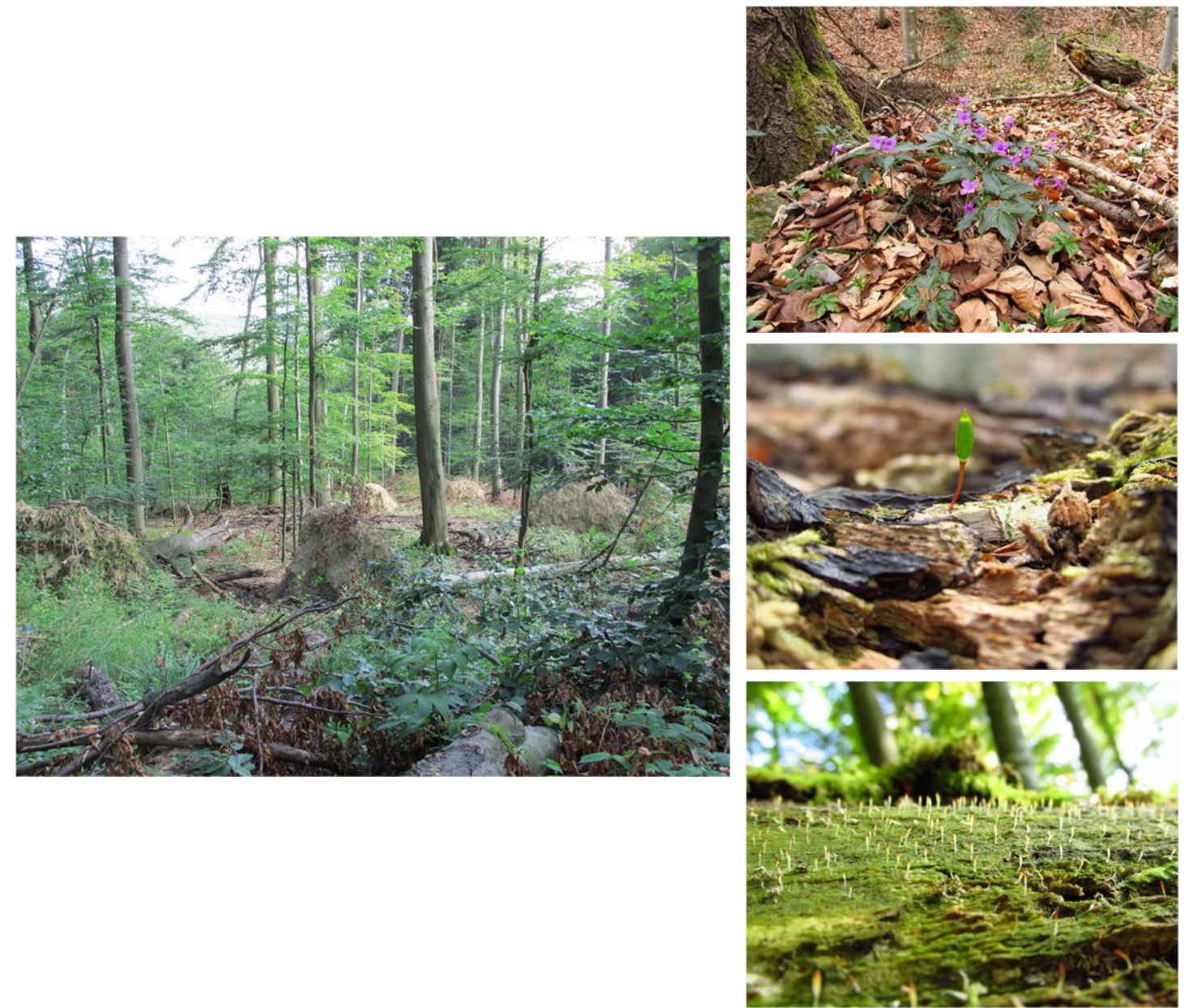

Stefan Kaufmann, Markus HaucK \& Christoph Leuschner Journal of Ecology, 2018, Vol. 106(6), 2421-2434. 


\section{Summary}

1. Stand structure, mean tree age, deadwood amount and microclimate all change markedly in the course of natural forest dynamics. The last remaining primeval forests of the temperate forest biome are valuable study objects to investigate the effects of forest dynamics and management on forest structure and function as well as phytodiversity, which is not sufficiently understood.

2. Three pairs of Fagus sylvatica primeval and production forests in eastern Slovakia were selected for studying the effects of natural forest development stages on vascular plant, bryophyte, and lichen species richness and composition. We further compared the diversity patterns in the initial, optimal and terminal stages of forest development with those of nearby production forests.

3. The plot-level species richness of epiphytic bryophytes and lichens increased from the initial to the terminal stage, but only lichens exhibited a significantly higher cumulative species richness ( $\gamma$ diversity) in the later (optimal and terminal) stages. No increase in species richness from the initial to the terminal stage was found for deadwood-inhabiting epiphytes and the ground-layer vascular plants. Canonical correspondence analyses identified characteristic bryophyte and lichen species for the different development stages, while the bulk of vascular ground layer species occurred across all stages with no stage preference.

4. Stem diameter was an even more important driver of epiphyte diversity and species composition than the development stage. All stages of the primeval forests (including the initial) were more species-rich in epiphytes and, when investigating larger plot numbers, also in vascular plants than the production forests.

5. Synthesis. In primeval forests of European beech, plant species richness did not differ significantly between the consecutive forest development stages, while species composition did. This is attributable to the smal-scale mosaic structure of the forest, rapid gap closure by beech, and the continuity of deadwood across the stages, which reduces spatio-temporal differences in microhabitat availability in the forest. Bryophytes and lichens are species-richer, and vascular plants at least similarly rich, in the primeval as compared to the production forests, if the study area is sufficiently large.

Key words: bryophytes, Fagus sylvatica, forest development stages, forest management, habitat heterogeneity, lichens, primeval forests, vascular plants 


\subsection{Introduction}

The role of tree ageing and natural disturbance regimes for forest structure, biodiversity and ecosystem functioning has attracted considerable attention in the recent past (Franklin et al. 2002; Kuuluvainen 2009). The marked structural and compositional change, which takes place in unmanaged primeval forests over decades and centuries, has prompted forest ecologists to split the continuous forest dynamics process into distinct stages (e.g. initial, optimal, and terminal stages; Leibundgut 1993; Korpel 1995; Meyer 1999), using forest structural attributes as criteria. Understanding the dynamics of primeval forests is a prerequisite for the full comprehension of the effects of forest management on production forests, where the natural age- and disturbance-driven dynamics are strongly reduced due to human intervention. How forest management affects the structure and functioning of forests, can be studied by comparing production forests of different management intensities, or alternatively by contrasting production forests with untouched primeval forests. The latter approach has the advantage that management activities are measured against a zero-use reference system, and managementrelated disturbance can be compared to natural disturbance regimes. Thus, management effects are assessed in relative terms. For capturing the role of natural disturbances in temperate forests, Roberts and Gilliam (1995a) suggested comparing the diversity patterns of different succession stages in managed forests to their equivalents in the natural successional sequence.

True primeval forests are extremely rare in the temperate forest biome, especially in Europe (Parviainen 2005) and eastern North America (Barbour \& Billings 2000). Comparing managed forests to abandoned former production forests several decades after abandonment is not necessarily an alternative, as the legacy of forest management may last for centuries (Freschet et al. 2013; von Oheimb et al. 2014). For example, past management could have extirpated species with low dispersal abilities in now abandoned production forests, which may lead to wrong conclusions on the effects of management on species richness. For this reason, comparative studies between untouched primeval and production forests are needed to understand, how human impact has influenced the structure and functioning of Europe's forests since centuries or even millennia (Kaplan et al. 2009) and how current and future management regimes might do.

In large parts of Central Europe, European beech (Fagus sylvatica L.) is the most important tree species of the natural forest vegetation in terms of dominance and abundance and it also represents a valuable timber species (Leuschner \& Ellenberg 2017). Only a few primeval forest remnants of beech have remained, mostly in the Carpathians and in Southeastern Europe. In 
these old-growth forests, a number of studies on the structure and dynamics have been conducted (e.g. Korpel 1995; Dusan et al. 2007; Kenderes et al. 2009; Trotsiuk et al. 2012), but systematic comparisons with adjacent beech production forests are very rare (e.g. Glatthorn et al. 2017a, b for wood biomass, leaf area index and aboveground productivity). Many more studies have compared production forests and unmanaged forests that have been affected by forestry in the past. A meta-analysis comparing unmanaged and differently managed forest stands at 120 locations in Europe's temperate and boreal forest biomes was conducted by Paillet et al. (2010), focusing on the diversity of different organism groups and different forest community types. One important result was that vascular plant species richness tended to be higher in managed forests due to management-related disturbances which favour the growth of shade-intolerant, highly competitive plants (Brunet et al. 1996; Schmidt 2005) and ruderal species such as Galium aparine, Glechoma hederacea or Deschampsia cespitosa (Decocq et al. 2004). Yet, the response to management was not uniform in the forests covered by this metaanalysis (Paillet et al. 2010). Other comparative studies from the temperate forest biomes of Europe (e.g. Boch et al. 2013; Brunet et al. 1996) and North America (Halpern \& Spies 2008; Scheller \& Mladenoff 2002) support this conclusion. A different picture emerged for epiphytic bryophyte and lichen species richness, which was found to be higher in unmanaged forests (Paillet et al. 2010) due to an increased number of specialist species (Hedenås \& Ericson 2003), which depend on the availability of suitable substrates like trees of high age (e.g. the lichens Lobaria pulmonaria and Thelopsis rubella) and a large amount of deadwood in different decay stages (e.g. the liverworts Cephalozia catenulata and Nowellia curvifolia) (Fritz et al. 2009a, b; Ódor et al. 2005, 2006). These species have been replaced in production forests by generalists common to other disturbed habitats (Nascimbene et al. 2007), e.g. the lichen species Lecanora expallens and Parmeliopsis ambigua, and the bryophytes Ptilidium pulcherrimum and Aulacomnium androgynum, which are characteristic for sites receiving higher nutrient and pollutant deposition than the forest interior (Friedel et al. 2006). This result is supported by several more recent case studies (e.g. Dymytrova et al. 2014; Odor et al. 2014), confirming the view that the richness of epiphytic bryophytes and lichens is more strongly affected by forest management-related disturbances than the diversity of the vascular ground layer vegetation (Aragón et al. 2010; Brunet et al. 2010; Hofmeister et al. 2015). A likely explanation is that epiphytic cryptogams depend much more on canopy structure, tree age and the amount of deadwood than the vascular ground vegetation does (Fritz et al. 2009b; Jonsson et al. 2005; Rose 1992). These factors control the species composition and diversity in addition to 
microclimatic and edaphic factors that are relevant for both ground-living species and epiphytes (Beatty 2014; Hauck 2011; Leuschner \& Lendzion 2009).

Studying the species diversity in five different development stages of a primeval Picea abies forest in Germany, Dittrich et al. (2013) found a higher bryophyte and lichen species richness in those parts of the forest that represented the overmature and decay stages. This was attributable to the preference of many epiphyte species for old and decaying trees which provide a higher diversity of microhabitats. The species richness minimum was, however, not found in the regeneration stage immediately after the breakdown of the senescent trees, since the deadwood legacy from the past tree generation allowed the survival of many bryophyte and lichen species across consecutive generations. Rather, the lowest species richness was found in the second (initial) stage, when most deadwood had been decomposed. In contrast, vascular plant species richness was not affected by the age dynamics in this spruce primeval forest (Dittrich et al. 2013). Similar information on diversity patterns in beech primeval forests is lacking.

We were interested in the detection of possible species diversity patterns in dependence on natural forest development as driven by tree ageing and natural disturbance events, and in the identification of vascular plant, bryophyte and lichen species characterising a certain forest development stage. Forest development processes are largely suppressed in production forests, where human intervention controls the age structure and stand density and strongly reduces the number of old trees beyond rotation age as well as the amount of deadwood. Since not only tree age and structural diversity influence species diversity and composition, but also habitat continuity (Dittrich et al. 2013; Rose 1992), we further raised the question, whether primeval forests harbour a higher total plant species, but lower vascular plant species richness than production forests across all development stages, or whether only the later development stages differ in their species richness from production forests.

In this study, we analyzed the species richness and composition of the vascular plant, bryophyte and lichen vegetation in three different forest development stages (initial, optimal and terminal stages) of three primeval beech forests in Slovakia and compared the results to three beech production forests. F. sylvatica forests are well suited to investigate questions related to diversity patterns, as only a single dominant tree species is present and European beech forests are the potential natural forest vegetation in large parts of Central Europe. The short distance between primeval and production forests $(<1 \mathrm{~km})$ guaranteed that the climatic and edaphic conditions were sufficiently comparable between the management types. As the primeval 
forest's initial and optimal stages are in terms of stand structure best comparable to a production forest immediately before harvest, we selected 70-100 year-old beech stands for comparison, allowing for a long period of low human impact, in which vascular plants and epiphytes had the opportunity to colonize. With reference to the profound structural changes occurring in the course of natural forest development, we hypothesized (1) that the ground and epiphyte vegetation and its composition significantly differs between the three beech forest development stages. Recalling that the presence of live and dead large-diameter trees is a prerequisite for cryptogamic epiphytes to establish, we further hypothesized (2) that tree diameter is positively correlated with the species richness of epiphytic bryophytes and lichens and that the epiphyte species composition differs significantly between large- and small-diameter trees. In consideration of the high structural diversity and long forest continuity of primeval forests, we finally hypothesized (3) that the species richness of epiphytic bryophytes and lichens, but also of the ground layer vegetation, is higher in any of the development stages of the primeval forest (including the initial stage) than in the production forests.

\subsection{Material and Methods}

\section{Study area}

The study was conducted in the western Carpathian Mountains in eastern Slovakia, centraleastern Europe. In the Slovakian and Ukrainian Carpathians, some remnant beech primeval forests have survived forest devastation and widespread conversion to production forests; they are now included in UNESCO's World Heritage List as the "Primeval beech forests of the Carpathians". We selected three primeval beech forest areas within a maximum distance of 45 km as study sites, namely Havešová, Stužica (in Poloniny National Park), and Kyjov (in the Vihorlat Protected Landscape Area, see Fig. 3.1). The Stužica forest ( $49^{\circ} 40$ N, $22^{\circ} 31$ E) covers 659 ha, the Havešová forest $\left(49^{\circ} 00 \mathrm{~N}, 22^{\circ} 20 \mathrm{E}\right) 171$ ha, and the Kyjov forest $\left(48^{\circ} 51 \mathrm{~N}, 22^{\circ} 10\right.$ E) 53 ha; detailed information on these conservation areas is given in Vološčuk (2014). According to Kucbel et al. (2012), there are no traces of direct human intervention in any of the three study sites. Regional management plans also specify these forests as being without any management for a long period before the enforcement of legal protection. The very low population density in this area (1-25 inhabitants $\mathrm{km}^{-2}$; Stock Map Agency 2007), the rough terrain, which made timber harvesting impossible without technical equipment not available in the past, and the fact that beech trees in these forests reach ages over 400 years (as shown by unpublished tree-ring analyses of our group), further ascertain that these forests can be 
considered as true primeval forests with no larger direct human intervention for the past several hundred years (Korpel 1995).

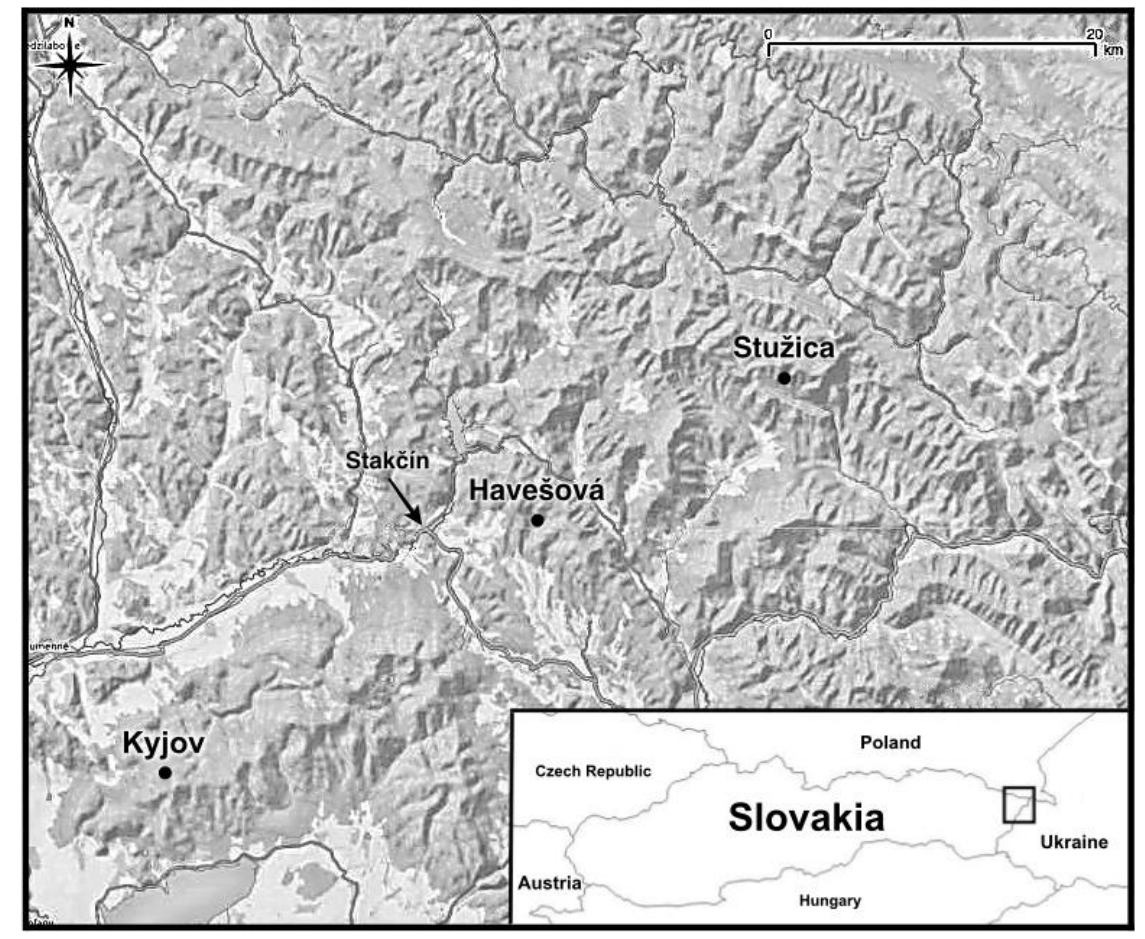

Figure 3.1. Location of the three study sites Kyjov, Havešová, and Stužica in the Carpathian Mountains of eastern Slovakia.

Within a distance of $1 \mathrm{~km}$ to the primeval forests, three beech production stands were selected in Havešová (size: 3.8 ha), Kyjov (8.3 ha) and Stužica (6.9 ha). The short distance guaranteed comparable edaphic and climatic conditions in the managed and unmanaged forests. The age of the production stands varied between 90-100 years (Havešová and Kyjov) or 70-100 years (Stužica). These beech forests are managed in a shelterwood cutting system with two cuts conducted within 10 years at the end of the production cycle, while no or only scarce management activities are conducted during the first 80-90 years. This type of forest management is widely used in Slovakian beech production forests and practiced in strips parallel to the slope, structuring the production forests in elongated sections of beech cohorts of similar age and relatively high stem density (Marušák 2007). Most of the Slovakian beech production forests are managed with rotation periods of typically 80-100 years with the consequence that more than $90 \%$ of the beech forest area is younger than 100 years (National Forest Centre 2009). We selected production forests close to the rotation age for our study, since these forests, which existed without management intervention for 70-100 years, were expected to show the highest similarity to the primeval forest. 
All six studied forest stands ( 3 primeval and 3 production forests) were located at sub-montane to montane elevation (500-950 $\mathrm{m}$ a.s.1., Table 3.1), while the sites were differing somewhat in elevation and thus in mean annual precipitation and temperature. Due to differences in bedrock (andesite vs. flysh), the soils in Kyjov (Dystric Cambisols) were nutrient-poorer than those in Havešová and Stužica (Eutric Cambisols; Vološčuk 2014). The forests in Kyjov grew predominantly on north-facing slopes, while south-facing slopes dominated in Havešová and Stužica.

The recent synsystematic survey of Slezak et al. (2016) listed several acidophytic beech forest associations for Slovakia, but our relevés of the ground vegetation of the study sites did not allow assigning our assemblages to any of the listed associations in the alliances Luzulo-Fagion sylvaticae and Fagion sylvaticae. Most relevés could best be assigned to the western Carpathian association Dentario glandulosae-Fagetum after Neuhäusl et al. (1982). In all six stands, Fagus sylvatica was strongly dominant in the tree layer. In the primeval forests of Havešová and Kyjov, a few individuals of other tree species, notably Acer platanoides and Fraxinus excelsior, were admixed. In Stužica, beech was locally associated with greater proportions of Abies alba, which locally even dominated the shrub layer. However, the proportion of other tree species was higher in the production forests than the primeval forests in Havešová (39 \%), Kyjov (6 \%) and Stužica (23\%). Yet, beech was still the dominant tree species in these managed stands.

Table 3.1. Physiographic characteristics of the three primeval forest sites in eastern Slovakia. The conditions in the nearby production forests (distance $<1 \mathrm{~km}$ ) are very similar. ${ }^{\mathrm{a}}$

\begin{tabular}{lccc} 
& Havešová & Kyjov & Stužica \\
\hline Elevation (m a.s.l.) & $550-650$ & $700-820$ & $700-950$ \\
Mean annual precipitation $\left(\mathrm{mm} \mathrm{yr}^{-1}\right)$ & $800-850$ & $950-1000$ & $900-1200$ \\
Mean annual temperature $\left({ }^{\circ} \mathrm{C}\right)$ & $6.0-6.5$ & $5.2-5.7$ & $4.0-5.0$ \\
Geology & Carpathian Flysh & Andesite & Carpathian Flysh \\
Soil type & Eutric Cambisol & Dystric Cambisol & Eutric Cambisol \\
Aspect & $\mathrm{S}-\mathrm{SW}$ & $\mathrm{N}-\mathrm{NE}$ & $\mathrm{S}$ \\
LAI $\left(\mathrm{m}^{2} \mathrm{~m}^{-2}\right)$ & $9.7 \pm 2.5$ & $7.7 \pm 2.4$ & $8.1 \pm 2.2$ \\
\hline
\end{tabular}

Data after Korpel (1995), except for LAI (Glatthorn et al. 2017a).

\section{Study design}

In order to analyse changes in species composition and richness throughout the development of natural beech forests with initial, optimal and terminal stage, 40 circular plots of $500 \mathrm{~m}^{2}$ size were established in each primeval forest in systematic grids that had a mesh size of $140 \mathrm{~m}$ 
(Havešová), $100 \mathrm{~m}$ (Stužica) and $64 \mathrm{~m}$ (Kyjov) as the minimum distance between neighbouring plot centres. The variable distances were chosen to ensure that 40 research plots could be established within each primeval forest at a minimum distance to the reserve borders of $100 \mathrm{~m}$. After plot selection and inventory of stand structural properties, all plots were assigned to one of the three development stages based on the frequency of stem diameter classes occurring in the plot. Three diameter-at-breast-height classes (dbh) were distinguished according to a categorisation of tree dimensions widely used in silviculture (Röhrig et al., 2006): 7-39 cm (premature trees), 40-69 $\mathrm{cm}$ (mature trees of harvestable size) and $\geq 70 \mathrm{~cm}$ (large trees usually absent from production forests). These dbh classes were used to assign the plots to the initial (dominance of premature trees), optimal (dominance of mature trees) or terminal stage (dominance of large old trees). Since the $500 \mathrm{~m}^{2}$ plots usually harboured trees of more than one dbh class and, thus, by our definition, represented more than one development stage, we quantified the relative abundance of the three dbh classes for every plot and then assigned the plot to the dominant, i.e. most abundant, development stage. The relative dominance of a given dbh class (index dom $\mathrm{DSi}$, with indication of the development stage) was quantified by averaging over two measures of stand density for the trees in the respective diameter class: stem density $\left(\operatorname{tn}_{\mathrm{DSi}}\right.$ in $\left.\mathrm{n} \mathrm{ha}^{-1}\right)$ and stem volume $\left(\operatorname{vol}_{\mathrm{DSi}}\right.$ in $\left.\mathrm{m}^{3}\right)$. The volume of living trees was calculated according to Petráš and Pajtík (1991); for dead trees, we applied a reduction factor in dependence on their decay class (Meyer et al. 2001). In order to avoid assumptions about the actual distribution of tree numbers and tree volumes per hectare, we refrained from parameterizing a distribution function, but used instead the empirical $85 \%$ sample-quantile as reference value for plots with relative dominance of a development stage. This approach was found to represent a robust measure of the dominance of trees of a given diameter class in a plot. The index value was obtained from the equation given in Glatthorn et al. (2017a) as

$$
\begin{gathered}
d o m_{D S i}=\frac{1}{2}\left(\frac{\text { vol }_{D S i}}{\operatorname{vol}_{D S 0.85}}+\frac{t n_{D S i}}{t n_{D S 0.85}}\right) \text { for all plots } i \text { with } i \\
\in\{1,2, \ldots, n\}
\end{gathered}
$$

This index was calculated for every dbh class per plot and the plot was assigned to the dbh class with the highest index value. This procedure has been developed by Feldmann et al. (2018) and Glatthorn et al. (2017a) in the studied forests. The potential maximum tree numbers and basal areas were taken from the study plots with the highest dominance of trees of a dbh of 7-39 cm, $40-69 \mathrm{~cm}$, and $\geq 70 \mathrm{~cm}$, respectively. According to our index calculations, $\sim 37 \%$ of the 120 
plots of the three primeval forests belonged to the initial stage, $\sim 29 \%$ to the optimum stage, and $\sim 34 \%$ to the terminal stage (Table A3.1).

In the three production forests, which had a much smaller size than the primeval forests, each ten plots of $500 \mathrm{~m}^{2}$ size were studied with identical methods. However, a distance of only $50 \mathrm{~m}$ between the individual plots could be realized here (Kaufmann et al. 2017). The three production forests corresponded in their structure best to the optimal stage in the primeval forests (Table A3.1).

\section{Stand properties}

The diameter at breast height $(1.3 \mathrm{~m})$ was recorded for all trees with $\geq 7 \mathrm{~cm}$ dbh in the plots. Table A3.2 summarizes these results for the six stands and the three development stages of the primeval forests. Of the eight analysed stand-structural parameters, no other parameters than stem density and mean dbh of live trees (which were used to separate between the forest development stages) differed significantly between the three stages. The dbh of living trees was highest in the terminal stage and differed significantly from the initial and optimal stages in Havešová, whereas no significant differences were found for Kyjov and Stužica. Stem density was generally lower in the terminal stage.

The analysed stand properties of each development stage (pooled over the three study sites) were also contrasted with the production forests, which represented a final stage shortly before harvest (Table A3.3). As a consequence of management, stem density as well as the mean diameter of live and dead standing trees and downed deadwood differed significantly between the production forests and the three development stages of the primeval forests.

\section{Vegetation analysis}

Vegetation sampling was done mainly in the growing season 2014 and supplemented by records from fall 2013 and spring 2015. With respect to the ground vegetation, the cover of all vascular plants and terricolous bryophytes and lichens was estimated in the $500 \mathrm{~m}^{2}$ plots. For woody plants, cover was estimated separately for the herb $(<0.5 \mathrm{~m}$ height $)$, shrub $(<2 \mathrm{~m})$, and tree layers $(>2 \mathrm{~m})$. Terricolous bryophytes and lichens were noted in a separate cryptogam layer. The cover of all species was estimated using $5 \%$-classes for species covering $\geq 10 \%$ of the total plot area. For species covering less than $10 \%, 1 \%$-classes were used; $0.1 \%$ (one individual) and $0.5 \%$ (more than one individual) categories were assigned to species occurring on $<1 \%$ of the plot area (Dittrich et al. 2013). Epiphyte species were recorded at 0 to $2 \mathrm{~m}$ height 
on the trunks of all living and dead standing trees with diameter $\geq 15 \mathrm{~cm}$ in the $500 \mathrm{~m}^{2}$ plots. Trees with smaller dbh were not studied, as epiphyte cover was generaly very low on these trees. The cover of bryophytes and lichens on living and dead standing trees was estimated using the same percent classes as applied for the ground vegetation. Presence/absence data were recorded for bryophytes and lichens from the whole upper surface and the flanks of downed deadwood.

Herbarium specimens were collected, if species could not be identified in the field. For the identification of the bryophytes and lichens, light microscopy was used. Further, thin layerchromatography (TLC) was performed according to Orange et al. (2001), where the qualitative analysis of secondary lichen metabolites was appropriate for species identification. The TLC results were evaluated by using the LIAS Metabolites Data Base (Elix et al. 2012). Nomenclature follows Danihelka et al. (2012) for vascular plants, Hodgetts (2015) for bryophytes, and Guttová et al. (2013) for lichens. The complete species list of species in the primeval and production forests is compiled in Table A3.4.

\section{Statistical analyses}

Unless stated otherwise, we used R software (version 1.1.383) for all statistical analyses. Arithmetic means \pm standard errors were calculated to explore stand structural differences between the three forest development stages in the three study sites and between the primeval and production forests, as well as for characterising the mean plot-level species richness of vascular plants, bryophytes and lichens. The data were tested for normal distribution with the Shapiro-Wilk test. The Kruskal-Wallis test for non-normally distributed data was applied to test for significant differences of means in the data set. Multiple comparisons were conducted with Dunn`s test, if the Kruskal-Wallis test indicated significant differences.

For detecting differences in total species richness between the three forest development stages, sample-based rarefaction/extrapolation curves based on the species' frequency of presence with 95\% confidence intervals were computed using the R package "iNEXT" (Hsieh et al. 2015). This approach allows comparing the species richness ( $\alpha$-diversity) of unequal sample sizes with reliable statistical inference (Chao et al. 2014). However, extrapolation is feasible only up to a doubling of the recorded reference sample size (Colwell et al. 2012), which is in our case twice the number of sampling units of each forest development stage or each production forest. Beyond this threshold, the results may be biased (Chao et al. 2014). If the 95\% confidence intervals do not overlap, species numbers differ significantly at $P \leq 0.05$ (Colwell et al. 2012). 
Preferences of individual vascular plant, bryophyte and lichen species for the three forest development stages were revealed by conducting canonical correspondence analysis (CCA) with the R package "Vegan 2.4-3" (Oksanen et al. 2016). In this analysis, the calculated relative dominance index of a forest development stage (domDSi; see chapter 2.2.) in a sampling unit was used as the continuous independent variable. Further, a permutation test ( $\mathrm{N}=999)$ was performed to assess the significance of the ordination axes. The CCA was computed by using absolute frequencies (bryophytes and lichens) or cover percentages (ground vegetation), respectively.

In order to detect significant associations of epiphytic bryophyte and lichen species with different stem diameter classes in the primeval forests, we employed Indicator Species Analysis (ISA) using PC-Ord 5.14 (Dufrene \& Legendre 1997). With the exception of deadwood epiphytes, where presence/absence data were used, ISA was calculated with cover percentages. The effects of stem diameter on the species richness of bryophytes and lichens in the primeval forests were analysed with generalized linear models (GLM) with a log-link function and a negative binomial error using the R package "MASS 7.3-47” (Venables \& Ripley 2002).

Rarefaction/extrapolation curves were also employed for analysing differences in species richness between the three development stages of the primeval forests and the production stands. Stem diameter effects on the richness of epiphytic bryophytes and lichens in the production forests were analysed with GLMs as described for the primeval forests.

\subsection{Results}

Species richness and species composition in different primeval forest development stages

The mean plot-level species richness of vascular plants in the ground vegetation $\left(500 \mathrm{~m}^{2}\right.$ plots $)$ did not differ between the three development stages (Table 3.2). The mean species richness of bryophytes and lichens in the study plots on the trunk bases (0-2 $\mathrm{m})$ on live trees and standing deadwood increased significantly from the initial to the terminal stage (Table 3.2). On downed deadwood, in contrast, mean bryophyte and lichen species richness did not differ between the three forest development stages (Table 3.2).

As indicated by overlapping confidence intervals of the rarefaction/extrapolation curves, the species richness of vascular plants (Fig. 3.2c) and bryophytes (Fig. 3.2a) did not differ between the initial, optimal, and terminal stages of the primeval forests, when analysing 70 plots, i.e. twice the minimum sample size ( $N=35$ plots in the optimal stage). The number of lichen species, 
however, tended to be higher in the terminal $(P \leq 0.05)$ and optimal $(P \leq 0.10)$ stages than in the initial stage (Fig. 3.2b). In the case of vascular plants and lichens, the extrapolated species richness in the terminal stage (vascular plants and lichens; Figs. 3.2c, 3.2b) and optimal stage (lichens; Fig. 3.2b) increased with the number of plots even far beyond the reference sample size. In contrast, the extrapolated richness curves for bryophytes saturated already at a sample size of 70 plots.

Table 3.2. Mean plot-level species richness ( \pm standard error) of vascular plants on the ground, and epiphytic bryophytes and lichens on live trees and standing or downed deadwood in the initial, optimal, and terminal stages of the three primeval forests.

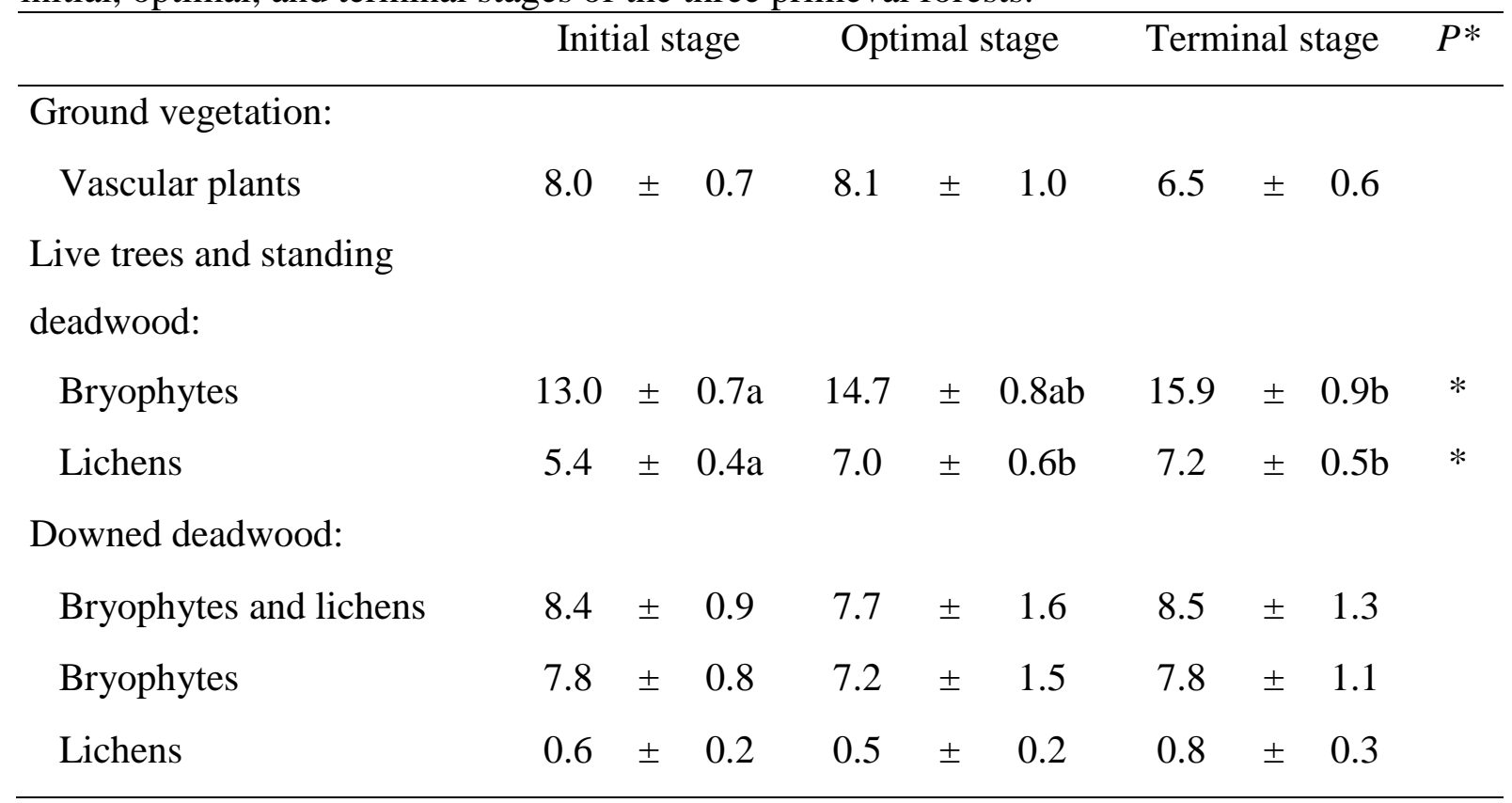

Statistical analyses: * $\mathrm{P} \leq 0.05, * * \mathrm{P} \leq 0.01, * * * \mathrm{P} \leq 0.001$ (Kruskal-Wallis test), additional testing with Dunn`s test for multiple comparisons. Within a row, mean values followed by equal letters do not differ significantly. Number of samples: ground vegetation: $N=120$ plots sampled; epiphytes: $N=1135$ trees (live trees and standing deadwood) and 158 downed dead logs sampled.

CCA ordination of the forest floor vascular plants and bryophytes showed that the majority of species was not associated with a forest development stage (Fig. A3.5), indicating a more or less continous occurrence of most species across the stages in the primeval forests. The MonteCarlo test result was only significant $(P \leq 0.05)$ for the first axis of the CCA, allowing to separate species characteristic for the initial stage from taxa characterising the optimum and terminal stages. Table 3.3 lists forest floor species with distinct preferences for one of the three forest development stages. Species associated with the initial stage included Chelidonium majus, Senecio ovatus, and Urtica dioica. Species apparently preferring the two other stages included Lunaria rediviva, Oxalis acetosella, and Polygonatum verticillatum (all with a trend for 
preference of the optimum stage), as well as Stachys sylvatica and the moss Brachythecium rutabulum (most strongly associated with the terminal stage).

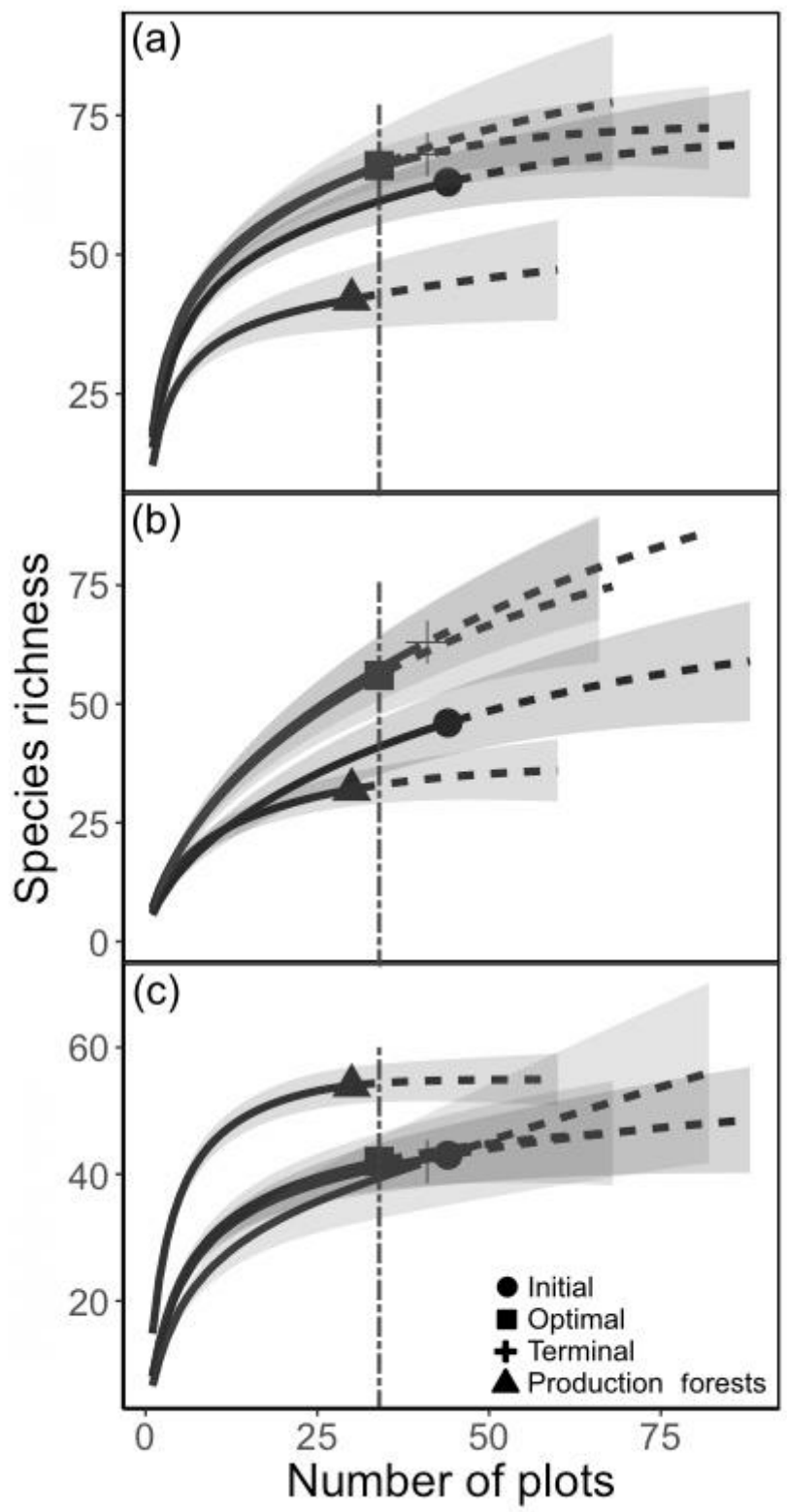

Figure 3.2. Rarefaction (solid line)/extrapolation (dashed line) curves for the richness of epiphytic bryophytes (a) and lichens (b), and herb layer vascular plants (c) occurring in plots assigned to the initial $(N=44)$, optimal $(N=35)$ or terminal stages $(N=41)$ of the primeval forests, and the corresponding production forests $(N=30)$. The vertical dot-dashed line represents the reference sample size $(N=35)$. Confidence intervals are shaded. Pooled data from the three primeval and production forests.

In contrast to the vascular plants, the CCA showed clear development stage preferences of epiphytic bryophytes and lichens on living trees as well as standing and downed deadwood (Fig. A3.2). Table 3.3 lists epiphytic bryophyte and lichen species with distinct preferences for one of the three forest development stages according to the CCA. Most bryophytes in the primeval forests (Monte Carlo test significant for axes 1 and 2) preferred either the optimum 
(e.g. Amblystegium varium, Herzogiella seligeri, Orthotrichum pallens) or the terminal stage (Anomodon longifolius, Anomodon rugelii, Zygodon rupestris). Typical bryophyte species of the initial stage included Brachythecium reflexum, Homalothecium sericeum, and Hypnum pallescens.

Table 3.3. Individual species preferences of the three forest development stages (initial, optimal and terminal stage) revealed by conducting canonical correspondence analysis (CCA) ordination for the forest floor vegetation (Fig. A3.1) and epiphytic bryophytes and lichens (Fig. A3.2).

\begin{tabular}{llll}
\hline Species & Initial & Optimal & Terminal \\
\hline Ground & Chelidonium majus, & Lunaria rediviva, Oxalis & Stachys sylvatica, \\
vegetation & Senecio ovatus, Urtica & acetosella, Polygonatum & Brachythecium \\
& dioica & verticillatum & rutabulum (M) \\
Bryophytes & Brachythecium reflexum, & Amblystegium varium, & Anomodon \\
& Homalothecium & Herzogiella seligeri, & longifolius, \\
& sericeum, Hypnum & Orthotrichum pallens & Anomodon rugelii, \\
& pallescens & & Zygodon rupestris \\
& & & \\
Lichens & Graphis scripta, Lecania & Ochrolechia subviridis, & Belonia herculina, \\
& cyrtella, Micarea & Chaenothecopsis pusiola & Chaenotheca \\
& peliocarpa, Pertusaria & (nl), Mycocalicium & brunneola, \\
& pustulata, Porina aenea & subtile (nl) & Dictyocatenulata alba \\
\hline
\end{tabular}

(M) and (nl) represent forest floor moss species and non-lichenized fungi, respectively.

For lichen species more advanced stages also seem to harbour a particularly high species richness (Fig. A3.2c, d). The CCA results for lichens on live trees and deadwood should be interpreted more carefully, since the Monte Carlo test yielded a positive result for the first axis only, primarily allowing for a separation of species associated with the initial stage (e.g. Graphis scripta, Lecania cyrtella, Micarea peliocarpa, Pertusaria pustulata, Porina aenea) from species prefering the terminal stages (Belonia herculina, Chaenotheca brunneola, Dictyocatenulata alba). Species with a trend for preference of the optimum stage included Ochrolechia subviridis and the non-lichenized fungi Chaenothecopsis pusiola and Mycocalicium subtile. 
Effects of stem diameter on epiphyte species richness and composition in the primeval forests

Stem diameter exerted a strong effect on bryophyte species richness, while the effect was weaker for lichen species richness (Fig. 3.3a). In the primeval forests, lichens showed the

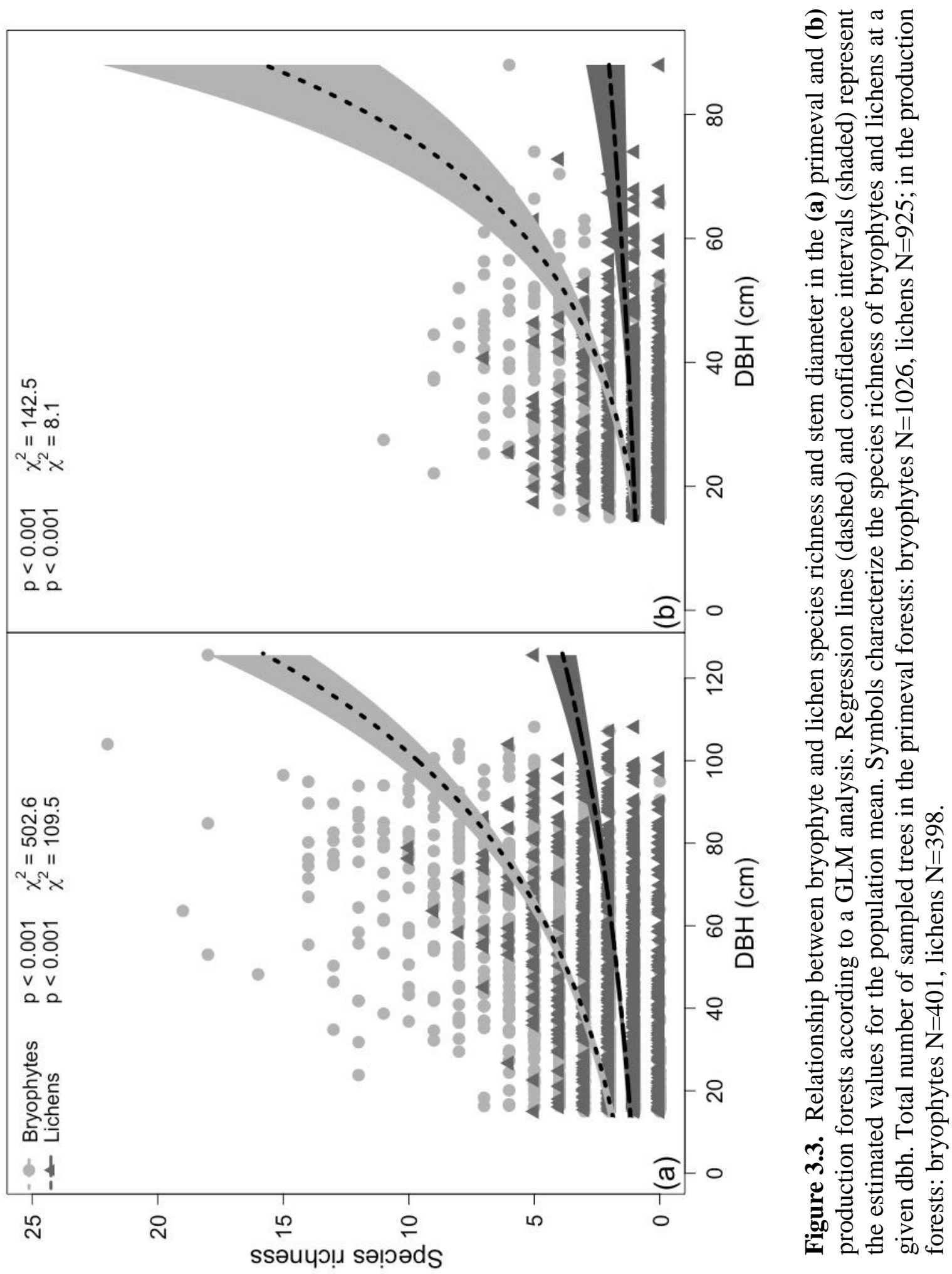


highest species numbers on intermediate stem diameters $(40-69 \mathrm{~cm}$; with two exceptions), whereas the bryophyte species richness peaked on trees $>70 \mathrm{~cm}$.

Table 3.4. Results of an Indicator Species Analysis for epiphytic bryophytes and lichens on standing (live and dead, $N=1135)$ and downed trees $(N=158)$ of different diameter classes; only species with significant results are shown.

Stem dia- $\quad$ Species with $P$ value (in brackets)

meter

class $(\mathrm{cm})$

Living trees and standing deadwood:

$<40 \quad$ Bryophytes: -

Lichens: Graphis scripta (0.002), Porina aenea (0.02)

40-69 Bryophytes: Hypnum pallescens (0.01)

Lichens:

$\geq 70$ Bryophytes: Amblystegium serpens, Anomodon attenuatus, Anomodon rugelii, Hypnum cupressiforme, Hypnum cupressiforme var. filiforme, Isothecium alopecuroides, Leucodon sciuroides, Metzgeria conjugata, Metzgeria furcata, Neckera besseri, Paraleucobryum longifolium, Plagiothecium curvifolium, Plagiothecium laetum, Platygyrium repens, Porella platyphylla, Pseudoleskeella nervosa, Pterigynandrum filiforme, Radula complanata, Scirohypnum populeum (all 0.002), Brachythecium salebrosum (0.004), Brachythecium rutabulum (0.006), Amblystegium subtile (0.008), Brachytheciastrum velutinum, Plagiothecium succulentum (all 0.01), Dicranum montanum, Ptilidium pulcherrimum (all 0.02), Anomodon viticulosus (0.03), Orthotrichum stramineum, Plagiomnium cuspitatum (all 0.04)

Lichens: Coenogonium pineti, Lepraria incana (all 0.002), Belonia herculina, Candellariella xanthostigma, Chaenotheca xyloxena (all 0.004), Alyxoria varia, Cladonia coniocraea, Evernia prunastri (all 0.01), Cladonia digitata, Lecanora glabrata (all 0.02), Parmelia sulcata, Phlyctis argena, Thelotrema lepadinum (all 0.03), Amandinea punctata (0.04)

Downed deadwood:

$<40 \quad$ Bryophytes: -

Lichens: -

40-69 Bryophytes: Hypnum pallescens (0.006), Sciro-Hypnum populeum (0.05)

Lichens: -

$\geq 70$ Bryophytes: Dicranum viride (0.002), Isothecium allopecuroides (0.01), Lophocolea bidentata, Paraleucobryum longifolium (all 0.02), Campylium sommerfeltii (0.03), Orthotrichum obtusifolium (0.04)

Lichens: - 
Species Indicator analysis showed that most species were significantly associated with largediameter trees of $\geq 70 \mathrm{~cm}$ dbh (Table 3.4). Further, $50 \%$ of the 70 recorded bryophyte species on live trees and standing deadwood were indicator species of large-diameter trees with a dbh $\geq 70 \mathrm{~cm}$. In contrast, only $22 \%$ of the 79 recorded lichen species were indicators of trees with a dbh $\geq 70 \mathrm{~cm}$. Typical epiphytes of large-diameter trees included the bryophytes Amblystegium subtile, Anomodon rugelii, Metzgeria furcata and the lichens Belonia herculina, Chaenotheca xyloxena and Lecanora glabrata. Only one moss was characteristic for trees with a dbh of 40$69 \mathrm{~cm}$, i.e. Hypnum pallescens. In contrast, two lichen species were identified as indicators of low-diameter trees (dbh $<40 \mathrm{~cm})$, i.e. Graphis scripta and Porina aenea.

For downed deadwood, we detected the highest number of indicator species for large-diameters $\geq 70 \mathrm{~cm}$ (six bryophytes, but no lichen, of a total of 48 and 17 species, respectively), e.g. Dicranum viride, Isothecium alopecuroides and Lophocolea heterophylla. For deadwood of smaller diameter $(40-69 \mathrm{~cm})$, two indicative bryophyte species were detected (Hypnum pallescens and Sciro-Hypnum populeum), but no epiphyte species was found with a significant preference for very low stem diameters $(<40 \mathrm{~cm})$.

\section{Species richness in primeval and production forests}

Compared to the production forests, the cumulative species richness of the ground vegetation (vascular plants) was significantly lower in any development stage than in the production forest plots (Fig. 3.2c), when $<30$ plots were sampled. However, the rarefaction/extrapolation curves suggest that vascular plant species richness does saturate in the production forests already at 30 plots, whereas the curves for the three forest development stages of the primeval forest continue to increase even far beyond a sample size of 70 plots, i.e. twice the reference sample size. In all three development stages of the primeval forests, cumulative bryophyte and lichen species richness on live and dead standing trees and downed deadwood was significantly higher than in the production forests at a sample size of 60 , i.e. twice the number of plots of the production stands (Fig. 3.2a, b). Counted in a sample of 30 plots, total epiphyte species numbers in the three primeval forest development stages exceeded the corresponding species richness of the production forests by ca. $50 \%$ (with exception of the lichen species number of the intial stage). Even the initial stage of the primeval forests harboured a distinctly higher epiphyte diversity than the production forests close to harvest ( $P \leq 0.10$ for lichens).

As in the primeval forests, stem diameter strongly influenced epiphyte species richness in the production forests (Fig. 3.3b). The highest bryophyte species richness was observed in intermediate stem diameter classes (40-69 cm, with one exception), which may be caused by 
the virtual absence of trees with stem diameters $>70$ in the production forests. In contrast, lichens reached highest species numbers in the dbh-classes $<40 \mathrm{~cm}$. Across the full stem diameter range, epiphytic bryophytes and lichens were more species-rich in the primeval as compared to the production forests in a given dbh class (Fig. 3.3a, b).

\subsection{Discussion}

\section{Response of ground vegetation and epiphytes to natural forest development}

In contradiction to our first hypothesis, neither the species richness of the ground vegetation nor its composition showed a strong influence of the forest development stage. Most species occurred across all three development stages and did not disappear in a certain stage; they thus may persist over long time spans in the primeval forest. A similar continuity of species richness and species composition was observed by Gilliam et al. (1995) in each two young and mature central Appalachian hardwood forests. Our result also agrees with observations from a primeval Picea abies forest in Central Germany, where the lacking herb layer response to forest development was attributed to the typically small gap size in this natural coniferous forest (Dittrich et al., 2013). It appears that small gaps resulting from the death of single trees in the course of natural forest development have not much impact on the species richness and composition of the ground vegetation.

When gaps are larger, the dependence of herb layer composition on forest development processes becomes greater. Gaps increased the species richness of the ground vegetation in managed Fagus sylvatica forests (Naaf \& Wulf 2007; Kelemen et al. 2012), which can be explained in agreement with the intermediate disturbance hypothesis of Connell (1978) by the addition of light-demanding species to the species pool of shade-tolerant vascular herb layer species. The cover and species composition of the overstory affects the light regime, but may also influence the availability of nutrients and water to herbaceous layer plants (Leuschner \& Ellenberg 2017; Gilliam \& Roberts 2014). Although the identity of species found in the CCA to be associated with initial stages (e.g. Chelidonium majus, Urtica dioica) suggests higher light and nutrient availability as a consequence of gap formation, this effect is probably much smaller in $F$. sylvatica forests than in other European temperate forest ecosystems. The most frequently observed gap size in the Slovakian F. sylvatica primeval forests was less than $100 \mathrm{~m}^{2}$, which seems to be formed more or less continuously over time. In addition, gap formation might be of lower significance for the ground vegetation in multilayered beech primeval stands than in other temperate natural forests, because beech is capable of rapidly closing gaps by vital lateral 
crown expansion. This explains why optical LAI measurements with the Plant Canopy Analyzer by Glatthorn et al. (2017a) did not show significant leaf area differences between the three forest development stages in our plots. These results suggest that light-driven increases in species richness, as repeatedly reported from production forests (Kelemen et al. 2012; Naaf \& Wulf 2007), seem not to be the rule in primeval beech (and spruce) forests, where such responses may largely be restricted to windthrow and other rare catastrophic large-scale disturbances (Degen et al. 2010). These events can create gaps $>500 \mathrm{~m}^{2}$, as was observed in the Havešová forest in our study.

Much more sensitive to forest development processes is the epiphyte vegetation. The species richness of epiphytic bryophytes and lichens on live trees and standing deadwood increased from the initial via the optimal to the terminal stage, thus providing support for our first hypothesis in this point. This response of epiphytic bryophytes and lichens meets the expectation, since epiphytes do not only respond to light regime changes in the course of the forest development, but strongly depend on tree age and tree size as well as on the presence of deadwood (Ódor \& van Hees 2004; Pach \& Podlaski 2015). The latter factors are closely related to the ageing of trees and senescence. Many epiphytic bryophytes and lichens prefer old largediameter trees and deadwood of large diameters with specific hydrological and chemical properties (Ódor \& van Hees 2004; Hauck 2011; Pach \& Podlaski 2015). This explains the increase in species richness of epiphytic bryophytes and lichens on live trees and standing deadwood towards the terminal stage that was also observed by Dittrich et al. (2013) in a primeval Picea abies forest. In contrast, only few specialists of smooth bark characteristic for young trees (e.g. Graphis scripta, Porina aenea) do exist in European beech primeval forests. The plot-level species richness of bryophytes and lichens on downed deadwood did not differ between the three forest development stages in Slovakia, again contradicting our first hypothesis. Other than in case of the low variability of ground layer species richness, this is not attributable to low variation in light conditions, but likely caused by the presence of downed deadwood in plots of all development stages. Surveys of deadwood stocks showed no significant difference between the initial, optimal and terminal stages (Glatthorn et al. 2017b). The continuous presence of considerable amounts of downed deadwood in the plots is mainly the result of the high small-scale spatial heterogeneity of the primeval beech forests. The patches of a given forest development stage were in many cases of such small size that tree fall in a patch of senescent trees often influenced neighboring patches of the initial and optimum stages as well, creating a substantial deadwood stock even in the initial and optimal stages where normally no large-diameter deadwood is generated. 


\section{Effects of stem diameter on epiphyte diversity in the primeval forests}

As big trees are characterized by a larger heterogeneity of microsites on the stem (Friedel et al. 2006) with varying microclimatic and chemical conditions (Friedel et al. 2006; Fritz et al. epiphyte species richness generally increases with stem diameter and tree age (Johansson et al. 2007; Hauck 2011; Hofmeister et al. 2016). In support of our second hypothesis, epiphyte species richness on live trees and standing deadwood increased with increasing stem diameter. Furthermore, species composition changed with stem diameter, with only few species apparently preferring thin trees (two lichens with significant preference for trees $<40 \mathrm{~cm}$ ), but many species being specialists of large-diameter trees, which is demonstrated by the Indicator species Analysis. More than many lichens, epiphytic bryophytes depend on structured bark, which might be the key factor causing this strong preference of large-diameter beech trees, as with increasing age and stem diameter, beech bark becomes thicker and strongly fissured. Bryophytes also tend to be more moisture-dependent than many lichens and might thus benefit from the better water supply in bark fissures (Wiklund et al. 2004).

\section{Comparing the diversity of primeval forest development stages and production} forests

While epiphytic bryophyte and lichen species richness was markedly higher in the primeval than production forests, for vascular plants this was only true when large plot numbers, i.e. large forest areas, were investigated. The forest development stage was not decisive in the comparison of primeval and production forest. This means that even the initial stage of the primeval forests was richer in epiphytic bryophyte and lichen species, and at large sample sizes, also richer in vascular plant species than the production forests.

Many of the disturbance indicators of the vascular plants occur also in unmanaged forests, when the forest area is large and contains a variety of naturally disturbed habitats. The continued increase of vascular plant species richness at high plot numbers in the primeval forests is a consequence of the high stand and habitat diversity, leading to a high $\beta$-diversity in these stands (Kaufmann et al. 2017). Reports of a higher vascular plant species richness in production than primeval forests at small sample sizes base mostly on the dominance of management-related over natural disturbance events, which create habitats for disturbance-tolerant plants. In this case, the proportion of early-successional and also alien plants tends to increase, while primary forest species often decrease, as observed in a conifer forest of the Sierra Nevada in western North America (Battles et al. 2001), in Japanese beech forests managed as shelterwoods (Nagaike et al. 1999), and in clear-cut aspen forests in Michigan (Roberts \& Gilliam 1995b). 
Yet, the spread of grasses, sedges and other rapidly expanding species with management-related disturbances can also lead to a decrease in post-disturbance plant diversity (Abrams \& Dickman 1982).

The higher species richness in all stages of the primeval forests suggests that habitat continuity is a major determinant of the high plant species diversity in primeval forests. Most forms of timber harvest in production forests create larger gaps than those observed in the primeval forests. However, the effects of forest harvesting depend on several factors, e.g. the type of harvesting system, the equipment used, season of year, site conditions and others (Roberts \& Gilliam 2014). In Slovakian beech forests, stripwise clearcut is a widespread technique. In contrast, primeval forests of European beech contain larger gaps only, when rare large-scale disturbance events such as windthrow occur, which influence environmental conditions for both, the forest floor and epiphyte vegetation. Clearcuts disrupt the habitat continuity between successive forest generations and lead to strong changes in the light, temperature and air humidity regimes, and in soil conditions. Furthermore, the deadwood legacy, which bridges consecutive forest generations at least for bryophytes and lichens, is mostly lacking in production forests, where trees rarely achieve the age of senescence. Convincing evidence in support of the outstanding role of habitat continuity is provided by the comparison between primeval and production forests in terms of the epiphyte species richness at a given stem diameter. Trees occurring in the primeval forests harboured higher numbers of epiphytic bryophytes and lichens than stems in the production forests of comparable stem diameter. We assume that this is due to the fact that trees in the production forests rarely exceed 100 years, while maximum detected age was over 400 years in the primeval forests (R. Coventry, unpublished). Thus, the effect of higher structural heterogeneity on diversity is enhanced by greater habitat continuity. Since bryophytes and lichens on tree stems and deadwood benefit more directly from trees of high age and the occurrence of large-diameter deadwood than the ground vegetation, it is plausible that bryophytes and lichens respond much more sensitively to forest management than the bulk of vascular plants in the herb layer. This finding is in accordance with results from other studies in temperate forests (Aragón et al. 2010; Hofmeister et al. 2015; Dittrich et al. 2013).

Dispersal limitation represents a key factor underlying the habitat continuity effect on species distribution (Hilmo \& Såstad 2001; Hilmo 2002). In this context, it should be noted that most likely not only the production forests, but also the studied primeval forest remnants in the Carpathians have experienced species losses in the past, because these forests are isolated stands of limited size embedded in a large area of production forests. This implies that the 
observed difference in species diversity between primeval and production forests has probably been reduced over time due to ongoing diversity losses from the primeval forests.

\section{Conclusion}

This comparison of nearby primeval and production forests clearly shows a higher species richness in primeval than production forests for epiphytic bryophytes and lichens and, when plot numbers are sufficiently high, also for the vascular plants of the ground layer. Our results further highlight the extraordinary importance of stems with large diameters and the occurrence of high amounts of deadwood for the diversity of cryptogamic epiphytes. The absence of largesized senescent trees in beech production forests and the lacking continuity of suitable microhabitats due to timber harvest reduce overall plant species richness (cryptogams plus phanerogams) by about a third to a half compared to primeval forests, supporting our third hypothesis. Claims in the literature that forest management might increase plant diversity at least in the herbaceous layer compared to unmanaged forests, are not supported by this direct comparison with primeval forests. Unmanaged Central European beech forests are characterised by high structural heterogeneity and the prevalence of small-sized gaps caused by the death of single tree individuals; gap closure is occurring rapidly. The resulting small-scale patch structure of the forest is the main reason for the unexpected finding that the species richness and composition of the epiphytic and herb layer vegetation shows only moderate to minor variation between $500 \mathrm{~m}^{2}$-plots of the initial, optimal and terminal development stages. The astonishing similarity in vegetation composition of early and late stages suggests that forest continuity plays an even greater role for epiphyte diversity in natural forests of $F$. sylvatica than in old-growth stands dominated by other temperate tree species, where large-scale disturbance may be more frequent (e.g. in eastern North America and East Asia, Peters, 1992) and gap closure is not as rapid as in European beech forests. For reaching at more general conclusions about the effects of forest development on the plant species diversity in primeval forests, this case study with $F$. sylvatica should be complemented by similar investigations in temperate primeval forests composed of other tree species.

\section{Authors' contributions}

M.H. and C.L. conceived the ideas; S.K. and M.H. designed methodology; S.K. collected and analysed the data; M.H. and C.L. led the writing of the manuscript. All authors contributed critically to the drafts and gave final approval for publication. 


\section{Acknowledgements}

This study was funded by the Stemmler Foundation, a member of the Stifterverband für die Deutsche Wissenschaft. We are grateful to the Poloniny National Park administration, the Ministry of Defense of the Slovak Republic for the permission to conduct the study, and to the Technical University of Zvolen for field support. Special thanks go to Begona Aguirre-Hudson (Richmond), André Aptroot (Soest), Othmar Breuss (Vienna), Michael Lüth (Freiburg), Alan Orange (Cardiff), Christian Printzen (Frankfurt), Alfons Schäfer-Verwimp (HerdwangenSchönach), Matthias Schultz (Hamburg), Leif Tibell (Uppsala), and Tor Tønsberg (Bergen) for the confirmation of critical species. We thank two anonymous reviewers for their constructive criticism of an earlier version of the manuscript.

\section{Data accessibility}

Data is available from the Dryad Digital Repository: https://doi:10.5061/dryad.gp898f1 (Kaufmann, Hauck, \& Leuschner 2018) 


\subsection{Appendix}

Table A3.1. Absolute number $(N)$ and percentage (\%) of plots assigned to one of the three development stages (initial, optimal or terminal) within the primeval forests and the corresponding production stands in the three study areas (Havešová, Kyjov and Stužica).

\begin{tabular}{|c|c|c|c|c|c|c|c|c|}
\hline & \multicolumn{6}{|c|}{ Primeval Forests } & \multirow{2}{*}{\multicolumn{2}{|c|}{$\frac{\text { Production Forest }}{\text { Optimal }}$}} \\
\hline & \multicolumn{2}{|c|}{ Initial } & \multicolumn{2}{|c|}{ Optimal } & \multicolumn{2}{|c|}{ Terminal } & & \\
\hline & $N$ & $\%$ & $N$ & $\%$ & $N$ & $\%$ & $N$ & $\%$ \\
\hline Havešová & 11 & 27.5 & 13 & 32.5 & 16 & 40.0 & 10 & 100.0 \\
\hline Kyjov & 16 & 40.0 & 12 & 30.0 & 12 & 30.0 & 10 & 100.0 \\
\hline Stužica & 17 & 42.5 & 10 & 25.0 & 13 & 32.5 & 10 & 100.0 \\
\hline Total & 44 & 36.7 & 35 & 29.2 & 41 & 34.1 & 30 & 100.0 \\
\hline
\end{tabular}




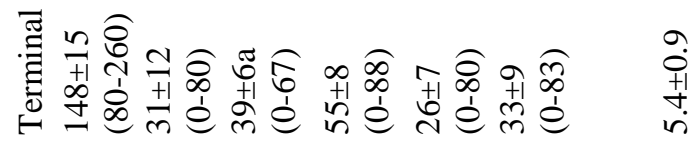


Table A3.3. Stand properties of the forest development stages (initial, optimal and terminal stages) in the primeval forests and the production forests (means of the three study areas).

\begin{tabular}{|c|c|c|c|c|c|}
\hline & \multicolumn{3}{|c|}{ Primeval forests } & \multirow{2}{*}{$\begin{array}{l}\text { Production } \\
\text { forests }\end{array}$} & \multirow[b]{2}{*}{$P$} \\
\hline & Initial & Optimal & Terminal & & \\
\hline Live trees $\left(\mathrm{ha}^{-1}\right)$ & $\begin{array}{c}175 \pm 9 a \\
(60-400)\end{array}$ & $\begin{array}{c}187 \pm 11 \mathrm{a} \\
(100-380)\end{array}$ & $\begin{array}{l}141 \pm 7 b \\
(60-260)\end{array}$ & $\begin{array}{l}328 \pm 25 c \\
(284-370)\end{array}$ & $* * *$ \\
\hline $\begin{array}{l}\text { Standing deadwood } \\
(\text { no. of snags ha-1) }\end{array}$ & $\begin{array}{c}32 \pm 3 a \\
(20-80)\end{array}$ & $\begin{array}{c}42 \pm 6 a \\
(20-120)\end{array}$ & $\begin{array}{c}35 \pm 3 a \\
(20-80)\end{array}$ & $\begin{array}{l}10 \pm 2 b \\
(0-60)\end{array}$ & $* * *$ \\
\hline Live trees, mean dbh $(\mathrm{cm})$ & $\begin{array}{c}38 \pm 1 \mathrm{a} \\
(26-79)\end{array}$ & $\begin{array}{l}46 \pm 1 b \\
(24-69)\end{array}$ & $\begin{array}{c}52 \pm 1 b \\
(34-73)\end{array}$ & $\begin{array}{l}32 \pm 2 c \\
(28-36)\end{array}$ & $* * *$ \\
\hline Standing deadwood, mean dbh $(\mathrm{cm})$ & $\begin{array}{c}39 \pm 6 a \\
(0-107)\end{array}$ & $\begin{array}{l}38 \pm 5 a \\
(0-78)\end{array}$ & $\begin{array}{c}39 \pm 6 a \\
(0-100)\end{array}$ & $\begin{array}{l}13 \pm 4 b \\
(8-21)\end{array}$ & $* *$ \\
\hline Downed deadwood $\left(\mathrm{ha}^{-1}\right)$ & $\begin{array}{c}47 \pm 5 a \\
(20-120)\end{array}$ & $\begin{array}{c}43 \pm 5 a \\
(20-120)\end{array}$ & $\begin{array}{c}39 \pm 6 a \\
(20-160)\end{array}$ & $\begin{array}{c}1 \pm 1 b \\
(0-20)\end{array}$ & $* * *$ \\
\hline $\begin{array}{l}\text { Downed deadwood, mean diameter } \\
(\mathrm{cm})\end{array}$ & $\begin{array}{c}55 \pm 4 a \\
(31-92)\end{array}$ & $\begin{array}{c}47 \pm 4 \mathrm{a} \\
(19-85)\end{array}$ & $\begin{array}{l}50 \pm 5 \mathrm{a} \\
(0-98)\end{array}$ & $\begin{array}{l}4 \pm 2 b \\
(0-63)\end{array}$ & $* * *$ \\
\hline
\end{tabular}

Means (pooled across study areas. \pm standard error) with ranges in brackets.

Levels of significance: $* P \leq 0.05$. ** $P \leq 0.01$. *** $P \leq 0.001$. Kruskal-Wallis test and additional testing with Dunn`s test for multiple comparisons for stand-structural parameters; Within a row. means followed by the same letter do not differ significantly. 
Table A3.4. Vascular plants, bryophytes and lichens (plus three non-lichenized fungi marked with '*') occurring in the three primeval ( $\mathrm{N}=120$ plots) and production ( $\mathrm{N}=30$ plots) forests Havešová, Kyjov and Stužica.

\begin{tabular}{|c|c|c|c|c|c|}
\hline \multirow[b]{2}{*}{ Species } & \multirow{3}{*}{ Code $^{\mathrm{a}}$} & \multicolumn{2}{|c|}{ Primeval $^{\mathrm{a}}$} & \multicolumn{2}{|c|}{ Production } \\
\hline & & & Free & ency & \\
\hline & & absolute & $(\%)$ & absolute & $(\%)$ \\
\hline \multicolumn{6}{|l|}{ Vascular plants: } \\
\hline Abies alba & Abi_alb & 16 & 13.3 & 4 & 13.3 \\
\hline Acer platanoides & Ace_plt & 26 & 21.7 & 22 & 73.3 \\
\hline Acer pseudoplatanus & Ace_pse & 41 & 34.2 & 23 & 76.7 \\
\hline Alliaria petiolata & All_pet & 15 & 12.5 & 11 & 36.7 \\
\hline Anemone nemorosa & Ane_nem & 40 & 33.3 & 8 & 26.7 \\
\hline Athyrium filix-femina & Ath_ff & 36 & 30.0 & 17 & 56.7 \\
\hline Atropa bella-donna & Atr_bel & 27 & 22.5 & 6 & 20 \\
\hline Carex remota & Car_rem & 2 & 1.7 & - & - \\
\hline Carex sylvatica & Car_syl & 13 & 10.8 & 7 & 23.3 \\
\hline Chelidonium majum & Che_maj & 3 & 2.5 & 6 & 20.0 \\
\hline Chrysosplenium alternifolium & Chr_alt & 2 & 1.7 & - & - \\
\hline Circaea lutetiana & Cir_lut & 3 & 2.5 & - & - \\
\hline Corydalis cava & Cor_cav & 2 & 1.7 & 3 & 10.0 \\
\hline Corylus avellana & - & - & - & 8 & 26.7 \\
\hline Daphne mezereum & Dap_mez & 1 & 0.8 & 5 & 16.7 \\
\hline Dentaria bulbifera & Den_bul & 2 & 1.7 & 18 & 60.0 \\
\hline Dentaria glandulosa & Den_gla & 58 & 48.3 & 15 & 50.0 \\
\hline Dryopteris carthusiana & Dry_car & 37 & 30.8 & - & - \\
\hline Dryopteris expensa & Dry_exp & 9 & 7.5 & - & - \\
\hline Dryopteris filix-mas & Dry_fm & 6 & 5.0 & 6 & 20.0 \\
\hline Euphorbia amygdaloides & Eup_amy & 19 & 15.8 & 16 & 53.3 \\
\hline Fagus sylvatica & Fag_syl & 116 & 96.7 & 30 & 100 \\
\hline Fraxinus excelsior & Fra_exc & 22 & 18.3 & 12 & 40.0 \\
\hline Galeopsis speciosa & Gal_spe & 1 & 0.8 & 4 & 13.3 \\
\hline Galium odoratum & Gal_odo & 45 & 37.5 & 12 & 40.0 \\
\hline Geranium robertianum & Ger_rob & 40 & 33.3 & 13 & 43.3 \\
\hline Gymnocarpium dryopteris & Gym_dry & 13 & 10.8 & 3 & 10.0 \\
\hline Impatiens glandulifera & Imp_gla & 9 & 7.5 & 2 & 6.7 \\
\hline Impatiens noli-tangere & Imp_nol & 6 & 5.0 & 2 & 6.7 \\
\hline Isopyrum thalictroides & Iso_tha & 16 & 13.3 & - & - \\
\hline Lamium galeobdolon & Lam_gal & 7 & 5.8 & 7 & 23.3 \\
\hline Lamium purpureum & Lam_pur & 12 & 10.0 & 13 & 43.3 \\
\hline Lunaria rediviva & Lun_red & 1 & 0.8 & 2 & 6.7 \\
\hline Maiantehmum bifolium & Mai_bif & 4 & 3.3 & - & - \\
\hline Mercurialis perennis & Mer_per & 14 & 11.7 & 14 & 46.7 \\
\hline Mycelis muralis & - & - & - & 11 & 36.7 \\
\hline Oxalis acetosella & Oxa_ace & 9 & 7.5 & 2 & 6.7 \\
\hline
\end{tabular}




\begin{tabular}{|c|c|c|c|c|c|}
\hline \multirow{2}{*}{$\begin{array}{l}\text { Species } \\
\text { Vascular plants: }\end{array}$} & \multirow[t]{2}{*}{ Code } & \multicolumn{2}{|c|}{ Primeval $^{\mathrm{a}}$} & \multicolumn{2}{|c|}{ Production } \\
\hline & & & & & \\
\hline Paris quadrifolia & Par_qua & 18 & 15.0 & 4 & 13.3 \\
\hline Polygonatum verticillatum & Pol_ver & 24 & 20.0 & 3 & 10.0 \\
\hline Populus tremula & Pop_tre & 3 & 2.5 & 1 & 3.3 \\
\hline Prenanthes purpurea & Pre_pur & 1 & 0.8 & - & - \\
\hline Quercus robur & - & - & - & 11 & 36.7 \\
\hline Rubus hirtus & Rub_hir & 60 & 50.0 & 13 & 43.3 \\
\hline Salvia glutinosa & Sal_glu & 46 & 38.3 & 22 & 73.3 \\
\hline Senecio ovatus & Sen_ova & 8 & 6.7 & 9 & 30.0 \\
\hline Stachys sylvatica & Sta_syl & 10 & 8.3 & 7 & 23.3 \\
\hline Stellaria media & Ste_med & 4 & 3.3 & 5 & 16.7 \\
\hline Symphytum cordatum & Sym_cor & 1 & 0.8 & - & - \\
\hline Tilia cordata & Til_cor & 1 & 0.8 & - & - \\
\hline Ulmus glabra & Ulm_gla & 4 & 3.3 & 10 & 33.3 \\
\hline Urtica dioica & Urt_dio & 7 & 5.8 & 5 & 16.7 \\
\hline Veronica officinalis & Ver_off & 2 & 1.7 & 2 & 6.7 \\
\hline Viola reichenbachiana & Vio_rei & 9 & 7.5 & 11 & 36.7 \\
\hline \multicolumn{6}{|l|}{ Mosses: } \\
\hline Amblystegium serpens & Amb_ser & 38 & 31.7 & 13 & 43.3 \\
\hline Amblystegium subtile & Amb_sub & 22 & 18.3 & 5 & 16.7 \\
\hline Amblystegium varium & Amb_var & 5 & 4.2 & - & - \\
\hline Anomodon attenuatus & Ano_att & 51 & 42.5 & 6 & 20.0 \\
\hline Anomodon longifolius & Ano_lon & 4 & 3.3 & - & - \\
\hline Anomodon rugelii & Ano_rug & 25 & 20.8 & - & - \\
\hline Anomodon viticulosus & Ano_vit & 5 & 4.2 & - & - \\
\hline Atrichum undulatum & Atr_und & 15 & 12.5 & 6 & 20 \\
\hline Brachytheciastrum velutinum & Bra_vel & 48 & 72.5 & 28 & 93.3 \\
\hline Brachythecium reflexum & Bra_ref & 6 & 6.7 & 2 & 6.7 \\
\hline Brachythecium rutabulum & Bra_rut & 87 & 40.0 & 3 & 10.0 \\
\hline Brachythecium salebrosum & Bra_sal & 8 & 31.7 & 13 & 43.3 \\
\hline Bryum moravicum & Bry_mor & 38 & 15.8 & 3 & 10.0 \\
\hline Buxbaumia viride & Bux_vir & 19 & 0.8 & - & - \\
\hline Campylium sommerfeltii & Cam_som & 21 & 17.5 & - & - \\
\hline Dicranella heteromalla & Dic_Het & 11 & 9.2 & - & - \\
\hline Dicranodontium denudatum & Dic_den & 1 & 0.8 & - & - \\
\hline Dicranum montanum & Dic_mon & 118 & 98.3 & 25 & 83.3 \\
\hline Dicranum scoparium & Dic_sco & 19 & 15.8 & 2 & 6.7 \\
\hline Dicranum viride & Dic_vir & 36 & 30.0 & - & - \\
\hline Diphyscium foliosum & Dip_fol & 1 & 0.8 & - & - \\
\hline Fissidens dubium & Fis_dub & 1 & 0.8 & - & - \\
\hline Grimmia hartmanii & Gri_har & 1 & 0.8 & - & - \\
\hline Herzogiella seligeri & Her_sel & 37 & 30.8 & 2 & 6.7 \\
\hline
\end{tabular}




\begin{tabular}{|c|c|c|c|c|c|}
\hline \multirow{2}{*}{$\begin{array}{l}\text { Species } \\
\text { Mosses: }\end{array}$} & \multirow[t]{2}{*}{ Code } & \multicolumn{2}{|c|}{ Primeval $^{\mathrm{a}}$} & \multicolumn{2}{|c|}{ Production } \\
\hline & & & & & \\
\hline Homalothecium sericeum & Hom_ser & 6 & 5.0 & - & - \\
\hline Homalia trichomanoides & Hom_tri & 2 & 1.7 & - & - \\
\hline Hypnum cupressiforme & Hyp_cup & 98 & 81.7 & 29 & 96.7 \\
\hline $\begin{array}{l}\text { Hypnum cupressiforme var. } \\
\text { filiforme }\end{array}$ & Hyp_fil & 59 & 49.2 & 6 & 20.0 \\
\hline Hypnum pallescens & Hyp_pal & 58 & 48.3 & 19 & 63.3 \\
\hline Isothecium alopecuroides & Iso_alo & 80 & 66.7 & 14 & 46.7 \\
\hline Kindbergia praelongum & Kin_pra & 2 & 1.7 & 1 & 3.3 \\
\hline Leskea polycarpa & - & - & - & 1 & 3.3 \\
\hline Leucodon sciuroides & Leu_sci & 22 & 18.3 & 1 & 3.3 \\
\hline Mnium hornum & - & - & - & 1 & 3.3 \\
\hline Neckera besseri & Nec_bes & 11 & 9.2 & - & - \\
\hline Neckera complanata & Nec_com & 4 & 3.3 & - & - \\
\hline Neckera crispa & Nec_cri & 3 & 2.5 & - & - \\
\hline Neckera pennata & Nec_pen & 7 & 5.8 & - & - \\
\hline Neckera pumila & Nec_pum & 1 & 0.8 & - & - \\
\hline Orthotrichum affine & Ort_aff & 2 & 1.7 & 1 & 3.3 \\
\hline Orthotrichum anomalum & Ort_ano & 1 & 0.8 & - & - \\
\hline Orthotrichum lyellii & Ort_lye & 10 & 8.3 & 8 & 26.7 \\
\hline Orthotrichum obtusifolium & Ort_obt & 3 & 2.5 & - & - \\
\hline Orthotrichum pallens & Ort_pall & 2 & 1.7 & 2 & 6.7 \\
\hline Orthotrichum patens & - & - & - & 2 & 6.7 \\
\hline Orthotrichum pumilum & Ort_pum & 1 & 0.8 & - & - \\
\hline Orthotrichum speciosum & Ort_spe & 1 & 0.8 & - & - \\
\hline Orthotrichum stramineum & Ort_str & 19 & 15.8 & 5 & 16.7 \\
\hline Orthotrichum striatum & - & - & - & 1 & 3.3 \\
\hline Paraleucobryum longifolium & Par_lon & 111 & 92.5 & 12 & 40.0 \\
\hline Plagiomnium cuspitatum & Pla_cus & 6 & 5.0 & - & - \\
\hline Plagiothecium cavifolium & Pla_cav & 1 & 0.8 & - & - \\
\hline Plagiothecium curvifolium & Pla_cur & 26 & 21.7 & 2 & 6.7 \\
\hline Plagiothecium denticulatum & Pla_den & 28 & 23.3 & - & - \\
\hline Plagiothecium laetum & Pla_lae & 42 & 35.0 & - & - \\
\hline Plagiothecium nemorale & Pla_nem & 2 & 1.7 & - & - \\
\hline Plagiothecium succulentum & Pla_suc & 7 & 5.8 & - & - \\
\hline Platygyrium repens & Pla_rep & 80 & 66.7 & 18 & 60.0 \\
\hline Pogonatum aloides & Pog_alo & 4 & 3.3 & - & - \\
\hline Polytrichum formosum & Pol_for & 9 & 7.5 & 2 & 6.7 \\
\hline Pseudoleskeella nervosa & Pse_ner & 49 & 40.8 & 21 & 70.0 \\
\hline Pterigynandrum filiforme & Pte_fil & 116 & 96.7 & 30 & 100.0 \\
\hline Rhizomnium punctatum & Rhi_pun & 28 & 23.3 & - & - \\
\hline Sanionia uncinata & San_unc & 20 & 16.7 & 1 & 3.3 \\
\hline Sciro-hypnum populeum & S-H_pop & 65 & 54.2 & 7 & 23.3 \\
\hline
\end{tabular}




\begin{tabular}{|c|c|c|c|c|c|}
\hline \multirow{2}{*}{$\frac{\text { Species }}{\text { Mosses: }}$} & \multirow[t]{2}{*}{ Code } & \multicolumn{2}{|c|}{ Primeval $^{\mathrm{a}}$} & \multicolumn{2}{|c|}{ Production } \\
\hline & & & & & \\
\hline Tetraphis pellucida & Tet_pel & 2 & 1.7 & - & - \\
\hline Ulota bruchii & Ulo_bru & 9 & 7.5 & 3 & 10.0 \\
\hline Ulota crispa & Ulo_cri & 2 & 1.7 & - & - \\
\hline Zygodon rupestris & Zyg_rup & 7 & 5.8 & 1 & 3.3 \\
\hline \multicolumn{6}{|l|}{ Liverworts: } \\
\hline Blepharostomum trichophyllum & Ble_tri & 6 & 5.0 & - & - \\
\hline Calypogeia muelleriana & Cal_mue & 1 & 0.8 & - & - \\
\hline Calypogeia suecica & Cal_sue & 4 & 3.3 & - & - \\
\hline Cephalozia bicuspitata & Cep_bic & 5 & 4.2 & - & - \\
\hline Chiloscyphus polyanthus & Chi_pol & 1 & 0.8 & - & - \\
\hline Frullania dilatata & Frau_dil & 51 & 42.5 & 9 & 30.0 \\
\hline Lophocolea bidentata & Lop_bid & 8 & 6.7 & 1 & 3.3 \\
\hline Lophocolea heterophylla & Lop_het & 81 & 67.5 & 18 & 60.0 \\
\hline Metzgeria conjugata & Met_con & 24 & 20.0 & - & - \\
\hline Metzgeria furcata & Met_fur & 97 & 80.8 & 18 & 60.0 \\
\hline Nowellia curvifolia & Now_cur & 1 & 0.8 & - & - \\
\hline Plagiochila porelloides & Pla_por & 4 & 3.3 & - & - \\
\hline Porella arboris-vitae & Por_avi & 2 & 1.7 & - & - \\
\hline Porella platyphylla & Por_pla & 28 & 23.3 & 1 & 3.3 \\
\hline Ptilidium pulcherrimum & Pti_pul & 2 & 1.7 & 1 & 3.3 \\
\hline Radula complanata & Rad_com & 55 & 45.8 & 21 & 70.0 \\
\hline Riccardia palmata & Ric_pal & 13 & 10.8 & 1 & 3.3 \\
\hline
\end{tabular}

Lichens:

$\begin{array}{llllll}\text { Acrocordia gemmata } & \text { Acr_gem } & 1 & 0.8 & 1 & 3.3 \\ \text { Alyxoria varia } & \text { Aly_var } & 4 & 3.3 & - & - \\ \text { Amandinea punctata } & \text { Ama_pun } & 11 & 9.2 & 6 & 20.0 \\ \text { Anisomeridium biforme } & \text { Ani_bif } & 10 & 8.3 & - & - \\ \text { Anisomeridium polypori } & \text { Ani_pol } & 2 & 1.7 & 1 & 3.3 \\ \text { Arthonia didyma } & \text { Art_did } & 3 & 2.5 & - & - \\ \text { Arthonia radiata } & \text { Art_rad } & 3 & 2.5 & 5 & 16.7 \\ \text { Arthonia spadicea } & \text { Art_spa } & 24 & 20.0 & 2 & 6.7 \\ \text { Bacidia rubella } & \text { Bac_rub } & 1 & 0.8 & - & - \\ \text { Bacidia subincompta } & \text { Bac_sub } & 1 & 0.8 & - & - \\ \text { Bacidina chloroticula } & \text { Bac_chl } & 1 & 0.8 & - & - \\ \text { Belonia herculina } & \text { Bel_her } & 11 & 9.2 & - & - \\ \text { Biatora veteranorum } & \text { Bia_ver } & 1 & 0.8 & - & - \\ \text { Biatoridium monasteriense } & \text { Bia_mon } & 2 & 1.7 & - & - \\ \text { Buellia griseovirens } & \text { Bue_gri } & 3 & 2.5 & - & - \\ \text { Calicium montanum } & \text { Cal_mon } & 3 & 2.5 & - & - \\ \text { Calicium salicinum } & \text { Cal_sal } & 3 & 2.5 & - & -\end{array}$




\begin{tabular}{|c|c|c|c|c|c|}
\hline \multirow{2}{*}{$\begin{array}{l}\text { Species } \\
\text { Lichens: }\end{array}$} & Code & \multicolumn{2}{|c|}{ Primeval $^{\mathrm{a}}$} & \multicolumn{2}{|c|}{ Production } \\
\hline & & & & & \\
\hline Candelariella xanthostigma & Can_xan & 5 & 4.2 & - & - \\
\hline Chaenotheca brachypoda & Cha_bra & 2 & 1.7 & - & - \\
\hline Chaenotheca brunneola & Cha_bru & 4 & 3.3 & - & - \\
\hline Chaenotheca trichialis & Cha_tri & 1 & 0.8 & - & - \\
\hline Chaenotheca xyloxena & Cha_xyl & 9 & 7.5 & 1 & 3.3 \\
\hline *Chaenothecopsis pusilla & Cha_pusi & 6 & 5.0 & 1 & 3.3 \\
\hline *Chaenothecopsis pusiola & Cha_pu & 1 & 0.8 & 1 & 3.3 \\
\hline Chrysotrix candelaris & Chr_can & 3 & 2.5 & - & - \\
\hline Cladonia chlorophaea & Cla_chl & 7 & 5.8 & - & - \\
\hline Cladonia coniocraea & Cla_con & 37 & 30.8 & 2 & 6.7 \\
\hline Cladonia digitata & Cla_dig & 3 & 2.5 & - & - \\
\hline Cladonia fimbriata & Cla_fim & 27 & 22.5 & 1 & 3.3 \\
\hline Coenogonium pineti & Coe_pin & 31 & 25.8 & 8 & 26.7 \\
\hline Dictyocatenulata alba & Dic_cat & 18 & 15.0 & - & - \\
\hline Eopyrenula leucoplaca & Eop_leu & 1 & 0.8 & - & - \\
\hline Evernia prunastri & Eve_pru & 3 & 2.5 & - & - \\
\hline Graphis scripta & Gra_scr & 112 & 93.3 & 30 & 100.0 \\
\hline Hyperphyscia adglutinosa & Hyp_adg & 1 & 0.8 & - & - \\
\hline Hypocenomyce scalaris & Hyp_sca & 2 & 1.7 & - & - \\
\hline Hypogymnia physodes & Hyp_phy & 7 & 5.8 & 2 & 6.7 \\
\hline Lecania cyrtella & Lec_cyr & 4 & 3.3 & - & - \\
\hline Lecanora argentata & Lec_arg & 0 & 0.8 & - & - \\
\hline Lecanora chlarotera & Lec_chl & 1 & 0.8 & - & - \\
\hline Lecanora compallens & Lec_com & 2 & 1.7 & - & - \\
\hline Lecanora conizaeoides & Lec_con & 9 & 7.5 & 1 & 3.3 \\
\hline Lecanora glabrata & Lec_gla & 10 & 8.3 & - & - \\
\hline Lecanora horiza & Lec_hor & 1 & 0.8 & - & - \\
\hline Lecanora pulicaris & Lec_pul & 3 & 2.5 & 2 & 6.7 \\
\hline Lecanora subrugosa & Lec_sub & 3 & 2.5 & 1 & 3.3 \\
\hline Lecidea albohyalina & Lec_alb & 1 & 0.8 & - & - \\
\hline Lecidella elaeochroma & Lec_ela & 2 & 1.7 & 2 & 6.7 \\
\hline Lepraria incana & Lep_inc & 99 & 82.5 & 9 & 30.0 \\
\hline Lepraria lobificans & Lep_lob & 22 & 18.3 & 3 & 10.0 \\
\hline Leptogium cyanescens & Lep_cya & 4 & 3.3 & - & - \\
\hline Loxospora elatina & Lox_ela & 2 & 1.7 & - & - \\
\hline Melanelixia glabratula & Mel_gla & 15 & 12.5 & 11 & 36.7 \\
\hline Melanohalea elegantula & Mel_ele & 7 & 5.8 & 5 & 16.7 \\
\hline Micarea peliocarpa & Mic_el & 1 & 0.8 & - & - \\
\hline Micarea prasina & Mic_pra & 1 & 0.8 & - & - \\
\hline Multiclavula mucida & Mul_muc & 3 & 2.5 & - & - \\
\hline *Mycocalicium subtile & Myc_sub & 2 & 1.7 & - & - \\
\hline Ochrolechia subviride & Och_sub & 6 & 5.0 & - & - \\
\hline
\end{tabular}




\begin{tabular}{|c|c|c|c|c|c|}
\hline \multirow{2}{*}{$\begin{array}{l}\text { Species } \\
\text { Lichens: }\end{array}$} & \multirow[t]{2}{*}{ Code } & \multicolumn{2}{|c|}{ Primeval $^{\mathrm{a}}$} & \multicolumn{2}{|c|}{ Production } \\
\hline & & & & & \\
\hline Parmelia saxatilis & Par_sax & 1 & 0.8 & - & - \\
\hline Parmelia sulcata & Par_sul & 2 & 1.7 & 3 & 10.0 \\
\hline Parmelina tiliaceae & - & - & - & 1 & 3.3 \\
\hline Pertusaria albescens & Per_alb & 2 & 1.7 & - & - \\
\hline Pertusaria flavida & Per_fla & 1 & 0.8 & - & - \\
\hline Pertusaria leioplaca & Per_lei & 5 & 4.2 & 6 & 20.0 \\
\hline Pertusaria pustulata & Per_pus & 1 & 0.8 & - & - \\
\hline Pertusaria sommerfeltii & Per_som & 1 & 0.8 & - & - \\
\hline Phaeophyscia ciliata & Pha_cil & 4 & 3.3 & - & - \\
\hline Phaeophyscia endophoenicea & Pha_end & 1 & 0.8 & 3 & 10.0 \\
\hline Phaeophyscia orbicularis & Pha_orb & 1 & 0.8 & 5 & 16.7 \\
\hline Phlyctis argena & Phy_arg & 53 & 44.2 & 13 & 43.3 \\
\hline Physcia adscendens & Phy_ads & 1 & 0.8 & 12 & 40.0 \\
\hline Physcia tenella & Phy_ten & 1 & 0.8 & 5 & 16.7 \\
\hline Physciella chloantha & - & - & - & 1 & 3.3 \\
\hline Porina aenea & Por_aen & 11 & 9.2 & 10 & 33.3 \\
\hline Porina leptalea & Por_lep & 2 & 1.7 & - & - \\
\hline Pseudosagedia borreri & Pse_bor & 1 & 0.8 & - & - \\
\hline Pyrenula laevigata & Pyr_lae & 1 & 0.8 & - & - \\
\hline Pyrenula nitida & Pyr_nit & 96 & 80.0 & 16 & 53.3 \\
\hline Sclerophora peronella & Scl_per & 1 & 0.8 & - & - \\
\hline Scoliciosporum sarothamni & Sco_sar & 2 & 1.7 & - & - \\
\hline Scoliciosporum umbrinum & Sco_umb & 5 & 4.2 & - & - \\
\hline Scytinium aragonii & Scy_ara & 2 & 1.7 & - & - \\
\hline Thelocarpon epibolum & The_epi & 2 & 1.7 & 1 & 3.3 \\
\hline Thelotrema lepadinum & The_lep & 2 & 1.7 & - & - \\
\hline Varicellaria hemisphaerica & Var_hem & 3 & 2.5 & - & - \\
\hline Zwackhia viridis & Zwa_vir & 1 & 0.8 & - & - \\
\hline
\end{tabular}

${ }^{a}$ Species abbreviations used in CCA diagrams. 


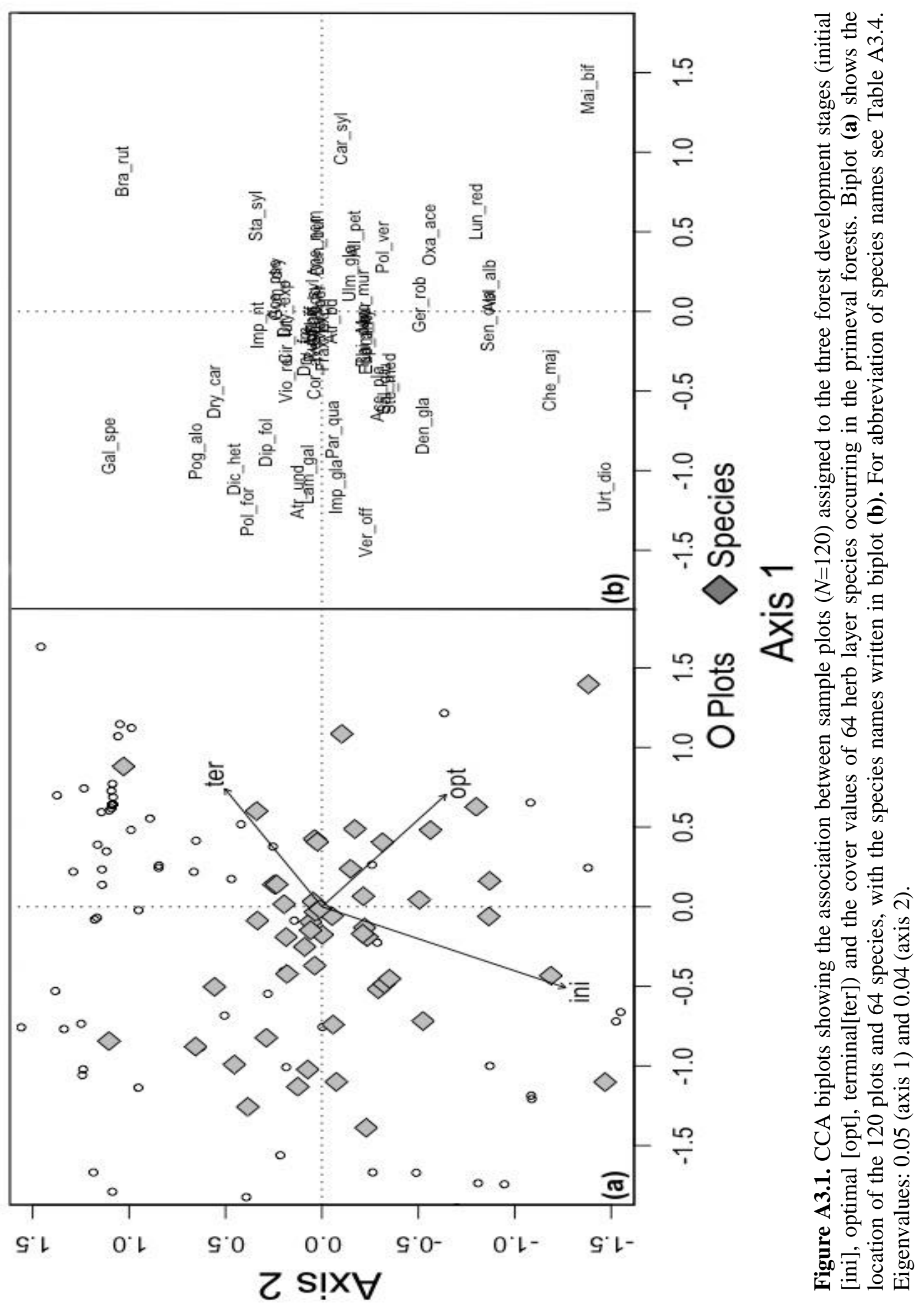




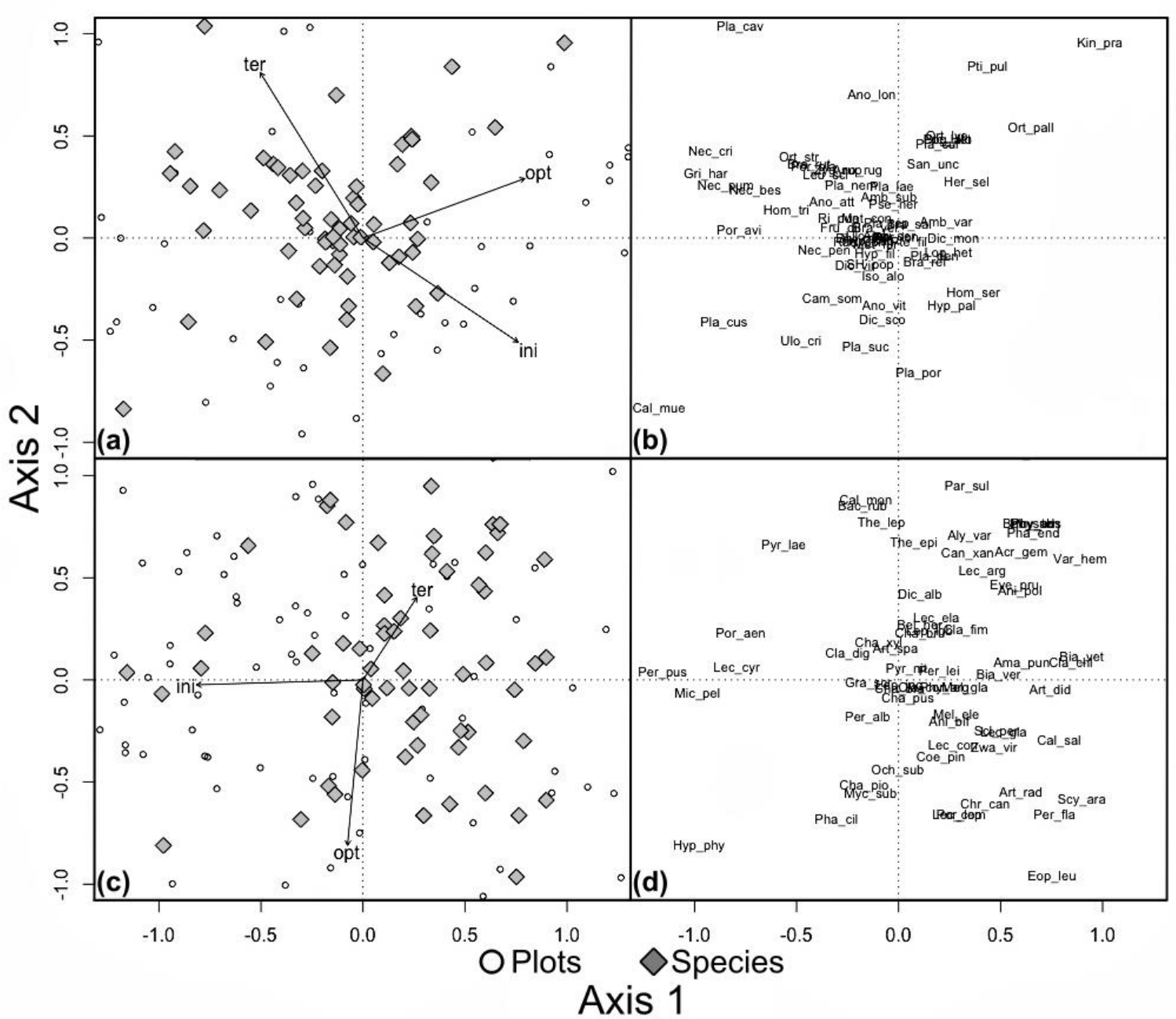

Figure A3.2. CCA biplots showing the association between sample plots $(N=120)$ assigned to the three forest development stages (initial [ini], optimal [opt], terminal[ter]) and the presence of (a, b) epiphytic bryophytes and (c, d) lichens occurring in three primeval forests. Biplots (a) and (c) show the location of the 120 plots and epiphyte species, with the species names written in biplots (b) and (d).

Circles indicate plots $(N=120)$, diamonds bryophyte or lichen species. For abbreviations of species names see Table A3.4. Bryophytes: eigenvalues 0.05 (axis 1), 0.02 (axis 2); lichens: eigenvalues 0.06 (axis 1), 0.05 (axis 2). 


\section{References}

Abrams, W.G. \& Dickmann, D.I. (1982). Early revegetation of clear-cut and burned jack-pine sites in northern lower Michigan. Canadian Journal of Botany, 60, 946-954.

Aragón, G., Martínez, I., Izquierdo, P., Belinchón, R. \& Escudero, A. (2010). Effects of forest management on epiphytic lichen diversity in Mediterranean forests. Applied Vegetation Science, 13, 183-194.

Barbour, M.G. \& Billings, D.W. (2000). North American Terrestrial Vegetation, $2^{\text {nd }}$ ed. Cambridge Univ. Press, 708 p.

Battles, J.J., Shlisky, A.J., Barett, R.H., Heald, R.C. \& Allen-Diaz, B.H. (2001). The effects of forest management on plant species diversity in a Sierran conifer forest. Forest Ecology and Management, 146, 211-222.

Beatty, S. (2014). Habitat heterogeneity and maintenance of species in understory communitites. In: Gilliam, F.S. (Ed.) The Herbaceous Layer in Forests of Eastern North America (2nd ed., pp. 215-232). Oxford Univ. Press, Oxford.

Boch, S., Prati, D., Müller, J., Socher, S., Baumbach, H. \& Buscot, F. (2013). High plant species richness indicates management-related disturbances rather than the conservation status of forests. Basic and Applied Ecology, 14, 496-505.

Brunet, J., Falkengren-Grerup, U. \& Tyler, G. (1996). Herb layer vegetation of south Swedish beech and oak forests - Effects of management and soil acidity during one decade. Forest Ecology and Management, 88, 259-272.

Brunet, J., Fritz, Ö. \& Richnau, G. (2010). Biodiversity in European beech forests - a review with recommendations for sustainable forest management. Ecological Bulletins, 53, $77-$ 94.

Brunet, J., Fritz, Ö. \& Richnau, G. (2010). Biodiversity in European beech forests - a review with recommendations for sustainable forest management. Ecological Bulletins, 53, 7794.

Chao, A., Gotelli, N.J., Hsieh, T.C., Sander, E.L., Ma, K.H. \& Colwell, R.K. (2014). Rarefaction and extrapolation with Hill numbers: A framework for sampling and estimation in species diversity studies. Ecological Monographs, 84, 45-67. 
Colwell, R.K., Chao, A., Gotelli, N.J., Lin, S.Y., Mao, C.X. \& Chazdon, R.L. (2012). Models and estimators linking individual-based and sample-based rarefaction, extrapolation and comparison of assemblages. Journal of Plant Ecology, 5, 3-21.

Connell, J.H. (1978). Diversity in tropical rainforests and coral reefs. Science, 199, 1302-1310.

Danihelka, J., Chrtek, J. \& Kaplan, Z. (2012). Checklist of vascular plants of the Czech Republic. Preslia, 84, 647-811.

Decocq, G., Aubert, M., Dupont, F., Alard, D., Saguez, R., Wattez-Franger, A., De Foucault, B., Delelis-Dusollier, A. \& Bardat, J. (2004). Plant diversity in a managed temperate deciduous forest: Understorey response to two silvicultural systems. Journal of Applied Ecology, 41, 1065-1079.

Degen, T., Devillez, F. \& Jacquemart, A.L. (2010). Gaps promote plant diversity in beech forests Luzulo-Fagetum, North Vosges, France. Silvae Genetica, 59, 175-182.

Dymytrova, L., Nadyeina, O., Hobi, M.L. \& Scheidegger, C. (2014). Topographic and foreststand variables determining epiphytic lichen diversity in the primeval beech forest in the Ukrainian Carpathians. Biodiversity and Conservation, 23, 1367-1394.

Dittrich, S., Hauck, M., Jacob, M., Rommerskirchen, A. \& Leuschner, C. (2013). Response of ground vegetation and epiphyte diversity to natural age dynamics in a Central European mountain spruce forest. Journal of Vegetation Science, 24, 675-687.

Dufrêne, M. \& Legendre, P. (1997). Species assemblages and indicator species: the need for a flexible asymmetrical approach. Ecological Monographs, 67, 345-366.

Dusan, R., Stjepan, M., Igor, A.N.I.Ć. \& Jurij, D. (2007). Gap regeneration patterns in relationship to light heterogeneity in two old-growth beech - fir forest reserves in South East Europe. Forestry, 80, 431-443.

Elix, J. A., Kalb K., Rupprecht J. \& Schobert, R. (2012). LIAS metabolites - A Database for the Rapid Identification of Secondary Metabolites of Lichens ed. Rambold, G. liaslight.lias.net/Identification/Navikey/Metabolites/.

Feldmann, E., Glatthorn, J., Hauck, M., \& Leuschner, C. (2018). A novel empirical approach for determining the extension of different forest development stages in old-growth forests. European Journal of Forest Research, 135, 23-49.

Franklin, J.F., Spies, T.A., Pelt, R. Van, Carey, A.B., Thornburgh, D.A., Berg, D.R., Lindenmayer, D.B., Harmon, M.E., Keeton, W.S., Shaw, D.C., Bible, K. \& Chen, J. 
(2002). Disturbances and structural development of natural forest ecosystems with silvicultural implications, using Douglas-fir forests as an example. Forest Ecology and Management, 155, 399-423.

Freschet, G.T., Östlund, L., Kirchenin, E. \& Wardle, D.A. (2013). Aboveground and belowground legacies of native Sami land use on boreal forest in Northern Sweden 100 years after abandonment. Ecology, 95, 963-977.

Friedel, A., Oheimb, G. V., Dengler, J. \& Härdtle, W. (2006). Species diversity and species composition of epiphytic bryophytes and lichens - A comparison of managed and unmanaged beech forests in NE Germany. Feddes Repertorium, 117, 172-185.

Fritz, Ö., Brunet, J. \& Caldiz, M. (2009a). Interacting effects of tree characteristics on the occurrence of rare epiphytes in a Swedish beech forest area. The Bryologist, 112, 488505.

Fritz, Ö., Niklasson, M. \& Churski, M. (2009b). Tree age is a key factor for the conservation of epiphytic lichens and bryophytes in beech forests. Applied Vegetation Science, 12, 93106.

Gilliam, F.S., Turill, N.L., \& Adams, M.B. (1995). Herbaceous-layer and overstorey species in clear-cut and mature central Appalachian hardwood forests. Ecological Applications, 5, 947-955.

Glatthorn, J., Pichler, V., Hauck, M. \& Leuschner, C. (2017a). Effects of forest management on stand leaf area: Comparing beech production and primeval forests in Slovakia. Forest Ecology and Management, 389, 76-85.

Glatthorn, J., Feldmann, E., Pichler, V., Hauck, M. \& Leuschner, C. (2017b). Biomass stock and productivity of primeval and production beech forests: Greater canopy structural diversity promotes productivity. Ecosystems, 20, 1-19.

Guttová, A., Lackovicová, A. \& Pisút, I. (2013). Revised and updated checklist of lichens of Slovakia. Biologia, 68, 845-850.

Halpern, C.B. \& Spies, T.A. (2008). Plant species diversity in natural and managed forests of the Pacific Northwest. Ecological Applications, 5, 913-934.

Hauck, M. (2011). Site factors controlling epiphytic lichen abundance in northern coniferous forests. Flora, 206, 81-90. 
Hilmo, O. \& Såstad, S.M. (2001). Colonization of old-forest lichens in a young and an old boreal Picea abies forest: and experimental approach. Biological Conservation, 102, 251259.

Hilmo, O. (2002). Growth and morphological response of old-forest lichens transplanted into a young and an old Picea abies forest. Ecography, 25, 329-335.

Hodgetts, N. (2015). Checklist and country status of European bryophytes - towards a new Red List for Europe. Irish Wildl. Manuals, 84. National Parks and Wildlife Service, Department of Arts, Heritage and the Gaeltacht, Ireland.

Hofmeister, J., Hošek, J., Holá, E. \& Novozámská, E. (2015). Decline in bryophyte diversity in predominant types of central European managed forests. Biodiversity and Conservation, 24, 1391-1402.

Hsieh, T.C., Ma, K.H. \& Chao, A. (2015). Interpolation and Extrapolation for Species Diversity. R-Package "iNEXT."

Johansson, P., Rydin, H. \& Thor, G. (2007). Tree age relationships with epiphytic lichen diversity and lichen life history traits on ash in southern Sweden. Ecoscience, 14, 81-91.

Jonsson, B.G., Kruys, N. \& Ranius, T. (2005). Ecology of species living on dead wood Lessons for dead wood management. Silva Fennica, 39, 289-309.

Kaplan, J.O., Krumhardt, K.M. \& Zimmermann, N. (2009). The prehistoric and preindustrial deforestation of Europe. Quaternary Science Reviews, 28, 3016-3034.

Kaufmann, S., Hauck, M. \& Leuschner, Ch. (2017). Comparing the plant diversity of paired beech primeval and production forests: management reduces cryptogam, but not vascular plant species richness. Forest Ecology and Management, 400, 58-67.

Kaufmann, S., Hauck, M., \& Leuschner, Ch. (2018) Data from: Effects of natural forest dynamics on vascular plant, bryophyte, and lichen diversity in primeval Fagus sylvatica forests and comparison with production forests. Journal of Ecology doi:10.5061/dryad.gp898f1

Kelemen, K., Mihók, B., Galhidy, L. \& Standovár, T. (2012). Dynamic response of herbaceous vegetation to gap opening in a central European beech stand. Silva Fennica, 46, 53-65.

Kenderes, K., Král, K., Vrška, T. \& Standovár, T. (2009). Natural gap dynamics in a Central European mixed beech - spruce - fir old-growth forest. Ecoscience, 16, 39-47.

Korpel, S. (1995). Die Urwälder der Westkarpathen. Fischer Verlag, Stuttgart. 
Kucbel, S., Saniga, M., Jaloviar, P. \& Vencurik, J. (2012). Stand structure and temporal variability in old-growth beech-dominated forests of the northwestern Carpathians: A 40-years perspective. Forest Ecology and Management, 264, 125-133.

Kuuluvainen, T. (2009) Forest management and biodiversity conservation based on natural ecosystem dynamics in northern Europe: The complexity challenge. AMBIO: A journal of the Human Environment, 38, 309-315.

Leibundgut, H. (1993) Europäische Urwälder - Wegweiser zur naturnahen Waldwirtschaft. Paul Haupt, Bern.

Leuschner, C. \& Ellenberg, H. (2017). Ecology of Central European Forests. Vegetation Ecology of Central Europe, vol. I. Springer Nature, Cham. 971 p.

Leuschner, C. \& Lendzion, J. (2009). Air humidity, soil moisture and soil chemistry as determinants of the herb layer composition in European beech forests. Journal of Vegetation Science, 20, 288-298.

Marušák, R. (2007). Alternative harvest scheduling for final cut with respect to silvicultural requirements. Forstwissenschaftliches Zentralblatt vereinigt mit Tharandter forstliches Jahrbuch, 121, 301-321.

Meyer, P. (1999) Bestimmung der Waldentwicklungsphasen und der Texturdiversität in Naturwäldern. Allgemeine Forst- und Jagdzeitung, 170, 203-211.

Meyer, P., Ackermann, J., Balcar, P., Boddenberg, J., Detsch, R., Förster, B., Fuchs, H., Hoffmann, B., Keitel, W., Kölbel, M., Köthke, C., Koss, H., Unkrig, J., Weber, J. \& Willig, J. (2001). Untersuchungen der Waldstruktur und ihrer Dynamik in Naturwaldreservaten. Arbeitskreis Naturwälder. Bund-Länder-Arbeitsgemeinschaft Forsteinrichtung. IHW-Verlag.

Moning, C., Werth, S., Dziock, F., Bässler, C., Bradtka, J. \& Hothorn, T. (2009). Lichen diversity in temperate montane forests is influenced by forest structure more than climate. Forest Ecology and Management, 258, 745-751.

Naaf, T. \& Wulf, M. (2007). Effects of gap size, light and herbivory on the herb layer vegetation in European beech forest gaps. Forest Ecology and Management, 244, 141-149.

Nagaike, T., Kamitani, T. \& Nakashizuka, T. (1999). The effect of shelterwood logging on the diversity of plant species in a beech (Fagus crenata) forest in Japan. Forest Ecology and Management, 118, 161-171. 
National Forest Centre (2009). Forests in Slovakia. - Ministry of agriculture of the Slovak Republic, Bratislava.

Neuhäusl, R., Dierschke, H. \& Barkman, J.J. (1982). Chorological phenomena in plant communities: Proceedings of 26th International Symposium of the International Association for Vegetation Science, Prague, Czech Republic.

Ódor, P. \& van Hees, A.F.M. (2004). Preferences of dead wood inhabiting bryophytes for decay stage, log size and habitat types in Hungarian beech forests. Journal of Bryology, 26, 7995.

Ódor, P., Dort, K. Van, Aude, E., Heilmann-Clausen, J. \& Christensen, M. (2005). Diversity and Composition of Dead Wood Inhabiting. Boletín de la Sociedad Española de Briología, 26-27, 85-102.

Ódor, P., Heilmann-Clausen, J., Christensen, M., Aude, E., van Dort, K.W., Piltaver, A., Siller, I., Veerkamp, M.T., Walleyn, R., Standovár, T., van Hees, A.F.M., Kosec, J., Matočec, N., Kraigher, H. \& Grebenc, T. (2006). Diversity of dead wood inhabiting fungi and bryophytes in semi-natural beech forests in Europe. Biological Conservation, 131, 5871.

Ódor, P., Kiraly, I., Tinya, F., Bortignon, F. \& Nascimbene, J. (2014). Reprint of: Patterns and drivers of species composition of epiphytic bryophytes and lichens in managed temperate forests. Forest Ecology and Management, 321, 42-51.

Oksanen, J., Guillaume Blanchet, F., Friendly, M., Kindt, R., Legendre, P., McGlinn, D., Minchin, P.R., O'Hara, R. B., Simpson, G.L., Solymos, P., Stevens, M.H.H., Szoecs, E. \& Wagner, H. (2016). vegan: Community Ecology Package. R package version 2.4-3. https://CRAN.R-project.org/package=vegan.

Orange, A., James, P.W. \& White, F.J. (2001). Microchemical methods for the identification of lichens. British Lichen Society. London. $101 \mathrm{pp}$.

Pach, M. \& Podlaski, R. (2015). Tree diameter structural diversity in Central European forests with Abies alba and Fagus sylvatica: managed versus unmanaged forest stands. Ecological Research, 30, 367-384.

Paillet, Y., Bergès, L., Hjältén, J., Ódor, P., Avon, C. \& Bernhardt-Römermann, M. (2010). Biodiversity differences between managed and unmanaged forests: Meta-analysis of species richness in Europe. Conservation Biology, 24, 101-112. 
Parviainen, J. (2005). Virgin and natural forests in the temperate zone of Europe. Forest Snow and Landscape Research, 79, 9-18.

Peters, R. (1992). Ecology of beech forests in the northern hemisphere. $\mathrm{PhD}$ thesis, Wageningen.

Petráš, R. \& Pajtík, J. (1991). Sústava Česko-slovenských objemových tabuliek drevín. Lesnícky Časopis, 37, 49-56.

Roberts, M. \& Gilliam, F.S. (1995a). Patterns and mechanisms of plant diversity in forested ecosystems: implications for forest management. Ecological Applications, 5, 969-977.

Roberts, M.R. \& Gilliam, F.S., (1995b). Disturbance effects on herbaceous layer vegetation and soil nutrients in Populus forests of northern lower Michigan. Journal of Vegetation Science, 6, 903-912.

Gilliam, F.S., \& Roberts, M.R. (2014). Interactions between the herbaceous layer and overstory canopy of eastern forests. In: Gilliam, F.S. (Ed.) The Herbaceous Layer in Forests of Eastern North America. (2nd ed., pp. 233-254). Oxford Univ. Press, Oxford.

Roberts, M.R. \& Gilliam, F.S. (2014). Response of the herbaceous layer to disturbance in eastern forests. In: Gilliam, F.S. (Ed.) The Herbaceous Layer in Forests of Eastern North America. (2nd ed., 321-339). Oxford Univ. Press, Oxford.

Rose, F. (1992). Temperate forest management: its effects on bryophyte and lichen floras and habitats. 211-233. In Bates, J.W. \& Farmer, A.M., editors. Bryophytes and Lichens in a Changing Environment. Clarendon, Oxford, UK.

Röhrig, E., Lüpke, B. \& Bartsch, N. (2006) Waldbau auf ökologischer Grundlage. Ulmer, Stuttgart.

Scheller, R.M. \& Mladenoff, D.J. (2002). Understory species patterns and diversity in oldgrowth and managed northern hardwood forests. Ecological Applications, 12, 1329-1343.

Schmidt, W. (2005). Herb layer species as indicators of biodiversity of managed and unmanaged forests. Forest Snow and Landscape Research, 79, 111-125.

Slezák, M., Hrivnák, R., Ujházy, K., Ujházyyová, M., Máliš, F. \& Petrášová, A. (2016). Syntaxonomy and ecology of acidophilous beech forest vegetation in Slovakia. Phytocoenologia, 46, 69-88.

Stock Map Agency, (2007). Population density map of Slovakia. http://www.stockmapagency.com/Population_Map_Slovakia_C-Slovak-2007-Pop.php 
Trotsiuk, V., Hobi, M.L. \& Commarmot, B. (2012). Age structure and disturbance dynamics of the relic virgin beech forest Uholka (Ukrainian Carpathians). Forest Ecology and Management, 265, 181-190.

Venables, W.N. \& Ripley, B.D. (2002) Modern Applied Statistics with S. $4^{\text {th }}$ Edition. Springer, New York.

Vološčuk, I. (2014). Joint Slovak-Ukraine-Germany Beech Ecosystems as the World Natural Heritage. Ekologia, 33, 286-300.

Von Oheimb, G., Härdtle, W., Eckstein, D., Engelke, H.-H., Hehnke, T., Wagner, B. \& Fichtner, A. (2014). Does forest continuity enhance the resilience of trees to environmental change? PLOS ONE, 9.

Wiklund, K. \& Rydin, H. (2004). Ecophysiological constraints on spore establishment in bryophytes. Functional Ecology, 18, 907-913. 


\section{Chapter 4}

\section{Vertical variation in epiphytic cryptogam species richness and composition in a primeval Fagus sylvatica forest}

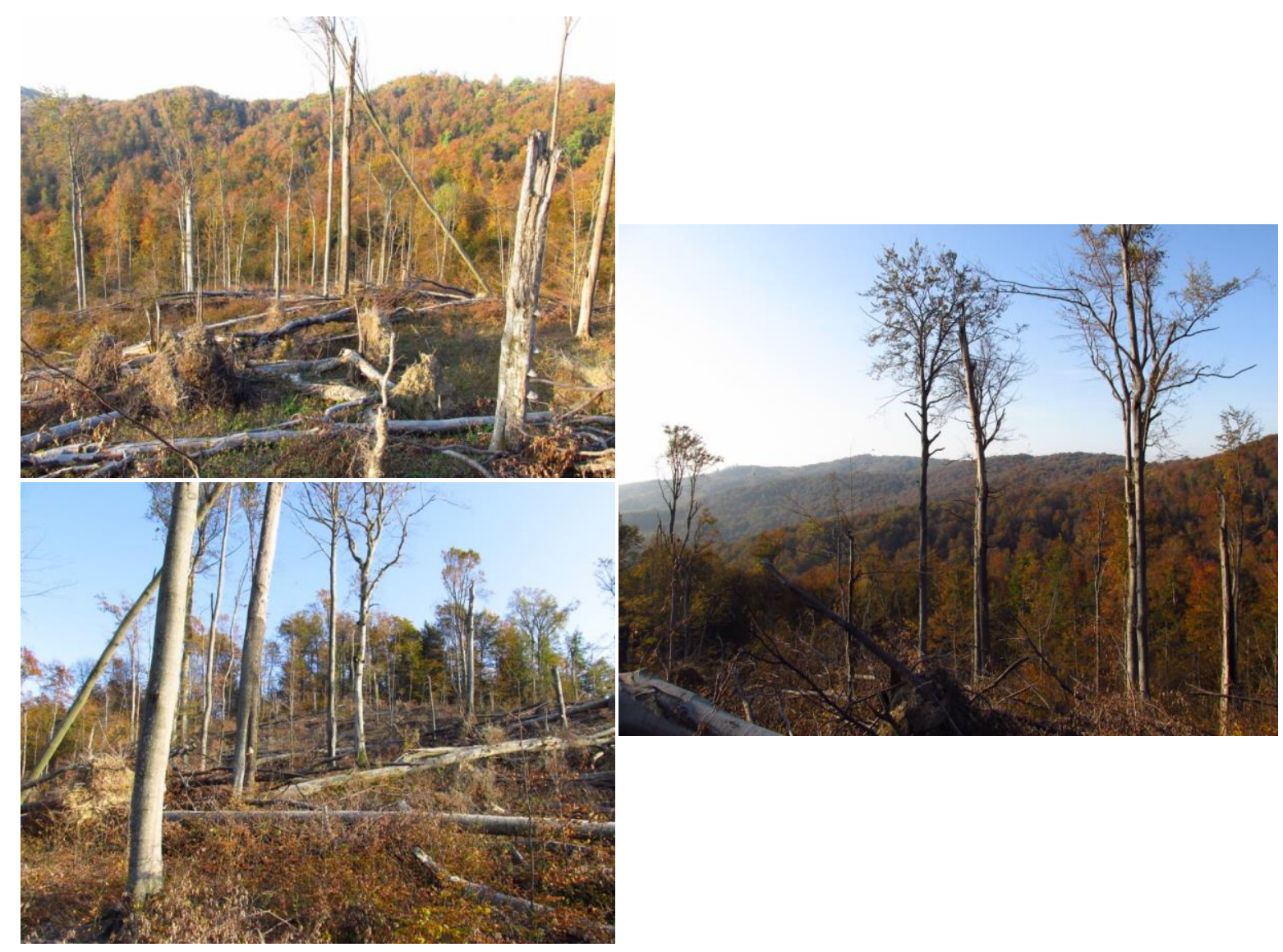

Stefan Kaufmann, Tobias WeinRICH, Markus HaUcK \& Christoph Leuschner Journal of Vegetation Science (accepted). 


\begin{abstract}
Question: Biodiversity surveys of epiphytic bryophytes and lichens on standing trees are mostly restricted to the lowermost $2 \mathrm{~m}$, since sampling above this level is time-consuming and therefore expensive. However, sampling only the stem base is likely to result in underestimation of forest epiphyte diversity, because microclimate and physico-chemical site conditions, both of which vary with height above the ground, play important roles for poikilohydric organisms. We investigate variation in epiphyte diversity and composition along the vertical gradient in forests and discuss factors that may potentially account for height-dependent distribution patterns.
\end{abstract}

Location: Montane primeval beech forest Havešová in the Carpathians, eastern Slovakia.

Methods: Ten circular plots, each $500 \mathrm{~m}^{2}$, were selected randomly in an area severely affected by windfall. Epiphytes were sampled along the stems of recently uprooted trees, from base to the canopy. Mean Ellenberg indicator values (EIV) for light, moisture, acidity and nitrogen availability were used as surrogate variables for environmental interpretation of compositional patterns for sampling segments of $2 \mathrm{~m}$ along the stem.

Results: By sampling only the lowest $2 \mathrm{~m}, 10 \%$ of the total bryophyte and $48 \%$ of the lichen species would have been missed. We detected systematic patterns of compositional variation for both groups along the vertical gradient. While pleurocarpous mosses and liverworts were mostly restricted to the stem base, acrocarpous mosses and crustose lichens occurred along the stem almost to the top. Foliose and fruticose lichens were concentrated at intermediate heights and the upper canopy. Patterns of variation in EIVs suggested that increasing light availability, decreasing moisture and increasing inputs of acidic and nitrous substances are responsible for the compositional shifts along the vertical gradient.

Conclusions: Sampling only the stem base implies severe underestimation of the epiphyte diversity in temperate broad-leaved forests. The middle and the upper parts of tree stems have distinctive compositions of epiphytic cryptogams, because microclimate and physico-chemical site factors vary with elevation above the ground.

Key words: acidity; bryophytes; canopy; Ellenberg indicator values; Fagus sylvatica; lichens; light; moisture; primeval forests; species composition; vertical gradient 


\subsection{Introduction}

Bryophytes and lichens play important roles in forest ecosystems. Not only do they contribute substantially to the total species richness (Ellis 2012; Gradstein 1995; Sipman 1995), they also retain water and nutrients and thereby provide microhabitats for other organisms, including cyanobacteria and invertebrates (Holz \& Gradstein 2005; Cornelissen et al. 2007). In Central Europe, roughly $30-40 \%$ of the bryophyte and lichen flora is assumed to occur mainly in forests (Wirth et al. 2009; Schmidt et al. 2011). Many temperate and boreal forest bryophytes and lichens are epiphytes, just as in tropical forests, where epiphytism is the response to the particularly fierce competition for light and space (Grams \& Lüttge 2010).

In contrast to the ground vegetation and the plant cover of downed wood and boulders, a complete overview of epiphytes of live and dead standing trees within a study area is hampered by accessibility. Studying epiphytes above the tree base is usually time-consuming and can be expensive, if, for example, professional tree-climbers or technical equipment like cranes or towers are hired (e.g. Boch et al. 2013; Lakatos \& Fischer-Pardow 2013). A rugged relief and inaccessibility for other reasons may further impede the application of assistive technologies. For practical reasons, species inventories have therefore often been limited to the lowermost 2 (-3) $\mathrm{m}$ on the stem (Hauck et al. 2002; Friedel et al. 2006). Due to these technical obstacles, few studies have addressed the contribution of vertical variation in species distribution to the overall compositional variability of cryptogamic epiphytes in forests.

Gradients from the tree base to the crown in microclimate, $\mathrm{pH}$, nutrient availability, $\mathrm{CO}_{2}$ concentration and structural characteristics of the substratum strongly influence epiphytic cryptogam species richness and composition (Coxson et al. 1992; Campbell \& Coxson 2001; Ódor \& van Hees 2004; Hauck 2011; Pach \& Podlaski 2015; Leuschner \& Ellenberg 2017). Chemical site conditions vary with height above the ground as the result of differences in exposure to the atmosphere, nutrient inputs from animals, concentration effects along the stemflow path, and vertical gradients in bark texture, which is in turn an important site characteristic itself (Kermit \& Gauslaa 2001). However, knowledge of how these factors influence epiphytic bryophyte and lichen species richness and composition along the vertical gradient is weak.

Vertical gradients in the distribution of vascular epiphytes in the tropics have been addressed in several studies (e.g. Nieder et al. 2000; Krömer et al. 2007), while the vertical distribution of epiphytic bryophytes and lichens on whole trees has rarely been studied. Such studies have, for example, been conducted in temperate rainforests of Tasmania (Jarman \& Kantvilas 1995) and 
the Pacific Northwest of North America (McCune et al. 1997; Sillett \& Rambo 2000), and in tropical rainforests (Goda-Sporn et al. 2010). Studies on vertical gradients in the epiphytic cryptogam vegetation in Europe have so far all concerned managed forests and their focus has primarily been on differences in species richness between the stem base (0-2 $\mathrm{m}$ above the ground) and the rest of the stem (above $2 \mathrm{~m}$ ) (Fritz 2009; Boch et al. 2013; Marmor et al. 2013; Kiebacher et al. 2016). To our knowledge, primeval temperate European forests have so far not been studied with respect to the vertical distribution of cryptogamic epiphytes.

For this reason, we took the unique opportunity to study epiphytic bryophytes and lichens on European beech (Fagus sylvatica L.) trees in a primeval forest of the Carpathians, downed after a major windthrow event. Our aim is to quantify the extent to which total epiphytic bryophyte and lichen species richness is underestimated when only the stem base (defined as the lower 2 $\mathrm{m}$ above the ground) is surveyed rather than the entire tree. Since epiphytic bryophytes in general prefer moister microhabitats than lichens (Lesica et al. 1991), and since moist conditions are preferentially found near the stem base (Ranius et al. 2008; Hauck 2011), we expected that limiting surveys to the stem base would imply considerably greater underestimation of the total species richness for lichens than for bryophytes (hypothesis 1). Since bryophyte species richness is expected to decrease from the tree base to the crown, whereas lichen species richness is assumed to increase in the same direction, we tested the hypothesis (hypothesis 2) that the variation in cryptogam epiphyte species richness and composition is related to vertical gradients in physico-chemical site factors and microclimate. This was accomplished by use of the Ellenberg system of ecological indicator values as proxies for the light climate, temperature, moisture, acidity and nitrogen availability of microsites replacing each other along the tree stems from ground to canopy (Berg 2010; Wirth 2010). The use of this indirect approach was motivated by the fact that direct measurements could not be performed on trees, which were downed at the time the survey took place. Finally, the mean Ellenberg indicator values for consecutive positions along the vertical tree gradient were used to test the specific hypothesis (hypothesis 3) that the composition of epiphytes reflects a complex gradient from darker and moister microclimatic conditions near the stem base to more acid sites with higher nitrogen availability towards and in the crown. 


\subsection{Material and methods}

\section{Study area}

The study was conducted in the western Carpathian Mountains in eastern Slovakia, centraleastern Europe. In the Slovakian and Ukrainian Carpathians, some remnant primeval beech forests have survived the widespread conversion to production forests, and are now on UNESCO's World Heritage List. For our study, we selected the primeval beech forest Havešová in Poloniny National Park (171 ha; $\left.49^{\circ} 00^{\prime} \mathrm{N}, 22^{\circ} 21^{\prime} \mathrm{E}\right)$, which is located near the eastern boundary of the Slovak Republic (Fig. 4.1) and which has not been subjected to forest management activities of any kind for several centuries (Korpel 1995). A heavy storm event caused the uprooting of approximately $90 \%$ of all trees on an area of 8.2 ha in the Havešová forest in May 2014 (see pictures in Figures A4.1 to A4.4.), offering a unique opportunity to study epiphyte species richness and composition along entire stems without tree climbing.

The Havešová forest reserve is located at 550-650 $\mathrm{m}$ a.s.1. in the sub-montane to montane belt on mainly south-facing slopes. Mean annual precipitation and temperature are in the ranges 800-850 mm yr ${ }^{-1}$ and $6.0-6.5^{\circ} \mathrm{C}$, respectively (Vološčuk 2014). The bedrock consists of flysh covered by nutrient-rich soils (Eutric Cambisols; Vološčuk 2014).

The dominant plant community is the Dentario glandulosae-Fagetum after Neuhäusl et al. (1982), a western Carpathian association characterized by the Carpathian endemic Dentaria glandulosa and other eastern European species, including Symphytum cordatum and Isopyrum thalictroides. Fagus sylvatica dominated the tree and shrub layers in which a few individuals of other tree species, notably Acer platanoides and Fraxinus excelsior, also occurred.

\section{Sampling design and analysis of epiphyte diversity}

Field work was carried out during the growing season of 2015. Sampling was restricted to the central part of the windthrow area, excluding a $60 \mathrm{~m}$ wide strip along the reserve border and the outer $15 \mathrm{~m}$ of the windthrow-affected area. The area was mapped using a Garmin Gpsmap 64s GPS unit. A systematic grid with mesh size of $40 \mathrm{~m}$ was established in the sampling area (Fig. 4.1). Each of the 35 points of intersection between grid lines were potential positions for the centre of a circular $500 \mathrm{~m}^{2}$ plot (with 12.6 m radius). Of these 35 , ten (Fig. 4.1) were randomly selected for sampling of epiphytes on trees. In order to be used for sampling, trees had to meet the following four criteria: (1) uprooted during the storm event in 2014; (2) the stem base clearly located within the $500 \mathrm{~m}^{2}$ plot; (3) dbh > $17 \mathrm{~cm}$; and (4) tree height $>24 \mathrm{~m}$. 
Criterion (1) was motivated by our ambition to study the epiphyte vegetation of live trees; older deadwood of advanced decay stages was therefore not considered. Criteria (3) and (4) were motivated by our assumption that the tree had to reach a certain size (height) before a species composition that reflected variation in microclimate and microsite conditions had been fully developed. The mean $\mathrm{dbh}$ and height of the investigated trees were $56 \mathrm{~cm}(17-95 \mathrm{~cm})$ and 24 $\mathrm{m}(12-34 \mathrm{~m})$, respectively.

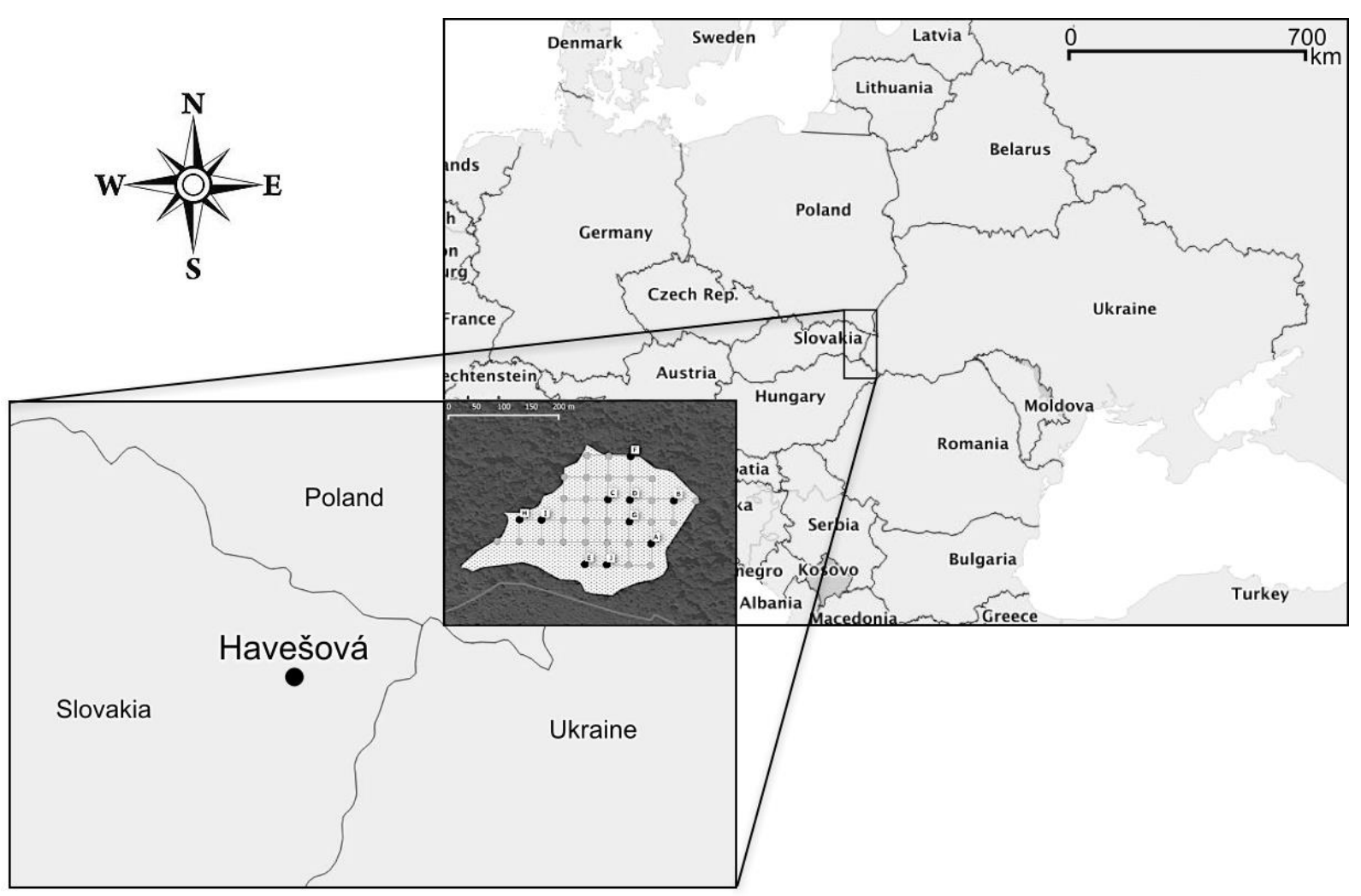

Figure 4.1. Location of the primeval forest Havešová in the Carpathians, Slovakia. The map in the middle shows the extension of the windthrow with the grid (grey vertical and horizontal lines) and the ten randomly selected sampling units (black plots with letters from A-J). The grey line to the south of the windthrow-affected area represents the reserve border. The southernmost plots $(\mathrm{E} \& \mathrm{~J})$ are located at least 60 meters from the reserve border.

Sampling of epiphytes along the stem followed the protocol of Fritz (2009): Each tree trunk was divided into $2 \mathrm{~m}$-segments from the stem base up to the transition between the stem and the crown region of the tree (see Fig. 4.2). The crown with all branches and twigs was divided into the inner and outer crown, characterized by branch (stem) diameter $>10 \mathrm{~cm}$ (IC) and $\leq 10$ $\mathrm{cm}$ (OC), respectively (Fig. 4.2). The 1-13 stem segments and the two crown regions (Table 4.1) on each of the 57 sampled trees formed a total of 572 sampling units in our study.

We recorded presence or absence (P/A) of all detected epiphytic bryophytes and lichens on the accessible surface of each sampling unit. Since most of the fallen trees could not be accessed 
from all sides, some species may have escaped detection and cover estimation for individual species was not feasible and hence not performed.

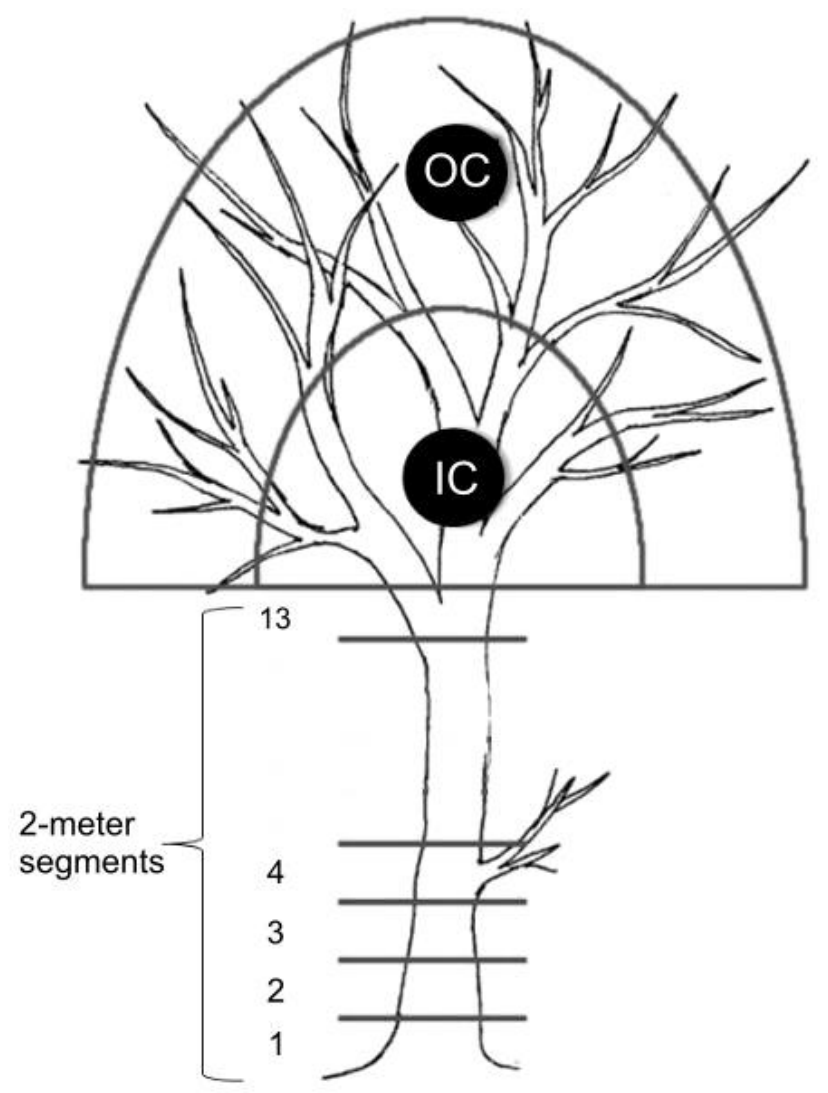

Figure 4.2. Scheme illustrating the sampling design applied for the assessment of epiphytic bryophytes and lichens on beech trees with up to 13 segments of each $2 \mathrm{~m}$ length. IC and OC stand for the inner and outer crown.

Table 4.1. Total number (N) of sampled segments of the height classes S1 to S13 and crown areas (IC, OC) in Havešová forest, and the total number of bryophyte and lichen species found in each segment and crown area.

\begin{tabular}{lccccccccccccccc}
\hline Segment & S1 & S2 & S3 & S4 & S5 & S6 & S7 & S8 & S9 & S10 & S11 & S12 & S13 & IC & OC \\
N & 57 & 55 & 54 & 53 & 51 & 47 & 43 & 38 & 31 & 22 & 13 & 6 & 2 & 50 & 50 \\
Bryophytes & 27 & 18 & 13 & 13 & 13 & 14 & 13 & 12 & 12 & 12 & 8 & 6 & 1 & 13 & 11 \\
Lichens & 35 & 30 & 28 & 37 & 35 & 37 & 27 & 27 & 28 & 24 & 18 & 13 & 8 & 38 & 34 \\
\hline
\end{tabular}

Segments S1 - S13 represent consecutive stem segments of $2 \mathrm{~m}$ length from the stem base (S1) to the top of the tree (maximally to S13). IC (Inner Crown), OC (Outer Crown).

Herbarium specimens were collected for all specimens that could not be identified in the field. Light microscopy was used for the identification of bryophytes and lichens. Three bryophyte samples could only be identified to the genus level (i.e. Ulota sp. and two Zygodon sp.). Thinlayer chromatography (TLC) of lichen thalli was performed according to Orange et al. (2001) 
for all specimens for which qualitative analysis of secondary lichen metabolites and evaluation by use of the LIAS Metabolites Data Base (Elix et al. 2012) could assist species identification. All collected specimens were deposited in the private herbarium of the first author. The nomenclature follows Hill et al. (2006) for mosses, Söderström et al. (2002) for liverworts and Wirth et al. (2013) for lichens. The complete species list including abbreviations is given in Table A4.1.

\section{Inferring site conditions along the vertical gradient using Ellenberg indicator values}

Direct measurements of physico-chemical site factors and microclimate along each vertical tree height gradient could not be made, given that the trees were downed at the time the investigation was carried out. As the best feasible alternative, we instead obtained proxies (surrogates) for microclimate and chemical site variables in each sampling unit by the ecological indicator value methodology, first introduced for vascular plants by Ellenberg $(1974,1992)$ and later applied to bryophytes by Düll (2001) and lichens by Wirth (2001).

The material for this methodology was updated versions of Ellenberg indicator values for bryophytes by Berg (2011; indicator values for $\mathrm{N}$ were not available) based on definitions by Hill et al. (2007) and by Wirth (2010) for lichens. The species-specific indicator values, which are scored on ordinal 9-point scales (1 indicates low, 9 high intensity of the variable in question) for light (L; radiation intensity), moisture availability $(\mathrm{F})$, temperature $(\mathrm{T})$, acidity $(\mathrm{R}$; from low to high $\mathrm{pH}$ ), and nitrogen availability $(\mathrm{N})$, are expert assessments of relative positions of the optima of each species along each environmental gradient (see Table A4.2 for definitions for bryophytes and Table A4.3 for lichens). Ellenberg indictor values for each sampling unit (primary EIV values) for each of L, F, T, R and $\mathrm{N}$ were calculated by calibration as the arithmetic mean of species-specific indicator values for the species recorded as present in each unit. The methodology has several limitations: it is based upon expert judgments and not on empirical data, and using information about the species (indicator values) to obtain variables that, in turn, are used to interpret patterns in species composition implies an element of circular reasoning (e.g. Exner et al. 2002; Zeleny \& Schaffers 2011). Nevertheless, it has been shown in several studies that Ellenberg indicator values accord reasonably well with measured environmental variable values (e.g. Dzwonko 2002; Diekmann 2003). This is also the case for Ellenberg indicator values for moisture $(\mathrm{F})$ and temperature $(\mathrm{T})$, which correspond well with direct measurements of air temperature and relative air humidity along the vertical tree gradient in the Havešová forest (Gottschall et al., unpublished data). 


\section{Statistical analysis}

Due to the small number of sampling units representing segments 12 and 13 (6 and 2, respectively; see Table 4.1), these units were not included in the further analyses. The material that was subjected to analyses therefore consisted of 564 sampling units. All statistical analyses were conducted with R version 3.5.2 (R Development Core Team; 2018).

The effect of height above the ground on the species richness of epiphytic bryophytes and lichens (response variable) was analysed using generalized linear mixed effects models (GLMM) as implemented in the 'lme4' package (Bates et al. 2015). The variable 'tree' (tree number) was included as a random effect and 'segment' (S1-S11, IC and OC) as a fixed effect in the models. In the first analysis, we used 'segment' (with crown regions IC and OC coded as values 12 and 13) as a continuous, semi-quantitative predictor variable. The function 'overdisp_fun' was used to test the response for overdispersion. We detected overdispersion for bryophytes, but no overdispersion was detected for lichens when assuming a Poisson distribution of errors (GLMM with log link function, as generally recommended for count variables). For this reason, we switched to models that assumed a negative binomial distribution of errors. Secondly, we treated the segments and crown regions as a factor variable with 13 levels (S1-S11, IC and OC). Each factor level was compared with all other levels using the Tukey post-hoc test (package 'multcomp') in order to identify eventual zones of sharp change in the response.

Gradients in species composition were identified by parallel use of detrended correspondence analysis (DCA, Hill 1979; Hill \& Gauch 1980) and global multidimensional scaling (GNMDS, Kruskal et al. 1964) (see Appendix S4.1), as implemented in the R package "vegan, version 2.4-3" (Oksanen et al. 2016). All ordination methods may fail to reproduce the real structure of the data, therefore Økland (1996) and van Son and Halvorsen (2014) suggest applying at least two different methods to the same data and comparing the results for congruence.

The data subjected to DCA and GNMDS were not the original set of 564 sampling units, but two subsets: the 'main group' dataset and the 'individual species' dataset. The 'main group' dataset was obtained by first aggregating the species in the sampling units into six groups, i.e. acrocarpous mosses, pleurocarpous mosses, liverworts, crustose lichens, foliose lichens, and fruticose (='shrub') lichens. The number of species recorded in a sampling unit in each group was used as a measure of the abundance of that group in this sampling unit (Figure A4.5). In the next step, we compiled the abundance of each group on each segment (i.e. S1, .., S11, IC and OC) on all trees (6 main groups $\times 13$ composite segments) (Figure A4.6). For the second 
'individual species' dataset, we compiled the occurrence (presence) of each species for each segment $(\mathrm{S} 1, \ldots, \mathrm{S} 11, \mathrm{IC}$ and $\mathrm{OC})$ on all trees $(58$ species $\times 13$ composite segments) (Figure A4.7).

As the GNMDS provided slightly clearer results in both cases according to visual inspection, we used only this analysis for the interpretation of the compositional gradients.

Separate GNMDS ordinations were obtained for the 'main group' dataset and the 'individual species' dataset by use of the function 'monoMDS' in vegan with the following specifications: 100 random starts with each of two- and three-dimensional configurations; maximum number of iterations $=500$; dissimilarity index $=$ Bray-Curtis (as recommended by Faith et al. 1987), rescaling of axes in half-change units, rotation of axes to principal components. Additionally, to reduce the influence of species with high abundances in the ordinations, we conducted a square-root transformation of the raw abundance values of both, the 'main group' and the 'individual species' datasets, as suggested by Kindt \& Coe (2005). Finally, the best twodimensional solutions obtained after comparing the lowest-stress solutions from different starting configurations for each dataset was subjected to further interpretation. EIV values were fitted to the GNMDS ordination plots using the 'envifit' function of 'vegan' to facilitate interpretation of ordination axes. Only variables with $\mathrm{p}<0.1$ were included.

EIV values for light, moisture, temperature, acidity and nitrogen availability were obtained for composite sampling units (S1, S2, .., S11, IC and OC). We calculated simple site mean indicator values, because our basic data set (564 sampling units), from which the 'main group' and the 'individual species' dataset were derived, consists of presence/absence values. Simple site mean indicator values were calculated by averaging the indicator values of the species which occur in each sampling unit ( $\mathrm{N}=564)$. Mean EIV values for the composite sampling units (S1, S2, .., S11, IC and OC) were obtained by averaging the values, first obtained for all sampling units $(\mathrm{N}=564)$, then averaged across trees within each plot and finally across all ten plots.

The non-parametric Kruskal-Wallis test (Kruskal \& Wallis 1952) was used to test for overall differences in mean EIV values between the segments and the crown region. The indicator value for temperature was omitted from further analysis (in GNMDS) as no significant difference was found between the segments (from S1 to S11, including IC and OC). Multiple comparisons were conducted using Dunn`s test (Dunn 1961), when the Kruskal-Wallis test indicated significant differences. 


\subsection{Results}

\section{Characterization of the bryophyte and lichen diversity of the sampled beech trees} In total, 30 bryophyte species (26 mosses, 4 liverworts) and 58 lichen species were found on the 57 trees. Species richness varied between 5 and 36 species per tree, with the number of bryophytes ranging from 0 to 15 species and the number of lichens varying between 2 and 26 species per tree. The most common bryophyte species was Dicranum montanum occurring on $77 \%$ of the sample trees, followed by Hypnum cupressiforme (74\%) and Pterigynandrum filiforme (72\%). The most frequent lichen was Phlyctis argena, which occurred on $98 \%$ of all trees. Other common lichens included Melanohalea elegantula (81 \%), Scoliciosporum umbrinum (77 \%), and Buellia griseovirens (76\%). Thirteen bryophyte species (e.g. Brachythecium rutabulum, Plagiothecium laetum) and lichen species (e.g. Arthonia radiata, Catillaria nigroclavata, Ramalina fastigiata) were found only once. Ten species were found on only two sample trees (e.g. the bryophytes Amblystegium serpens, A. subtile, Orthotrichum striatum and the lichens Physconia detersa, Platismatia glauca, Xanthoria parietina).

\section{Vertical variation in species richness and species distribution along the trees}

The highest total number of bryophytes $(N=27)$ was observed in $\mathrm{S} 1$, while the highest lichen species richness $(N=38)$ was detected in the inner crown (Table 4.1). Both for bryophytes and lichens, the lowest species numbers were detected in the S11 segment, accounting for eight and 18 species, respectively (Table 4.1).

With regard to the variation in epiphyte species richness along the vertical gradient, the first type of models, in which we treated the segments and crown area as continuous variables, indicated a distinct negative effect of increasing height on bryophyte species numbers ( $\mathrm{p}<$ 0.001). In contrast, higher segments appeared to slightly increase lichen species richness, though the effect was not significant $(\mathrm{p}>0.05)$. The comparison of the factor levels used in the second type of models highlighted a significant positive effect of S1 on bryophyte species richness compared to the segments higher up; for lichens, no significant effect was detectable along the entire stem. However, the inner crown had higher lichen species richness than OC and some segments along the stem. The variation in mean bryophyte and lichen species numbers (Fig. 4.3a, b) fully reflected these patterns derived from the second models along the vertical gradient. 


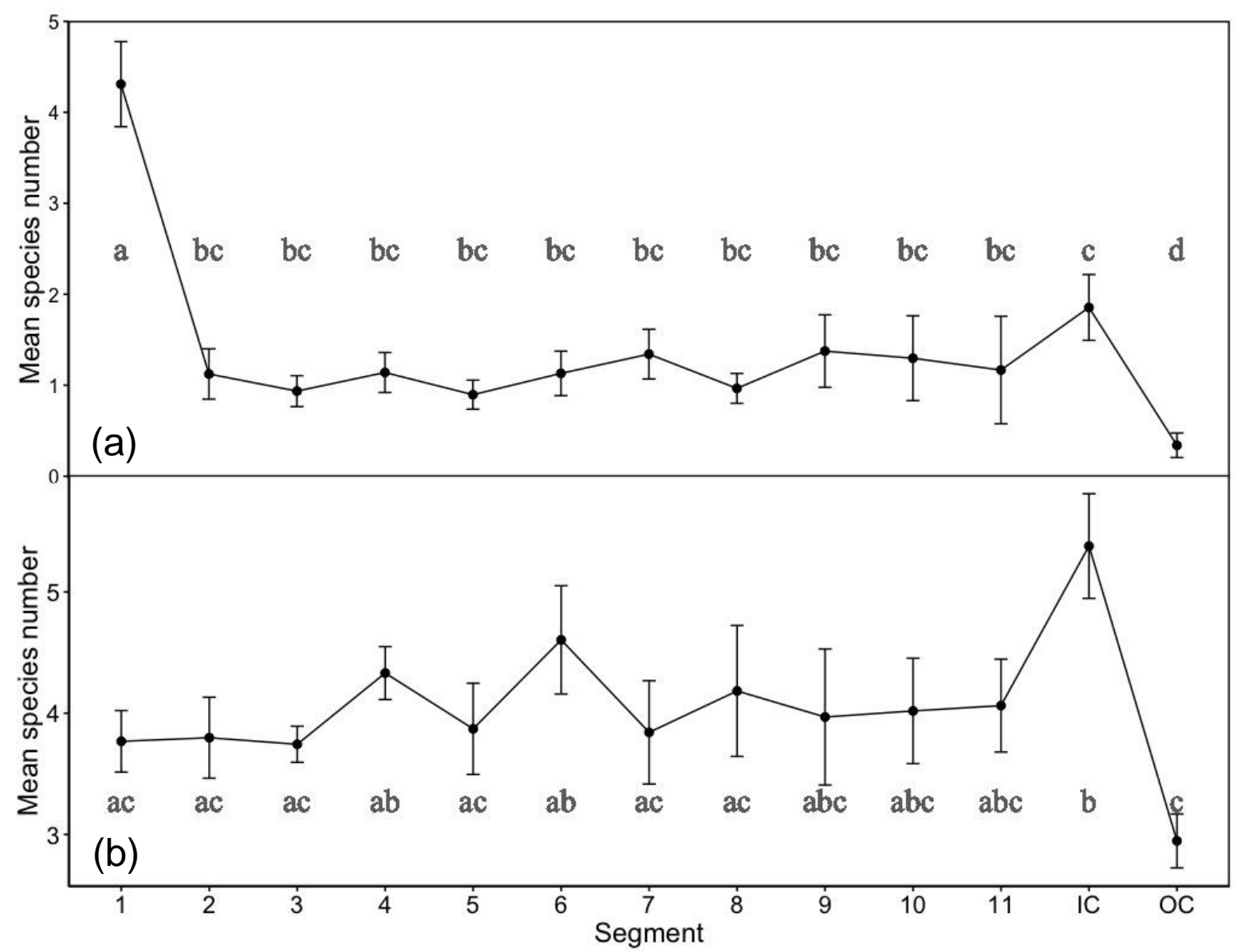

Figure 4.3. Variation of the mean bryophyte (a) and lichen (b) species numbers along the vertical gradient. The letters within (a) and (b) derive from the Tukey test after conducting the second models, in which we treated the segments and crown area as a 13-level factor. Equal letters indicate no significant differences between the segments and the crown area with regard to species richness. Black dots and vertical lines characterize the mean and standard deviation, respectively. S1-S11 indicate each $2 \mathrm{~m}$ segment, IC and OC the inner and outer crown area.

Most of the 71 epiphytic bryophyte and lichen species were found above $2 \mathrm{~m}$ height, whereas 54 species occurred at the stem base. Fifteen species were only found in S1 (0-2 m height), whereas 29 species only occurred above $2 \mathrm{~m}$. The distribution pattern of bryophytes and lichens clearly differed along the vertical gradient. Twenty-seven bryophyte species were found at the stem base at 0-2 m height (S1), whereas 20 species were found above $2 \mathrm{~m}$ height on the stem or on the branches and twigs of the tree crowns. Nine out of 30 bryophytes were restricted to S1, including Amblystegium subtile, Hypnum pallescens, and Isothecium alopecuroides (Figure A4.8). In contrast, only three species were exclusively found above $2 \mathrm{~m}$, i.e. Orthotrichum stramineum, Ulota spp. and Zygodon rupestris. Eighteen species occurred along the entire stem. The number of lichen species observed at the stem base was $48 \%$ lower than the species richness above $2 \mathrm{~m}$ (28 vs. 51 species). Six out of 58 lichen species, such as Arthonia spadicea, Cladonia coniocraea, and Peltigera praetextata, were limited to the stem base while as many 
as 23 lichen species occurred only above $2 \mathrm{~m}$ stem height. This group included Bryoria fuscescens, Catillaria nigroclavata, and Ramalina fastigiata (Figure A4.9). A total of 28 lichen species was found along the entire vertical gradient.

\section{Compositional variation along the vertical gradient}

The two-dimensional GNMDS ordination (stress 0.05 ) of the major bryophyte and lichen groups (i.e. morphological types) separated a group which, according to inference from the EIV values, depended on moister microclimatic conditions and/or lower light intensity from a group associated with lower acidity and/or higher nitrogen availability. Pleurocarpous mosses and liverworts were strongly associated with the stem base, whereas acrocarpous mosses showed a tendency to occur along nearly the entire stem (Fig. 4.4a) and indicated more acid site conditions. Additionally, the stem base turned out to be associated with species typical of moister microclimate and less-acidic microsite conditions as inferred from the ecological indicator values. In contrast, crustose and foliose lichens occurred in intermediate parts of the trees (segments > S2), whereas shrub (fruticose) lichens showed a strong affinity to the crown area. The ecological indicator values suggested that higher nitrogen availability in intermediate segments favoured crustose and foliose lichens.

The two-dimensional GNMDS ordination of individual bryophyte and lichen species (stress = 0.04) (Fig. 4.4b, c) indicated a strong preference of acrocarpous mosses (e.g. Bryum moravicum, Dicranum viride, and Orthotrichum striatum), and a preference of pleurocarpous mosses (e.g. Brachytheciastrum velutinum, Paraleucobryum longifolium, and Pterigynandrum filiforme) and liverworts (e.g. Metzgeria furcata, Radula complanata) for lower segments (< S3). The lichens Cladonia pyxidata, Graphis scripta and Pyrenula nitida showed a tendency to preference for S1, which had a species composition indicative of less acidic, but moister microsite conditions than the upper segments. Most lichen species occurred above the $2 \mathrm{~m}$ level; in the inner crown (Bryoria fuscescens, Massjukiella candelaria and Physcia tenella) or in the outer crown (e.g. Caloplaca cerinella, Hypogymnia tubulosa and Xanthoria parietina) where the species composition indicated higher light (e.g. Massjukiella polycarpa, Parmelia saxatilis, Pseudevernia furfuracea) and nitrogen availability (e.g. Melanelixia elegantula, Pertusaria coccodes, Physconia perisidiosa). Only a few bryophytes were present in higher segments (e.g. Zygodon rupestris and Orthotrichum lyellii). 


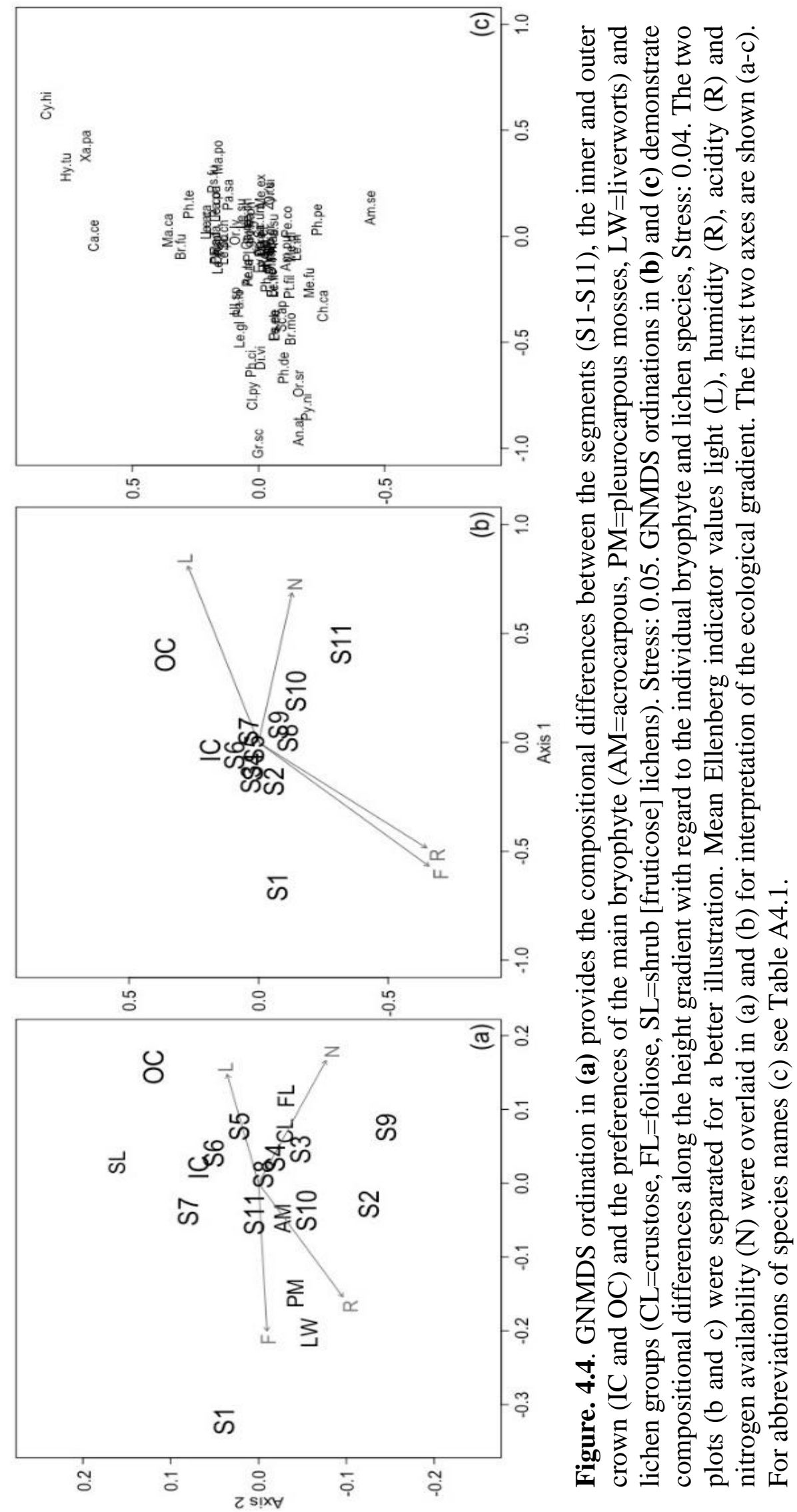




\section{Gradients in environmental conditions}

The Kruskal-Wallis test detected significant differences in the mean Ellenberg indicator values for light, moisture, acidity, and nitrogen availability (Fig. 4.5), but not for temperature (results not shown) along the height gradient. Mean Ellenberg indicator values suggested darker as well as moister, but less acidic and nitrogen-rich, conditions at the stem base than along the rest of the vertical gradient. The mean Ellenberg indicator values of the inner crown did not differ from those of the stem, whereas the Ellenberg indicator values for the outer crown indicated brighter, drier, and more acidic conditions than in the other parts of the tree. The Ellenberg values indicated peak nitrogen availability segments S4, S11 and in the crown while the lowest $\mathrm{N}$ values were observed in S1 and S12-13. However, significant differences in Ellenberg indicator values for light, moisture, acidity and nitrogen were only found between the stem base and the outer crown (and between the stem base and the inner crown for nitrogen).
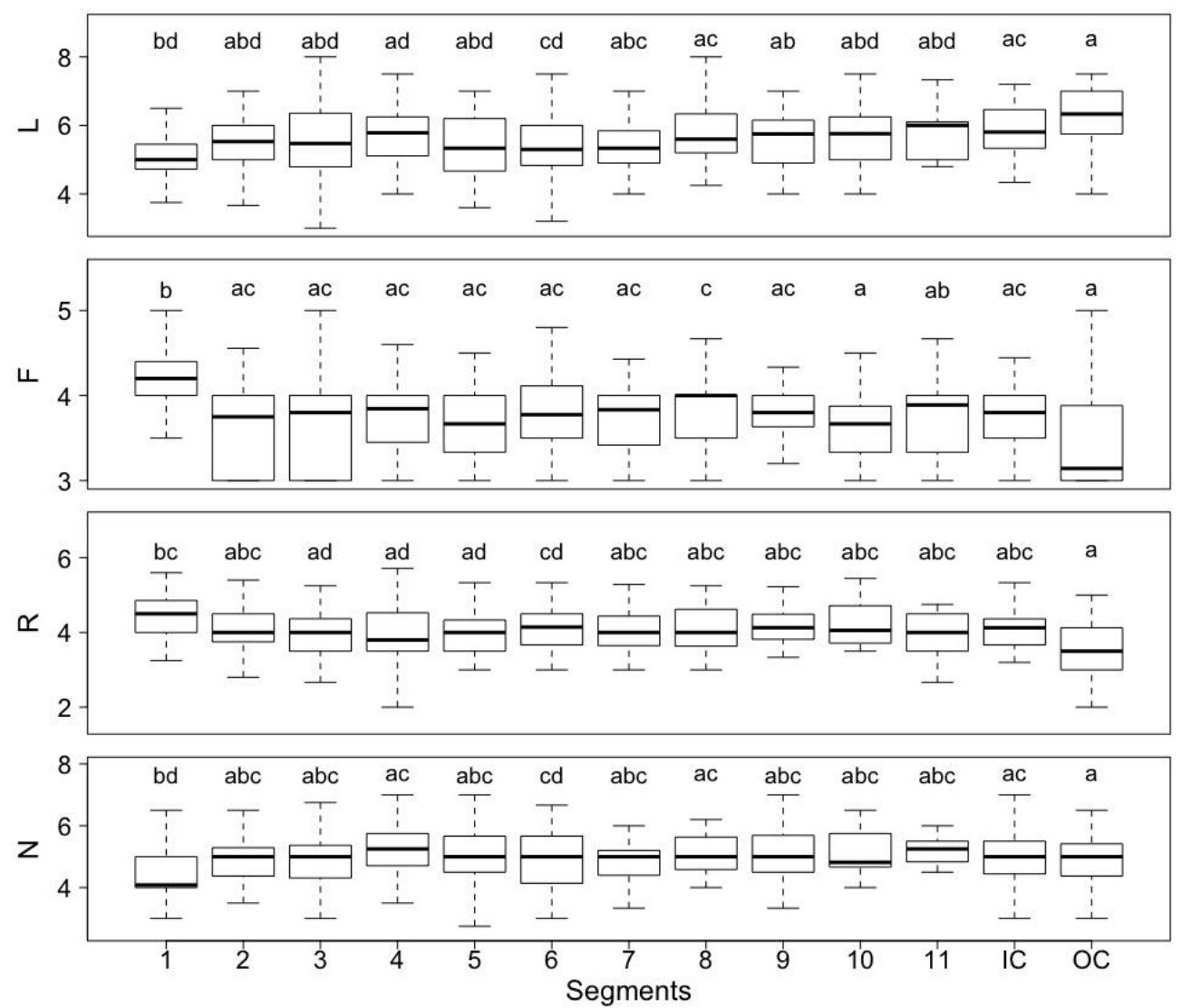

Figure 4.5. Mean Ellenberg indicator values (EIV) light (L), moisture (F), acidity (R) and nitrogen availability (N) for the epiphyte communities in the segments $\mathrm{S} 1$ to S11 and the crown (IC, OC) calculated from the presence of bryophytes and lichens (box plots with arithmetic mean, 25 and 75-percentiles and maxima and minima). Statistics: Kruskal-Wallis test and additional testing with Dunn`s test for multiple comparisons for mean EIVs. Means with equal letters do not differ significantly. Outliers are not shown. 


\subsection{Discussion}

Our study clearly highlights that a considerable number of epiphytes are limited to the tree heights above $2 \mathrm{~m}$. This is the case not only in tropical rainforests, where this question has been frequently addressed (Nieder et al. 2000; Krömer et al. 2007), but also in temperate forests like the primeval forest of European beech investigated here, which was selected for study in order to reduce potential anthropogenic influences. This means that a significant part of the total epiphytic bryophyte and lichen diversity is neglected if only the lowest $2 \mathrm{~m}$ of the tree trunk (i.e. the stem base) is studied, which for practical reasons is typical of biodiversity surveys. In addition, our study indicates that sampling only the stem base will cause a greater underestimation of the total lichen than bryophyte species richness. With this approach, about half ( $48 \%$ in our study) of the lichen species will remain undetected, compared to $10 \%$ of the total bryophyte diversity. This clearly confirms our first hypothesis. It is possible that the differences are in fact even greater, because our study was performed on uprooted trees that were downed in the year before vegetation sampling. Some field observations indicate that the dieback of epiphytes on downed trunks, especially on higher stem segments and in the crown, starts in the first year after tree fall due to environmental changes (Barkman 1958). On the other hand, we did not observe any colonization of the fallen trunks by epiphytes the year after the windthrow. In this context, it should also be mentioned that not only diversity, but also species frequencies may be underestimated when only the stem base is sampled. Kiebacher et al. (2016) state that many red-listed lichen species are crown specialists and a potential overestimation of the extinction risk of these species may be result from excluding the crowns in biodiversity surveys and Red List assessments.

Results comparable to those from our study have been reported by Hale (1952) and McCune et al. (1997) from temperate old-growth forests of North America, where a considerable number of epiphyte species was found only above the stem base. Assessments of the epiphyte diversity along the entire lengths of European forest trees, which were subjected to forest management in the past, also agree with our findings. Our results, supported by previously published studies, thus strongly support the idea that the observed pattern is a general phenomenon independent of the forest type (e.g. broad-leaved vs. coniferous), management history or tree species identity. Studying broad-leaved and coniferous forests in Germany, Boch et al. (2013) found 5 $\%$ of the bryophyte and $28 \%$ of the lichen species exclusively above $2 \mathrm{~m}$ height. In southern boreal coniferous forests of Estonia, as much as two-thirds of the trees' total lichen species would have remained unrecorded if only the lower $2 \mathrm{~m}$ on the stem base had been sampled (Marmor et al. 2012). Surveys of the epiphyte species richness on solitary standing broad- 
leaved trees in the northern Alps (Kiebacher et al. 2016) and coniferous trees in east and southwest Ireland (Coote et al. 2008) also showed similar patterns, even though the studied trees were exposed to environmental conditions along the vertical gradient that deviate from those of the forest interior, thus corroborating the robustness of our conclusion across different ecosystem types and environmental conditions.

The stronger underestimation of total lichen than bryophyte species richness is attributable to the fact that bryophytes tended to be concentrated on the stem base, whereas lichen richness peaks in the canopy, in agreement with our second hypothesis. However, at this point it is important to mention that the observed higher total number of lichen species in the inner crown may result from the larger bark area sampled here, compared to the segments (see definition of the crown area in section 2.2). Nevertheless, our result matches findings from other temperate forests of Europe and North America (Sillett 1995; McCune et al. 1997; Coote et al. 2008; Fritz 2009). This result is attributable to differences in the site preferences of bryophytes and lichens, especially in terms of water supply (Sillett \& Antoine 2004); permanent water saturation of the thallus limits $\mathrm{CO}_{2}$ diffusion to the lichen photobiont, and thus lichen growth, whereas bryophytes are able to grow even under continuously wet conditions (Lange et al. 1996). This may be the most important reason why species richness of the two groups differs along the tree trunks (Bates 1992; Tinya et al. 2009; Hauck 2011; Ódor et al. 2013). Bryophytes may also be more competitive under these conditions, thus further suppressing lichen growth through shading and physical displacement (Ranius et al. 2008). Even lichen-feeding snails may affect lichen distribution along the vertical gradient, as reported by Asplund et al. (2010).

Barkman (1958) and Parker (1995) argued that epiphytes are exposed to microclimatic gradients from the tree base to the top, notably to an increase in light intensity and wind speed and a drier microclimate (higher evaporation). In our study, the composition of the epiphyte vegetation indicated a darker and moister microclimate towards the stem base and an increase in acidity and nitrogen availability towards the crown, thus confirming the views of previous authors as well as our third hypothesis. These spatial gradients in microsite conditions may explain the compositional changes in the bryophyte vegetation observed along the vertical gradient. Thus, pleurocarpous mosses and liverworts, which show strong preferences for the stem base, are replaced as the dominant groups by fewer species of acrocarpous mosses, which tend to occur throughout the entire stem. This is the main reason why total bryophyte species richness decreases towards the crown. A similar pattern in terms of life form change of cryptogams with height on the tree is observed in other forest ecosystems, e.g. in Indonesian rainforests (Goda-Sporn et al. 2010) and in Pseudotsuga-Tsuga old-growth forests of western 
Oregon and Washington State (McCune 1993). The dominance of pleurocarpous mosses and liverworts at the lowest stem segment S1 can be explained by the shady and moist conditions at the stem base in dense forest stands (Lesica et al. 1991; Ranius et al. 2008). Since bryophyte cushions can trap and retain water, they may effectively collect stemflow water at the shaded and cool trunk bases and thus extend the period in which the tissue is hydrated and thus photosynthetically active. Mat- or cushion- forming mosses (e.g. Paraleucobryum longifolium), which dominate the stem bases in our study, are highly productive and thus highly competitive at low light levels (Coote et al. 2008). The sensitivity of these species to desiccation explains why they occur less frequently above the stem base compared to more desiccation-tolerant taxa of the acrocarpous Orthotrichaceae (Bates 2009), including Orthotrichum lyellii and Zygodon rupestris, which are limited to higher stem segments with higher light intensity. In general, European beech tends to have a smooth and thin bark with rather low water-holding capacity and lower cation exchange capacity than tree species with rougher more structured bark. This results in higher stemflow but relatively low bark $\mathrm{pH}$ in beech (Levia \& Germer 2015). However, old beech trees (Fritz et al. 2009), which are abundant in the studied virgin forest, often have a stem base with a thick and strongly fissured bark. These bark traits are generally assumed (albeit rarely proven) to be associated with higher retention of nutrients and higher water-holding capacity (Barkman 1958). Thus, high tree age combined with low deposition of airborne acidifying compounds may explain the lower acidity at the stem base, as indicated by the indicator values. Higher $\mathrm{pH}$ in combination with a moister microclimate may further account for the dominance of bryophytes compared to lichens, as high bark $\mathrm{pH}$ and high moisture availability promote the germination of bryophyte spores (Wiklund \& Rydin 2004).

The morphological types recognised for bryophytes and lichens in our study, differ in their distribution along the vertical gradient. While crustose lichens were almost evenly distributed along the tree, foliose and fruticose lichens dominated the intermediate segments and the crown area, respectively. A similar distribution of functional types was found by McCune (1993) in Pseudotsuga-Tsuga old-growth forests. The preference of foliose and fruticose lichens for upper tree parts is a major reason for increasing lichen species richness with tree height in our study. This finding is attributable to increasing light intensity from the tree base to the top, followed by increase in temperature and decrease of substratum moisture and relative air humidity (Sillett \& Antoine 2004). Sun-exposed microsites often promote epiphytic lichen species richness in forests, as long as humidity does not become a limiting factor (McCune et al. 1997; Fritz et al. 2009; Ódor et al. 2013). The GNMDS ordination shows that crustose 
lichens even occur at lower tree segments, perhaps due to their ability to cope with extreme dry spells and also prolonged wet periods.

At the bryophyte-dominated stem base, some crustose lichens (e.g. Lepraria) can compete by overgrowing bryophytes and colonizing patches of exposed bark between them (Kantvilas \& Minchin 1989). At higher vertical zones, epiphytes rapidly desiccate and become dormant under low humidity and higher temperature (Sillett \& Antoine 2004). However, most foliose and fruticose lichens strongly prefer the upper parts of the trees. These lichens can use the higher photosynthetic quantum flux densities in the canopy under moist conditions and also tolerate extended drought periods due to the scarcity of the more water-demanding bryophytes (Sillett \& Rambo 2000). Nitrophytic foliose lichen species (e.g. Physcia, Xanthoria) benefit not only from the higher solar irradiation in the canopy, but also from the higher inputs of atmospheric nitrogen than at the stem base (van Herk 1999, 2002). The eutrophication tolerance of lichens is largely coupled with high light availability, since this enables the production of sufficient amounts of carbon skeletons for ammonium assimilation and thus detoxification (Hauck \& Wirth 2010).

\section{Conclusion}

We demonstrated that, in the studied primeval beech forest, surveying the diversity of epiphytic bryophytes and lichens exclusively in the lowermost $2 \mathrm{~m}$ results in strong underestimation of total species richness. Comparison with the literature suggests that this result can be generalized across different tree species, forest ecosystems, biomes, and management regimes. The strong underestimation of lichen species richness and moderate underestimation of bryophyte species richness by limiting epiphyte surveys to the stem base for practical reasons results from different ecological preferences of the two groups. Bryophytes generally prefer a moister microclimate, whereas lichen species richness is mostly associated with higher light availability. Our results also corroborate the view that ground-based epiphyte diversity studies do not provide the complete view of a forest's lichen and bryophyte species richness. Therefore, epiphyte diversity surveys should aim at including at least some canopy sampling, whenever possible. Nevertheless, analyses restricted to the lower 2 or $3 \mathrm{~m}$ of the stem are still valuable, as the core of forest species will be recorded. However, the interpretation of these results should always include a discussion about how much of the total species richness might have been missed for individual functional groups by excluding the upper parts of the trees from sampling. 


\section{Acknowledgements}

This study was funded by the Stemmler Foundation, a member of the Stifterverband für die Deutsche Wissenschaft. We are grateful to the Poloniny National Park administration, the Ministry of Defense of the Slovak Republic for the permission to conduct the study, and to the Technical University of Zvolen for field support.

\section{Authors' Contributions}

S.K., M.H. and C.L. conceived the ideas; S.K. and T.W designed methodology; T.W. collected the data; S.K. analysed the data; M.H. and C.L. led the writing of the manuscript. All authors contributed critically to the drafts and gave final approval for publication.

\section{Data Availability}

The species and environmental matrices, which were used to perform the statistical analyses as well as the $\mathrm{R}$ codes will be available at https://datadryad.org upon acceptance of this manuscript. 


\subsection{Appendix}

Table A4.1. Species list including abbreviations for NMDS ordination, the occurrences below and above two meters, the crown area (CA: inner and outer crown) and the rel. frequency (\%) based on the occurrences on the total number of trees $(\mathrm{N}=57)$.

\begin{tabular}{lccccc}
\multicolumn{1}{c}{ Species } & Abbreviation & S2 m & >2 & CA & Rel. Frequen \\
\hline Mosses & & & & & \\
Amblystegium serpens & Am.se & 1 & 1 & 0 & 3.51 \\
Amblystegium subtile & Am.su & 2 & 0 & 0 & 3.51 \\
Anomodon attenuatus & An.at & 2 & 2 & 0 & 7.02 \\
Brachythecium rutabulum & Br.ru & 1 & 0 & 0 & 1.75 \\
Brachytheciastrum velutinum & Br.ve & 7 & 1 & 2 & 21.05 \\
Bryum moravicum & Br.mo & 5 & 3 & 0 & 15.79 \\
Dicranum montanum & Di.mo & 11 & 11 & 18 & 77.19 \\
Dicranum scoparium & Di.sc & 3 & 0 & 0 & 5.26 \\
Dicranum viride & Di.vi & 10 & 1 & 1 & 28.07 \\
Homalia trichomanoides & Ho.tr & 1 & 0 & 0 & 42.11 \\
Hypnum cupressiforme & Hy.cu & 9 & 6 & 22 & 1.75 \\
Hypnum pallescens & Hy.pa & 3 & 0 & 0 & 73.68 \\
Isothecium alopecuroides & Is.al & 14 & 0 & 0 & 5.26 \\
Orthotrichum lyellii & Or.ly & 0 & 20 & 9 & 24.56 \\
Orthotrichum spec. & Or.sp & 3 & 13 & 7 & 3.51 \\
Orthotrichum stramineum & Or.si & 0 & 23 & 11 & 38.6 \\
Orthotrichum striatum & Or.sr & 1 & 1 & 0 & 42.11 \\
Paraleucobryum longifolium & Pa.lo & 9 & 3 & 2 & 28.07 \\
Plagiothecium laetum & Pl.la & 1 & 0 & 0 & 40.35 \\
Platygyrium repens & Pl.re & 3 & 17 & 11 & 3.51 \\
Pseudoleskeella nervosa & Ps.ne & 4 & 1 & 1 & 26.32 \\
Pterigynandrum filiforme & Pt.fil & 18 & 5 & 7 & 1.75 \\
Schistidium apocarpum & Sc.ap & 1 & 1 & 1 & 43.86 \\
Ulota spec. & Ul.sp & 0 & 1 & 0 & 19.3 \\
Zygodon rupestris & Zy.ru & 0 & 12 & 1 & 71.93 \\
Zygodon spec. & Zy.sp & 2 & 0 & 0 & 12.28
\end{tabular}

$\underline{\text { Liverworts }}$

Frullania dilatata

Fr.di

$\begin{array}{lll}5 & 14 & 3\end{array}$

Lophocolea heterophylla

Lo.he

2

1.75

Metzgeria furcata

Me.fu

11

21.05

Radula complanata

Ra.co

6

Lichens

Amandinea punctata

Arthonia radiata

Am.pu

0

Ar.ra

0

Arthonia spadicea

Ar.sp

1

Buellia grisovirens

Bu.gr

3




\begin{tabular}{|c|c|c|c|c|c|}
\hline Species & Abbreviation & $\leq 2 \mathrm{~m}$ & $>2 \mathrm{~m}$ & IC & Rel. Frequen \\
\hline \multicolumn{6}{|l|}{ Lichens } \\
\hline Bryoria fuscescens & Br.fu & 0 & 1 & 0 & 1.75 \\
\hline Caloplaca cerinella & Ca.ce & 0 & 1 & 1 & 1.75 \\
\hline Candelariella reflexa & Ca.re & 0 & 29 & 20 & 59.65 \\
\hline Candelariella xanthostigma & Ca.xa & 2 & 15 & 5 & 33.33 \\
\hline Catillaria nigroclavata & Ca.ni & 0 & 1 & 1 & 1.75 \\
\hline Chrysothrix candelaris & Ch.ca & 0 & 1 & 0 & 1.75 \\
\hline Cladonia coniocraea & Cl.co & 2 & 0 & 0 & 3.51 \\
\hline Cladonia fimbriata & Cl.fi & 1 & 0 & 0 & 1.75 \\
\hline Cladonia pyxidata agg. & Cl.py & 10 & 0 & 1 & 19.3 \\
\hline Cyrtidula hippocastani & Cy.hi & 0 & 7 & 7 & 12.28 \\
\hline Dimerella pineti & Di.pi & 2 & 0 & 0 & 3.51 \\
\hline Evernia prunastri & Ev.pr & 0 & 8 & 1 & 15.79 \\
\hline Graphis scripta & Gr.sc & 18 & 0 & 1 & 33.33 \\
\hline Hypogymnia physodes & Hy.ph & 0 & 36 & 49 & 71.93 \\
\hline Hypogymnia tubulosa & Hy.tu & 0 & 3 & 2 & 5.26 \\
\hline Lecanora argentata & Le.ar & 1 & 22 & 19 & 42.11 \\
\hline Lecanora carpinea & Le.ca & 0 & 1 & 0 & 1.75 \\
\hline Lecanora chlarotera & Le.ch & 0 & 32 & 14 & 57.89 \\
\hline Lecanora conizaeoides & Le.co & 0 & 33 & 51 & 66.67 \\
\hline Lecanora glabrata & Le.gl & 2 & 4 & 1 & 10.53 \\
\hline Lecanora pulicaris & Le.pu & 1 & 19 & 13 & 40.35 \\
\hline Lecanora subrugosa & Le.su & 1 & 7 & 2 & 14.04 \\
\hline Lecidella elaeochroma & Le.el & 1 & 6 & 3 & 14.04 \\
\hline Lepraria eburnea & Le.eb & 2 & 7 & 0 & 17.54 \\
\hline Lepraria finkii & Le.fi & 4 & 10 & 5 & 49.12 \\
\hline Lepraria incana & Le.in & 2 & 20 & 4 & 57.89 \\
\hline Massjukiella candelaria & Ma.ca & 0 & 4 & 2 & 7.02 \\
\hline Massjukiella polycarpa & Ma.po & 0 & 17 & 13 & 29.82 \\
\hline Melanelixia glabratula & Me.gl & 1 & 11 & 3 & 28.07 \\
\hline Melanohalea elegantula & Me.el & 0 & 30 & 22 & 80.7 \\
\hline Melanohalea exasperatula & Me.ex & 0 & 5 & 4 & 8.77 \\
\hline Parmelia saxatilis & Pa.sa & 0 & 9 & 7 & 25.00 \\
\hline Parmelia sulcata & Pa.su & 0 & 4 & 3 & 17.54 \\
\hline Parmelina pastillifera & Pa.pa & 1 & 0 & 1 & 7.02 \\
\hline Peltigera praetextata & Pe.pr & 0 & 4 & 0 & 1.75 \\
\hline Pertusaria coccodes & Pe.co & 0 & 1 & 0 & 7.02 \\
\hline Pertusaria leioplaca & Pe.le & 1 & 2 & 0 & 1.75 \\
\hline Phaeophyscia ciliata & Ph.ci & 1 & 12 & 0 & 5.26 \\
\hline Phaeophyscia orbicularis & Ph.or & 3 & 25 & 1 & 24.56 \\
\hline Phlyctis argena & Ph.ar & 1 & 11 & 23 & 98.25 \\
\hline Physcia adscendens & Ph.ad & 0 & 6 & 2 & 10.53 \\
\hline Physcia tenella & Ph.te & 0 & 20 & 11 & 35.09 \\
\hline
\end{tabular}


Species

Lichens

Physconia detersa

Physconia perisidiosa

Platismatia glauca

Pseudevernia furfuracea

Pseudosagedia aenea

Pyrenula nitida

Ramalina fastigiata

Ropalospora viridis

Scoliciosporum chlorococcum

Scoliciosporum sarothamni

Scoliciosporum umbrinum

Xanthoria parietina

Abbreviation $\leq 2 \mathrm{~m} \quad>2 \mathrm{~m} \quad$ IC Rel. Frequency (\%)

$\begin{array}{ccccc}\text { Ph.de } & 1 & 1 & 0 & 3.51 \\ \text { Ph.pe } & 0 & 3 & 0 & 5.26 \\ \text { Pl.gl } & 0 & 2 & 0 & 3.51 \\ \text { Ps.fu } & 0 & 21 & 18 & 36.84 \\ \text { Ps.ae } & 3 & 0 & 0 & 5.26 \\ \text { Py.ni } & 2 & 2 & 0 & 8.77 \\ \text { Ra.fa } & 0 & 1 & 0 & 1.75 \\ \text { Ra.vi } & 1 & 24 & 12 & 61.4 \\ \text { Sc.ch } & 1 & 19 & 11 & 36.84 \\ \text { Sc.sa } & 1 & 26 & 17 & 52.63 \\ \text { Sc.um } & 1 & 38 & 33 & 77.19 \\ \text { Xa.pa } & 0 & 2 & 1 & 3.51\end{array}$




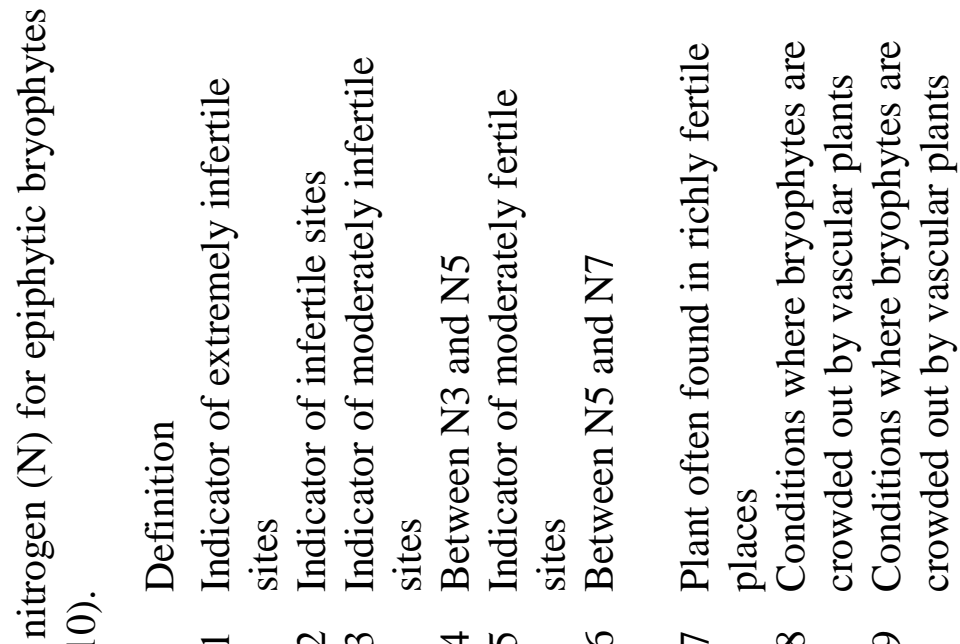

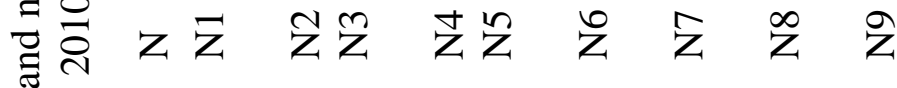

ชิ

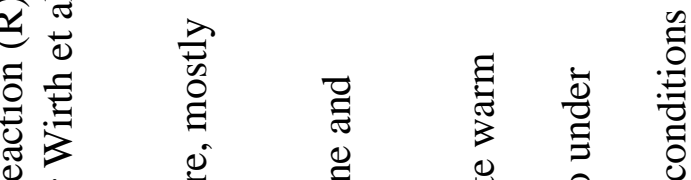

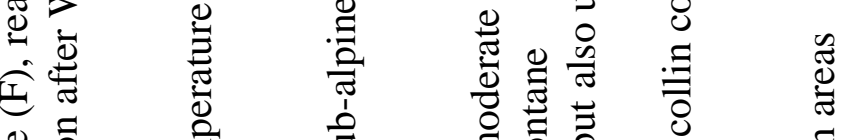

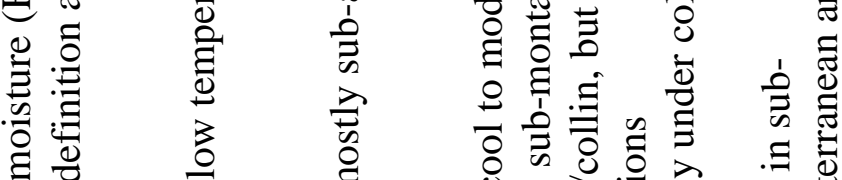

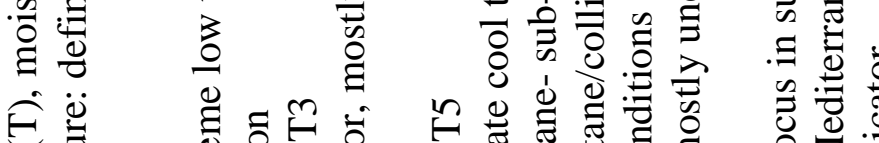

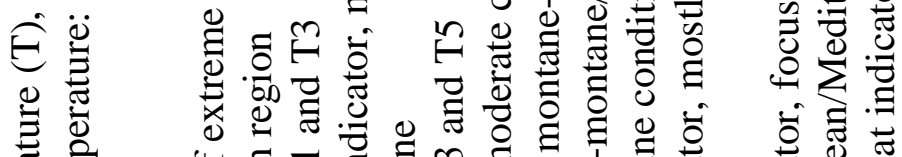

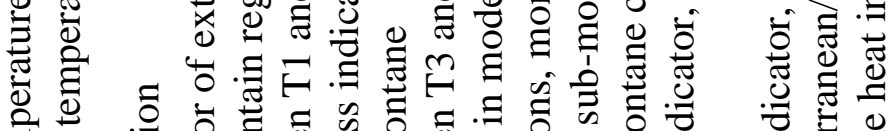

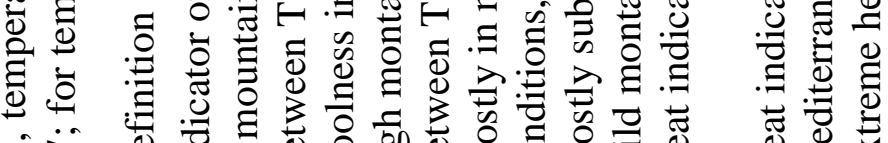

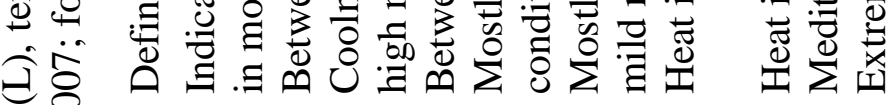

营察

武垔

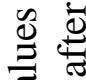

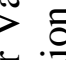

o

过

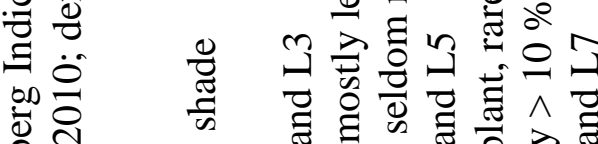

\section{F}

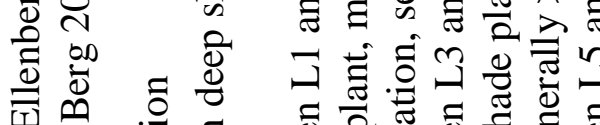

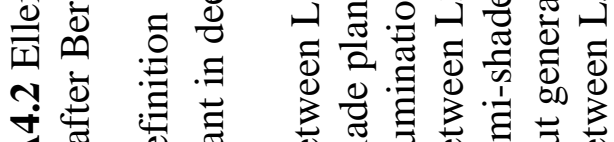

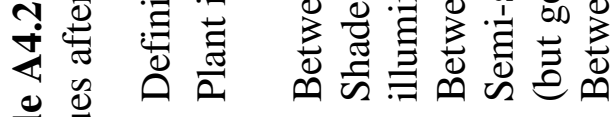

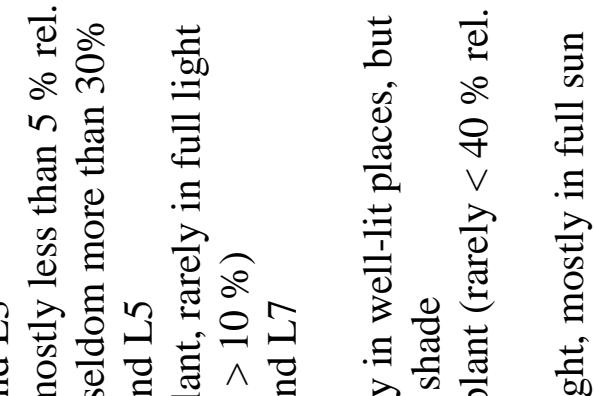

$\frac{0}{2} \frac{\pi}{3}$

츨

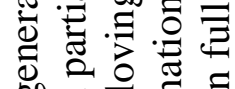

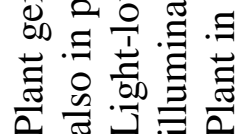

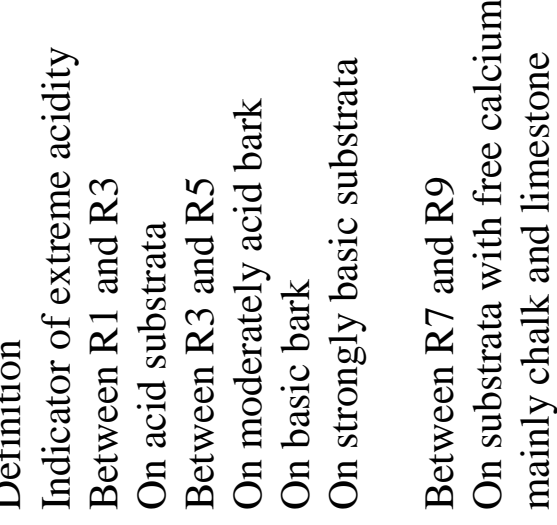

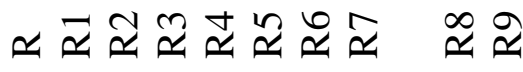

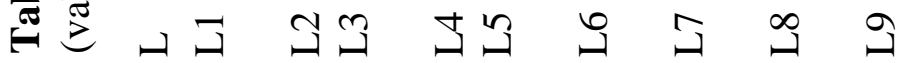

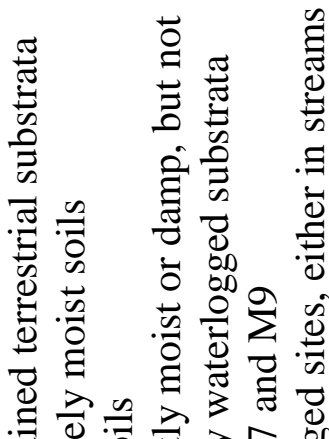

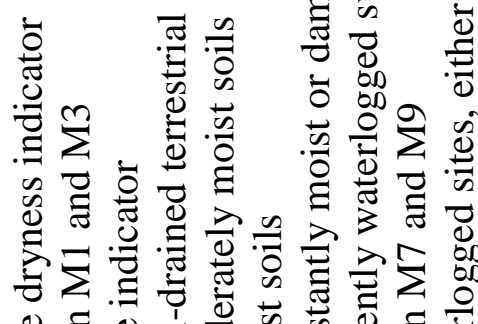

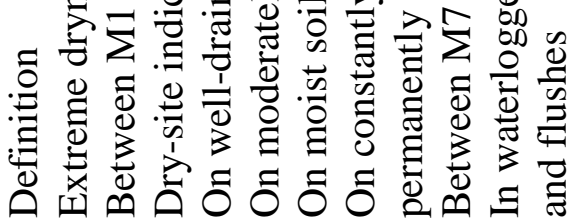

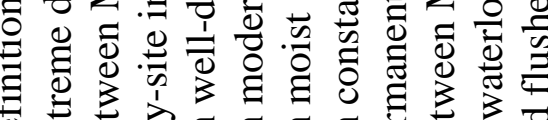
คั

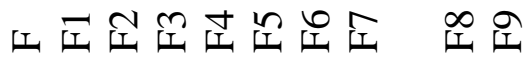




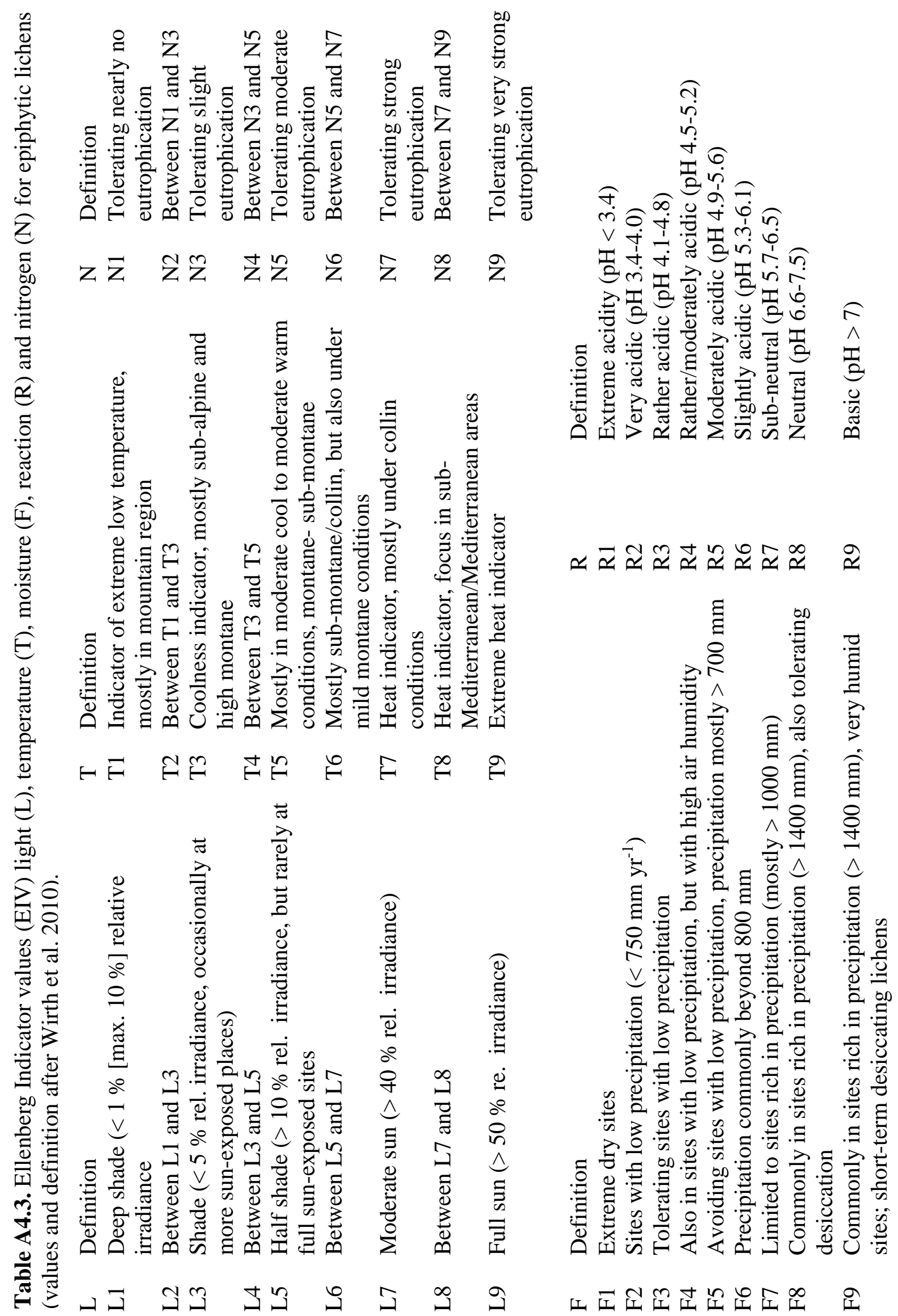


Appendix S4.1. Multivariate analyes

The main compositional gradients were found by parallel use of detrended correspondence analysis (DCA, Hill 1979; Hill \& Gauch 1980) and global multidimensional scaling (GNMDS, Kruskal et al. 1964), because all ordination methods may fail to reproduce the real structure of the data. For this reason, Økland (1996) and van Son and Halvorsen (2014) suggest to apply at least two different methods to the same data and to compare the results for congruence. DCA ordination was conducted with the function 'decorana' in the vegan package with default settings. Procrustes analysis was conducted to find congruence between DCA and GNMDS and function 'protest' was used to estimate the 'significance' of the Procrustes statistic. According to this, ordinations confirmed each other due to a significance at the $\mathrm{p}=0.001$ level (999 permutations) and Procrustes correlation coefficients $r>0.70$. 


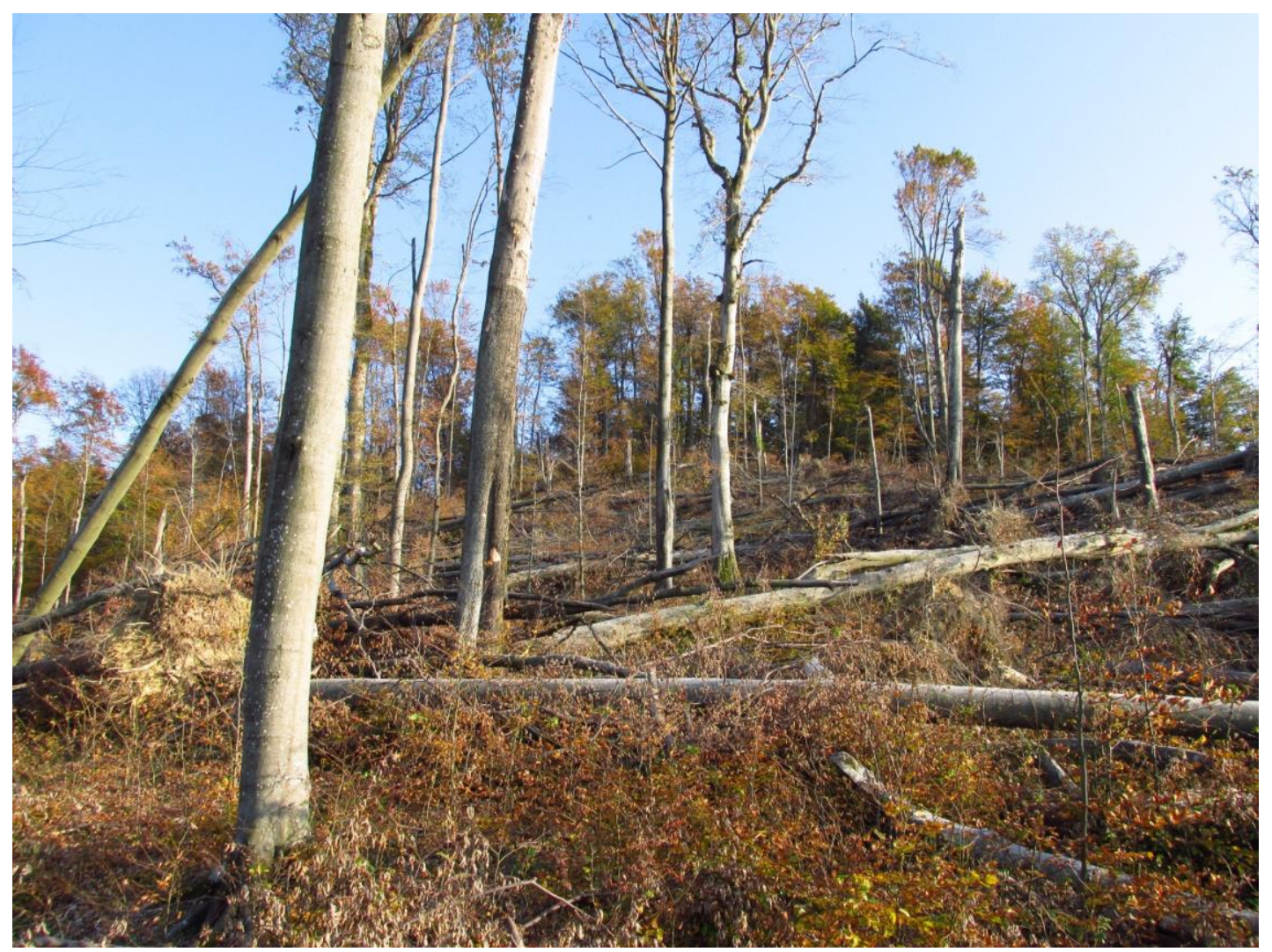

Figure A4.1. Impressions of the windthrow in 2014 in Havešová.

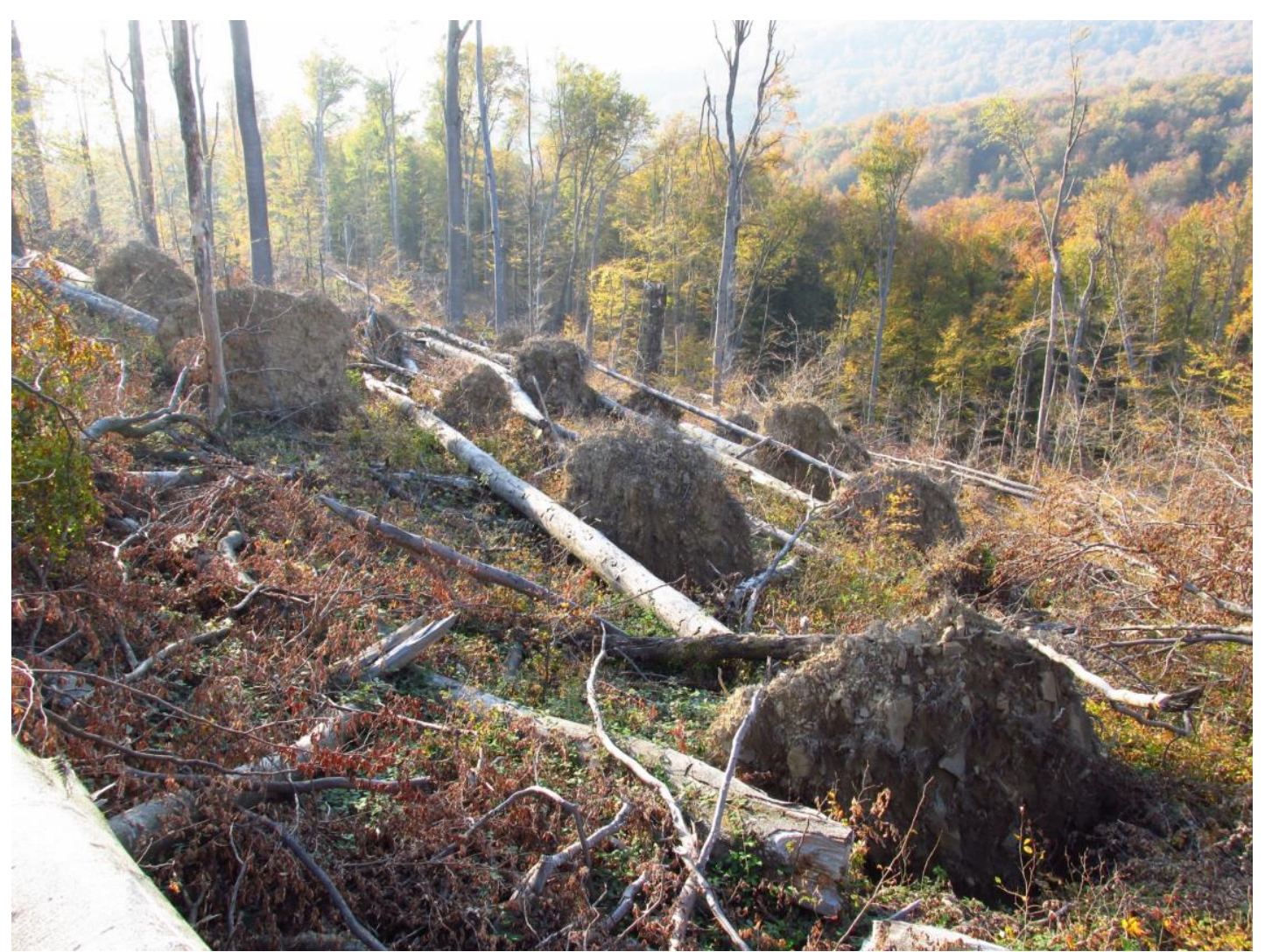

Figure A4.2. Uprooted trees caused by the storm event in 2014. 


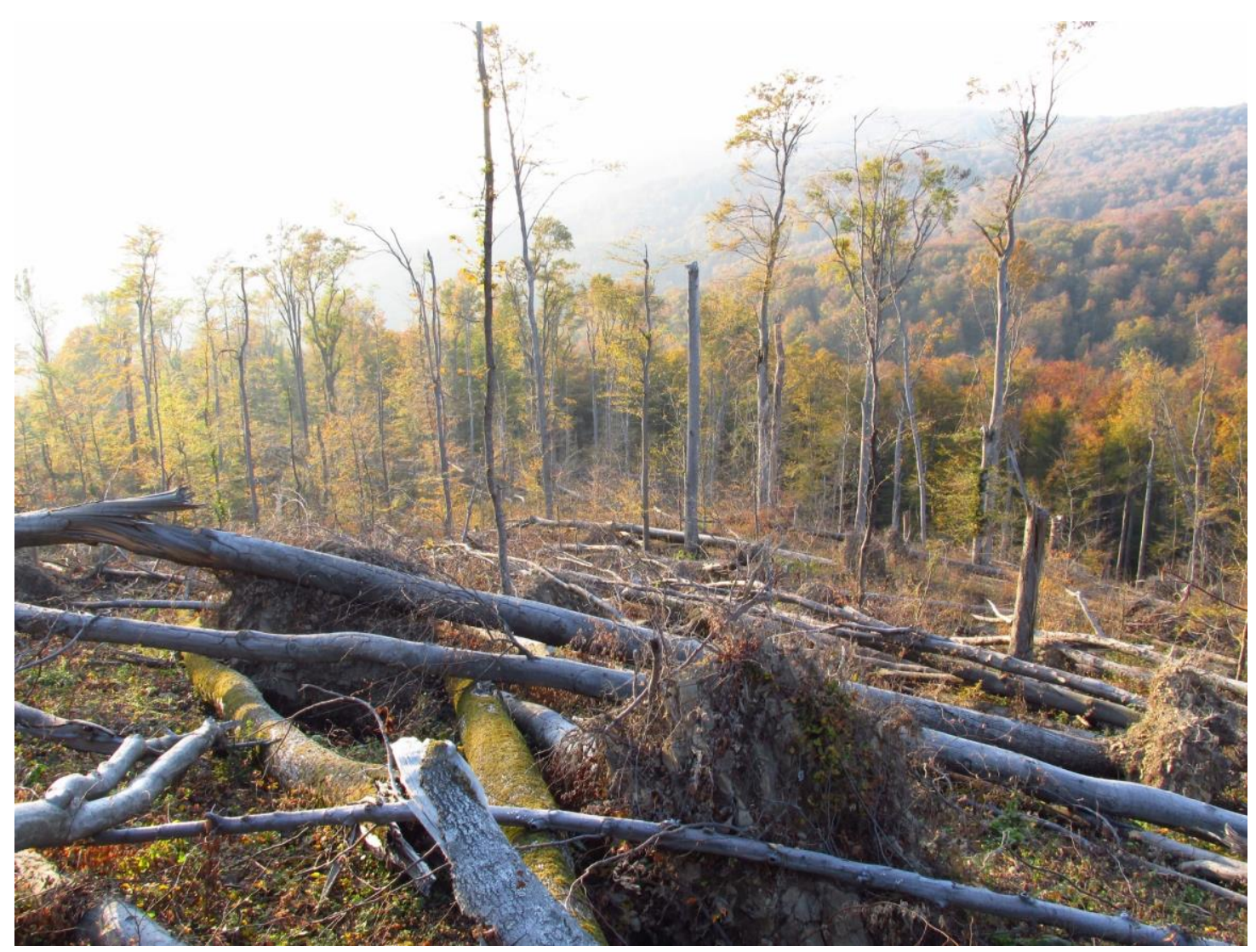

Figure A4.3. One of the plots, where epiphytic cryptogams were detected along the trees.

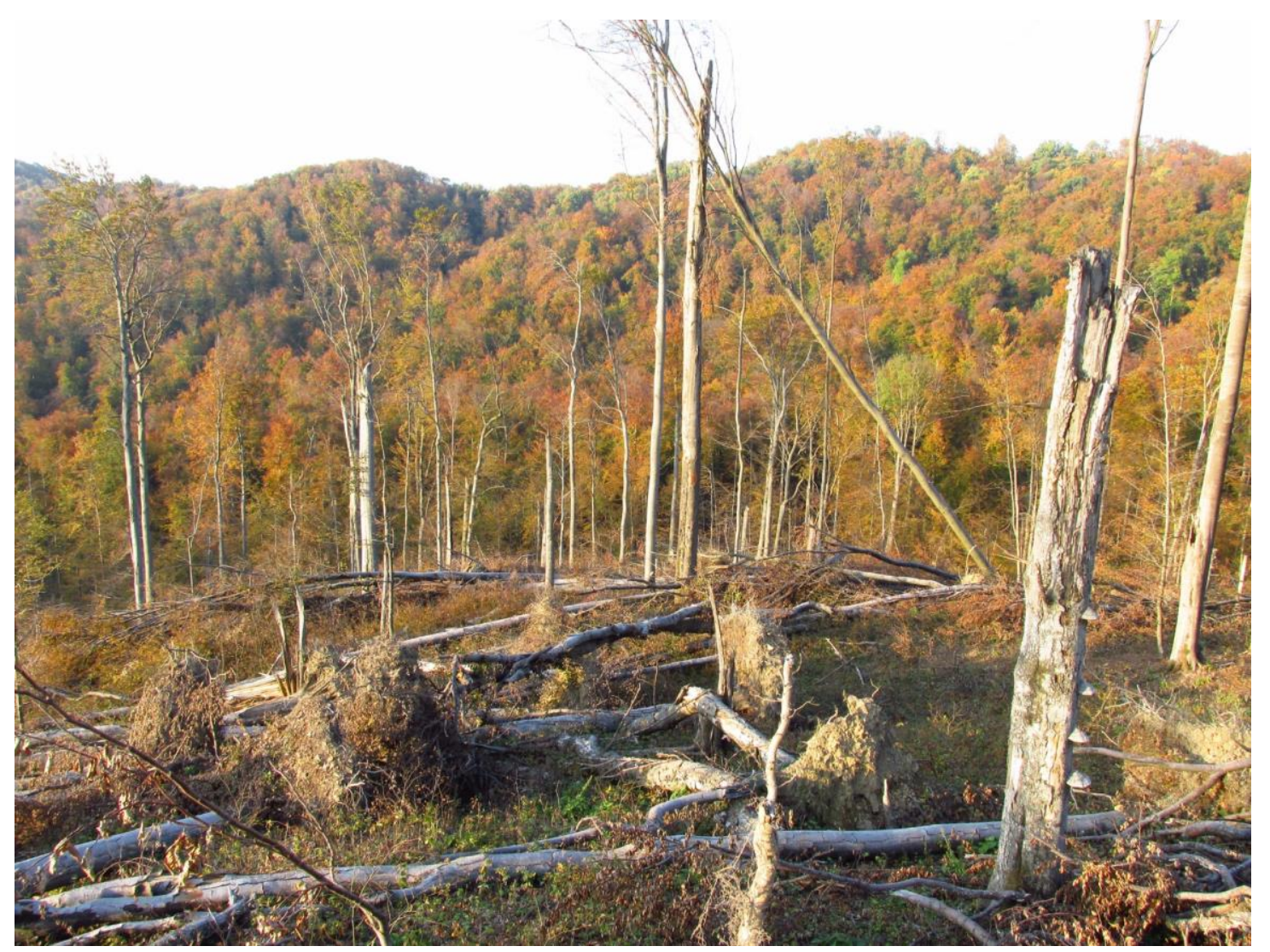

Figure A4.4. Impressions of the windthrow in 2014 in Havešová. A few trees are still standing. 


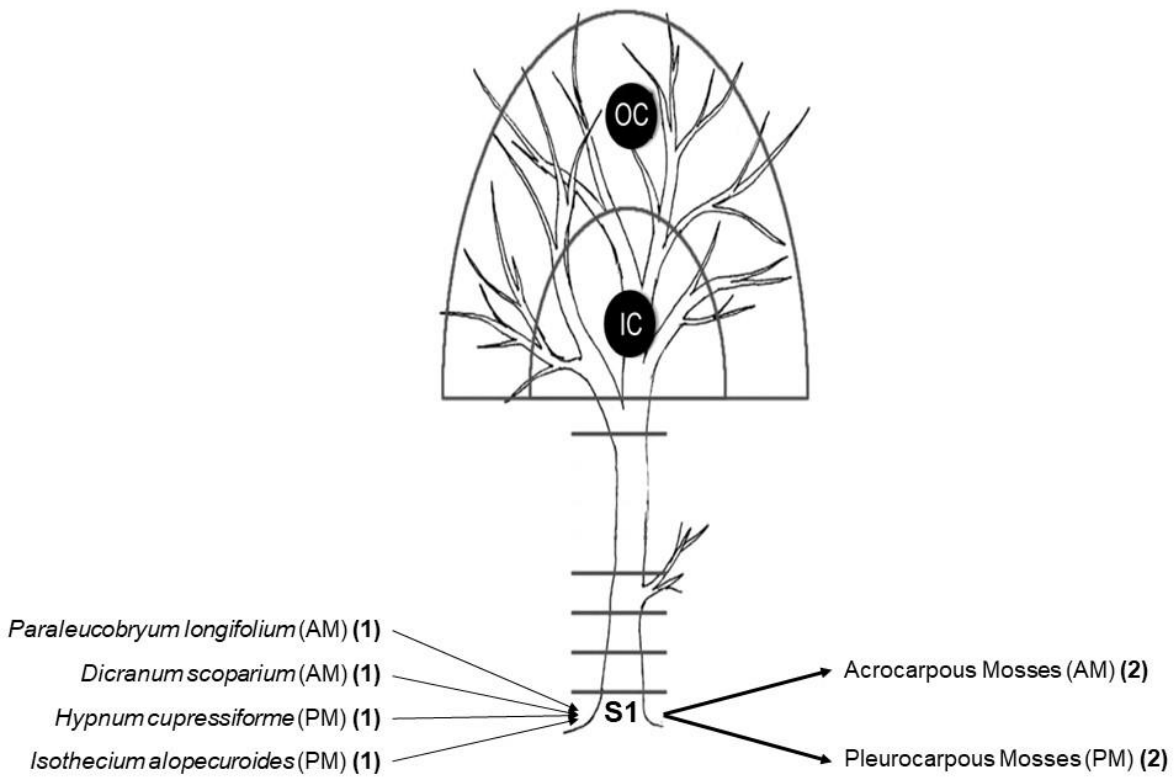

Figure A4.5. Aggregation of individual species to one of the main groups illustrated with acrocarpous (AM) and pleurocarpous mosses (PM). Bold numbers in brackets indicate the presence of the individual species (left side of the tree) and the resulting abundance of the main groups (AM and PM; right side of the tree), respectively. 'S1' characterizes the lowermost segment from 0-2 m, IC and OC the inner and outer crown, respectively. For illustration purpose, only shown for $\mathrm{S} 1$. 


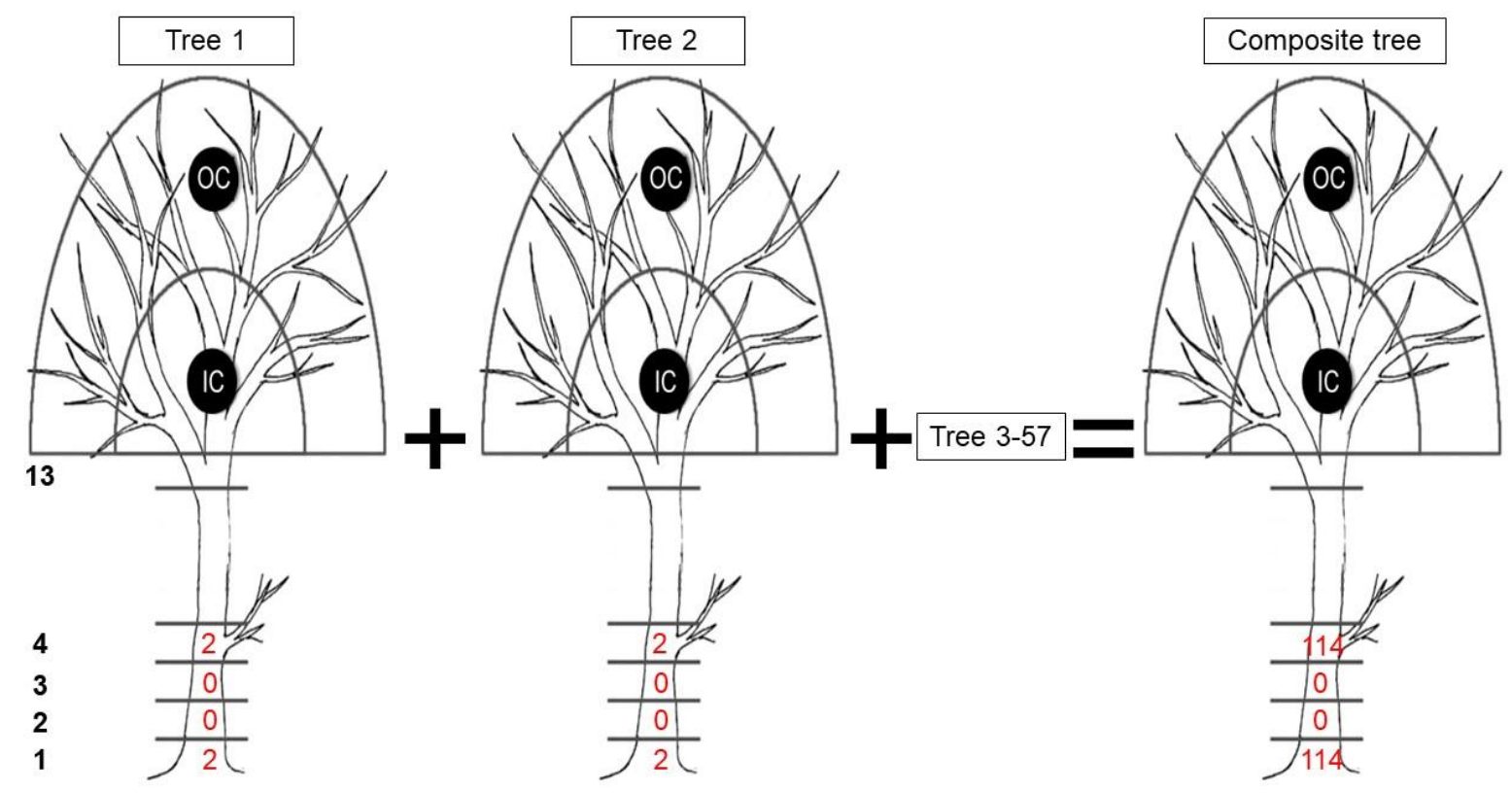

$\mathrm{A}_{\mathrm{OGX}}=\mathrm{T} 1\left(\mathrm{P}_{\mathrm{OgX}}(\mathrm{S} 1, \ldots, \mathrm{S} 13, \mathrm{IC}, \mathrm{OC})\right)+\mathrm{T} 2\left(\mathrm{P}_{\mathrm{OgX}}(\mathrm{S} 1, \ldots, \mathrm{S} 13, \mathrm{IC}, \mathrm{OC})\right)+, \ldots,+\mathrm{T} 57\left(\mathrm{P}_{\mathrm{OGX}}(\mathrm{S} 1, \ldots, \mathrm{S} 13, \mathrm{IC}\right.$,

$\mathrm{OC})$ )

A AGX ... Abundance of group ' $\mathrm{X}$ ' (Composite tree)

T1-T57 ... Total number of sampled trees

$\mathrm{P}_{\mathrm{OGX}}$... Abundance of group ' $\mathrm{X}$ ' in each segment and crown region

S1-S13 ... Each $2 \mathrm{~m}$ segment along the stem

IC, OC ... Inner and outer crown

Figure A4.6. The calculation (formula) of the 'main group' abundances are provided for a better understanding. Bold numbers indicate each $2 \mathrm{~m}$ segment along the stem, IC and OC the inner and outer crown, respectively. Red numbers represent the abundance of the main groups (only shown from S1-S4 for illustration purpose). 


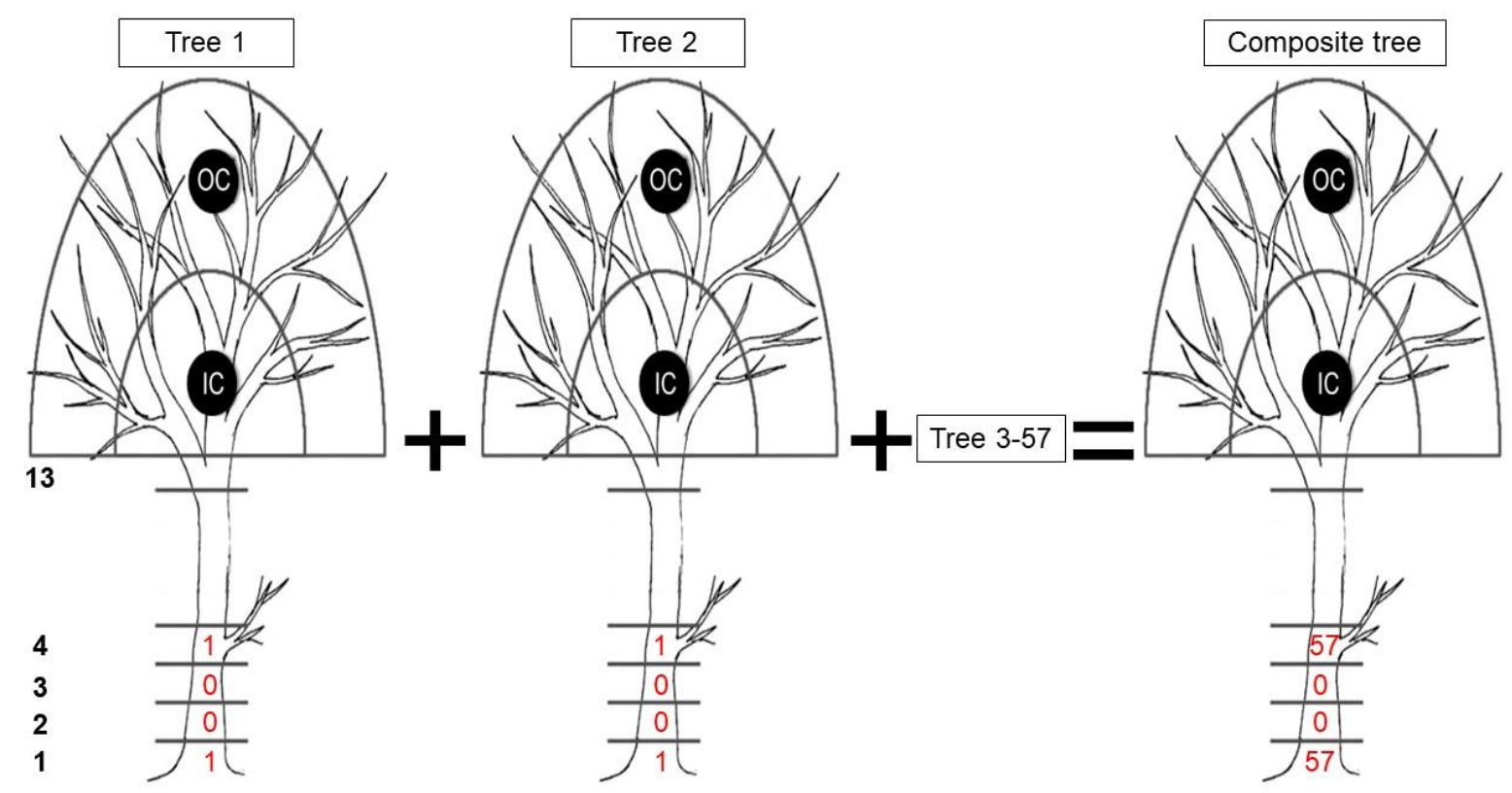

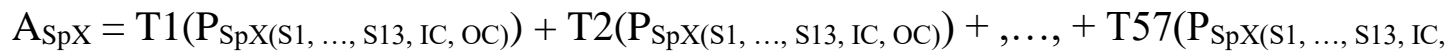
oC)

$\mathrm{A}_{\mathrm{SpX}} \ldots$ Abundance of individual species ' $\mathrm{X}$ ' (Composite tree)

T1-T57 ... Total number of sampled trees

$\mathrm{P}_{\mathrm{SpX}}$... Presence/absence of species ' $\mathrm{X}$ ' in each segment and crown region

$\mathrm{S} 1-\mathrm{S} 13 \ldots$ Each $2 \mathrm{~m}$ segment along the stem

IC, OC ... Inner and outer crown

Figure A4.7. The calculation (formula) of the 'individual species' abundances are provided for a better understanding. Bold numbers indicate each $2 \mathrm{~m}$ segment along the stem, IC and OC the inner and outer crown, respectively. Red numbers represent the presence/absence of the individual species (only shown from S1-S4 for illustration purpose). 


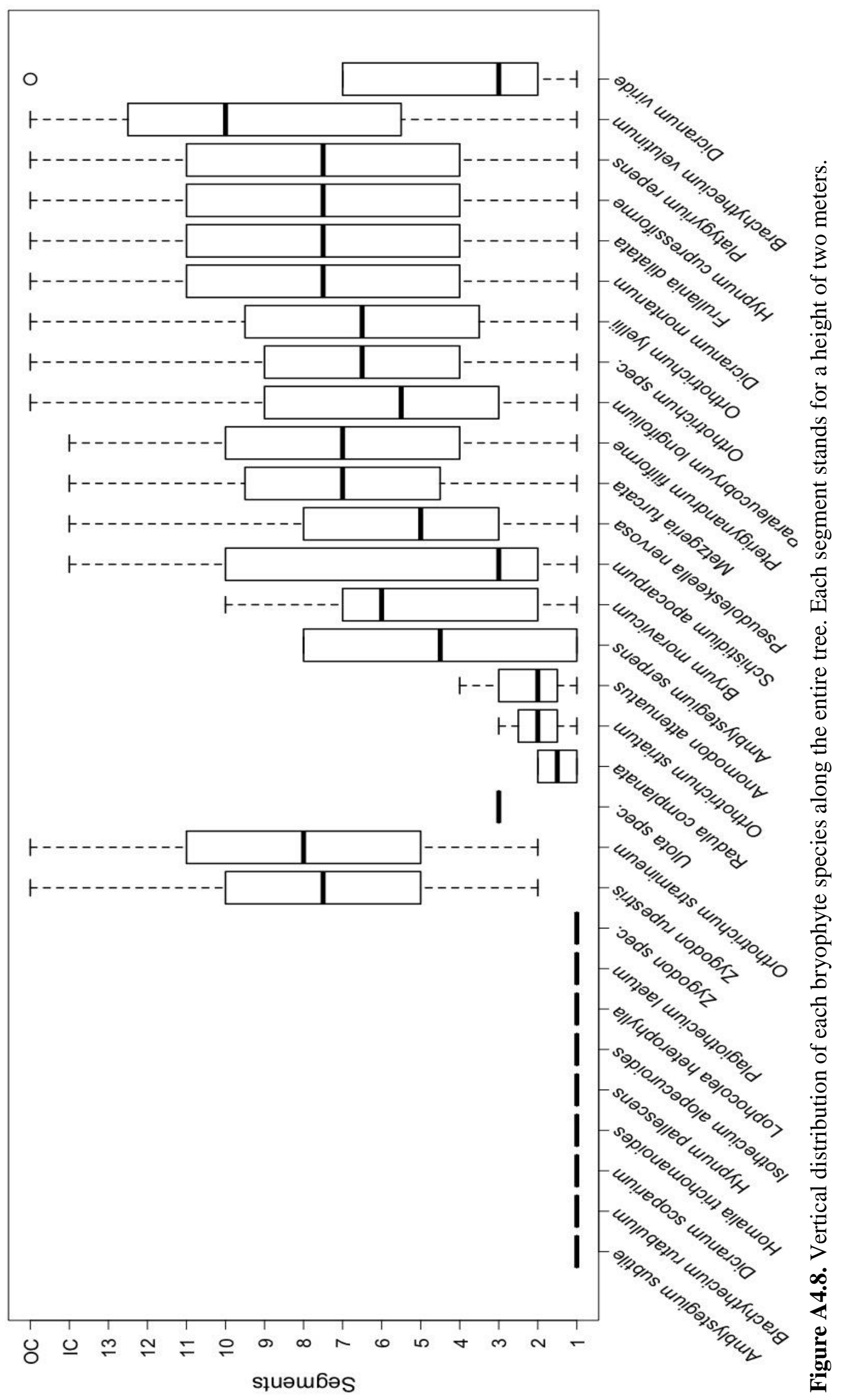




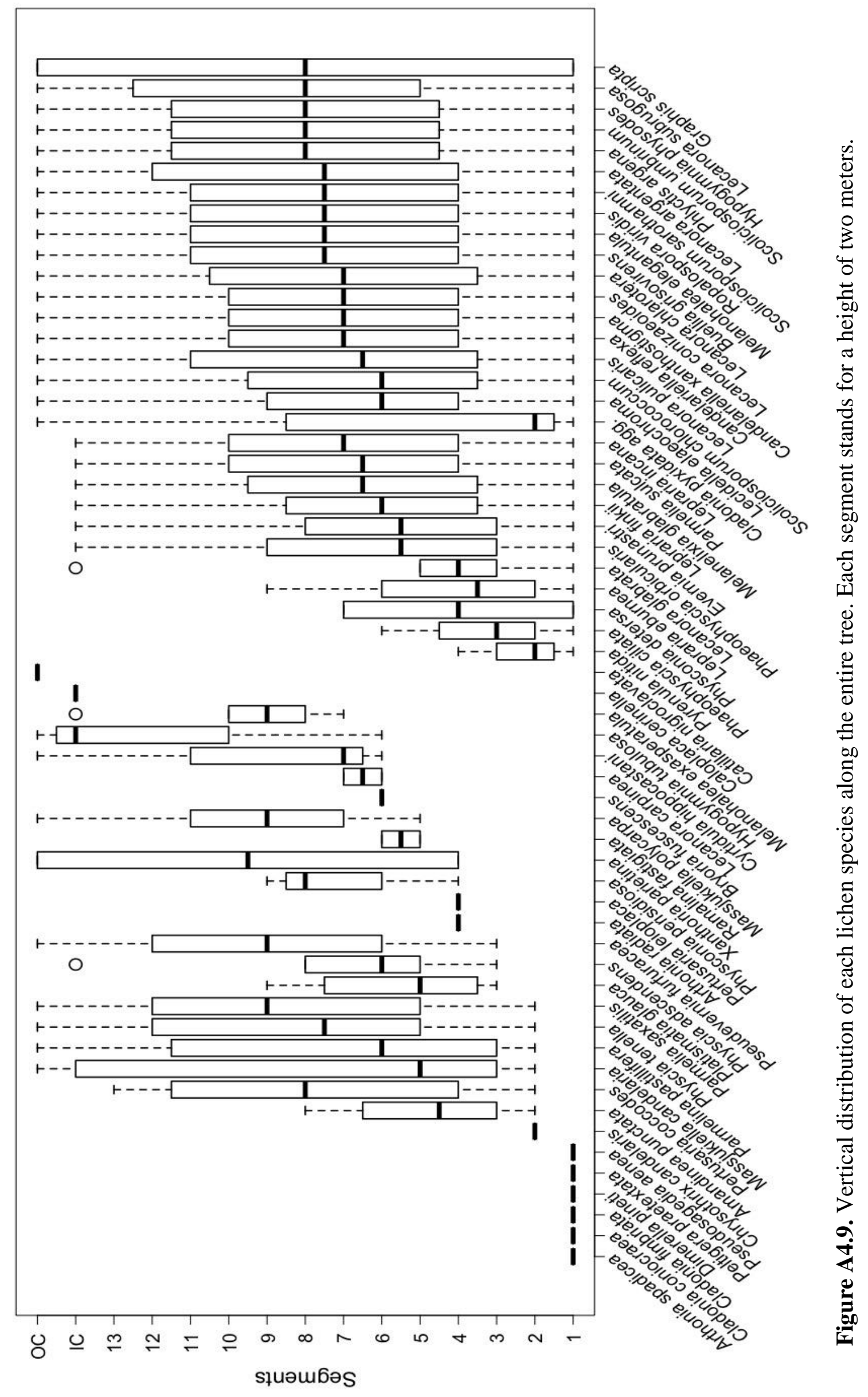




\section{References}

Asplund, J. Larsson, P., Vatne, S., Gauslaa, Y. (2010). Gastropod grazing shapes the vertical distribution of epiphytic lichens in forest canopies. Journal of Ecology, 98,218-225.

Barkman, J.J. (1958). Phytosociology and ecology of cryptogamic epiphytes, including a taxonomic survey and description of their vegetation units in Europe. Van Gorcum \& Comp, Assen.

Bates, J.W. (1992). Influence of chemical and physical factors on Quercus and Fraxinus epiphytes at Loch Sunart, western Scotland: a multivariate analysis. Journal of Ecology, 80, 163-179.

Bates, J.W. (2009). Mineral nutrition and substratum ecology. In: Goffinet, B., Shaw, J.A., (Eds.). Bryophyte Biology $2^{\text {nd }}$ Edition, pp. 299-356. Cambridge University Press, Cambridge.

Bates, D., Maechler, M., Bolker, B., Walker, S. (2015). Fitting Linear Mixed-Effects Models Using lme4. Journal of Statistical Software, 67(1), 1-48.

Berg, C. (2011). EIVs for vascular plants, mosses and lichens. http://www.sci.muni.cz/botany/juice/?idm=10

Boch S., Müller, J., Prati, D., Blaser, S. \& Fischer, M. (2013). Up in the tree - the overlooked richness of bryophytes and lichens in tree crowns. PLoS One.

Campbell, J. \& Coxson, D.S. (2001). Canopy microclimate and arboreal lichen loading in subalpine spruce-fir forest. Canadian Journal of Botany, 79, 537-555.

Coote, L., Smith, G.F., Kelly, D.L., O’Donoghue, S., Dowding, P., Iremonger, S. \& Mitchell, F.J.G. (2008). Epiphytes of Sitka spruce (Picea sitchensis) plantations in Ireland and the effects of open spaces. Biodiversity and Conservation, 16, 4009-4024.

Cornelissen, J.H.C., Lang, S.I., Soudzilvskaia, N.A. \& During, H.J. (2007). Comparative cryptogam ecology: A review of bryophyte and lichen traits that drive biogeochemistry. Annals of Botany, 99, 987-1001.

Coxson, D.S., McIntyre, D.D. \& Vogel, H.J. (1992). Pulse Release of Sugars and Polyols from Canopy Bryophytes in Tropical Montane Rain Forest (Guadeloupe, French West Indies). Biotropica, 24(2), 121-133. 
Davis, L., Bates, J.W., Bell, J.N.B., James, P.W. \& Purvis, O.W. (2007). Diversity and sensitivity to oxides of nitrogen in London. Environmental Pollution, 146, 299-310.

Diekmann, M. (2003). Species indicator values as an important tool in applied plant ecology a review. Basic and Applied Ecology, 4(6), 493-506.

Dunn, O.J. (1961). Multiple comparisons among means. Journal of the American Statistical Association, 56, 54-64.

Düll, R. (1991). Zeigerwerte von Laub- und Lebermoosen. - In: Ellenberg, H., Weber, H.E., Düll, R., Wirth, V., Werner, W., \& Paulissen, D.: Zeigerwerte von Pflanzen in Mitteleuropa. Scripta Geobotanica, 18, 175-214. Göttingen.

Dzwonko, Z. (2002). Assessment of light and soil conditions in ancient and recent woodlands by Ellenberg indicator values: Using Ellenberg indicator values in woodlands. Journal of Applied Ecology, 38, 942-951.

Ellenberg, H. (1974). Zeigerwerte der Gefäßpflanzen Mitteleuropas. 2. Auflage. Scripta Geobotanica.

Ellenberg, H., Weber, H., Düll, R., Wirth, V., Werner, W. \& Paulissen, D. (1991). Zeigerwerte von Pflanzen in Mitteleuropa. Scripta Geobotanica.

Elix, J. A., Kalb K., Rupprecht J. \& Schobert, R. (2012). LIAS metabolites - A Database for the Rapid Identification of Secondary Metabolites of Lichens ed. Rambold, G. liaslight.lias.net/Identification/Navikey/Metabolites/.

Ellis, C.J. (2012). Lichen epiphyte diversity: a species, community and trait-based review. Perspectives in Plant Ecology, Evolution and Systematics, 14, 131-152.

Exner, A., Willner, W. \& Grabherr, G. (2002). Picea abies and Abies alba forests of the Austrian Alps: Numerical classification and ordination. Folia Geobotanica, 37, 383-402.

Faith, D.P., Minchin, P.R. \& Belbin, L. (1987). Compositional dissimilarity as a robust measure of ecological distance. Vegetatio, 69, 57-68.

Friedel, A., Oheimb, G. V., Dengler, J. \& Härdtle, W. (2006). Species diversity and species composition of epiphytic bryophytes and lichens - A comparison of managed and unmanaged beech forests in NE Germany. Feddes Repertorium, 117, 172-185.

Fritz, Ö. (2009). Vertical distribution of epiphytic bryophytes and lichens emphasizes the importance of old beeches in conservation. Biodiversity and Conservation, 18, 289-304. 
Fritz, Ö., Brunet, J. \& Caldiz, M. (2009). Interacting effects of tree characteristics on the occurrence of rare epiphytes in a Swedish beech forest area. The Bryologist, 112, 488505.

Goda-Sporn, S., Bos, M.M., Kessler, M. \& Gradstein, S.R. (2010). Vertical distribution of epiphytic bryophytes in an Indonesian rainforest. Biodiversity and Conservation, 19, 745760.

Gradstein, S.R. (1995). Diversity of Hepaticae and Anthocerotae in montane forests of the Tropical Andes. In: Churchill, S.P., Balslev, H., Forero, E. and Luteyn, J.L. (eds), Biodiversity and Conservation of Neotropical Monate Forests. New York Botanical Garden, New York, pp. 321-334.

Grams T. E. E. \& Lüttge U. (2010). Space as a Resource. In U. Lüttge, W. Beyschlag, B. Büdel, D. Francis (Eds) Progress in Botany (Genetics - Physiology - Systematics - Ecology), Vol 72. Springer, Berlin, Heidelberg

Hale, M.E. (1952). Vertical distribution of cryptogams in a virgin forest in Wisconsin. Ecology, 33, 398-406.

Hauck, M., Hesse, V. \& Runge, M. (2002). Correlations between the Mn/Ca ratio in stemflow and epiphytic lichen abundance in a dieback-affected spruce forest of the Harz Mountains, Germany. Flora, 197, 361-369.

Hauck, M. (2011). Site factors controlling epiphytic lichen abundance in northern coniferous forests. Flora, 206, 81-90.

Hill, M. O. (1979). DECORANA - A Fortran program for detrended correspondence analysis and reciprocal averaging. Ecology and Systematics, Cornell University, Ithaca, New York, USA

Hill, M. O., \& Gauch, Jr. H. G. (1980). Detrended correspondence analysis: an improved ordination technique. Vegetatio, 42 (1-3), 47-58.

Hill, M.O., Bell, N., Bruggeman-Nannenga, M.A., Brugeś M., Cano, M.J., Enroth, J., Flatberg, K.I., Frahm, J.-P., Gallego, M.T., Garilleti, R., Guerra, J., Hedena, L., Holyoak, D.T., Hyvönen, J., Ignatov, M.S., Lara, F., Mazimpaka, V., Munoz, J. \& Söderström, L. (2006). An annotated checklist of the mosses of Europe and Macaronesia. Journal of Bryology, 28, 198-267.

Hill, M.O., Preston, C.D., Bosanquet, S.D.S. \& Roy, D.B. (2007). BRYOATT - Attributes of British and Irish mosses, liverworts and hornworts. The Saxon Print Group, Norwich. 
Holz, I. \& Gradstein, S.R. (2005). Cryptogamic epiphytes in primary and recovering upper montane oak forests of Costa Rica - species richness, community composition and ecology. Plant Ecology, 178, 89-109.

Jarman, S.J. \& Kantvilas, G. (1995). Epiphytes on an old Huon pine tree (Lagarostrobos franklinii) in Tasmanian rainforest. New Zealand Journal of Botany, 33, 65-78.

Kantvilas, G. \& Minchin, P.R. (1989). An analysis of epiphytic lichen communities in Tasmanian cool temperate rain forests. Vegetatio, 84, 99-112.

Kermit, T. \& Gauslaa, Y. (2001). The vertical gradient of bark pH of twigs and macrolichens in Picea abies canopy not affected by acid rain. Lichenologist, 33, 353-359.

Kiebacher, T., Keller, C., Scheidegger, C \& Bergamini, A. (2016). Hidden crown jewels: the role of tree crowns for bryophyte and lichen species richness in sycamore maple wooded pastures. Biodiversity and Conservation, 25, 1605-1624.

Kindt, R \& Coe, R. (2005). Analysis of differences in species composition. In: Kindt, R \& Coe, R. (eds). Tree diversity analysis - A manual and software for common statistical methods for ecological and biodiversity studies, pp. 123-139. World Agroforestry Centre (ICRAF), Nairobi.

Korpel, S. (1995). Die Urwälder der Westkarpathen. Fischer Verlag, Stuttgart.

Krömer, T., Kessler, M. \& Gradstein, S.R. (2007). Vertical stratification of vascular epiphytes in submontane and montane forest of the Bolivian Andes: the importance of the understorey. Plant Ecology, 189, 261-278.

Kruskal, W.H. \& Wallis, W.A. (1952). Use of ranks in one-criterion variance analysis. Journal of the American Statistical Association, 113(524), 583-621.

Kruskal, J. B. (1964). Multidimensional scaling by optimizing goodness of fit to a nonmetric hypothesis. Psychometrika, 29, 1-27.

Lakatos, M. \& Fischer-Pardow, A. (2013). Nonvascular epiphytes: Functions and risks at the tree canopy. In: Lowman, M., Devy, S., \& Ganesh, T. (Eds.). Treetops at Risk: Challenges of Global Canopy Ecology and Conservation, pp. 223-236. Springer New York, New York, NY.

Lange, O.L., Green, T.G.A., Reichenberger, H. \& Meyer, A. (1996). Photosynthetic depression at high thallus water contents in lichens: concurrent use of gas exchange and fluorescence 
techniques with a cyanobacterial and a green algal Peltigera species. Plant Biology, 109, 43-50.

Lesica, P., McCune, B., Cooper, S.V. \& Hong, W.S. (1991). Differences in lichen and bryophyte communities between old-growth and managed second-growth forests in the Swan Valley, Montana. Canadian Journal of Botany, 69, 1745-1755.

Leuschner, C \& Ellenberg, H. (2017). Ecology of Central European Forests. Vegetation Ecology of Central Europe, vol. I. Springer Nature, Cham.

Levia, D.F. \& Germer, S. (2015). A review of stemflow generation dynamics and stemflow environment interactions in forests and shrublands. Reviews of Geophysics, 53, 673-714.

Marmor, L., Tõrra, T., Saag, L., Leppik, E. \& Randlane, T. (2013). Lichens on Picea abies and Pinus sylvestris - from the tree bottom to the top. Lichenologist, 45, 51-63.

McCune, B. (1993). Gradients of epiphyte biomass in three Pseudotsuga-Tsuga forests of different ages in western Oregon and Washington. The Bryologist, 96, 405-411.

McCune, B., Amsberry, K.A., Camacho, F.J., Clery, S., Cole, C., Emerson, C., Felder, G., French, P., Greene, D., Harris, R., Hutten, M., Larson, B., Lesko, M., Majors, S., Markwell, T., Parker, G.G., Pendergrass, K., Peterson, E.B., Peterson, E. T., Platt, J., Proctor, J., Rambo, T., Rosso, A., Shaw, D., Turner, R. \& Widmer, M. (1997). Vertical Profile of Epiphytes in a Pacific Northwest Old-growth Forest. Northwest Science, 71, 145-152.

Morecrofta, M.D., Taylora, M.E. \& Oliverb, H.R. (1998). Air and soil microclimates of deciduous woodland compared to an open site. Agricultural and Forest Meteorology, 90, 141-156.

Neuhäusl, R., Dierschke, H. \& Barkman, J.J. (1982). Chorological phenomena in plant communities: Proceedings of 26th International Symposium of the International Association for Vegetation Science, Prague, Czech Republic.

Nieder, J., Engwald, S., Klawun, M. \& Barthlott, W. (2000). Spatial distribution of vascular epiphytes (including Hemiepiphytes) in a lowland Amazonian rain forest (Surumoni crane plot) of Southern Venezuela. Biotropica, 32(3), 385-396.

Ódor, P. \& van Hees, A.F.M., (2004). Preferences of dead wood inhabiting bryophytes for decay stage, log size and habitat types in Hungarian beech forests. Journal of Bryology, 26, 79-95. 
Ódor, P., Király, I., Tinya, F., Bortignon, F. \& Nascimbene, J. (2013). Patterns and drivers of species composition of epiphytic bryophytes and lichens in managed temperate forests. Forest Ecology and Management, 306, 256-265.

Økland, R. H. (1996). Are ordination and constrained ordination alternative or complementary strategies in general ecological studies? Journal of Vegetation Sciences, 7, 289-292.

Oksanen, J., Guillaume-Blanchet, F., Friendly, M., Kindt, R., Legendre, P., McGlinn, D., Minchin, P.R., O'Hara, R. B., Simpson, G.L., Solymos, P., Stevens, M.H.H., Szoecs, E. \& Wagner, H. (2016). vegan: Community Ecology Package. R package version 2.4-3. https://CRAN.R-project.org/package=vegan.

Orange, A., James, P.W. \& White, F.J. (2001). Microchemical methods for the identification of lichens. British Lichen Society. London. 101 pp.

Pach, M. \& Podlaski, R. (2015). Tree diameter structural diversity in Central European forests with Abies alba and Fagus sylvatica: managed versus unmanaged forest stands. Ecological Research, 30, 367-384.

Parker, G.G. (1995). Structure and microclimate of forest canopies. Eds. Forest Canopies: A review of research on a Biological Frontier. Academic Press, San Diego.

Ranius, T., Johansson, P., Niclas, B. \& Niklasson, M. (2008). The influence of tree age and microhabitat quality on the occurrence of crustose lichens associated with old oaks. Journal of Vegetation Science, 19, 653-662.

Schmidt, M., Kriebitzsch, W.-F. \& Ewald, J. (2011). Waldartenlisten der Farn- und Blütenpflanzen, Moose und Flechten Deutschlands, BfN Skript 299, Bonn.

Sillett, S.C. (1995). Branch epiphyte assemblages in the forest interior and on the clear-cut edge of a 700-year-old forest canopy in western Oregon. Bryologist, 98, 301-312.

Sillett, S.C. \& Rambo, T.R. (2000). Vertical distribution of dominant epiphytes in Douglas-Fir forests of the central Oregon cascades. Northwest Science, 74, $44-49$.

Sillett, S.C. \& Antoine, M.E. (2004). Lichens and bryophytes in forest canopies. In: Lowman, M.D., Rinker, H.B., (Eds). Forest canopies $2^{\text {nd }}$ Edition. Elsevier Academic Press, Oxford, 151-175.

Sipman, H.J.M. (1995). Preliminary review of the lichen biodiversity of the Colombian Montane Forests. In: Churchill, S.P., Balslev, H., Forero, E., Luteyn, J.L. (eds), 
Biodiversity and Conservation of Neotropical Montane Forests. New York Botanical Garden, New York, pp. 313-320.

Söderström, L., Urmi, E. \& Vána, J. (2002). Distribution of Hepaticae and Anthocerotae in Europe and Macaronesia. Lindbergia, 27, 3-47.

Tinya, F., Márialigeti, S., Király, I., Németh, B. \& Ódor, P. (2009). The effect of light conditions on herbs, bryophytes and seedlings of temperate mixed forests in Örség, Western Hungary. Plant Ecology, 204, 69-81.

van Herk, C.M. (1999). Mapping of ammonia pollution with epiphytic lichens in the Netherlands. Lichenologist, 31, 9-20.

van Herk, C.M. (2002). Epiphytes on wayside trees as an indicator of eutrophication in the Netherlands. In: Nimis, P.L., Scheidegger, C., Wolseley, P.A. (Eds.) Monitoring with Lichens - Monitoring Lichens, pp. 285-290. Dordrecht, Kluwer.

van Son, T. C., \& Halvorsen, R. (2014). Multiple parallel ordination and data manipulation: the importance of weighting species abundance data. Sommerfeltia, 37,1-37.

Vološčuk, I. (2014). Joint Slovak-Ukraine-Germany Beech Ecosystems as the World Natural Heritage. Ekologia, 33, 286-300.

Wiklund, K. \& Rydin, H. (2004). Ecophysiological constraints on spore establishment in bryophytes. Functional Ecology, 18, 907-913.

Wirth, V. (2010). Ökologische Zeigerwerte von Flechten - erweiterte und aktualisierte Fassung. Herzogia, 23, 229-248.

Wirth, V., Hauck, M., De Bruyn, U., Schiefelbein, U., John, V. \& Otte, V. (2009). Flechten aus Deutschland mit Verbreitungsschwerpunkt im Wald. Herzogia, 22, 79-107.

Wirth, V., Hauck, M. \& Schultz, M. (2013). Die Flechten Deutschlands. Eugen Ulmer Verlag, Stuttgart.

Zeleny, D. \& Schaffers, A.P. (2011). Too good to be true: pitfalls of using mean Ellenberg indicator values in vegetation analyses. Journal of Vegetation Science, 23, 419-431. 


\section{Chapter 5}

Synopsis 


\section{Synopsis}

The following sections summarize the main findings of the three studies about species richness differences in Fagus sylvatica primeval and production forests, the effects of natural forest dynamics on plant diversity and the changes of epiphytic cryptogam diversity and composition along a tree height gradient and integrate them in a broader context.

The present work is among the very few studies, especially in Europe, which compared plant diversity between production stands and true primeval forests without any known management legacy. Additionally, existing studies focused solely on vascular plants or epiphytic cryptogams (bryophytes and/or lichens). This thesis, however, deals with the impact of forest managementrelated disturbances on three systematic groups, i.e. vascular plants, bryophytes and lichens. Such studies are almost lacking. In addition to these comparative analyses between primeval and production forests or between different stages of primeval forests, there is only a limited number of studies that assess the diversity and composition of epiphytic bryophytes and lichens along the vertical gradient from the tree base to the crown.

The results of this thesis emphasize that forest management-related disturbance considerably affects overall plant species diversity and composition compared to untouched primeval forests. In addition, this study highlights the outstanding role of natural forest dynamics for plant and epiphyte species richness and reveals the importance of surveying epiphytes along the entire tree in the context of biodiversity studies.

\subsection{Impact of forest management-related disturbances on species diversity}

For vascular plants, $\alpha$-diversity was lower in the primeval forests, but rarefaction/extrapolation demonstrated a comparable richness ( $\gamma$-diversity) with the production stands (Chapter 2). A similar pattern was observed when comparing total plant species diversity of the initial, optimal and terminal stages with the corresponding production forests (Chapter 3). No significant differences in species richness were found between the three stages and the production forests. Though, vascular plant species richness in primeval forests still increases with increasing area contrasting to production stands. This clearly indicates that forest management-related disturbances do not increase vascular plant species richness in production forests compared to primeval forests. Various studies, especially in North America, compared the species diversity pattern between both forest types with mixed results. Forest floor species richness was found to be higher in old-growth than in production forests of the Pacific Northwest (Halpern \& Spies 
1995), which contradicted Scheller and Mladenoff (2002), who found the opposite in hardwood forests in northern Wisconsin and the Upper Peninsula of Michigan. Additional studies in temperate European managed forests and unmanaged forests with a distinct management legacy also produced mixed results. While Brunet et al. (1996) and Boch et al. (2013a) found a higher plant diversity in production forests, Graae and Heskjær (1997) could not detect any difference between forest types.

In contrast to vascular plants, cryptogam diversity was strongly affected by forest management in this study, indicating that epiphytes were much more susceptible to anthropogenic disturbance. Although the species numbers per plot ( $\alpha$-diversity) were on average only slightly higher (bryophytes) or even similar (lichens) between both forest types, rarefaction/extrapolation demonstrated a 30 and $100 \%$ higher bryophyte and lichen species richness ( $\gamma$-diversity) in primeval forests, respectively (Chapter 2 ). Even the initial stage in the primeval forests showed a distinctly higher cryptogam species richness (Chapter 3). These findings matched the results of studies in old-growth forests of North America (e.g. Lesica et al. 1991; Desponts et al. 2004) and unmanaged forests with a still detectable management background in Europe (e.g. Aude \& Poulsen 2000; Stokland \& Larsson 2011; Hofmeister et al. 2015). These results were mainly attributed to an increased number of specialist species (Hedenås \& Ericson 2003) replaced in production forests by generalists common to other disturbed areas.

While the species richness of various plant groups in tropical forests appears to be distinctly higher in primary compared to anthropogenic disturbed forests (e.g. Barthlott et al. 2001; Kessler et al. 2005; Barlow et al. 2007), this pattern does not seem to be fully transferable to boreal and temperate forests, at least for vascular plants. For this reason, if one returns to the question whether forest management increases plant diversity compared to untouched primeval forests, also species identity plays an essential role in addition to a potential management background of the unmanaged forests. Many studies reported that a higher vascular plant diversity in production forests was due to the immigration of shade-intolerant, highly competitive and ruderal species (Brunet et al. 1996; Decoq et al. 2004; Schmidt 2005). These species also occurred in the primeval forests studied here in a few naturally disturbed plots, with the consequence that plant diversity in the production stands did not exceed that of the primeval forests. On the contrary, an increasing dominance of disturbance-tolerant and nonforest plants favoured by forest management may lead to compositional changes (Scheller \& Mladenoff 2002) and to a substantial decrease in less competitive primeval forest species (Roberts \& Gilliam 1995; Battles et al. 2001). This may result in a long-term loss of total 
vascular plant species richness in production forests. For this reason, primeval forests are an essential conservation object and remaining fragments must be excluded from any kind of forest management in order to conserve the pristine plant diversity of boreal and temperate forests.

\subsection{Habitat heterogeneity and continuity promote species richness}

Natural disturbances favour habitat heterogeneity (Swanson et al. 2011) and in turn also species richness. However, forest management practices associated with intensive and short-rotation cycles reduce habitat diversity, which may result in a long-term loss of species diversity at landscape scales (Halpern \& Spies 1995). Primeval forests exposed to natural disturbance regimes are characterized by a greater habitat heterogeneity, i.e. higher substrate and microclimate variability (Crow et al. 2002; Larrieu et al. 2012) compared to more uniform production stands (Crist \& Veech 2006). In this study, the high habitat diversity was clearly evidenced by a generally higher species turnover of the forest floor and epiphyte vegetation between neighboring sampling units in the primeval forests compared to the production stands (Chapter 2). This suggested that the high $\beta$-diversity was the main determinant for the forest floor and epiphyte species richness at landscape level. This also explained the continuing increase of the vascular plant species richness with increasing area in the primeval forests, which was not detected in production stands. These findings indicate that natural and humaninduced disturbances completely differed in their ecological effects (Niemelä 1999).

In addition to habitat diversity, habitat continuity is another important factor for both vascular plant and cryptogam diversity (Fritz et al. 2008). This fact was clearly evidenced by the comparison of the epiphytic bryophyte and lichen diversity at a given stem diameter between primeval and production forests (Chapter 3). Trees occurring in primeval forests harboured a higher epiphyte species richness than stems of a comparable size in the production stands. This was attributed to the fact that trees with a similar stem diameter in both forest types differed in age. While trees in production forests rarely exceed 100 years, the maximum age detected in the primeval forests was over 400 years (R. Coventry, unpublished data). This highlights the essential role of tree age for epiphyte species richness by providing more time for colonization associated with increasing stem diameters and thus a higher microhabitat variability exposed to a diverse microclimate. 


\subsection{The role of natural forest dynamics for plant diversity and composition}

Natural forest dynamics affected the composition of the forest floor vegetation (Chapter 3), also reflecting the high species turnover in primeval forests (Chapter 2). Some species showed a strong preference to certain stages of the natural forest development. By contrast, total vascular plant species richness was not affected by natural forest development, as no significant difference was observed between the three forest development stages (Chapter 3). This was mainly attributed to the low variation in light conditions in multilayered primeval forests due to the small-scale patch structure. Gaps of smaller sizes $\left(<100 \mathrm{~m}^{2}\right)$ seemed to be more or less constantly present in the primeval forests studied here but were rapidly closed by lateral crown expansions. For this reason, light-driven increases of vascular plant diversity seemed not to be the rule in primeval forests and contrasted to findings in production forests (e.g. Kelemen et al. 2012). This corresponds to findings in a primeval Picea abies forest in central Germany (Dittrich et al. 2013).

In contrast, epiphytic bryophyte and lichen species richness on living trees and standing deadwood continuously increased from the initial to the terminal stage (Chapter 3). This was closely associated with tree age and tree size (Ódor \& van Hees 2004; Pach \& Podlaski 2015), as epiphyte species richness generally increases with stem diameter and tree age (Hauck 2011; Hofmeister et al. 2015) by providing more time for colonization and a high variability of microsites exposed to diverse microclimatic conditions. Additionally, marked changes of the epiphyte species composition were detectable revealing that most bryophytes ( $50 \%$ of 70 recorded species) and lichens ( $22 \%$ of 79 recorded species) preferred large stem diameters, whereas only two lichens and one bryophyte species apparently preferred thin and large stem diameters, respectively. Epiphyte numbers on downed deadwood were surprisingly not affected by natural forest development. This was due to the continuous availability of deadwood across all stages (Glatthorn et al. 2017) as a result of the high small-scale habitat heterogeneity in the primeval forests.

\subsection{Overlooked cryptogam diversity along the vertical tree gradient}

The results of this study show that sampling only the stem base $(0-2 \mathrm{~m})$ considerably underestimated the species richness of epiphytic cryptogams in Slovakian primeval forests. Additionally, the results demonstrated that sampling only the lowermost $2 \mathrm{~m}$ would cause a greater underestimation of the lichen than bryophyte species richness, accounting for 48 and 10 $\%$, respectively. Comparable studies conducted in the tropics (e.g. Goda-Sporn et al. 2010), in 
temperate forests of Tasmania (Jarman \& Kantvilas 1995) and North America (Hale 1952; McCune et al. 1997), and in Europe within forest stands and on trees of open habitats (Boch et al. 2013b; Fritz 2009; Kiebacher et al. 2016; Marmor et al. 2013) correspond to these findings, thus corroborating the robustness of our conclusion across different ecosystem types and environmental conditions.

The spatial vertical heterogeneity from the base of trees to the crown was characterized by distinct changes in microsite conditions, which influenced cryptogam species richness and composition. Epiphytic bryophytes and lichens indicated a darker and moister microclimate towards the stem base and an increase in acidity and nitrogen availability towards the crown. Bryophytes were concentrated at the stem base and represented by pleurocarpous, desiccationsensitive species, whereas desiccation-tolerant taxa were limited to higher stem segments with higher light intensity. In contrast to crustose lichens, which occurred throughout the entire stem, foliose and fruticose lichens dominated higher trunk areas. These findings were attributable to an increasing light intensity towards the canopy associated with increases in temperature. Several studies report that sun-exposed microsites often promote epiphytic lichen species richness in forests, as long as humidity does not become a limiting factor (Fritz et al. 2009, McCune et al. 1997, Ódor et al. 2013). For this reason, the stronger underestimation of total lichen than bryophyte species richness is attributable to the fact that bryophytes tended to be concentrated on the stem base due to moister conditions and lower light intensity. In contrast, lichens had their highest richness in the canopy. These findings also agree with results from other temperate forests of Europe and North America (Coote et al. 2008; Fritz 2009; McCune et al. 1997; Sillett 1995).

\subsection{Conclusion}

In summary, the results of this study clearly show that forest management practices considerably reduce overall plant species richness and strongly affect species composition in production forests compared to untouched primeval forests. Habitat continuity and heterogeneity drive species richness in primeval forests. Forest management practises with short rotation cycles and that suppress natural disturbance regimes in production forests markedly reduce species diversity compared to primeval forests. Our results also allow the conclusion that the differences in overall species richness between primeval and production forests are even higher than detected in the present study. Epiphytic bryophytes and lichens hidden in the tree crowns considerably increase the overall species diversity in primeval forests. 
Future comparative studies between both forest types should include at least some canopy sampling. These findings may reveal that forestry has an even more serious influence on cryptogam diversity than detected in the framework of this thesis. For this reason, the conservation of primeval forests is of prime importance in order to preserve and halt the loss of species diversity.

\section{References}

Aude, E. \& Poulsen, R.S. (2000). Influence of management on the species composition of epiphytic cryptogams in Danish Fagus forests. Applied Vegetation Science, 3(1), 81-88.

Battles, J.J., Shlisky, A.J., Barrett, R.H., Heald, R.C. \& Allen-Diaz, B.H. (2001). The effects of forest management on plant species diversity in a Sierran conifer forest. Forest Ecology and Management, 146(1-3), 211-222.

Boch, S., Prati, D., Müller, J., Socher, S., Baumbach, H., Buscot, F., ... Fischer, M. (2013a). High plant species richness indicates management-related disturbances rather than the conservation status of forests. Basic and Applied Ecology, 14(6), 496-505.

Boch S., Müller, J., Prati, D., Blaser, S. \& Fischer, M. (2013b). Up in the tree - the overlooked richness of bryophytes and lichens in tree crowns. PLoS One.

Brunet, J., Falkengren-Grerup, U. \& Tyler, G. (1996). Herb layer vegetation of south Swedish beech and oak forests - Effects of management and soil acidity during one decade. Forest Ecology and Management, 88, 259-272.

Coote, L., Smith, G.F., Kelly, D.L., O’Donoghue, S., Dowding, P., Iremonger, S. \& Mitchell, F.J.G. (2008). Epiphytes of Sitka spruce (Picea sitchensis) plantations in Ireland and the effects of open spaces. Biodiversity and Conservation, 16, 4009-4024.

Crist, T. O. \& Veech, J. A. (2006). Additive partitioning of rarefaction curves and species-area relationships: unifying $\alpha$-, $\beta$ - and $\gamma$-diversity with sample size and habitat area. Ecology Letters, 9(8), 923-932.

Crow, T.R., Buckley, D.S., Nauertz, E.A. \& Zasada, J.C. (2002). Effects of management on the composition and structure of northern hardwood forests in upper Michigan. Forest Science, 48, 129-145.

Decocq, G., Aubert, M., Dupont, F., Alard, D., Saguez, R., Wattez-Franger, A., ... Bardat, J. (2004). Plant diversity in a managed temperate deciduous forest: understorey response to 
two silvicultural systems: Plant diversity in managed forests. Journal of Applied Ecology, 41(6), 1065-1079.

Desponts, M., Brunet, G., Bélanger, L. \& Bouchard, M. (2004). The eastern boreal old-growth balsam fir forest: a distinct ecosystem. Canadian Journal of Botany, 82, 830-849.

Dittrich, S., Hauck, M., Jacob, M., Rommerskirchen, A. \& Leuschner, C. (2013). Response of ground vegetation and epiphyte diversity to natural age dynamics in a Central European mountain spruce forest. Journal of Vegetation Science, 24(4), 675-687.

Fritz, Ö., Gustafsson, L. \& Larsson, K. (2008). Does forest continuity matter in conservation? - A study of epiphytic lichens and bryophytes in beech forests of southern Sweden. Biological Conservation, 141, 655-668.

Fritz, Ö. (2009). Vertical distribution of epiphytic bryophytes and lichens emphasizes the importance of old beeches in conservation. Biodiversity and Conservation, 18, 289-304.

Fritz, Ö., Brunet, J. \& Caldiz, M. (2009). Interacting effects of tree characteristics on the occurrence of rare epiphytes in a Swedish beech forest area. The Bryologist, 112, 488505 .

Glatthorn, J., Feldmann, E., Pichler, V., Hauck, M. \& Leuschner, C. (2017). Biomass Stock and Productivity of Primeval and Production Beech Forests: Greater Canopy Structural Diversity Promotes Productivity. Ecosystems.

Goda-Sporn, S., Bos, M.M., Kessler, M. \& Gradstein, S.R. (2010). Vertical distribution of epiphytic bryophytes in an Indonesian rainforest. Biodiversity and Conservation, 19, 745760.

Graae, B.J. \& Heskjær, V.S. (1997). A comparison of understorey vegetation between untouched and managed deciduous forest in Denmark. Forest Ecology and Management, 96, 111-123.

Hale, M.E. (1952). Vertical distribution of cryptogams in a virgin forest in Wisconsin. Ecology, 33, 398-406.

Halpern, C.B. \& Spies, T.A. (1995). Plant species diversity in natural and managed forests of the Pacific Northwest. Ecological Applications, 5, 913-934.

Hauck, M. (2011). Site factors controlling epiphytic lichen abundance in northern coniferous forests. Flora, 206(2), 81-90. 
Hofmeister, J., Hošek, J., Holá, E. \& Novozámská, E. (2015). Decline in bryophyte diversity in predominant types of central European managed forests. Biodiversity and Conservation, 24(6), 1391-1402.

Jarman, S.J. \& Kantvilas, G. (1995). Epiphytes on an old Huon pine tree (Lagarostrobos franklinii) in Tasmanian rainforest. New Zealand Journal of Botany, 33, 65-78.

Kelemen, K., Mihók, B., Gálhidy, L. \& Standovár, T. (2012). Dynamic response of herbaceous vegetation to gap opening in a Central European beech stand. Silva Fennica, 46(1), 5365.

Kiebacher, T., Keller, C., Scheidegger, C \& Bergamini, A. (2016). Hidden crown jewels: the role of tree crowns for bryophyte and lichen species richness in sycamore maple wooded pastures. Biodiversity and Conservation, 25, 1605-1624.

Larrieu, L., Cabanettes, A. \& Delarue, A. (2012). Impact of silviculture on dead wood and on the distribution and frequency of tree microhabitats in montane beech-fir forests of the Pyrenees. European Journal of Forest Research, 131(3), 773-786.

Lesica, P. McCune, B., Cooper, S.V. \& Hong, W.S. (1991). Differences in lichen and bryophyte communities between old-growth and managed second-growth forests in the Swan Valley, Montana. Canadian Journal of Botany, 69, 1745-1755.

Marmor, L., Tõrra, T., Saag, L., Leppik, E. \& Randlane, T. (2013). Lichens on Picea abies and Pinus sylvestris - from the tree bottom to the top. Lichenologist, 45, 51-63.

McCune, B., Amsberry, K.A., Camacho, F.J., Clery, S., Cole, C., Emerson, C., Felder, G., French, P., Greene, D., Harris, R., Hutten, M., Larson, B., Lesko, M., Majors, S., Markwell, T., Parker, G.G., Pendergrass, K., Peterson, E.B., Peterson, E. T., Platt, J., Proctor, J., Rambo, T., Rosso, A., Shaw, D., Turner, R. \& Widmer, M. (1997). Vertical Profile of Epiphytes in a Pacific Northwest Old-growth Forest. Northwest Science, 71, 145-152.

Niemelä, J. (1999). Management in relation to disturbance in the boreal forest. Forest Ecology and Management, 115(2-3), 127-134.

Ódor, P. \& van Hees, A.F.M. (2004). Preferences of deadwood inhabiting bryophytes for decay stage, log size and habitat types in Hungarian beech forests. Journal of Bryology, 26, 7995. 
Ódor, P., Király, I., Tinya, F., Bortignon, F. \& Nascimbene, J. (2013). Patterns and drivers of species composition of epiphytic bryophytes and lichens in managed temperate forests. Forest Ecology and Management, 306, 256-265.

Pach, M. \& Podlaski, R. (2015). Tree diameter structural diversity in Central European forests with Abies alba and Fagus sylvatica: managed versus unmanaged forest stands. Ecological Research, 30(2), 367-384.

Roberts, M.R. \& Gilliam, F.S. (1995). Disturbance effects on herbaceous layer vegetation and soil nutrients in Populus forests of northern lower Michigan. Journal of Vegetation Science, 6(6), 903-912.

Scheller, R. M. \& Mladenoff, D. J. (2002). Understory Species Patterns and Diversity in OldGrowth and Managed Northern Hardwood Forests. Ecological Applications, 12, 13291343.

Schmidt, W. (2005). Herb layer species as indicators of biodiversity of managed and unmanaged forests. Forest Snow and Landscape Research, 79, 111-125.

Sillett, S.C. (1995). Branch epiphyte assemblages in the forest interior and on the clear-cut edge of a 700-year-old forest canopy in western Oregon. Bryologist, 98, 301-312.

Stokland, J.N. \& Larsson, K.-H. (2011). Legacies from natural forest dynamics: Different effects of forest management on wood-inhabiting fungi in pine and spruce forests. Forest Ecology and Management, 261(11), 1707-1721.

Swanson, M.E., Franklin, J.F., Beschta, R.L., Crisafulli, C.M., DellaSala, D.A., Hutto, R.L., ... Swanson, F.J. (2011). The forgotten stage of forest succession: early-successional ecosystems on forest sites. Frontiers in Ecology and the Environment, 9(2), 117-125. 


\section{Index of tables}

Table 1.1. Physiographic characteristics of the three primeval forest sites in eastern Slovakia. The conditions in the nearby production stands are very similar.

Table 2.1. Some physiographic characteristics of the three primeval forest sites in eastern Slovakia after Korpel (1995). The conditions in the nearby production forests are very similar.

Table 2.2. Mean bryophyte, lichen and vascular plant species numbers per $500 \mathrm{~m}^{2}$-plot $\pm \mathrm{SE}$ (minima and maxima in brackets) in the beech primeval forests in Havešová $(H)$, Kyjov (K) and Stužica (S), and the production forests in Havešová (HP), Kyjov (KP) and Stužica (SP). N = 40 plots in the primeval forests, 10 in the production forests.

Table A2.1. Stand properties of the production and primeval beech forests, Havešová $(H)$, Kyjov $(\mathrm{K})$ and Stužica $(\mathrm{S})$. Single letters = primeval forests; added 'P' = production forests; mean \pm standard error (minimum and maximum in brackets).

Table A2.2. Total species numbers occurring in each three primeval $(\mathrm{N}=40)$ plots and production forest $(\mathrm{N}=10$ plots).

Table 3.1. Physiographic characteristics of the three primeval forest sites in eastern Slovakia. The conditions in the nearby production forests (distance $<1 \mathrm{~km}$ ) are very similar.

Table 3.2. Mean plot-level species richness ( \pm standard error) of vascular plants on the ground, and epiphytic bryophytes and lichens on live trees and standing or downed deadwood in the initial, optimal, and terminal stages of the three primeval forests.

Table 3.3. Individual species preferences of the three forest development stages (initial, optimal and terminal stage) revealed by conducting canonical correspondence analysis (CCA) ordination for the forest floor vegetation (Fig. A3.1) and epiphytic bryophytes and lichens (Fig. A3.2).

Table 3.4. Results of an Indicator Species Analysis for epiphytic bryophytes and lichens on standing (live and dead, $N=1135)$ and downed trees $(N=158)$ of different diameter classes; only species with significant results are shown.

Table A3.1. Absolute number $(N)$ and percentage (\%) of plots assigned to one of the three development stages (initial, optimal or terminal) within the primeval forests and the corresponding production stands in the three study areas (Havešová, Kyjov and Stužica).

Table A3.2. Stand properties of the forest development stages (initial, optimal, terminal) in the primeval forests of the three study areas (Havešová, Kyjov and Stužica).

Table A3.3. Stand properties of the forest development stages (initial. optimal. and terminal stages) in the primeval forests and the production forests (means of the three study areas).

Table A3.4. Vascular plants, bryophytes and lichens (plus three non-lichenized fungi marked with '*') occurring in the three primeval ( $\mathrm{N}=120$ plots) and production ( $\mathrm{N}=30$ plots) forests Havešová, Kyjov and Stužica. 
Table 4.1. Total number (N) of sampled segments of the height classes $\mathrm{S} 1$ to $\mathrm{S} 13$ and crown areas (IC, OC) in Havešová forest, and the total number of bryophyte and lichen species found in each segment and crown area.

Table A4.1. Species list including abbreviations for NMDS ordination, the occurrences below and above two meters, the crown area (CA: inner and outer crown) and the rel. frequency $(\%)$ based on the occurrences on the total number of trees $(\mathrm{N}=57)$.

Table A4.2 Ellenberg Indicator Values (EIV) light (L), temperature (T), moisture (F), reaction (R) and nitrogen $(\mathrm{N})$ for epiphytic bryophytes (values after Berg 2010; definition after Hill et al. 2007; for temperature: definition after Wirth et al. 2010).

Table A4.3. Ellenberg Indicator values (EIV) light (L), temperature (T), moisture (F), reaction $(\mathrm{R})$ and nitrogen $(\mathrm{N})$ for epiphytic lichens (values and definition after Wirth et al. 2010). 


\section{Index of figures}

Figure 1.1. Location of the three study sites Havesova, Kyjov and Stuzica in the western Carpathian Mountains, eastern Slovakia.

Figure 1.2. Scheme illustrating the sampling design (Chapter 4) applied for the assessment of epiphytic bryophytes and lichens on beech trees with up to 13 segments of each $2 \mathrm{~m}$ length. IC and OC stand for the inner and outer crown.

Figure 2.1. Location of the three study areas in eastern Slovakia.

Figure 2.2. Rarefaction/extrapolation curves for epiphytic bryophytes (a), lichens (b) and vascular plants (c) in the primeval and production forests. The species numbers of the three study areas (Havešová, Kyjov and Stužica) were added (y-axes have different scaling). Confidence intervals are shaded. Note the different number of plots in the production $(\mathrm{N}=30)$ and primeval forests $(\mathrm{N}=120)$. 'Dashed' line $=$ extrapolation; 'solid' line = interpolation. 'Triangle' and 'circle' denote primeval and production forest, respectively.

Figure 2.3. $\beta$-diversity (Sørensen Dissimilarity Index) of the epiphytic bryophyte (first row), lichen (second row) and vascular plant communities (third row) of each five plotpairs of the three primeval forests Havešová $(H)$, Kyjov $(K)$ and Stužica $(S)$ and the three corresponding production stands ( single letters = primeval forests; added ' $\mathrm{P}$ ' = production forests). The distances in the plot pairs were the same for production and primeval forests. Also given is the mean $\beta$-diversity of all primeval and production forest plots pooled (box-whisker-plots with median, 25- and 75-percentiles and extremes). Note different scaling of y-axes. Different small letters indicate significant differences in mean $\beta$-diversity between each primeval and production forest (ANOVA: $\mathrm{P} \leq 0.05$, Kruskal-Wallis test; $\mathrm{P} \leq 0.05$ ). Different capital letters indicate significant differences in mean $\beta$-diversity between primeval and production forests.

Figure 2.4. NMDS of the epiphytic bryophyte, lichen and vascular plant communities in the study areas, Havešová $(H)$, Kyjov $(\mathrm{K})$ and Stužica $(\mathrm{S})$ (single letters= primeval Forest; added ' $\mathrm{P}$ '= production Forest, added ' $\mathrm{S}$ '= vegetation survey in spring). (a) Bryophytes. Mean stress in real data: Axis 1 46.614, Axis 2 26.760. (b) Lichens. Mean stress in real data: Axis 1 47.608, Axis 2 28.979. (c) Vascular plants. Mean stress in real data: Axis 1 48.099, Axis 24.197.

Figure A2.1. Rarefaction/Extrapolation Curves of bryophytes (first column), lichens (second column) and vascular plants (third column) in primeval and production forests of Havešová (first row), Kyjov (second row) and Stužica (third row). Primeval forests, $\mathrm{N}=40$ plots, production forests, $\mathrm{N}=10$ plots. Confidence intervals are shaded. 'Dashed' line=Extrapolation; 'solid' line=Interpolation. 'Triangle' and 'circle' denote primeval and production forest, respectively.

Figure A2.2. Rarefaction/extrapolation curves (left column) and sample-completeness curves (right column) for bryophytes (first row), lichens (second row) and vascular plants (third row) in the primeval and production forests. The species numbers and the sample-completeness of the three study areas (Havešová, Kyjov and Stužica) were 
added (y-axes have different scaling in case of the sample-completeness curves). Confidence intervals are shaded. The number of plots was extrapolated to the doubled reference sample size $(\mathrm{N}=60)$. Nboot $=1000$. 'Dashed' line = extrapolation; 'solid' line = interpolation. 'Triangle' and 'circle' denote primeval and production forest, respectively. Statistics: Kruskal-Wallis test, * $\mathrm{P} \leq 0.05$, ** $\mathrm{P} \leq 0.01$, *** $\mathrm{P} \leq 0.001$.

Figure A2.3. Rarefaction/extrapolation curves of bryophytes (left column), lichens (middle column) and vascular plants (right column) in primeval and production forests of Havešová (first row), Kyjov (second row) and Stužica (third row). Primeval forests, $\mathrm{N}=20$ plots, production forests, $\mathrm{N}=10$ plots (extrapolated to the doubled reference sample size). Confidence intervals are shaded. Nboot $=1000$. 'Dashed' line $=$ extrapolation; 'solid' line = interpolation. 'Triangle' and 'circle' denote primeval and production forest, respectively. ${ }^{1}$ Statistics: ANOVA, * $\mathrm{P} \leq 0.05$, ** $\mathrm{P} \leq 0.01$, *** $\mathrm{P} \leq 0.001$. ${ }^{2}$ Statistics: Kruskal-Wallis test, $* \mathrm{P} \leq 0.05$, ** $\mathrm{P} \leq 0.01, * * * \quad \mathrm{P} \leq 0.001$. ${ }^{3}$ Statistics: Welch's F-Test, * $\mathrm{P} \leq 0.05$, ** $\mathrm{P} \leq 0.01$, *** $\mathrm{P} \leq 0.001$

Figure A2.4. Sample-completeness curves of epiphytic bryophytes (left column), lichens (middle column) and vascular plants (right column) in primeval and production forests of Havešová (first row), Kyjov (second row) and Stužica (third row). Primeval forests, $\mathrm{N}=20$ plots, production forests, $\mathrm{N}=10$ plots (extrapolated to the doubled reference sample size). Confidence intervals are shaded. Nboot $=1000$. 'Dashed' line = extrapolation; 'solid' line = interpolation. 'Triangle' and 'circle' denote primeval and production forest, respectively. Statistics: Kruskal-Wallis test, $* \mathrm{P} \leq 0.05$, ** $\mathrm{P} \leq 0.01, * * * \mathrm{P} \leq 0.001$.

Figure A2.5. Rarefaction/extrapolation and sample-completeness curves of deadwood bryophytes and lichens in primeval and production forests (Havešová, Kyjov and Stužica). Total number of plots: primeval forests, $\mathrm{N}=65$; production forests, $\mathrm{N}=5$ (only plots with deadwood occurrence were included). Sample size was fixed to the doubled reference sample size $\mathrm{N}=10$. Confidence intervals are shaded. Nboot $=1000$. 'Dashed' line = extrapolation; 'solid' line = interpolation. 'Triangle' and 'circle' denote primeval and production forest, respectively. Statistics: Kruskal-Wallis test, $* \mathrm{P} \leq 0.05, * * \mathrm{P} \leq 0.01, * * * \mathrm{P} \leq 0.001$

Figure 3.1. Location of the three study sites Kyjov, Havešová, and Stužica in the Carpathian Mountains of eastern Slovakia.

Figure 3.2. Rarefaction (solid line)/extrapolation (dashed line) curves for the richness of epiphytic bryophytes (a) and lichens (b), and herb layer vascular plants (c) occurring in plots assigned to the initial $(N=44)$, optimal $(N=35)$ or terminal stages $(N=41)$ of the primeval forests, and the corresponding production forests $(N=30)$. The vertical dot-dashed line represents the reference sample size $(N=35)$. Confidence intervals are shaded. Pooled data from the three primeval and production forests.

Figure 3.3. Relationship between bryophyte and lichen species richness and stem diameter in the (a) primeval and (b) production forests according to a GLM analysis. Regression lines (dashed) and confidence intervals (shaded) represent the estimated values for 
the population mean. Symbols characterize the species richness of bryophytes and lichens at a given dbh. Total number of sampled trees in the primeval forests: bryophytes $\mathrm{N}=1026$, lichens $\mathrm{N}=925$; in the production forests: bryophytes $\mathrm{N}=401$, lichens $\mathrm{N}=398$.

Figure A3.1. CCA biplots showing the association between sample plots $(N=120)$ assigned to the three forest development stages (initial [ini], optimal [opt], terminal[ter]) and the cover values of 64 herb layer species occurring in the primeval forests. Biplot (a) shows the location of the 120 plots and 64 species, with the species names written in biplot (b). For abbreviation of species names see Table A3.4. Eigenvalues: 0.05 (axis 1) and 0.04 (axis 2).

Figure A3.2. CCA biplots showing the association between sample plots $(N=120)$ assigned to the three forest development stages (initial [ini], optimal [opt], terminal[ter]) and the presence of $(\mathbf{a}, \mathbf{b})$ epiphytic bryophytes and $(\mathbf{c}, \mathbf{d})$ lichens occurring in three primeval forests. Biplots (a) and (c) show the location of the 120 plots and epiphyte species, with the species names written in biplots (b) and (d). Circles indicate plots $(N=120)$, diamonds bryophyte or lichen species. For abbreviations of species names see Table A3.4. Bryophytes: eigenvalues 0.05 (axis 1), 0.02 (axis 2); lichens: eigenvalues 0.06 (axis 1), 0.05 (axis 2).

Figure 4.1. Location of the primeval forest Havešová in the Carpathians, Slovakia. The map in the middle shows the extension of the windthrow with the grid (grey vertical and horizontal lines) and the ten randomly selected sampling units (black plots with letters from A-J). The grey line to the south of the windthrow-affected area represents the reserve border. The southernmost plots $(\mathrm{E} \& \mathrm{~J})$ are located at least 60 meters from the reserve border.

Figure 4.2. Scheme illustrating the sampling design applied for the assessment of epiphytic bryophytes and lichens on beech trees with up to 13 segments of each $2 \mathrm{~m}$ length. IC and OC stand for the inner and outer crown.

Figure 4.3. Variation of the mean bryophyte (a) and lichen (b) species numbers along the vertical gradient. The letters within (a) and (b) derive from the Tukey test after conducting the second models, in which we treated the segments and crown area as a 13-level factor. Equal letters indicate no significant differences between the segments and the crown area with regard to species richness. Black dots and vertical lines characterize the mean and standard deviation, respectively. S1-S11 indicate each $2 \mathrm{~m}$ segment, IC and OC the inner and outer crown area.

Figure. 4.4. GNMDS ordination in (a) provides the compositional differences between the segments (S1-S11), the inner and outer crown (IC and OC) and the preferences of the main bryophyte (AM=acrocarpous, $\mathrm{PM}=$ pleurocarpous mosses, $\mathrm{LW}=$ liverworts) and lichen groups $(\mathrm{CL}=$ crustose, $\mathrm{FL}=$ foliose, $\mathrm{SL}=$ shrub [fruticose] lichens). Stress: 0.05. GNMDS ordinations in (b) and (c) demonstrate compositional differences along the height gradient with regard to the individual bryophyte and lichen species, Stress: 0.04. The two plots ( $b$ and c) were separated for a better illustration. Mean Ellenberg indicator values light $(\mathrm{L})$, humidity $(\mathrm{R})$, acidity $(\mathrm{R})$ and nitrogen 
availability (N) were overlaid in (a) and (b) for interpretation of the ecological gradient. The first two axes are shown (a-c). For abbreviations of species names (c) see Table A4.1.

Figure 4.5. Mean Ellenberg indicator values (EIV) light (L), moisture (F), acidity (R) and nitrogen availability $(\mathrm{N})$ for the epiphyte communities in the segments $\mathrm{S} 1$ to S11 and the crown (IC, OC) calculated from the presence of bryophytes and lichens (box plots with arithmetic mean, 25 and 75-percentiles and maxima and minima). Statistics: Kruskal-Wallis test and additional testing with Dunn`s test for multiple comparisons for mean EIVs. Means with equal letters do not differ significantly. Outliers are not shown.

Figure A4.1. Impressions of the windthrow in 2014 in Havešová.

Figure A4.2. Uprooted trees caused by the storm event in 2014.

Figure A4.3. One of the plots, where epiphytic cryptogams were detected along the trees.

Figure A4.4. Impressions of the windthrow in 2014 in Havešová. A few trees are still standing.

Figure A4.5. Aggregation of individual species to one of the main groups illustrated with acrocarpous (AM) and pleurocarpous mosses (PM). Bold numbers in brackets indicate the presence of the individual species (left side of the tree) and the resulting abundance of the main groups (AM and PM; right side of the tree), respectively. 'S1' characterizes the lowermost segment from 0-2 m, IC and OC the inner and outer crown, respectively. For illustration purpose, only shown for $\mathrm{S} 1$.

Figure A4.6. The calculation (formula) of the 'main group' abundances are provided for a better understanding. Bold numbers indicate each $2 \mathrm{~m}$ segment along the stem, IC and $\mathrm{OC}$ the inner and outer crown, respectively. Red numbers represent the abundance of the main groups (only shown from S1-S4 for illustration purpose).

Figure A4.7. The calculation (formula) of the 'individual species' abundances are provided for a better understanding. Bold numbers indicate each $2 \mathrm{~m}$ segment along the stem, IC and $\mathrm{OC}$ the inner and outer crown, respectively. Red numbers represent the presence/absence of the individual species (only shown from S1-S4 for illustration purpose).

Figure A4.8. Vertical distribution of each bryophyte species along the entire tree. Each segment stands for a height of two meters.

Figure A4.9. Vertical distribution of each lichen species along the entire tree. Each segment stands for a height of two meters. 


\section{Acknowledgments}

Completing this thesis would not have been possible without the help of so many people. In particular, special thanks go to my supervisors Christoph Leuschner and Markus Hauck for providing the opportunity to conduct this $\mathrm{PhD}$ on this very interesting topic, and for providing support during the last years. Besides, it was a pleasure for me to spend more than two years of fieldwork in Slovakia together with my colleagues Eike Feldmann and Jonas Glatthorn. Slovakia would not have been the same without these two guys.

Furthermore, I would like to thank all my colleagues from the department, especially Fabian Brambach, Agnes Förster, Martyna Kotowska, Jürgen Homeier, Stefan Meyer and Laura Sutcliffe for countless helpful discussions in scientific questions (not only!). Additionally, I also want to thank Yasmin Abou Rajab, Sarah Burns, Daisy Cárate, Torben Lübbe and Bettina Wagner, who also became very good friends. Not to forget all our technical assistants for providing support for laboratory work.

And, finally, my biggest thanks go to my parents and my family: thank you for being there for me any time! 


\section{Publications}

Kaufmann, S., Hauck, M. \& Leuschner, C. (Accepted). Change in species richness and composition of epiphytic cryptogams along a height gradient in a Fagus sylvatica primeval forest.

Journal of Vegetation Science

Kaufmann, S., Hauck, M. \& Leuschner, C. (2018). Effects of natural forest dynamics on vascular plant, bryophyte, and lichen diversity in primeval Fagus sylvatica forests and comparison with production forests.

Journal of Ecology

Kaufmann, S., Hauck, M. \& Leuschner, C. (2017). Comparing the plant diversity of paired beech primeval and production forests: Management reduces cryptogam, but not vascular plant species richness.

Forest Ecology and Management

\section{Presentations}

Kaufmann, S. \& Berg, C. (2012). Nature conservation relevance of Bryophytes in TNFP, Cyprus. European Committee for Conservation of Bryophytes, Budapest, Hungary

Kaufmann, S., Hauck, M. \& Leuschner, C. (2015). Managed vs. Unmanaged forests - The importance of Slovakian primeval beech forests for species diversity and red listed vascular plants, bryophytes and lichens in contrast to managed forests. Interdisziplinäres WissenschaftlerInnentreffen im Rahmen des Übereinkommens über die biologische Vielfalt auf der Insel, Vilm, Germany

Kaufmann, S., Hauck, M. \& Leuschner, C. (2016). The importance of Slovakian primeval beech forests in the western Carpathian Mountains for bryophyte diversity in contrast to managed forests. European Committee for Conservation of Bryophytes, Montenegro

Kaufmann, S., Hauck, M. \& Leuschner, C. (2016). Heterogene Waldstrukturen führen zu einem Anstieg der Artenvielfalt - Vergleich der Phytodiversität slowakischer Buchenurwälder mit Wirtschaftswäldern. Forstwissenschaftliche Tagung (FoWiTa), Freiburg, Germany

Kaufmann, S., Hauck, M. \& Leuschner, C. (2018). Effects of natural forest dynamics on bryophyte and lichen diversity in primeval beech forests and comparison with production forests. 50 Jahre Bryologische und Lichenologische Arbeitsgemeinschaft für Mitteleurope - Erforschung und Schutz von Moosen und Flechten in Mitteleuropa, Frankfurt, Germany 


\section{EIDESSTATTLICHE ERKLÄRUNG}

Vor- und Zuname: Stefan Kaufmann

Geburtsort: $\quad$ Leoben, Österreich

Hiermit versichere ich an Eides statt,

dass ich die eingereichte Dissertation selbständig und ohne unzulässige fremde Hilfe verfasst, andere als die in ihr angegebene Literatur nicht benutzt und dass ich alle ganz oder annähernd übernommenen Textstellen sowie verwendete Grafiken, Tabellen und Auswertungsprogramme kenntlich gemacht habe. Außerdem versichere ich, dass die vorgelegte elektronische mit der schriftlichen Version der Dissertation übereinstimmt und die Abhandlung in dieser oder ähnlicher Form noch nicht anderweitig als Promotionsleistung vorgelegt und bewertet wurde.

Unterschrift

Ort, Datum 